\title{
U-Pb Detrital Zircon Geochronology within the Cape Fold BeltKaroo Basin System
}

Justin Raymond Dean

Follow this and additional works at: https://researchrepository.wvu.edu/etd

\section{Recommended Citation}

Dean, Justin Raymond, "U-Pb Detrital Zircon Geochronology within the Cape Fold BeltKaroo Basin System" (2014). Graduate Theses, Dissertations, and Problem Reports. 5456.

https://researchrepository.wvu.edu/etd/5456

This Thesis is protected by copyright and/or related rights. It has been brought to you by the The Research Repository @ WVU with permission from the rights-holder(s). You are free to use this Thesis in any way that is permitted by the copyright and related rights legislation that applies to your use. For other uses you must obtain permission from the rights-holder(s) directly, unless additional rights are indicated by a Creative Commons license in the record and/ or on the work itself. This Thesis has been accepted for inclusion in WVU Graduate Theses, Dissertations, and Problem Reports collection by an authorized administrator of The Research Repository @ WVU. For more information, please contact researchrepository@mail.wvu.edu. 


\title{
U-Pb Detrital Zircon Geochronology within the Cape Fold Belt/Karoo Basin System
}

\author{
Justin Raymond Dean \\ Thesis submitted \\ to the Eberly College of Arts and \\ Sciences at West Virginia University \\ in partial fulfillment of the requirements for the degree of \\ Masters of Science \\ in Geology \\ Amy Weislogel, Ph. D., Chair \\ Kathleen Benison, Ph.D. \\ Ryan Shackleton, Ph. D. \\ Department of Geology and Geography
}

Morgantown, West Virginia

2014

Keywords: Karoo Basin, Cape Fold Belt, Ecca Group, Beaufort Group, U-Pb Detrital Zircon Geochronology, Gondwanide Orogeny, Panthalassan margin

Copyright 2014 Justin Raymond Dean 


\title{
ABSTRACT \\ U-Pb Detrital Zircon Geochronology of the Cape Fold Belt/ Karoo Basin System
}

\author{
Justin Raymond Dean
}

$\mathrm{U}-\mathrm{Pb}$ detrital zircon geochronology, in addition to sandstone petrography and heavy mineral analysis are used to constrain the provenance of the Ecca and Beaufort lithologic Groups within the Tanqua, Laingsburg, and Ripon sub-basins of the southern Gondwanan Karoo Basin. Zircon ages were acquired using Laser Ablation-Inductively Coupled PlasmaMass Spectrometry (LA-ICP-MS) on 553 grains from seven hand samples. Results show two major age populations exist in all samples including an abrupt 245-295 Ma population and a broad 350-750 Ma population. Other minor age populations are present between 300-350 Ma, 850-1200 Ma, and > $2000 \mathrm{Ma}$ in some samples. These age populations coincide with the age of regional source terranes and tectonic events which consist of: Gondwanide (southern magmatic arc: 245-290 Ma), Pan African (488-1100 Ma), and Pampean (525-550 Ma) Orogenies as well as the Cape Supergroup (400-2700 Ma), Dwyka Glacial Group (500-3500 Ma), North Patagonian Massif (235-580 Ma), Deseado Massif (344-521 Ma), Namaqua-Natal Province (800-2200 Ma), and the Kaapvaal/Kalahari Craton (> $1800 \mathrm{Ma})$.

$\mathrm{U}-\mathrm{Pb}$ zircon ages within the Tanqua, Laingsburg, and Ripon sub-basins are relatively uniform throughout the middle to upper Ecca Group succession. Middle Ecca Group zircon samples contains the same major age populations as other samples, however, the proportion of Permian zircons are more prevalent than samples collected in the Upper Ecca and Beaufort Groups whereas $>1000$ Ma zircon are rare and only exist as either minor populations or single grains. The Cambrian to Neoproterozoic age population also varies within samples with an overall increase in grain abundance upwards into the Beaufort Group.

The CFB-Karoo basin has been identified as a fold-thrust belt/foreland basin system; however, the Karoo basin sediment composition is inconsistent with derivation from the foldbelt leading to the hypothesis that the fold-belt may not have existed during Karoo basin development (300-250 Ma). Thin-section petrography of 18 sandstone samples does not fully support some previously proposed paleogeographic models. All analyzed samples generally lie in the mixed affinity and dissected arc QmFLt diagram fields. This is interpreted to indicate that the Karoo basin fill was sourced by multiple eroding source terranes causing data to plot as a mixture of multiple contributing sediment sources.

In order to further understand sediment distribution within the Tanqua, Laingsburg and, Ripon sub-basins based on north-northeast Permian paleocurrent indicators acquired from previous studies and paleogeographic reconstruction, two primary sediment pathways were hypothesized. The Ceres syntaxis, which separates the N-S and E-W trending branches, may serve as a sediment pathway connecting the hinterland and the main depocenter within the Karoo basin The formation of the Ceres syntaxis is likely responsible for the formation of and deposition into the Tanqua and Laingsburg sub-basins. The other sediment pathway, the Port Elizabeth antitaxis, may be associated with convergence of the Deseado Massif and southern Gondwanna and later associate with the Gulhas-Falkland fracture zone. The formation of this 
antitaxis was likely responsible for routing sediment into the Karoo Basin. The north-northeast paleocurrent direction also allows northern source terranes surrounding the Kalahari Craton can be eliminated as potential primary sediment sources, therefore grains matching the age of Kalahari Craton rocks that are found in Karoo basin-fill were likely the result of erosional recycling of the Cape Supergroup. 


\section{Acknowledgments}

I would like to thank my advisor, Dr. Amy Weislogel, for the opportunity to work on such a unique project and for her endless guidance throughout my time at West Virginia University. I would like to thank my graduate committee, Ryan Shackleton and Kathleen Benison for their support. I would also like to thank Dr. Jaime Toro for his extensive assistance with data collection. This project would have been impossible without the collaboration and personal comments from fellow classmate Matt McKay. I would also like to that Dr. Jeremy Hourigan (University of California Santa Cruz) and Dr. George Gehrels (University of Arizona Department of Geosciences) for the use of their analytical facilities. Lastly I would like to thank my family for their unconditional support during my graduate career. 


\section{Table of Contents}

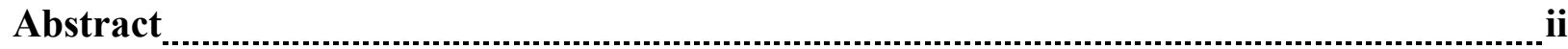

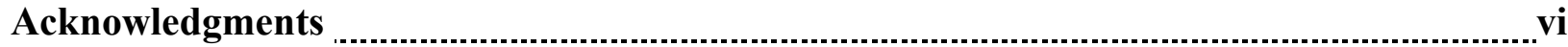

List of Figures

List of Tables

Chapter I: Introduction ............................................................................................................ 1

1.1 Sediment Origin .................................................................................................................... 1

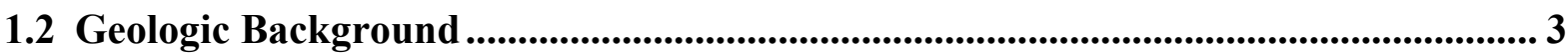

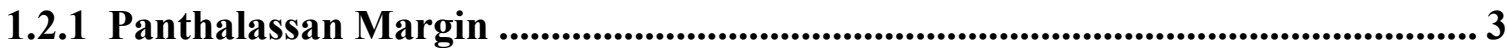

1.2.2 Karoo Basin: Structure and Stratigraphy ......................................................... 5

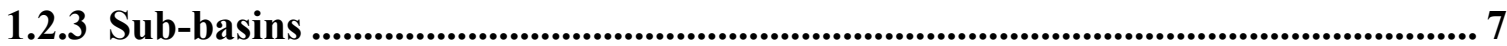

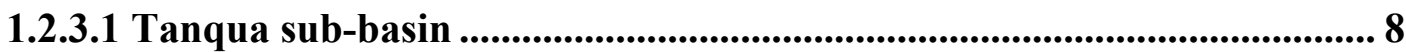

1.2.3.2 Laingsburg sub-basin .............................................................................. 10

1.2.3.3 Ripon sub-basin ................................................................................... 12

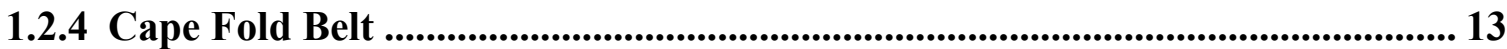

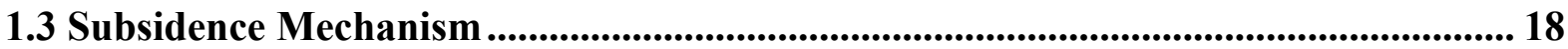

1.3.1 Flexural Subsidence ........................................................................................ 18

1.3.2 Mantle Driven Dynamic Subsidence ................................................................. 21

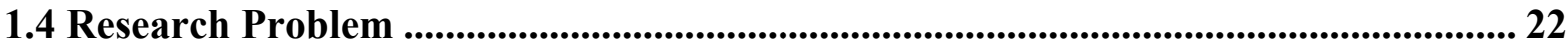

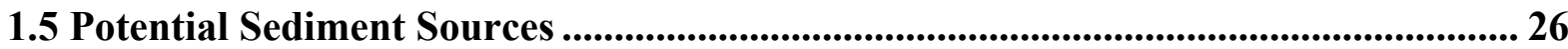

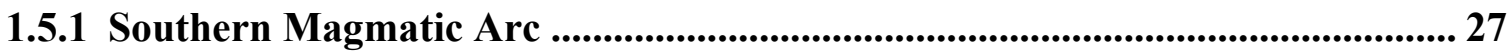

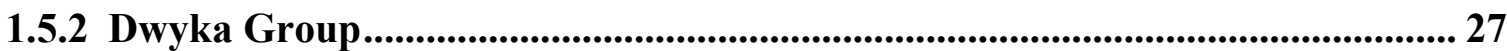

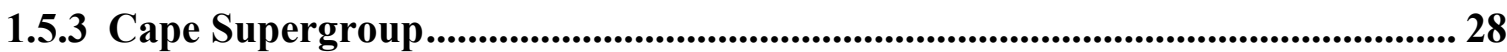

1.5.4 Saldania Belt and Gariep Belt ........................................................................... 30

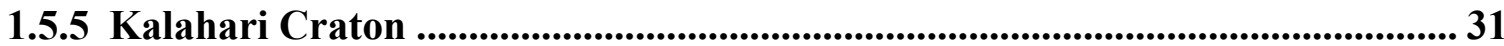

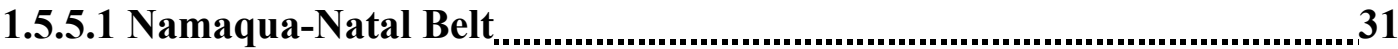

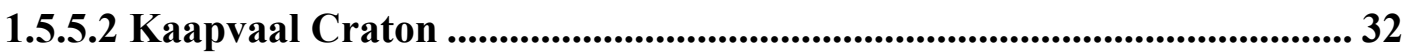

1.5.6 Patagonian and other South American Source Terranes...................................... 32

Chapter II: Methodology .................................................................................................................... 35

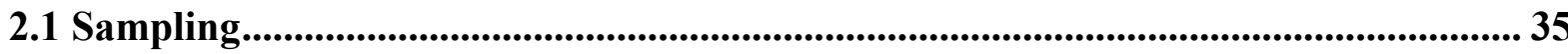

2.2 U-Pb Detrital Zircon Geochronology ................................................................................ 39

2.2.1 Maximum Depositional Age ............................................................................................ 43 
2.2.2 Kolmogorov-Smirnoff Test....................................................................................... 44

2.3 Sandstone Petrography ................................................................................................. 45

2.4 Heavy Mineral Analysis........................................................................................................ 46

Chapter III: Results......................................................................................................................... 46

3.1 U-Pb Sample Descriptions and Age Populations.............................................................. 46

3.1.1 Sample 12ZA13: Waterford Formation .................................................................. 53

3.1.2 Sample 12ZA26: Laingsburg Formation ................................................................. 54

3.1.3 Sample 09-BL-C1: Laingsburg Formation ........................................................... 59

3.1.4 Sample 13ZA91: Waterford Formation ................................................................. 64

3.1.5 Sample 13ZA93: Beaufort Group .............................................................................. 70

3.1.6 Sample 13ZA68: Ripon Formation....................................................................... 76

3.1.7 Sample 13ZA74: Waterford Formation ................................................................. 81

3.2 U-Pb Age Population Correlation.............................................................................. 85

3.3 Kolmogorov-Smirnoff Test.............................................................................................. 88

3.4 Maximum Depositional Ages........................................................................................... 90

3.5 Metamorphic Versus Igneous Zircon .......................................................................... 93

3.6 Tanqua Sub-basin Sample Overview .............................................................................. 97

3.7 Laingsburg Sub-basin Sample Overview..................................................................... 97

3.8 Ripon Sub-basin Sample Overview ................................................................................ 98

3.9 Permo-Triassic Karoo Sandstone Composition ................................................................ 99

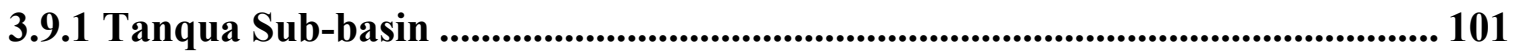

3.9.2 Laingsburg Sub-basin ...................................................................................... 102

3.9.3 Ripon Sub-basin .................................................................................................. 107

3.10 Heavy Mineral Analysis ........................................................................................... 112

3.10.1 Tanqua Sub-basin Heavy Minerals Sample ....................................................... 112

3.10.2 Laingsburg Sub-basin Heavy Minerals Samples.................................................. 112

3.10.3 Ripon Sub-basin Heavy Minerals Samples.......................................................... 113

3.10.4 Evolution of Heavy Mineral Abundances .......................................................... 114

Chapter IV: Discussion ....................................................................................................................... 118

4.1 Potential Source Sediments for the Ecca and Beaufort Groups within the Tanqua,

Laingsburg and Ripon Sub-basins .............................................................................. 118

4.1.1 Permian-Triassic Population .................................................................................... 120

4.1.2 Neoproterozoic-Devonian Population................................................................... 121

4.1.3 Carboniferous and Paleoproterozoic-Mesoproterozoic Populations............... 124

4.2 Zircon Source Comparison .................................................................................................. 126 
4.3 KDE Versus Probability Density Plots........................................................................... 128

4.5 Geospatial Trends of the Ecca and Beaufort Sandstone Compositions .................... 128

4.5.1 Ripon Sub-basin ................................................................................................. 130

4.5.2 Laingsburg Sub-basin ......................................................................................... 134

4.5.3 Tanqua Sub-basin.............................................................................................. 136

4.6 Heavy Mineral Abundance Trends ............................................................................ 138

4.7 Sediment Pathways ............................................................................................................. 138

4.7.1 Ceres syntaxis .............................................................................................................. 138

4.7.2 Port Elizabeth Anti-taxis ............................................................................................ 139

4.8 Detrital Versus Airfall Ash Ages: Laingsburg Sub-basin ........................................... 140

4.9 Karoo basin Model................................................................................................................ 142

Chapter V: Conclusions .............................................................................................................. 144

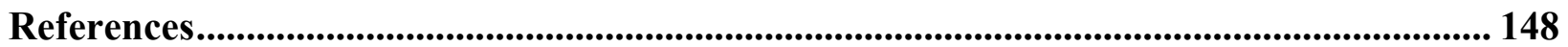

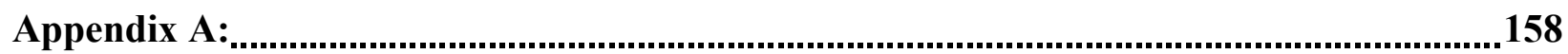

Appendix B: Ecca/Beaufort Sandstone Composition ................................................................ 168 


\section{List of Figures}

Figure 1: Gondwana Paleogeographic reconstruction ..........................................................5

Figure 2: Simplified geologic map of the Cape Fold Belt and Karoo Basin .................................. 7

Figure 3: Generalized stratigraphic column of the Cape and Karoo Supergroups ........................8

Figure 4: Generalized composite stratigraphic column of the Karoo Supergroup in the Tanqua sub-basin

Figure 5: Generalized stratigraphic column of the Cape and Karoo Supergroups and the underlying Pre-Cambrian basement

Figure 6: Generalized composite stratigraphic column of the Karoo Supergroup in the Ripon sub-basin $\quad 12$

Figure 7: Cape Supergroup geologic map ........................................................................16

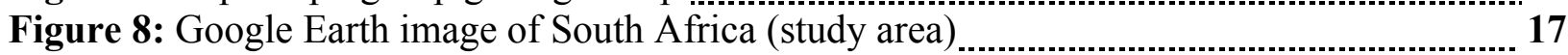

Figure 9: Stratigraphic cross section of Karoo basin strata displaying the South to Northeast thickness relationship.

Figure 10: Schematic representation of Karoo basin evolution from the Early Carboniferous to Late Triassic ........................................................................................ 2

Figure 11: Schematic representation of mantle driven dynamic subsidence ...........................21

Figure 12: Normalized relative probability density plots of published Dwyka Glacial Group samples

Figure 13: Relative probability density diagrams of Cape Supergroup detrital zircons .............29

Figure 14: Relative probability density diagram of Namaqua-Natal zircons with tectonic events

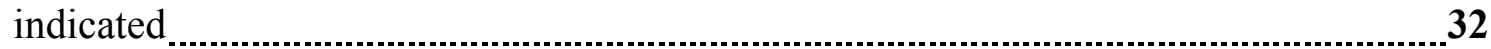

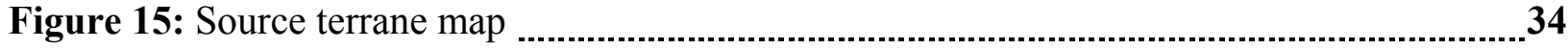

Figure 16: Sample location map _................................................................................. 36

Figure 17: Composite stratigraphic columns of the Tanqua, Laingsburg, and Ripon sub-basins

Figure 18: U-Pb Concordia plots for seven detrital zircon samples

Figure 19: U-Pb Concordia plots (Tera-Wasserberg plots) of all analyses for all seven detrital

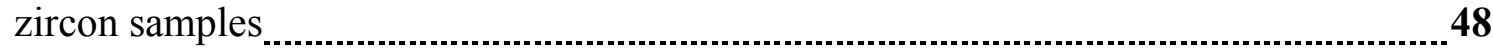

Figure 20: Thin-section image of sample 12ZA13 in plain and cross polarized light .................49

Figure 21: Sample 12ZA13 probability density plots ........................................................52

Figure 22: KDE plot and probability density plot comparison for sample 12ZA13 $\ldots \ldots \ldots \ldots \ldots \ldots . . . . .53$

Figure 23: Thin-section image of sample 12ZA26 in plain and cross polarized light ................54

Figure 24: Sample 12ZA26 probability density plots ......................................................57

Figure 25: KDE plot and probability density plot comparison for sample 12ZA26 ………..........58

Figure 26: Thin-section image of sample 09-BL-C1 in plain and cross polarized light...............59

Figure 27: Sample 09-BL-C1 probability density plots ......................................................62

Figure 28: KDE plot and probability density plot comparison for sample $09-\mathrm{BL}-\mathrm{C} 1 \ldots \ldots \ldots \ldots \ldots . . .63$

Figure 29: Thin-section image of sample 13ZA91 in plain and cross polarized light .................64

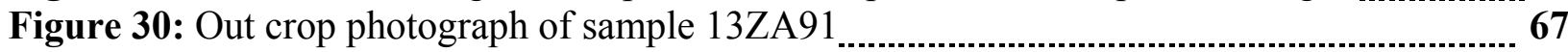

Figure 31: Sample 13ZA91 probability density plots .......................................................68

Figure 32: KDE plot and probability density plot comparison for sample 13ZA91 …...............69

Figure 33: Thin-section image of sample 13ZA93 in plain and cross polarized light ................ 70

Figure 34: Out crop photograph of sample 13ZA93

Figure 35: Sample 13ZA93 probability density plots .........................................................74

Figure 36: KDE plot and probability density plot comparison for sample 13ZA93 …..................75 
Figure 37: Thin-section image of sample 13ZA68 in plain and cross polarized light .................76

Figure 38: Out crop photograph of sample 13ZA68 .......................................................... 78

Figure 39: Sample 13ZA68 probability density plots ...................................................... 79

Figure 40: KDE plot and probability density plot comparison for sample 13ZA68 .....................80

Figure 41: Thin-section image of sample 13ZA74 in plain and cross polarized light ..................81

Figure 42: Sample 13ZA74 probability density plots ...................................................83

Figure 43: KDE plot and probability density plot comparison for sample 13ZA74 $\ldots \ldots \ldots \ldots \ldots \ldots . . . . . . . . . .44$

Figure 44: Normalized probability density plot of all seven U-Pb detrital zircon samples ........86

Figure 45: Geologic time period pie charts of each U-Pb detrital zircon sample ......................87

Figure 46: $\mathrm{U}-\mathrm{Pb}$ age $\mathrm{Vs}$. U/Th ratio plots for all seven $\mathrm{U}-\mathrm{Pb}$ detrital zircon samples ..................94

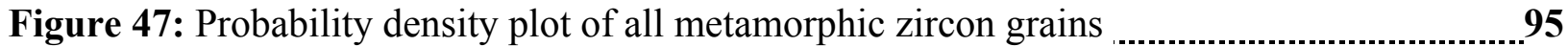

Figure 48: Composite stratigraphic columns of the Tanqua, Laingsburg, and Ripon sub-basin with U-Pb detrital zircon sample intervals labeled ............................................... 96

Figure 49: Framework grains in thin-section $\ldots$

Figure 50: Q-F-L diagram of Ripon sub-basin samples .......................................................

Figure 51: Q-F-L diagram of Laingsburg sub-basin samples ..........................................105

Figure 52: Q-F-L diagram of Laingsburg sub-basin samples ..........................................106

Figure 53: Q-F-L diagram of a Tanqua sub-basin sample .............................................109

Figure 54: Mineralogical abundances of all sandstone samples collected within the Karoo basin

Figure 55: Heavy mineral abundances 116

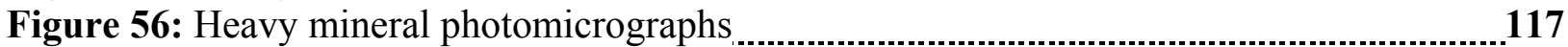

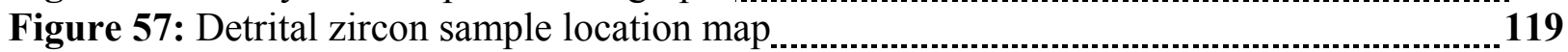

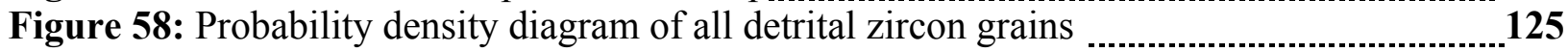

Figure 59: Normalized relative probability density diagram comparing detrital and source terrane zircons

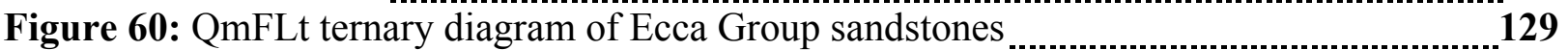

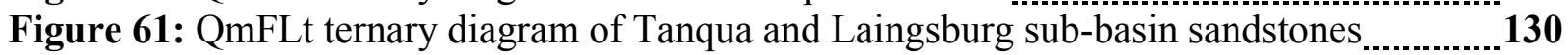

Figure 62: Qm FLt, QtFL, and LmLvLs diagrams for Ripon sub-basin samples ......................132

Figure 63: Qm FLt, QtFL, and LmLvLs diagrams for Laingsburg sub-basin samples ............134

Figure 64: Qm FLt, QtFL, and LmLvLs diagrams for Laingsburg sub-basin samples .............135

Figure 65: Qm FLt, QtFL, and LmLvLs diagrams for Tanqua sub-basin samples _.................137

Figure 66: Detrital Versus. Airfall ash composite stratigraphic column ..............................141

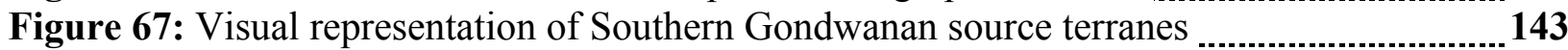

Figure 68: Schematic representation of the deposition of the Ecca Group during the Early to Late Permian

144

\section{List of Tables}

Table 1: Potential regional source material and their associated tectonic events _........................ 26

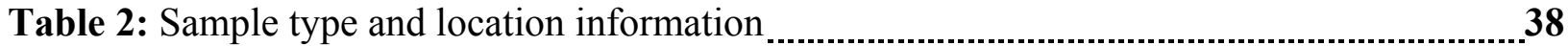

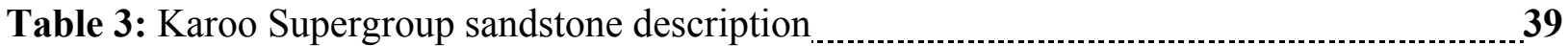

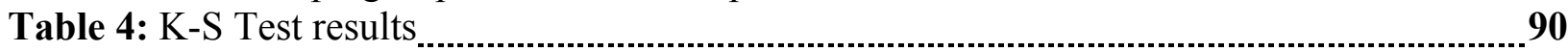

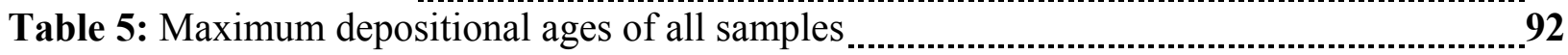

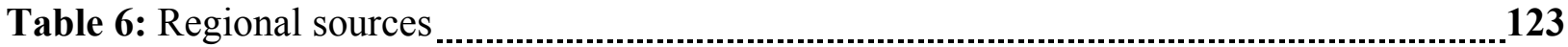




\section{Chapter I: Introduction}

\subsection{Sediment Origin}

Orogenic belts and sedimentary basins form in response to first-order tectonic events, thus, their physical development is highly dependent on the tectonic environment. Convergent tectonism is responsible for the formation of most orogenic belts and large basins generally develop adjacent to these orogenic belts as a result of flexural subsidence [Beaumont, 1981; McKay et al., 2013]. Flexural subsidence is driven by tectonic load causing elastic behavior of the rigid plate in which isostatic compensation results in the expression of flexure. [Busby and Ingersoll, 1995]. Topographically-high orogenic foldthrust belts generally serve as the tectonic load and the source for sediment that accumulates in topographic lows of "foreland basins" such as the South American Andes foreland basin [Busby and Ingersoll, 1995]. Sediment accumulation rates and distribution in a flexural foreland basin is therefore commonly dependent on the timing of deformation in the orogenic belt and magnitude of subsidence in the basin.

Orogenic uplift in convergent tectonic settings is one of the primary driving forces for basin formation and the provenance of sedimentary basin-fill [Dickinson, 1985]. Sedimentary provenance analysis is used to determine the origin of sediment derived from older parent rock assemblages [Weltje and Eynatten, 2004]. Different tectonic settings yield geologically and lithologically different source terranes; therefore, the composition of basinfill sediment may be predictable based on the tectonic setting responsible for creating both the basin and adjacent source rocks [Dickinson, 1985].

Sediment provenance can be determined using several different methods. Thinsection point-counting of sandstone samples to identify and quantify abundances of 
framework grain types can indicate provenance because source terranes typically yield clastic detritus of predictable composition [Dickinson, 1985]. Dense/heavy minerals can be used as a tracer to determine provenance as source rocks yield unique assemblages of dense accessory minerals. Detrital zircon geochronology is a common method used to determine provenance because zircon is a common accessory mineral in clastic sedimentary rock that can be dated using U-Pb geochronology to determine crystallization age. Zircons within clastic rocks generally represent a mixture of ages from an assemblage of rocks present within the drainage basin of the source area. The ages zircons within basin-fill can be compared to the zircon ages known in surrounding source terranes to determine sediment provenance. Provenance of the Karoo basin-fill is poorly constrained and understanding of the Cape Fold Belt/Karoo basin system evolution is incomplete. This research aims to determine provenance of Permian-Triassic Karoo Supergroup sandstones in order to identify source terranes which supplied sediment to the Karoo basin. Previous provenance studies have been inconclusive because specific source terranes could not be differentiated using conventional provenance methods [Fildani et al., 2007]. Source terranes supplying sediment to the Karoo basin could not be differentiated in previous studies in part because of limited age constraints on basin-fill strata [van Lente, 2004]. Additionally, the immature sediment composition of Karoo basin-fill is not consistent derivation from the quartzite units that form the adjacent fold-thrust belt (Cape Fold Belt) ; instead, the abundant feldspar and sedimentary lithic grains present within the Permian-Triassic Karoo basin-fill indicate a felsic igneous/continental terrane to the south of the Gondwanan margin as the sediment source, not the recycled orogenic source of quartzite and phyllite within the Cape Fold Belt [Veevers et al., 1994; van Lente, 2004]. The prime candidate for such a source would be either the Cape 
Granite Suite, the glaciogenic diamictite of the Dwyaka Formation or the Gondwanide southern magmatic arc.

This thesis presents new U-Pb detrital zircon ages, sandstone petrography data, and heavy mineral composition to better constrain provenance of Karoo basin-fill in order to determine the influence of the Cape Fold Belt on the formation of the Karoo basin. U-Pb detrital zircon data will be used to both constrain the maximum deposition ages of Karoo basin-fill and compare the age of Karoo zircons to the age of zircons of surrounding source terranes to constrain the provenance. Sandstone petrographic data will be used to determine the provenance of Karoo-basin fill based on the composition of regional source terranes. Dense/heavy minerals are used to determine provenance because source terranes resulting from different tectonic settings typically yield unique heavy mineral assemblages that can be differentiated in sedimentary basin-fill. Constraining provenance using these approaches will allow the timing of deposition, the location of sediment pathways, and approximate location of regional source terranes to be determined. This information will allow a better overall understanding of the evolution of the Cape fold belt/Karoo basin system.

\subsection{Geologic Background}

\subsubsection{Panthalassan Margin}

The Late Paleozoic Panthalassan Margin was an E-W trending active margin located along the southern limits of Gondwana. Tectonic activity along this margin can be characterized by north-vergent subduction of the Panthalassan plate beneath Gondwana, resulting in the formation of a magmatic arc, fold-thrust belt (Cape Fold Belt) and adjacent craton-ward sedimentary basins (Karoo basin of South Africa, Parana basin of South America, 
Bowen basin of Australia, and the Beacon basin of Antarctica; Fig. 1) [de Wit and Ransome 1992; Veevers et al. 1994; Johnson et al., 1997; Lopez-Gamund1 and Rossello 1998; Turner 1999; Faure and Cole 1999;Catuneanu et al., 2005; Lopez-Gamund1, 2006]. Remnants of these tectonographic provinces can be found on the continental fragments of Gondwana dissected during early Mesozoic South Atlantic rifting, and include South America, Africa, Falkland Islands, Antarctica, and Australia (Fig. 1) [Lopez-Gamundí, 2006]. The Gondwanide continental collision, as outlined by Pankhurst et al., (2006), can be characterized by the formation and north vergent movement of the North Patagonian Massif causing a collision with the southern margin of Gondwanna. This collision resulted in the formation of the Gondwanide fold-thrust belt and sedimentary basin also known as the Cape Fold Belt and Karoo basin. The Gondwanide fold-thrust belt and sedimentary basin of South Africa lie along strike with the Panthalassan margin in most paleogeographic reconstructions.

Although the magmatic arc is no longer preserved in the Karoo basin hinterland, its location may be inferred assuming the presence of remnant fold-thrust belts along the margins of continental fragments and craton-ward sedimentary basins are all associated with active tectonism along the margin [Lopez-Gamundí, 2006]. These fold-thrust belts and sedimentary basins appear to the east and west of South Africa and lie along strike with the Panthalassan margin in most paleogeographic reconstructions. Also, the Choiyoi magmatic province of South America is coeval with and geochemically similar to tuffaceous horizons present within Karoo basin-fill which strongly suggest a genetic linkage between arc magmatism, continental collision, and subduction along the Panthalassan margin. (Fig. 1) [van Lente, 2004; LopezGamundí, 2006; Vorster, 2013]. 


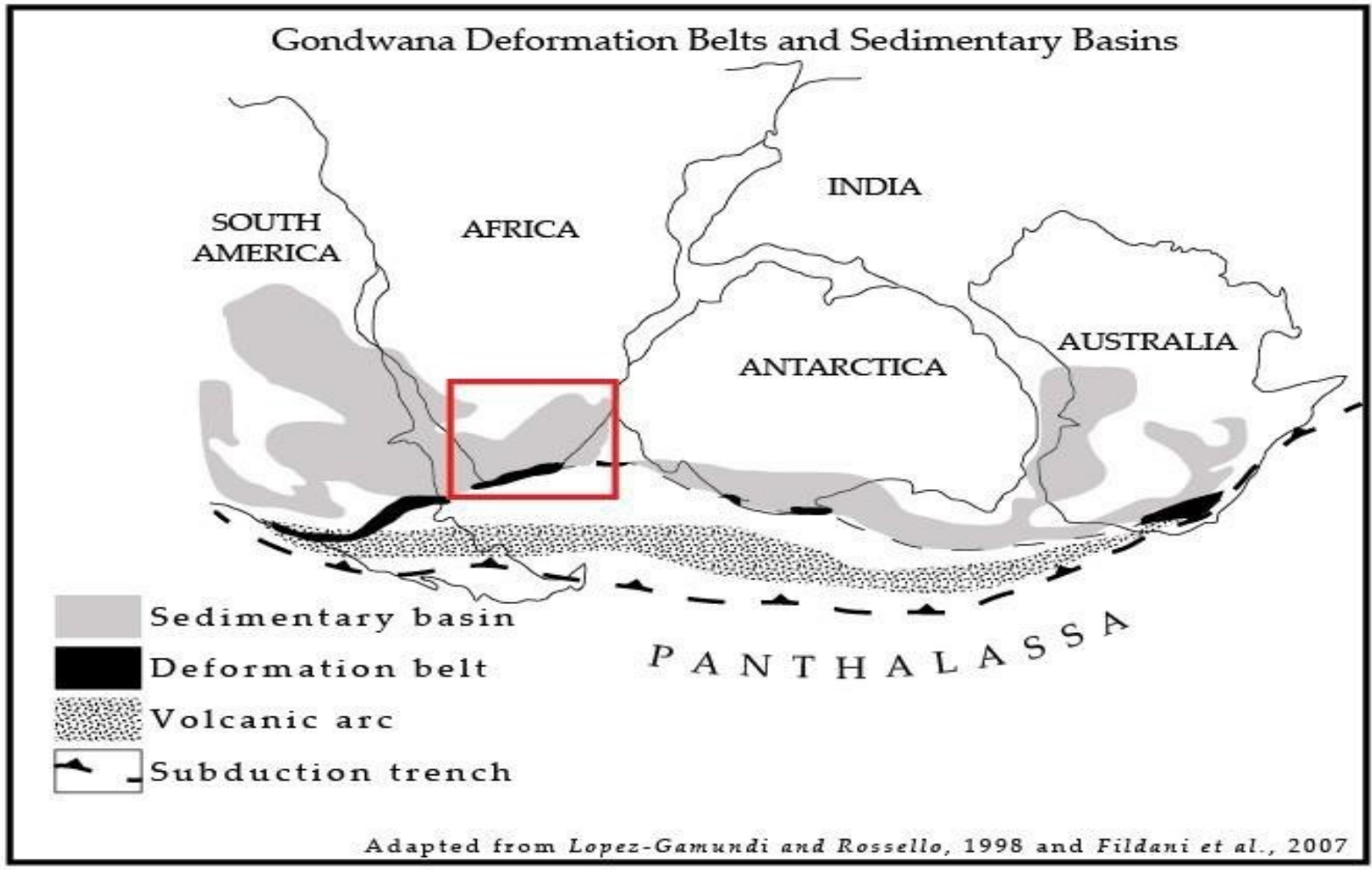

Figure 1: Paleogeographic reconstruction of Gondwana during the Permian and Triassic periods. The red box indicates the focus area of this study and includes the location of the Cape Fold Belt and adjacent Karoo Basin. Note that the extents of the magmatic arc and Panthalassan margin are inferred. The margin is thought to have existed along the southern Gondwanan margin due to the presence of remnant fold-thrust belts and craton-ward sedimentary basins [from McKay et al., 2012].

\subsubsection{Karoo Basin: Structure and Stratigraphy}

The Karoo basin of South Africa represents a major Late Paleozoic-Early Mesozoic Gondwanan depocenter produced by active convergent tectonism along the Panthalassan margin [Fildani et al., 2007]. The Karoo basin covers an area of $\sim 700,000 \mathrm{~km}^{2}$ and records tectonically-influenced late Carboniferous-Jurassic sedimentation (Fig. 2) [Johnson et al., 1997; Fildani et al., 2009; McKay et al., 2013]. The Karoo basin is partially filled by the Karoo Supergroup, a $\sim 10,000 \mathrm{~m}$ thick composite succession of clastic sediments [Johnson et al., 1996]. The Karoo Supergroup consists of three main stratigraphic groups: the Dwyka, 
Ecca, and Beaufort groups (Fig. 2 and Fig. 3) [Johnson et al., 1996; Fildani et al., 2009; Tankard et al., 2009]. The Dwyka Group was deposited in response to late Carboniferousearly Permian glaciation (Fig 3). The Dwyka Group reaches thicknesses of $\sim 800 \mathrm{~m}$ thick in the southern Karoo basin and is characterized by subaqueous, silt-dominated glacial diamictites with dropstones that were carried by floating ice rafts [Johnson et al., 1996; Catuneanu et al., 2005]. Correlation of the Dwyka Group with glacial deposits in South America, Africa, Antarctica, Australia, and India was used to develop the continental drift theory [Du Toit, 1937].

Deposition of the overlying Permian Ecca Group marked the end of glaciation and the beginning of marine deposition (Fig. 3) [Johnson et al., 1997]. The Ecca Group contains $\sim 3000 \mathrm{~m}$ of offshore mudstone that grade upward into fine-grained turbidites in the lower part, and shelf and deltaic deposits in the upper part, marking the transition from an underfilled to a nearly filled basin [Johnson et al., 1996; Tankard et al., 2009]. The Ecca Group is overlain gradationally by the upper Permian-lower Triassic Beaufort Group. The Ecca-Beaufort lithologic contact within the Karoo basin is associated with deltaic progradation within a highstand systems tract, causing diachronous deposition of deltaic deposits across a paleoshelf which youngs from south to north. [Rubidge et al., 1999; Rubidge et al., 2000].

The Beaufort Group marks the transition from deltaic deposition in the upper Ecca Group to fluvial deposition. The Beaufort Group reaches thickness of up to $7000 \mathrm{~m}$ in the southern portions of the Karoo basin and thins to 100-200 m toward the north [Johnson et al., 1996]. The Beaufort Group consists predominantly of mudstones and siltstones interbedded with lenticular and tabular sandstones deposited by a variety of fluvial systems [Catuneanu et al., 2005]. The focus of this study will be on the marine Ecca Group and lower Beaufort Group. 


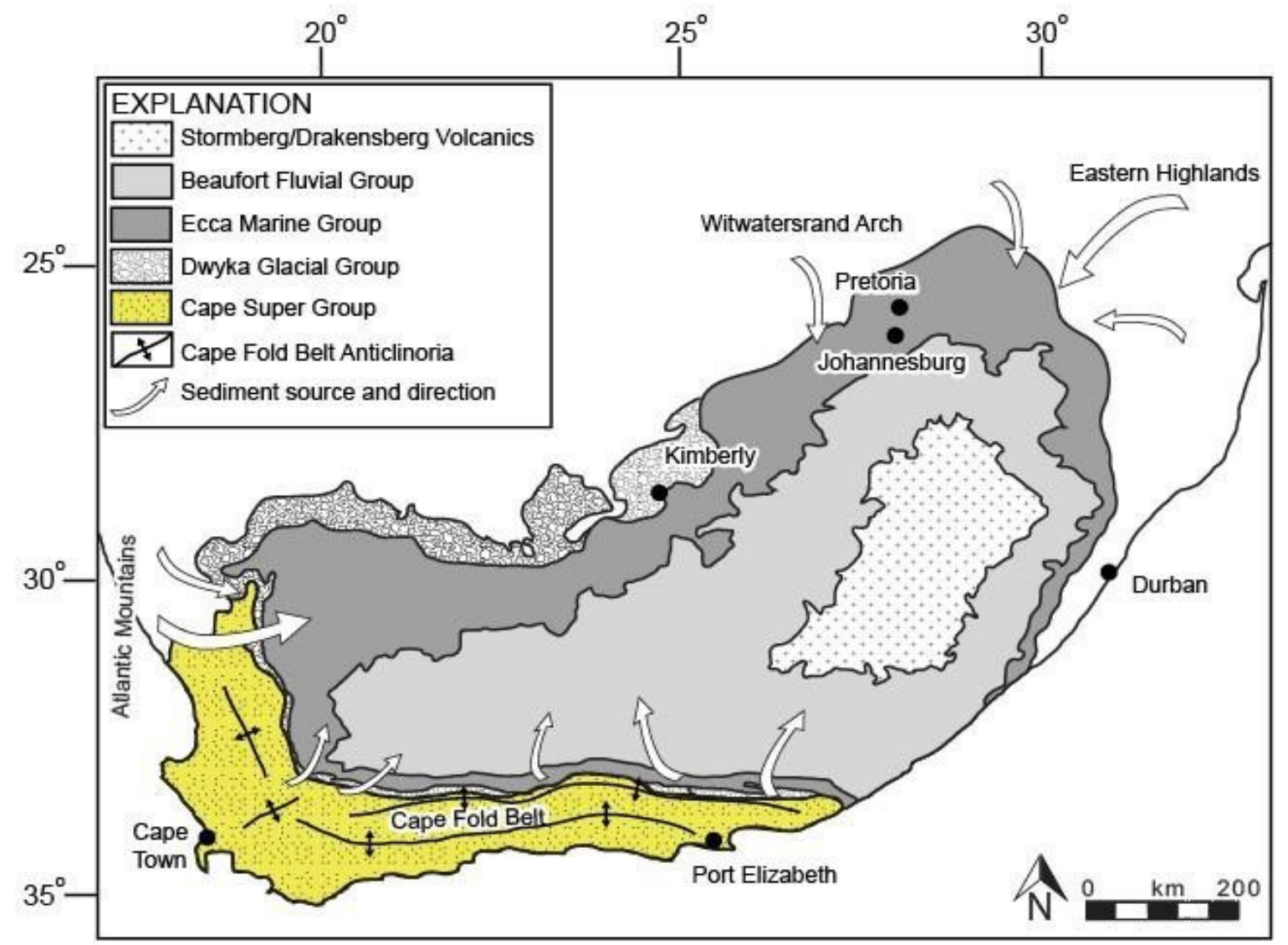

Figure 2: Simplified geologic map of the Cape Fold Belt and adjacent Karoo Basin with Cape Fold Belt structures, potential sediment sources, and paleoflow orientations displayed [After Veevers et al., 1994; McKay et al., 2013].

\subsubsection{Sub-basins}

The Karoo basins is subdivided into three sub-basins as a result of slightly different tectonic influences and varying water depths, grain sizes, subsidence rates, and fill patterns [Wickens, 1992; Wickens, 1994; Fildani et al., 2007]. From east to west adjacent to and along strike of Cape Fold Belt these sub-basins are the Tanqua, Laingsburg, and Ripon sub-basin. The Ecca and Beaufort groups are present in all three sub-basins but contain different formation names for some formations within each sub-basin (Fig. $7 \&$ 8) [Catuneanu et al., 2002]. The Tanqua and Laingsburg sub-basins occupy the western/southwestern portion of the Karoo basin and are separated by the Ceres syntaxis (Fig. $7 \& 8$ ). The Ripon sub-basin occupies the 
easternmost portion of the Karoo basin

(Fig. 7 \& 8). Subsidence magnitude was

likely greater in the Laingsburg sub-basin

which created more accommodation space

for a thicker Laingsburg Formation and

thinner Karoo Supergroup successions of

the Tanqua and Ripon sub-basins. In

addition to varying thickness within each

sub-basin, vertical facies variability also

exists. Grecula, (2000), Sixsmith, (2000),

Johnson et al., (2001), and Grecula et al.,

(2003) conducted studies which focused on

high resolution stratigraphy of the basin-

floor to slope turbidite fan complexes of

the Tanqua and Laingsburg sub-basins.

These studies emphasized that deposition

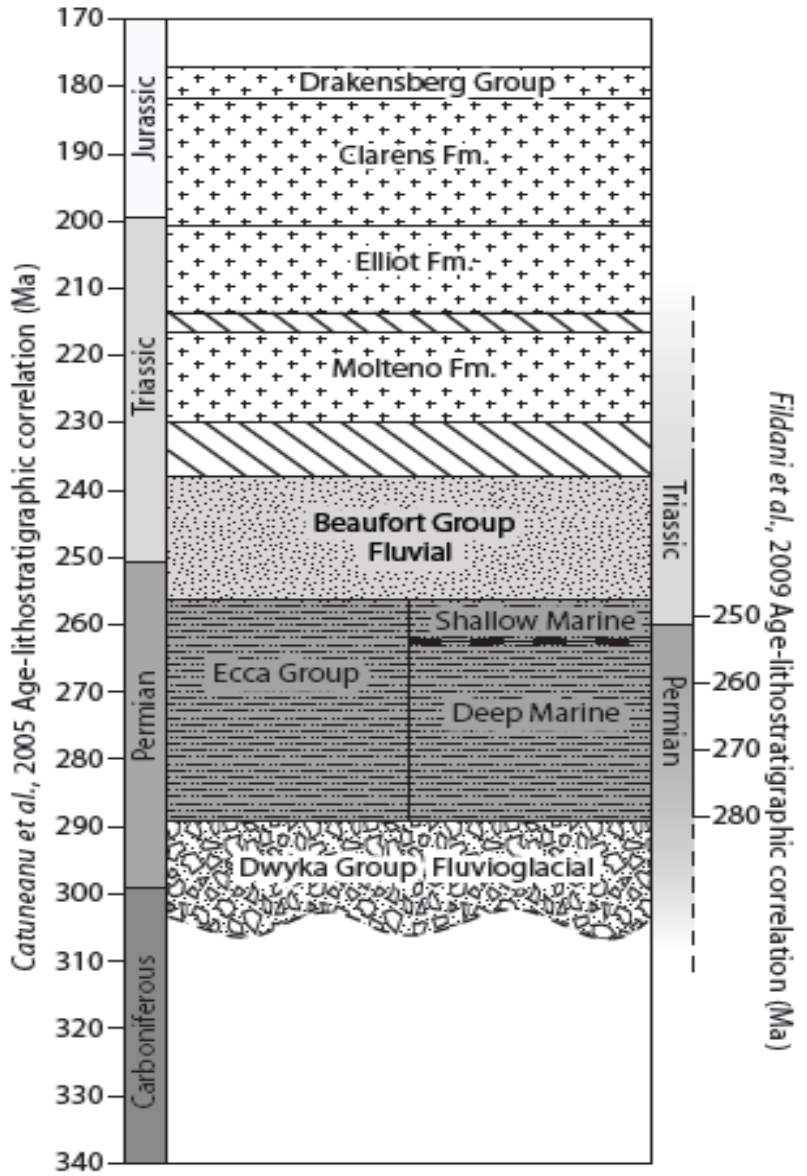

Figure 3: Generalized age-stratigraphic column of the Karoo Supergroup [Taken from McKay et al., 2012].

of the Ecca and lower Beaufort groups in

the Tanqua and Laingsburg sub-basins were coeval but vertical facies in the Laingsburg subbasin appear to be highly variable compared to the Tanqua sub-basin [Grecula, 2000]. This study will focus on the Permian/Triassic middle Ecca to lower Beaufort Group succession (Fig.

$3,4,5,6$ and 17).

\subsubsection{Tanqua sub-basin}

The Tanqua sub-basin, located approximately $300 \mathrm{~km}$ northeast of Cape Town, is 
separated to the southeast from the Laingsburg sub-basin by the Ceres syntaxis (Fig. 8). The interval of interest crops out over $650 \mathrm{~km}^{2}$ and thins out in a northerly and easterly direction [Johnson et al., 2001]. The lower and middle Ecca Group in the Tanqua sub-basin include the Prince Albert, White Hill, Collingham, Tierberg, and Skoorsteenberg Formations which are basinal muds that grade upward into fine-grained, arenaceous basin-floor turbidites interbedded with hemipelagic muds [Bouma \& Wickens, 1994; Flint et al., 2011]. Previous studies have indicated that up to five turbidite pulses have been preserved in the Skoorseenberg Formation of the Tanqua sub-basin [Bouma \& Wickens, 1994]. The overall thickness of the turbidite succession is greater than $450 \mathrm{~m}$ and ranges from distal basin floor through basin-floor subenvironments to a slope setting in the uppermost fan [Johnson et al.,

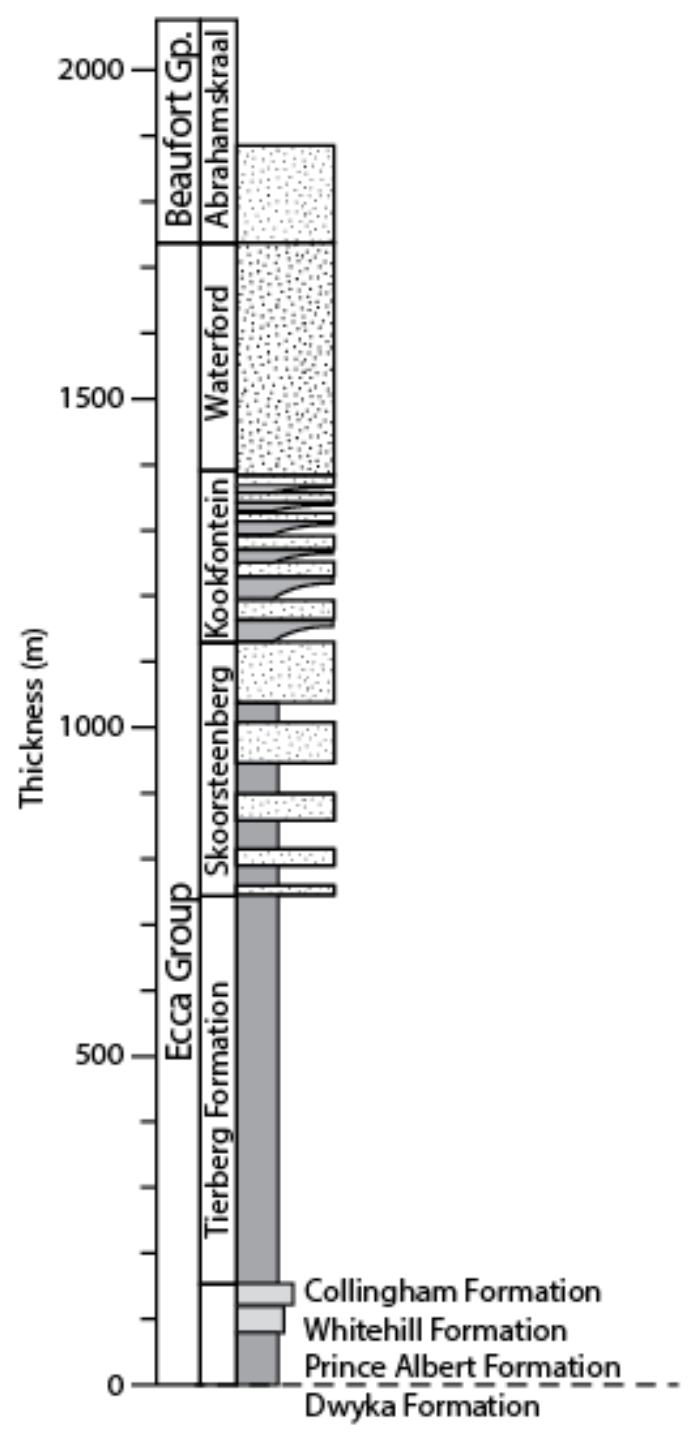

Figure 4: Generalized composite stratigraphic column of the Karoo Supergroup in the Tanqua sub-basin [Adapted from Fildani et al., 2007; McKay pers. comm.].

2001]. Fans in the Tanqua sub-basin are up to $65 \mathrm{~m}$ thick with sharp to gradational tops and bases and contain complex internal facies distributions [Johnson et al., 2001]. In the Tanqua sub-basin, interbedded prodelta sandstone and mudstone deposits of the lower Ecca Group represent the underfilled basin that grade upward into the deltaic Waterford Formation of the 
Upper Ecca Group (Fig. 4). The Waterford Formation grades into the fluvial deposits of the Abrahanmskraal Formation in the lower Beaufort Group which represents a filled basin stage. Thus the Ecca-Beaufort Group contact mark the transition from an underfilled to nearly filled basin [Bouma \& Wickens, 1994; Johnson et al 1996]. A study conducted by Rubidge et al. (2000) used marine biostratigraphy and plant fragments to define the Ecca/Beaufort contact in the southern Karoo basin.

\subsubsection{Laingsburg sub-basin}

The Laingsburg sub-basin is located approximately $300 \mathrm{~km}$ northeast of Cape Town (Fig. 8). The Laingsburg sub-basin is separated from the Tanqua sub-basin by the Ceres syntaxis to the northwest and from the Ripon sub-basin to the east by approximately $500 \mathrm{~km}$ and slight bends in the Swartburg Range of the Cape Fold Belt. Formations of the lower and middle Ecca Group (Prince Albert, White Hill, Collingham, Vischkuil, and Laingsburg Formations) in the Laingsburg sub-basin are similar in composition, architecture, and age to the correlative units in the Tanqua and Ripon sub-basin due to similar depositional conditions [Bouma \& Wickens, 1994; Flint et al., 2011]. These formations can be differentiated from sub-basin to sub-basin by varying grain size, spatial extent, and thickness.Laingsburg subbasin strata contain an overall coarser grain size and thicker turbiditic succession compared to the Tanqua sub-basin. The Laingsburg Formation of the Laingsburg sub-basin contains a series of six sandstone successions interpreted as basin-floor, toe-of-slope, and slope turbidite complexes that are separated by hemipelagic mudstone [Wickens, 1992; Wickens, 1994, Grecula et al., 2003a; Grecula et. al 2003b; Sixsmith et al., 2004]. The turbidite fans contain gradational to sharp upper and basal bed contacts and truncating feeder channels in most fan successions [Sixsmith et al., 2004]. Overall, sand units in the turbidite fans of the Laingsburg 
sub-basin are structureless with occasion graded bedding and ripple laminations and appear to be much sandier than the shaley, mud-rich fans of the Tanqua sub-basin [Bouma and Wickens, 1994; Wickens and Bouma, 2000; Vorster, 2013.]. The Laingsburg Formation (750 m) is thicker than the correlative Skoorsteenberg Formation $(450 \mathrm{~m})$ in the Tanqua sub-basin (Fig. 17) [Sixsmith et al., 2004]. The upper Ecca (Waterford Formation) and lower Beaufort Groups (Abrahanmskraal Formation) of the Laingsburg sub-basin contains a similar transition as the Tanqua sub-basin in which the basin transitions from underfilled to nearly filled basin within the gradational Ecca-Beaufort contact [Bouma \& Wickens, 1994; Johnson et al 1996]. A variety of trace and invertebrate fossils are present in the Laingsburg formation and can be used as a good indicator for the Ecca/Beaufort Group contact [Rubidge et al., 2000; Johnson, 2006].

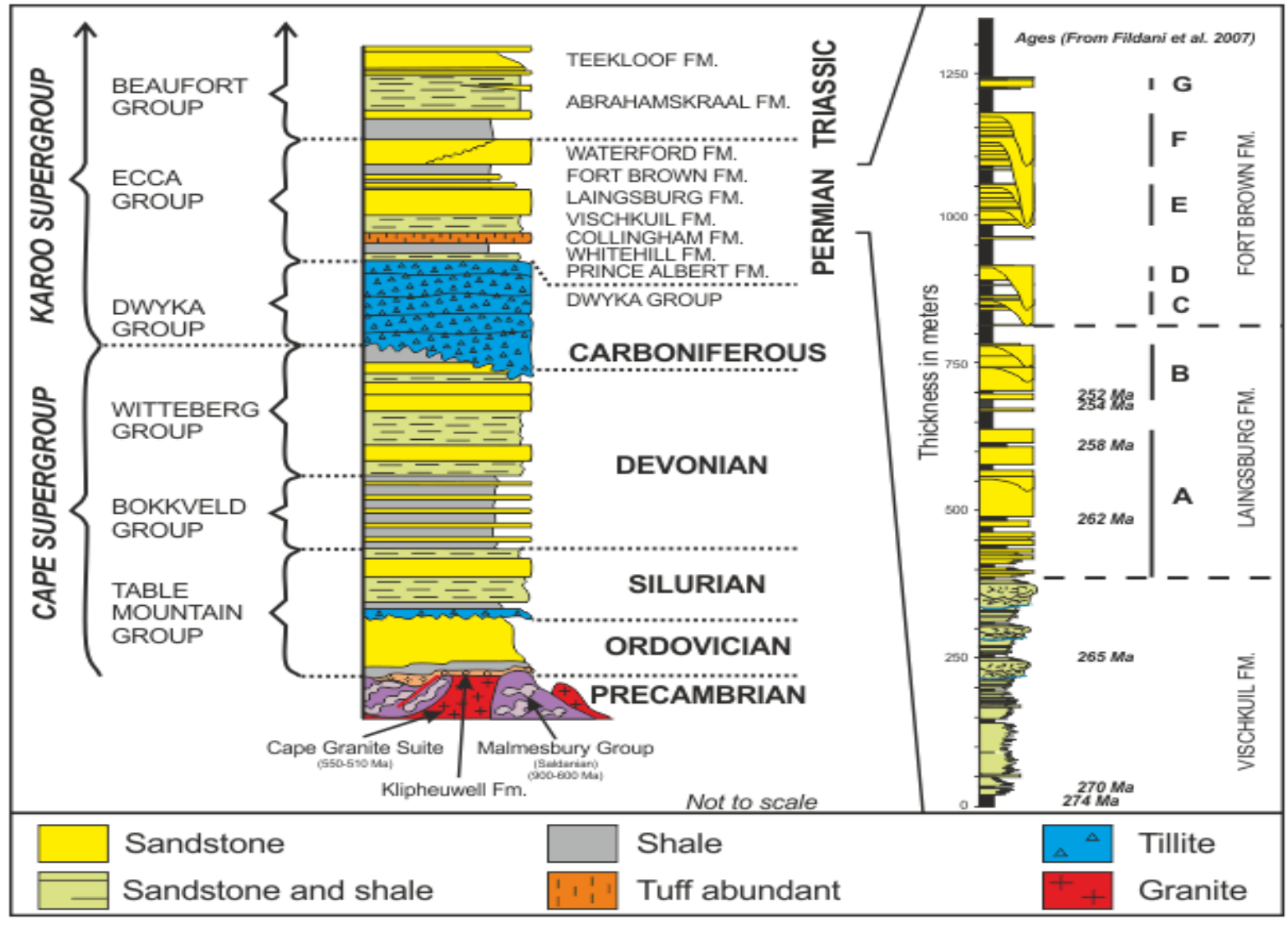

Figure 5: Generalized stratigraphic column of the Cape and Karoo Supergroups and the underlying Pre-Cambrian basement [After Wickens, 1994; Taken from Flint et al., 2011]. 


\subsubsection{Ripon sub-basin}

The Ripon sub-basin occupies the easternmost Karoo basin in the area approximately $100 \mathrm{~km}$ northeast of Port Elizabeth (Fig. 8). The Ripon sub-basin displays similar stratigraphic trends as the Tanqua and Laingsburg sub-basins in that the formations of the lower and middle Ecca Group (Prince Albert, White Hill, Collingham, and Ripon Formations) is characterized basinal muds followed by sand rich, submarine turbidite deposition [McKay, pers. comm.]. Up to four turbidite fan systems may exist within the Ripon Formation. Turbidite fans within the Ripon sub-basin contain slightly coarser sediments and are separated by greater thicknesses of hemipelagic muds than the fans within the Tanqua and Laingsburg

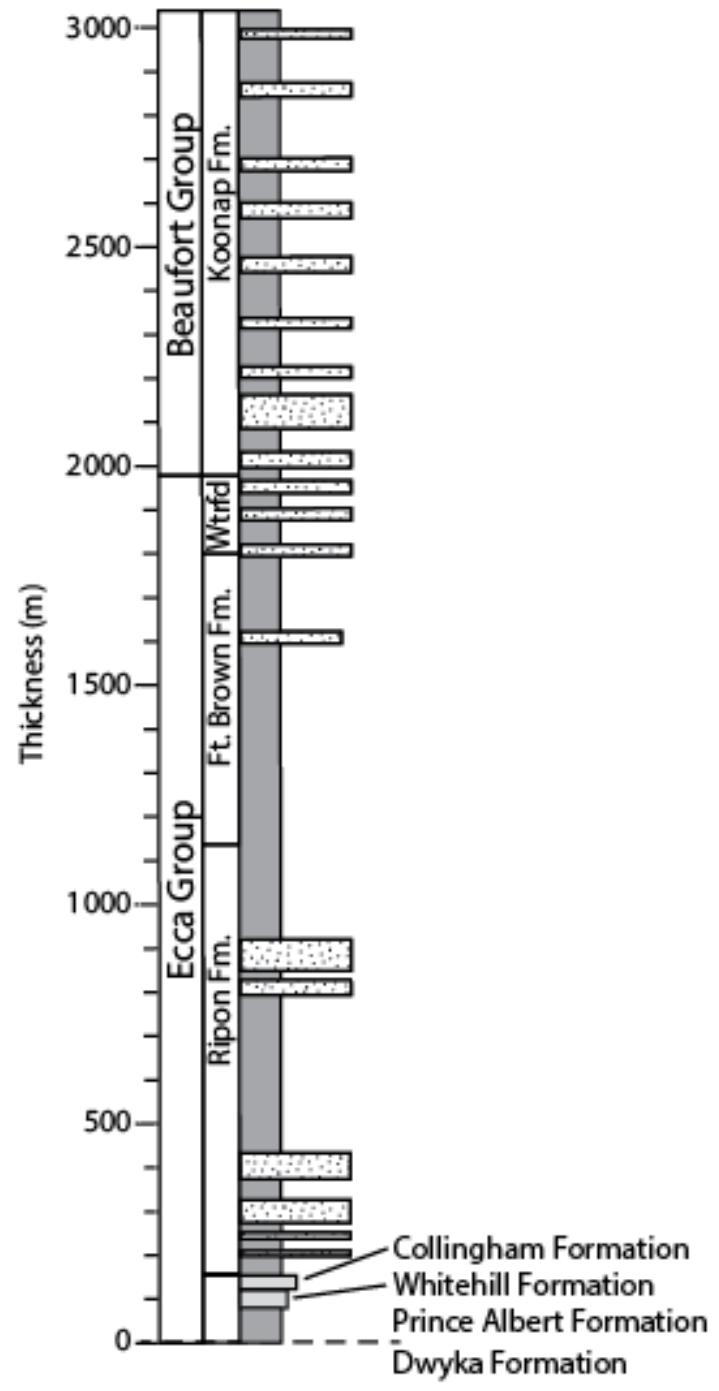

Figure 6: Generalized composite stratigraphic column of the Karoo Supergroup in the Ripon sub-basin [McKay, pers. comm.].

sub-basin (Fig. 17). The Waterford

Formation of the upper Ecca Group and the Koonap Formation of the lower Beaufort Group contain prodelta and delta deposits which are overlain by fluvial deposits in the Koonap Formation of the lower Beaufort Group. Various trace fossils are found throughout the middle 
Ecca through lower Beaufort Groups which are indicative of deep water conditions and silicified logs with annual rings are common in the lower Ripon Formation [Johnson, 2006; Johnson and Kingsly, 1993].

\subsubsection{Cape Fold Belt}

The Cape Fold Belt (CFB) of South Africa is a major remaining structural remnant of the Cape Orogeny preserved on the African continent and is hypothesized to have been the topographic load causing subsidence of the Karoo basin [Catuneanu et al., 2008]. The CFB was uplifted during the Gondwanide Orogeny as a result of compression due to subduction of the paleo-Pacific plate beneath the Gondwanan supercontinent along the Panthalassan margin (Fig. 10). The CFB is thought to have formed as a result of multiple compressional events during the Permian and Triassic periods, as indicated by ${ }^{40} \mathrm{Ar} /{ }^{39} \mathrm{Ar}$ ages of syndeformational micas collected from the southern CFB that reflect major tectonic cooling events at 278, 258, 247, 230 Ma [Hälbich et al., 1983]. Basin models produced using airfall ash geochronology to constrain sediment accumulation rates reveal subsidence phases at 280-276 Ma, 270-258 Ma, and 246 Ma (McKay et al., 2012) which coincide with the cooling events in the CFB documented by Hälbich et al. (1983).

The CFB consists of two main segments that are separated by the Ceres syntaxis [Booth, 2011] (Fig. 8). The eastern segment of the CFB trends east-west and is positioned along the modern southern South African coast, forming the modern highlands of the Oteniqua and Swartburg Ranges. The western segment of the CFB is north-northwesterly trending, forming the modern highlands of the Cedarburg Range. The Ceres syntaxis is a northeastsouthwest oriented structural high that separates the two main segments of the CFB. The axial 
trace of the syntaxis trends into the Karoo basin as the Hex River anticlinorium and separates the Tanqua sub-basin to the northwest from the Laingsburg sub-basin to the southeast. Development of this syntaxis was probably the result of right-lateral transpression and northvergent compression along the southern Gondwanan margin during the mid-late Permian and may have served as a sediment pathway for Karoo strata [Tankard et al., 2009; Booth, 2011]. The Ceres syntaxis is also the result of topographic inversion in which the structural high was incised to create pathway through the Cape Fold Belt [Brezinski, 1989]. Topographic inversion is a process that occurs in which structural high become topographic low by fractures forming at the top of an anticlinal fold allowing increased water penetration and erosion [Brezinski, 1989].

The Port Elizabeth antitaxis lies to the north of Port Elizabeth on the modern South African coast and formed in response to right-lateral transpression produced by the Gondwanide Orogeny during the mid-late Permian [Johnston, 2000]. The Ripon sub-basin lies to the north of the Port Elizabeth antitaxis. It is possible that Port Elizabeth antitaxis contained sediment pathways around its flanks allowing sediment to be transported from the active volcanic arc to the Karoo basin based on the north to northwest paleocurrent direction outline by Veevers et al., (1994). It is also possible that Port Elizabeth antitaxis was the result of present day tectonic processes associated with the Agulhas Falklands Fracture Zone as mapped by Johnston, (2000) and had no impact on sediment delivery into the Karoo basin during the Permian [Booth, 2011]. However, paleomagnetic constraints reveal that until at least Early Jurassic times the Falkland Islands were still located off the southeastern coast of Africa suggesting that the fracture zone likely didn't form until the Late Jurassic to Early Cretaceous periods [Thomson, 1998] 
The CFB consists of deformed Cape Supergroup strata that were deposited as passive margin sediments in the early Paleozoic Cape Basin which filled from the north based on southward-oriented paleocurrent indicators [Veevers et al., 1994; Vorster, 2013]. The Cape Supergroup consists of three groups, listed in stratigraphic order: the Ordovician-Silurian Table Mountain Group (480 Ma), Early Devonian Bokkeveld Group (400 Ma), and Late Devonian Witteberg Group (350 Ma) [Broquet, 1992; Veevers et al., 1994; Shone and Booth, 2005; Thamm \& Johnson, 2006; Fourie et al., 2010] (Fig. 7 \& 8). The Cape Supergroup is composed of quartzites interbedded with phyllites that are to $8 \mathrm{~km}$ thick to the south in the Western Cape region and drastically reduced thickness and eventually pinches out on to crystalline basement to the northeast just south of Lesotho [Cole, 1992; Veevers et al., 1994; Thamm \& Johnson, 2006]. Sediments within Cape Supergroup strata are thought to have been derived from a northern cratonic source as well as from mobile belts and intrusive igneous provinces associated with the Neoproterozoic Pan African Orogeny including the Kaapvaal Craton, Namaqua-Natal Province, and Cape Granite Suite [Johnson, 1991; Vorster, 2013]. 


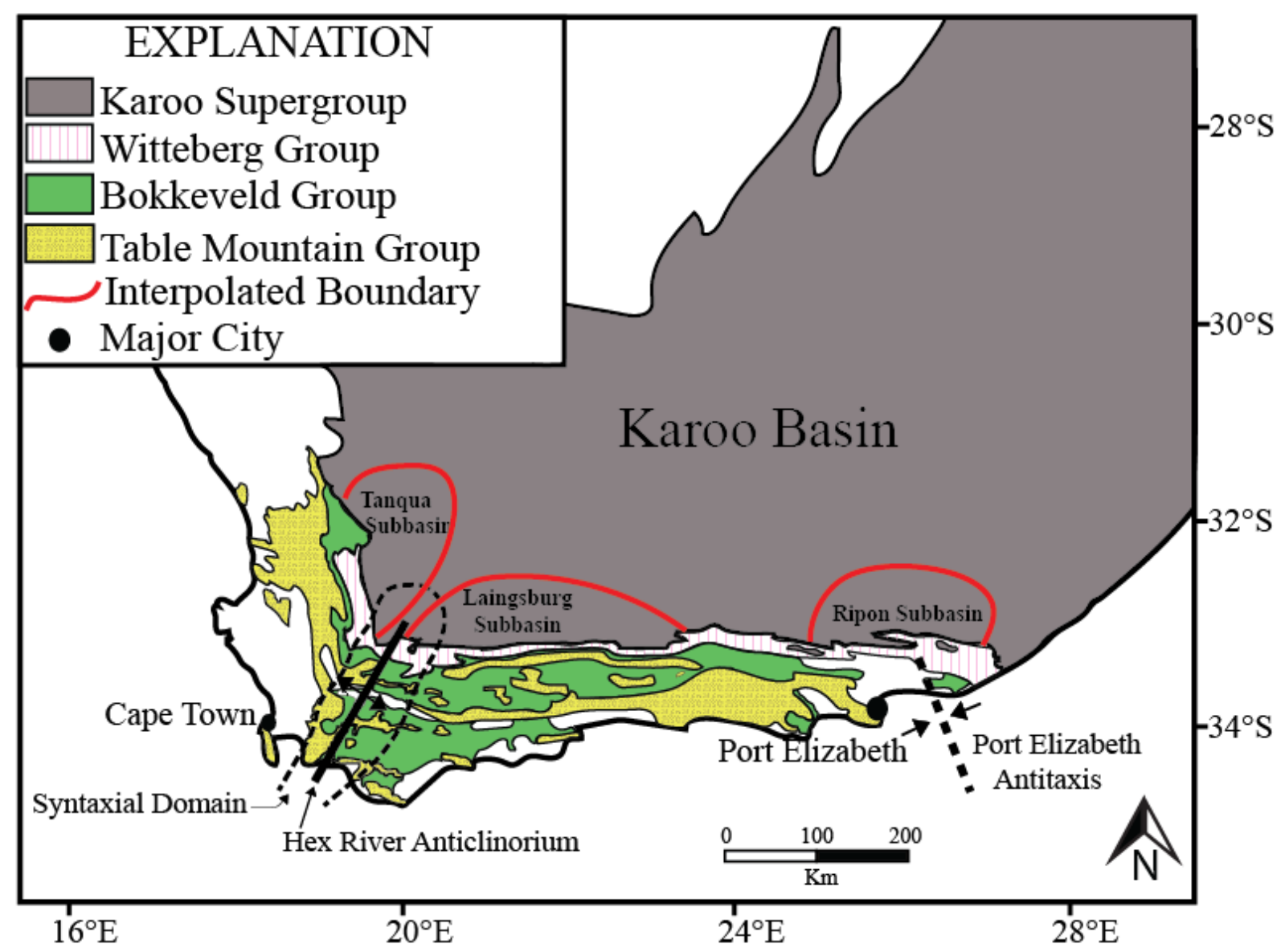

Figure 7: Geologic map displaying the regional distribution of the three major groups of the Cape Supergroup. The syntaxial domain represents the Ceres syntaxis. Note the relationship between the Ceres syntaxis and the E-W \&N-S trending limbs of the Cape Fold Belt. Also note the positions of the Port Elizabeth (interpolated) antitaxis and Ripon sub-basin [modified after Cloetingh et al., 1992]. 


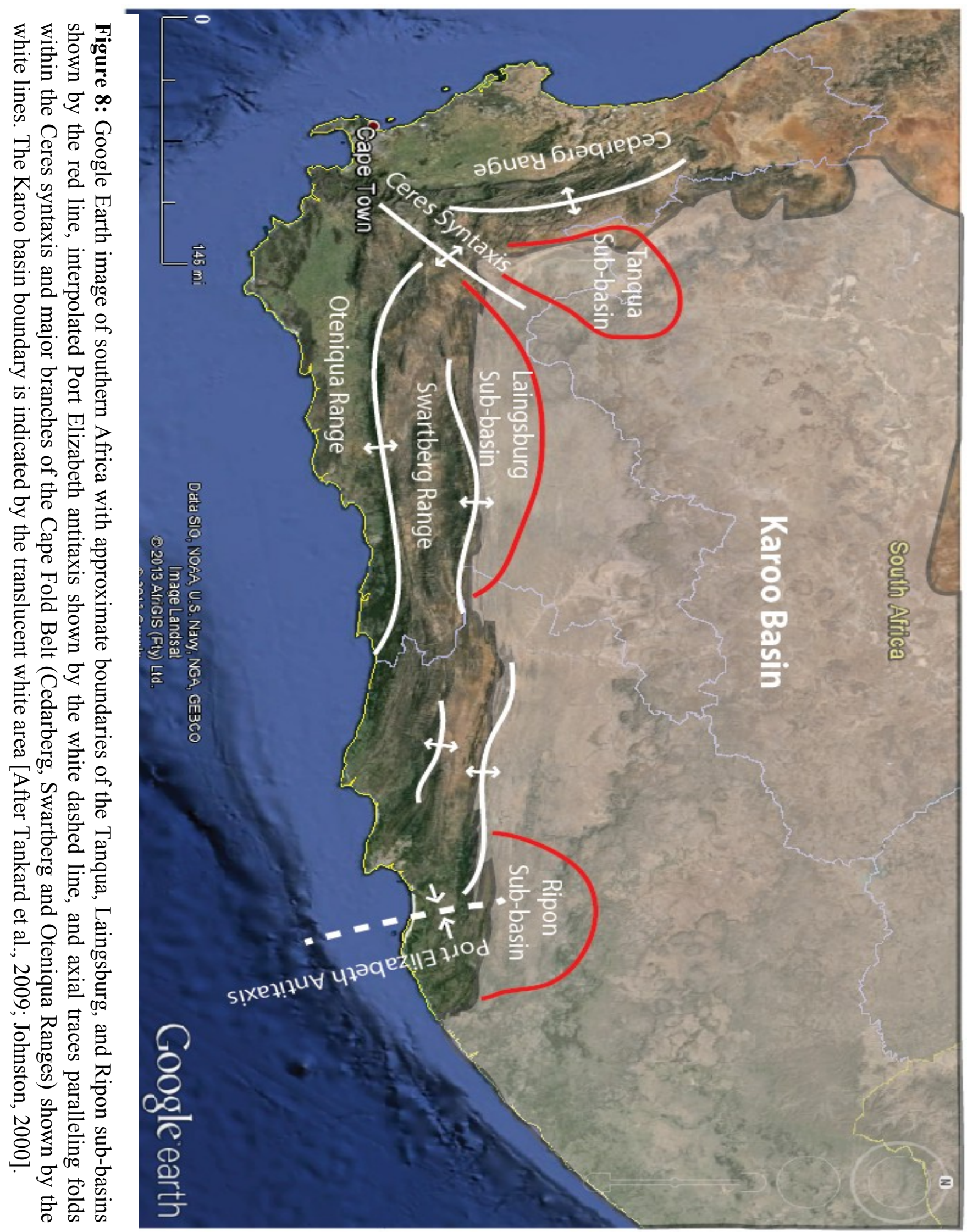




\subsection{Subsidence Mechanism}

Two competing models exist to explain subsidence of the Karoo basin. The flexural subsidence model suggests that the Karoo basin subsided due to the load created by the growth of the CFB. The mantle driven dynamic subsidence model suggests that the Karoo basin was pulled down via convection cells in the mantle with the absence of the CFB.

\subsubsection{Flexural Subsidence}

The Karoo basin has been traditionally classified as a retroarc foreland basin which formed due to lithospheric flexure in response to crustal loading induced by growth of the CFB (Fig. 10). This model is supported by the syndeformational deposition of Karoo basin strata adjacent to the Ceres syntaxis. In the area of the Hex River anticlinorium, lower Ecca Group strata thin over the syntaxis providing evidence of simultaneous folding and syntectonic sedimentation [de Beer, 1990]. Additionally, Karoo strata thin to the north, away from the Cape Fold Belt, which is consistent with deposition into a foreland basin setting. However, the accuracy of a retroarc foreland basin model is suspect because: 1) the Karoo basin is thought to have developed $>1000 \mathrm{~km}$ from the Panthalassan margin (Tankard et al., 2009) and 2) sedimentation into the Karoo basin is thought to predate initial CFB deformation (Fig. 9)[Tankard et al., 2009]. If these statements are true, it is unlikely the Karoo basin is a retroarc foreland basin because 1) foreland basins typically do not form great distances (greater than $1000 \mathrm{~km}$ ) from the active margin and 2) foreland basins generally form in response to crustal loading, so if deposition in to the Karoo preceded deformation of the CFB, then Karoo basin subsidence was not driven by crustal flexure in response to topographic loading, but via some other mechanism, such as mantle flow driven dynamic subsidence as has been suggested by Tankard et al., (2009). 


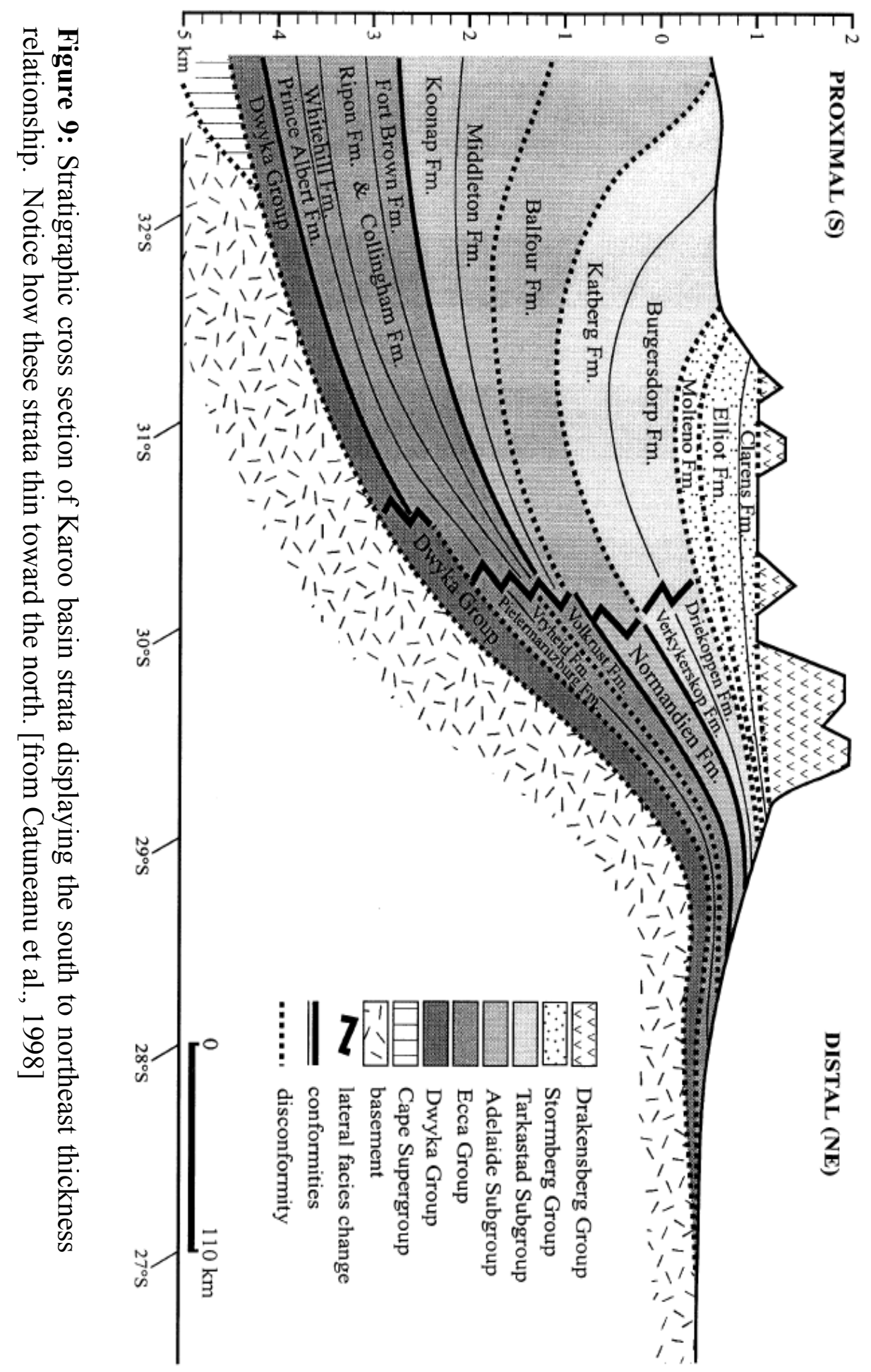




\section{a. Early Carboniferous}

\section{Passive Margin}

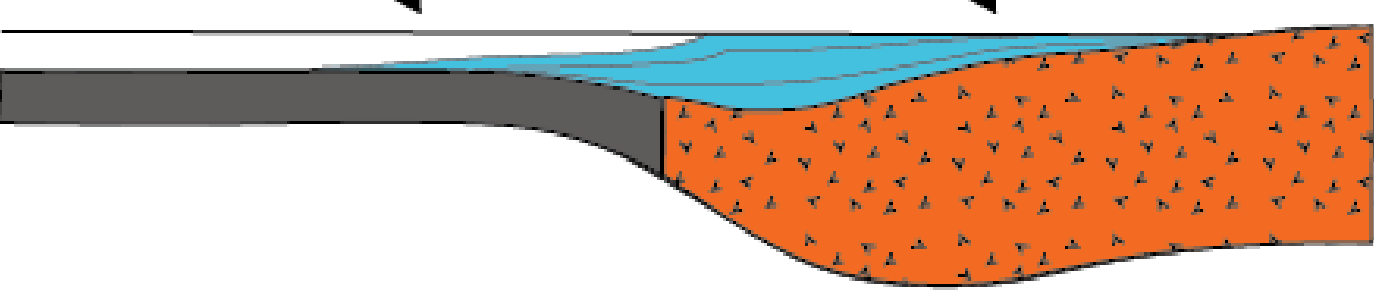

b. Late Permian

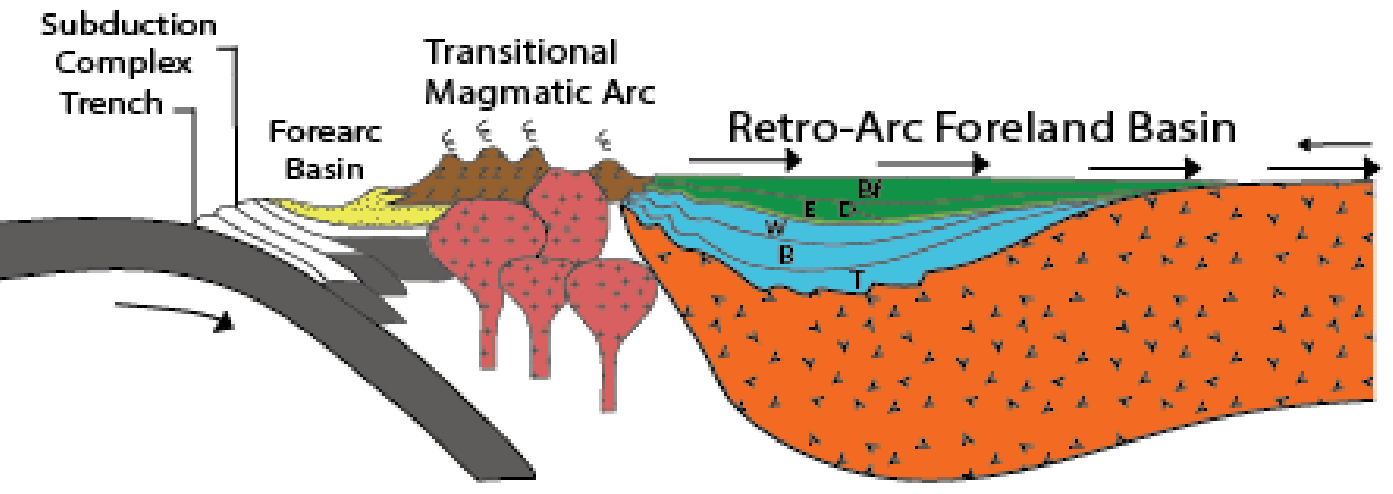

\section{c. Late Triassic}

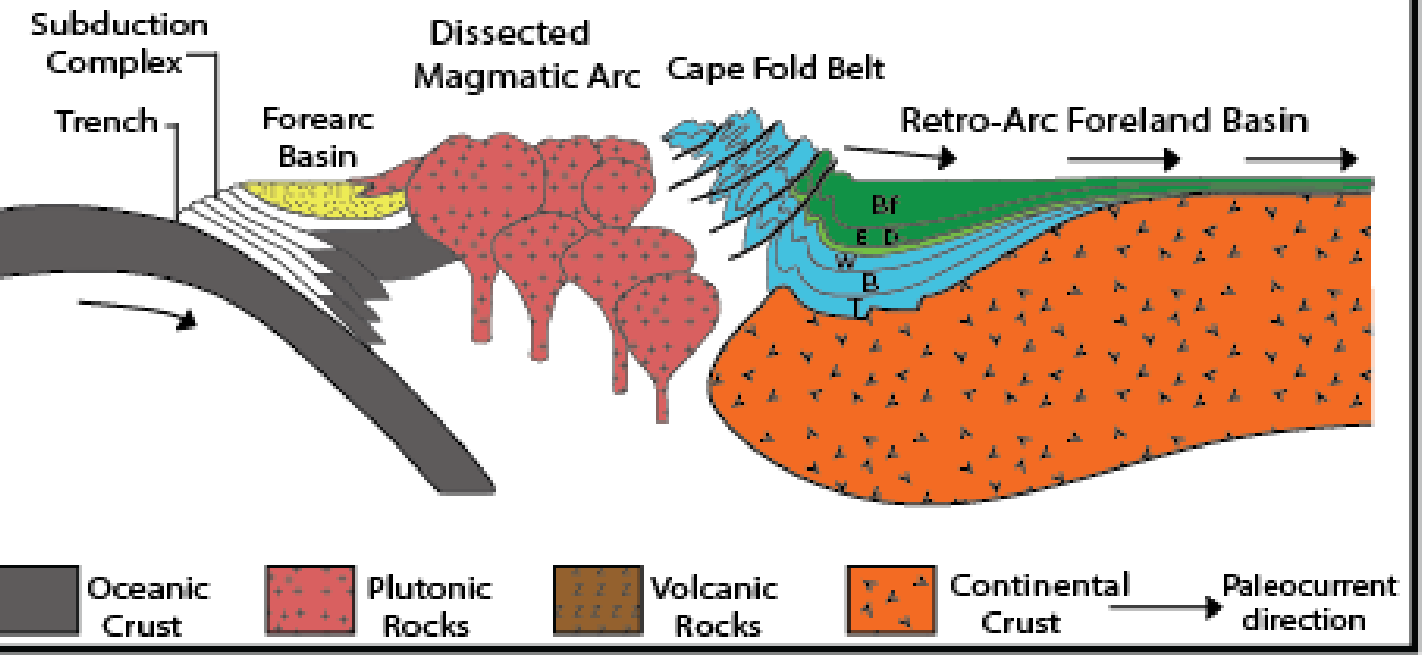

Figure 10: Schematic representation of Karoo basin evolution from the Early Carboniferous to Late Triassic displaying the relationship between subduction, magmatism, orogenesis and Karoo basin formation [redrawn and modified from Johnson et al., 1996; and Vorster, 2013]. B = Bokkeveld Group, Bf= Beaufort Group, D = Dwyka Group, E = Ecca Group, T = Table Mountain Group, and W = Witteberg Group. 


\subsubsection{Mantle Driven Dynamic Subsidence}

An alternative model has been proposed that suggests mantle-flow driven dynamic subsidence may have resulted in the development of the early Permian Karoo basin. Mantleflow driven dynamic subsidence is a process by which convection cells within the asthenospheric mantle develop in response to subduction causing downward deflection of the lithosphere and producing widespread low-amplitude subsidence compared to higher amplitude flexural subsidence (Fig. 11). It is proposed that brittle lithospheric blocks separated by crustal-scale faults are displaced downward, creating widespread subsidence and accommodation space for Karoo Supergroup strata [Tankard et al., 2009]. This model is highly contentious due to the lack of laterally continuous crustal scale faults with documented high magnitude displacement to accommodate subsidence and the absence of a modern analogue.

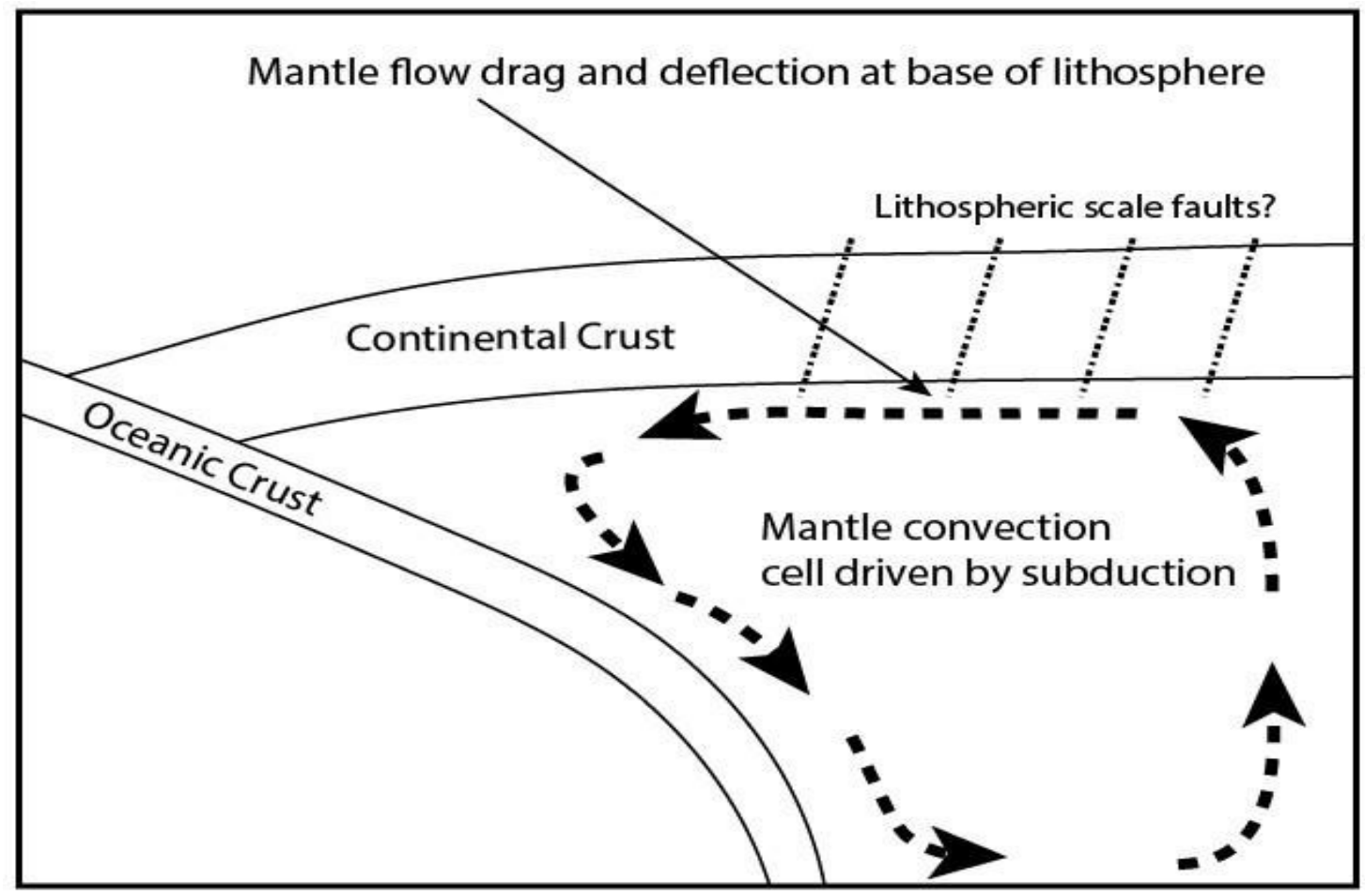

Figure 11: Schematic representation of mantle driven dynamic subsidence in which convection cells in the mantle induced by drag from the subducting plate causes basin subsidence by displacing crustal blocks along lithospheric scale faults. 


\subsection{Research Problem}

Previous studies conducted within the Karoo basin have successfully characterized Karoo sediments and basin-fill patterns but have been unsuccessful at constraining the provenance of Karoo basin-fill using conventional methods [Fildani et al., 2007]. Previous work conducted by Elliot and Watts (1974), Lock (1980), Kingsley (1981), Hälbich (1983), Cole (1992), Veevers et al. (1994), Adelmann and Fiedler (1998) suggest that the main source area for the Ecca and Beaufort Groups of the Karoo basin was the CFB. This interpretation was based the proximity of the CFB to the Karoo basin and on sandstone framework grain composition which plotted within the recycled orogen provenance field of Dickinson (1979) combined with paleocurrent indicators oriented toward the north/northeast or away from the CFB and toward the Karoo basin depocenter. However, these studies were challenged by Johnson (1991), who used sandstone petrography on the Ecca and lower Beaufort Groups in the southwestern Karoo to show that framework grain composition of the Karoo sandstone from the southwestern Karoo basin plotted in the transitional arc provenance field of Dickinson (1979). The results of Johnson (1991) agreed with earlier studies by Elliot and Johnson (1972), Martini (1974) and Visser (1979), who suggested a southern magmatic arc south of the CFB may have sourced Karoo Supergroup strata due to the abundance volcanic clasts present within the sandstone. Mineral chemistry of detrital heavy minerals such as garnet, tourmaline, and biotite analyzed by electron microprobe were taken from sandstones within the Skoorsteenberg Formation, Vischkuil Formation and Laingsburg Formation of the Laingsburg sub-basin and results indicate two source assemblages of high-grade metamorphic and granitic rocks south of the Cape Fold Belt in the Gondwannan plate overlying the subduction zone [Scott, 1997]. Since the Cape Fold Belt was not found to be a major a source for Karoo Supergroup sandstones, this lead Scott (1997) to suggest that the 
Cape Fold Belt may have still been submerged during deposition of the Karoo Supergroup strata and that therefore, the CFB was not yet uplifted and subaerially exposed during Permian time, which would indicate little if any compressional deformation of the CFB had occurred in the CFB during the Permian. Mineralogical and geochemical studies conducted by Andersson et al., (2003) and Andersson et al., (2004) using $\mathrm{Sm} / \mathrm{Nd}$ isotopes and rare-earth elements on mudstones from turbidites in the Tanqua sub-basin reveal uniform composition that is consistent with derivation from the Cape Fold Belt and a contemporaneous southern magmatic arc.

A provenance study conducted by Faure et al., (1996) using $\mathrm{Sm} / \mathrm{Nd}$ isotopic composition of mudstones from the Swartrant (lower Ecca Group equivalent) and Grootegeluk (middle Ecca Group equivalents) Formations of the Permian Karoo Supergroup in the northeaster Karoo basin suggests that mudstones from the northern Karoo basin were sourced by erosion of older $(>500$ Ma) rocks such as the Namaqua-Natal metamorphic provenance and Kaapvaal craton found in terranes to the north of the Karoo basin whereas Karoo Supergroup sandstones contains sediments sourced from younger rocks $(<500 \mathrm{Ma})$ to the south such as the southern magmatic arc. Northern source areas are inferred due to the proximity of surrounding ancient cratons and the southwestern paleocurrent direction present within the northeastern Karoo basin.

Studies conducted by Veevers and Saeed (2007), and Veevers and Saeed (2013) used U$\mathrm{Pb}$ zircon dating, $\mathrm{Hf}$ isotopes on detrital zircons, and $\mathrm{Sm} / \mathrm{Nd}$ isotopes for Karoo Supergroup sandstone samples of the lower and middle Ecca Group from the northern Karoo basin. Their results reveal dominant age populations at $500 \mathrm{Ma} 624 \mathrm{Ma}$, and $1060 \mathrm{Ma}$ which likely are sourced by rocks of the Kaapvaal craton, Namaqua-Natal metamorphic provence, CFB and the Eastern Highlands which are outlined by Van Vuren and Cole (1979) and Vorster (2013). These provenance signatures suggest that the Karoo Supergroup in the northeastern Karoo basin may 
have a slightly different provenance signature than Karoo Supergroup sandstones within the south eastern and southwestern Karoo basin. Katemaunzanga et al., (2009) conducted a study using rare-earth elements on mudstones and sandstone petrography coupled with paleocurrent data on sediments from the Balfour Formation in the Beaufort Group. Sandstone petrography data from Katemaunzanga et al. (2009) suggested a transitional magmatic arc source affinity and a north/northeast paleocurrent which suggests a southern magmatic arc source.

Sandstone petrography point-counting results from Johnson (1991) and Catuneanu and Elango (2001) indicate the evolving magmatic arc to the south of the CFB was a primary source for Karoo Supergroup sandstones. These studies (Johnson, 1991; Catuneanu and Elango, 2001; Katemaunzanga et al., 2009) also suggest that the fine-grained nature of sediments within the Tanqua and Laingsburg sub-basin is likely due to long transportation distance $(\sim 1000 \mathrm{~km})$ from the source terrane to the basin.

Recent studies indicate that the southern magmatic arc was a major contributor of sediment to Karoo Supergroup sandstones; however the CFB may still be a sediment source due to subaerial exposure during deposition. By using detrital zircon geochronology, the age signature of the Cape Supergroup and other source terranes can be detected. This study will determine the provenance Permo-Triassic Karoo basin-fill, specifically, the middle Ecca Group (Skoorsteenberg, Laingsburg, and Ripon Formations), Upper Ecca Group (Waterford Formation), and lower Beaufort Group (Abrahanmskraal and Koonap Formations) as well as the maximum depositional age of each unit in order to constrain the timing of deposition into the Karoo basin. Provenance will be determined using U-Pb detrital zircon geochronology, sandstone petrography, and heavy/dense mineral composition data. Determining provenance will allow a better overall understanding of the Cape Fold Belt/Karoo basin system by 
providing age constraints on basin-fill, source terrane location and sediment pathways, and relative sediment contribution from source terranes. Through integration of these data, this study can establish if the timing of deposition of Karoo basin-fill coincided with CFB uplift and active arc magmatism, as well as constrain maximum depositional age of Karoo Supergroup units. 


\subsection{Potential Sediment Sources}

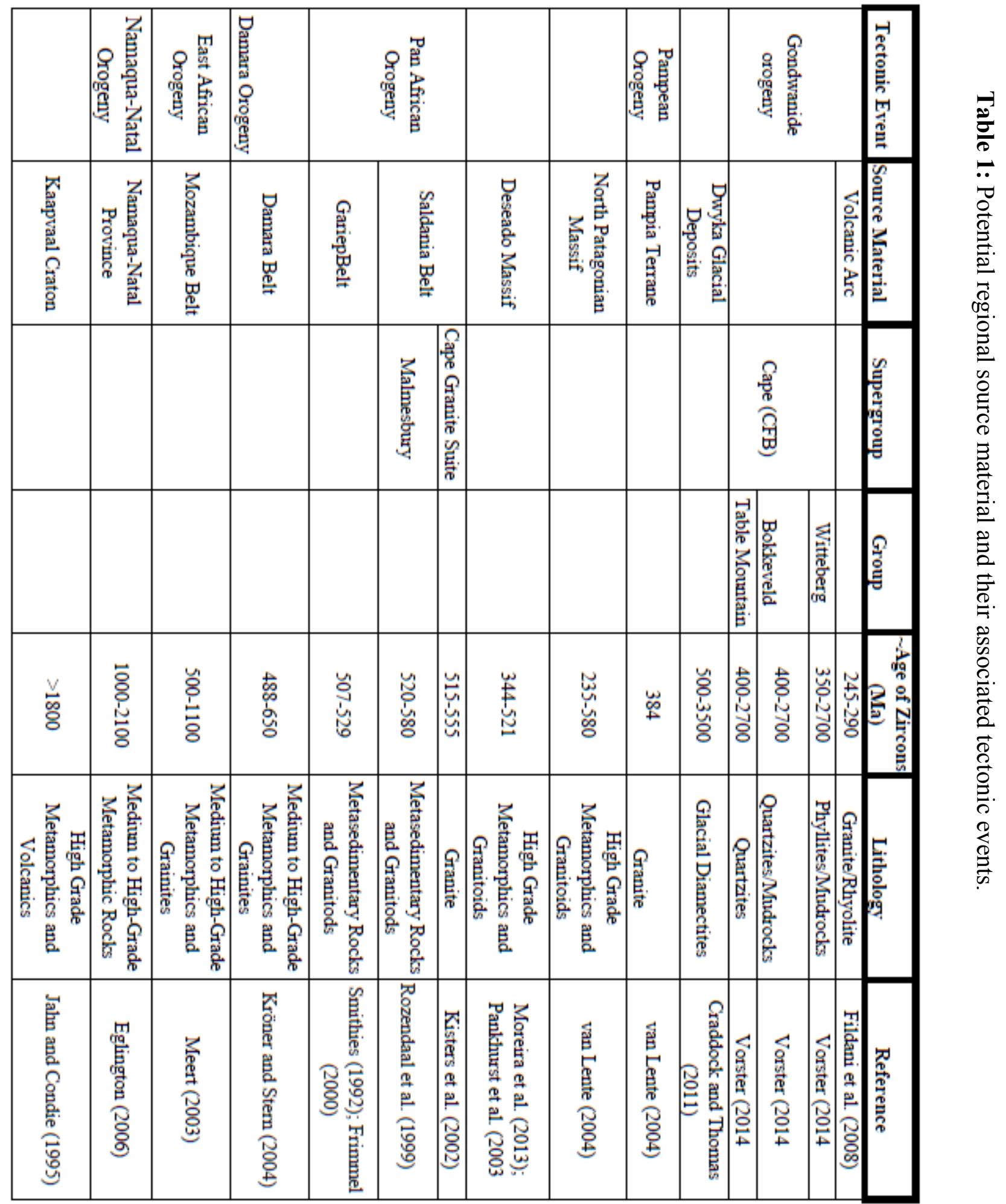




\subsubsection{Southern Magmatic Arc}

The active magmatic arc that developed along the Panthalassan margin may have served as a significant sediment source for Karoo basin fill (Fig. 1) [Anderrsson et al., 2004; van Lente, 2004; Fildani et al., 2007]. The Choiyo magmatic province is a remaining remnant of the magmatic in South America along with geochemically similar tuffaceous material found in the Parana basin of South America and Karoo basin of South Africa [Lopez-Gamundi, 2006]. Arc magmatism is thought to have occurred along the southern Gondwanan margin for approximately $50 \mathrm{Ma}(250-300 \mathrm{Ma})$ with the highest frequency of airfall ash zircons from the Parana and Karoo basins occuring between 250-290 Ma, denoting peak volcanism [LopezGamundí, 2006; Fildani et al., 2007]. Airfall ashes found in the Ecca and Lower Beaufort Groups are thought to be sourced from the magmatic arc because they are geochemically similar and coeval. Magmatism characterized by granite intrusions in the North Patagonian massif occurred between $281 \mathrm{Ma}$ and $294 \mathrm{Ma}$ [Pankhurst et al., 2006]. These rocks were also likely associated with the Choyoi magmatic province of South America which were produced as a result of subduction and continental collision [Lopez-Gamundí and Rossello, 1998]. Rocks associated with arc magmatism are likely either dissected or a part of the submerged continental margin which was the result of Pangaean rifting but could have been subaerial during Gondwanide orogenesis and a potential source for the South African Karoo basin-fill.

\subsubsection{Dwyka Group}

The Late Carboniferous to Early Permian Dwyka Group is the lowest unit of the Karoo Supergroup and consists of glacially-derived sediments deposited during the (Fig 2) [Visser, 1996]. Dropstones consist mainly of granite basement fragments and Proterozoic and Paleozoic quartzites which were likely derived from underlying bedrock (Carboniferous- 
Ordovician Cape Supergroup, Cape Granite suite, and/or Mesoproterozoic Namaqua-Natal metamorphic province) as well as minor components of dolomites, chert, porphyries, and banded iron stones [Johnson et al., 2006; Hambrey and Harland, 2011].

Detrital zircon age populations present within the Dwyka Group sampled from the western southwestern portion of the Karoo basin mainly range from 350-3300 Ma which closely resembles detrital zircon populations present in the Cape Supergroup (see 1.5.3) due to its extensive exposure during glaciation (Fig. 12) [Vorster, 2013]. Dominant zircon age populations within the Dwyka Group range from 450-700 Ma and 950-1300 Ma reflecting provenance from extensive late Neoproterozoic PanAfrican mobile belts surrounding the Kalahari Craton such as the Namaqua-Natal metamorphic province and Saldania belt and Paleozoic sediments such as the Cape Supergroup (Fig. 12)

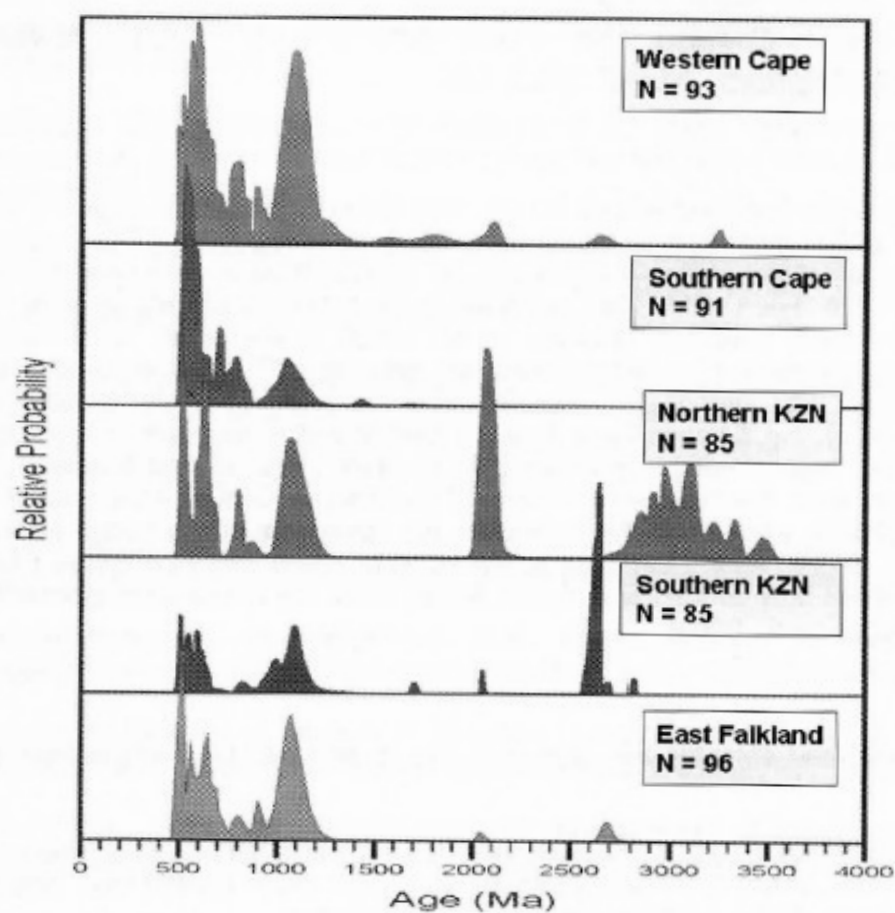

Figure 12: Normalized relative probability density plots of published Dwyka Glacial Group samples from various locations (KZN= Kwa-Zulu Natal) [from Craddock and Thomas 2011].

[Craddock and Thomas, 2011].

\subsubsection{Cape Supergroup}

The Cape Supergroup consists of three groups, the Table Mountain Group, Bokkeveld 
Group, and Witteberg Group. These groups were deposited as passive margin sediments in the early Paleozoic (CarboniferousDevonian) Cape Basin [Veevers et al., 1994; Vorster, 2013] (Fig. 7 \& 8). The depositional age of the Cape Supergroup has been interpreted using fossil analysis. Based on Cruziana trace fossils found in the Table Mountain Group, deposition may have begun around $470 \mathrm{Ma}$ [Broquet, 1992; Shone and Booth, 2005; Thamm \& Johnson, 2006; Fourie et al., 2010] (Fig. 13). Deposition of the Cape Supergroup persisted for $\sim 100$ Ma, ending around 330-350 Ma [McCarthy and Rubidge, 2005]. These strata were then later uplifted to form the Cape Fold Belt as the result of the Cape Orogeny (Gondwanide Orogeny).
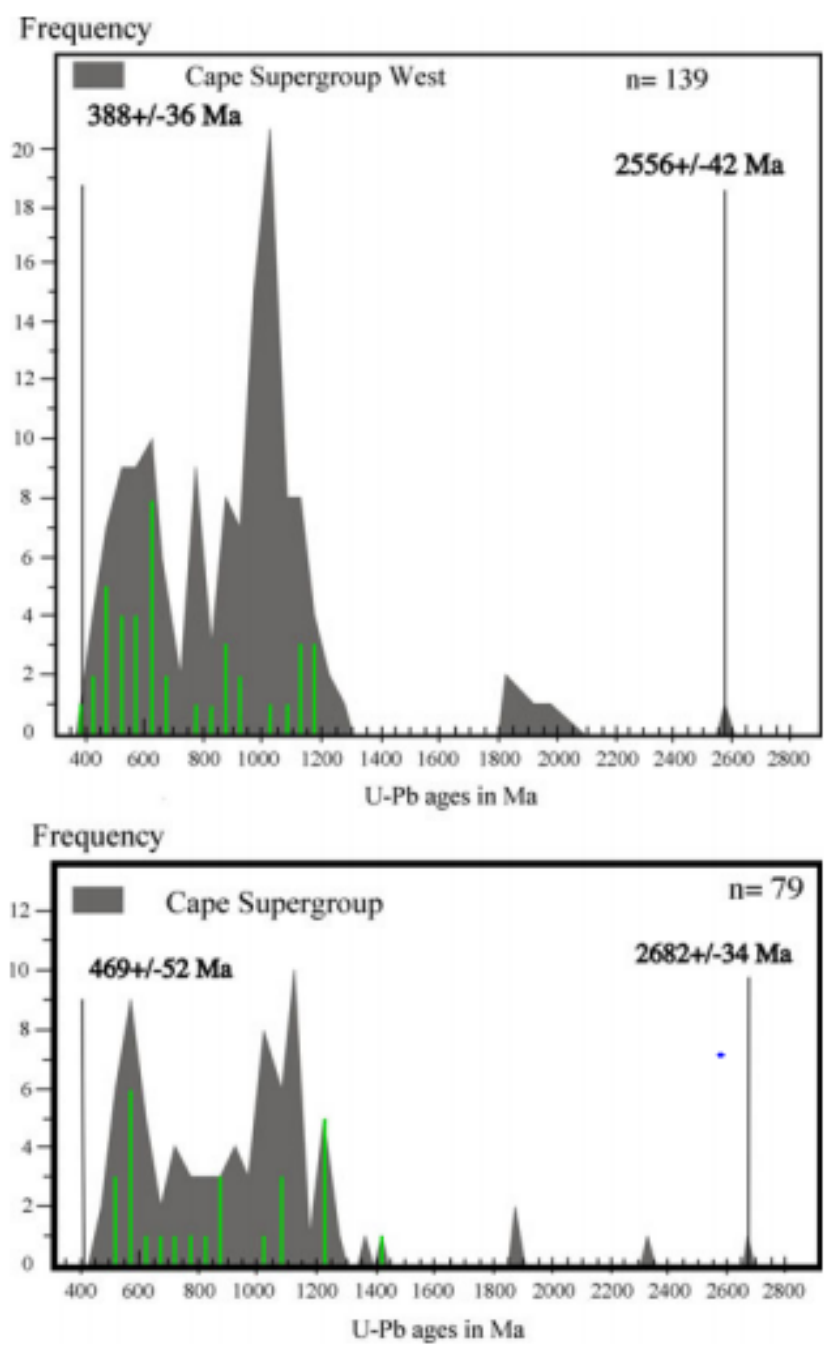

Figure 13: Relative probability density curve of Cape Supergroup detrital zircons [from Fourie et al., 2010].

The Table Mountain Group is composed primarily of quartzite whereas the Bokkeveld and Witteberg Groups consist mainly of phyllite and interbedded quartzites [Veevers et al., 1994]. Compositional maturity of the Cape Supergroup units ranges from supermature quartz arenite of the Table Mountain Group to predominately argillaceous material with thin interbedded quartz arenite of the Bokkeveld and Witteberg Groups [Veevers et al., 1994]. 
Textural maturity throughout the Cape Supergroup is relatively mature.

Zircon ages within the Cape Supergroup range from 380-2700 Ma with dominant populations between 400-650 Ma and 900-1300 Ma [Fourie et al., 2010]. The Cape Granite Suite, Namaqua-Natal metamorphic province and other metamorphic/mobile belts surrounding the Kalahari Craton are present to the North of the Karoo basin, and therefore are potential sediment sources of the Cape Supergroup sediments given the ages of detrital zircon coupled with prevailing southerly paleoflow currents displayed in Cape Supergroup strata [Veevers et al., 1994; Faurie et al.,2010] (Fig. 10a). In general, Cape Supergroup strata contains very little feldspar and lithics either as a result of extensive wave reworking of stable shelf sediments, or due to a sediment source area which had undergone extreme weathering in a low relief cratonic area [Thamm \& Johnson, 2006; Vorster, 2013]. The climate conditions present during the deposition of the Cape Supergroup may have been temperate with ample precipitation causing erosion, accounting for the vast thicknesses of quartz arenite $(2100 \mathrm{~m})$ of the Table Mountain Group [Whittle-Herbert; 1990]. Additionally, the chemical environment may have been slightly acidic, also causing an absence of feldspar.

\subsubsection{Saldania Belt and Gariep Belt}

The Saldania and Gariep Belts are formally referred to as Pan-African fold belts which wrap around the nucleus of the Namaqua-Natal metamorphic province and the Kaapvaal Craton [Veevers et al., 1994]. The Saldania Belt is comprised of the Cape Granite Suite (505$550 \mathrm{Ma}$ ), the low-grade, pellitic metamorphic rock of the Malmesbury Group (metamorphic

age: 520-580 Ma) and other equivalent formations [Rozendaal et al., 1999; Scheepers and Armstrong, 2002]. The Malmesbury Group consists mainly of units such as phyllite [Vorster, 2013]. The Gariep Belt is comprised of mainly metamorphic rocks (hornfels facies) for which 
hornblende and mica ${ }^{40} \mathrm{Ar} /{ }^{39} \mathrm{Ar}$ ages occur between 483-547 Ma. Modern outcrops of the Cape Granite and the Malmesbury Group are isolated along the southern and southwestern portions of southern Africa which makes these rock units candidates as a sediment source for Karoo basin-fill given the northeasterly paleocurrent indicators in Karoo Supergroup strata (Fig. 15) [Veevers et al., 1994].

\subsubsection{Kalahari Craton}

The Kalahari craton of southern Africa consists of the Kaapvaal and Zimbabwe cratons, as well as the Limpopo belt and the Namaqua-Natal province (Fig. 15). The Kalahari craton is a large craton forming a stable unit for the past $2300 \mathrm{Ma}$ [Priestley et al., 2006]. The Kaapvaal craton and Namaqua-Natal province are the southernmost provinces of the Kalahari craton and are the most proximal to the Karoo basin. Northern elements of the Kalahari craton are unlikely sediment sources for Karoo basin due to the north-northeasterly paleocurrent indicators present in the Ecca Group that indicate sediment source rocks were located to the south.

\subsubsection{Namaqua-Natal Belt}

The Namaqua-Natal belt is an extensive metamorphic belt spanning across the African continent (Fig. 15). The Namaqua-Natal belt was formed during the Neoproterozoic to Mesoproterozoic Namaqua- Natal Orogeny and is composed primarily of high grade, mafic to intermediate gneisses and granitoids [Eglington, 2006; McCourt et al., 2006]. Major zircon age populations identified in the Namanqua-Natal belt are between 1000-1400 Ma with minor age populations between 1800-2200 Ma [Eglington, 2006] (Fig. 14). 


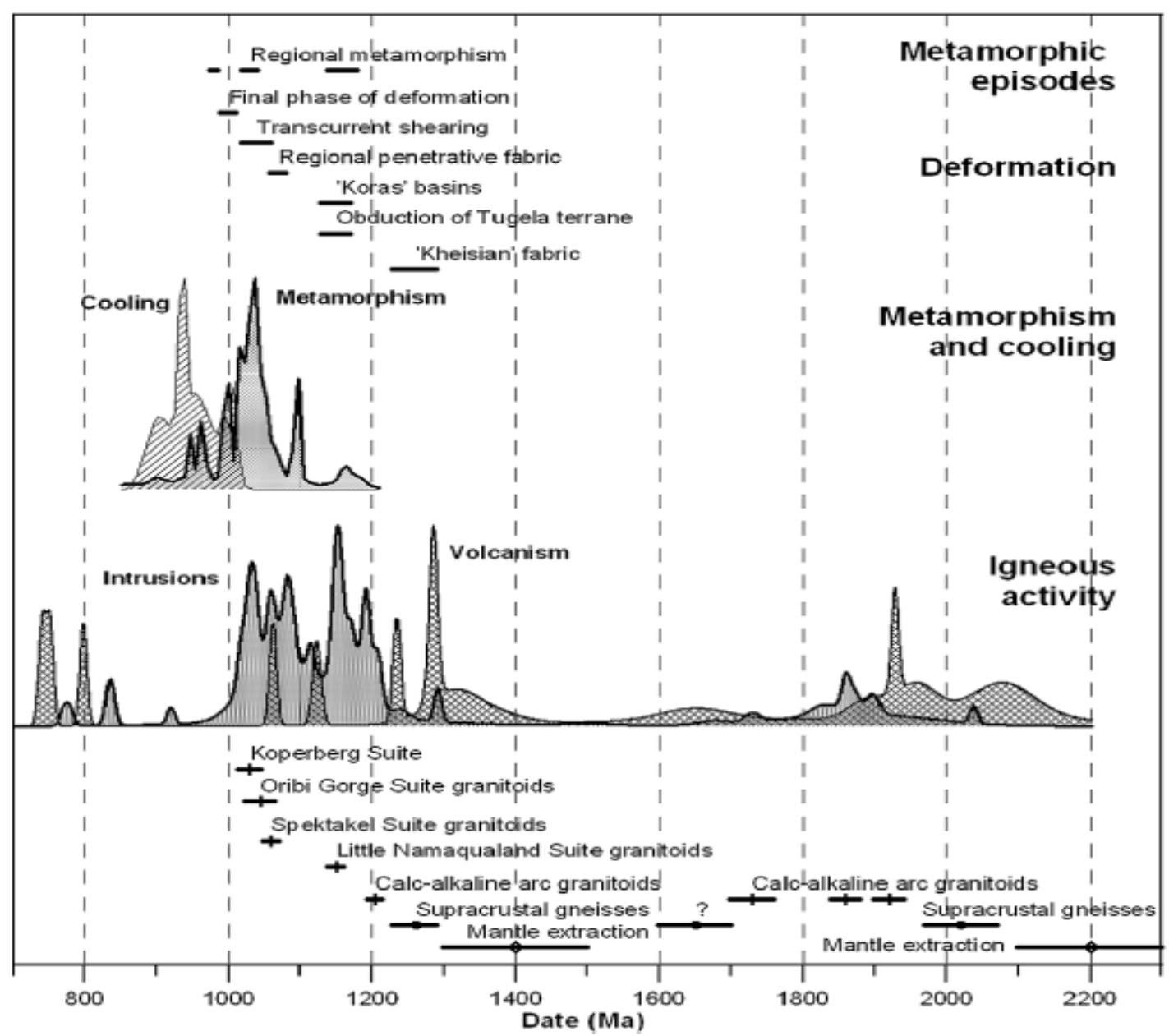

Figure 14: Relative probability density diagram of Namaqua-Natal zircons with tectonic events indicated [from Eglington, 2006]

\subsubsection{Kaapvaal Craton}

The Kaapvaal craton is one of the oldest cratons in the world, forming and stabilizing between 2700 and $3700 \mathrm{Ma}$ (Fig. 15) [De Wit et al., 1992]. The Kaapvaal craton is composed of a mixture of greenstone terranes and tonalitic gneisses as well as intrusive granitic plutons [De Wit et al., 1992]. A study conducted by Poujol et al. (2003) using U-Pb geochronology on zircon, titanite, sphene and monazite reveal ages occurring between 2600-3500 Ma.

\subsubsection{Patagonian and other South American Source Terranes}

Based on paleogeographic reconstructions constructed by Pankhurst et al., (2006), the 
North Patagonian Massif and Deseado Massif were situated along the southern margin of Gondwanna and may have served as potential source terranes for the Karoo basin-fill. It is also possible that impingement of these two fragments upon South Africa may have been responsible for deformation of Gondwanide fold belts which may have persisted into the Mid Permian [Pankhurst et al., 2006]. U-Pb zircon ages from igneous and tuffaceous material of the North Patagonian Massif range from 235-580 Ma whereas igneous ages from the Deseado Massif range from 344- $521 \mathrm{Ma}$ [Pankhurst et al., 2003; van Lente, 2004 Moreira et al., 2013]. An additional source terrane lies to the north of the North Patagonian Massif; the Pampia Terrane. The Pampia Terrane, created by the 520-555 Ma Pampean (Saldanian Orogeny/Cape Granite suite equivalent) orogenic cycles, consists of multiple granitic intrusions [Rapela et al., 2007]. Post orogenic events occur around 384 Ma formed the intrusive Sierra Pampeana granites and may also supply sediment to Karoo basin-fill [van Lente, 2004]. 


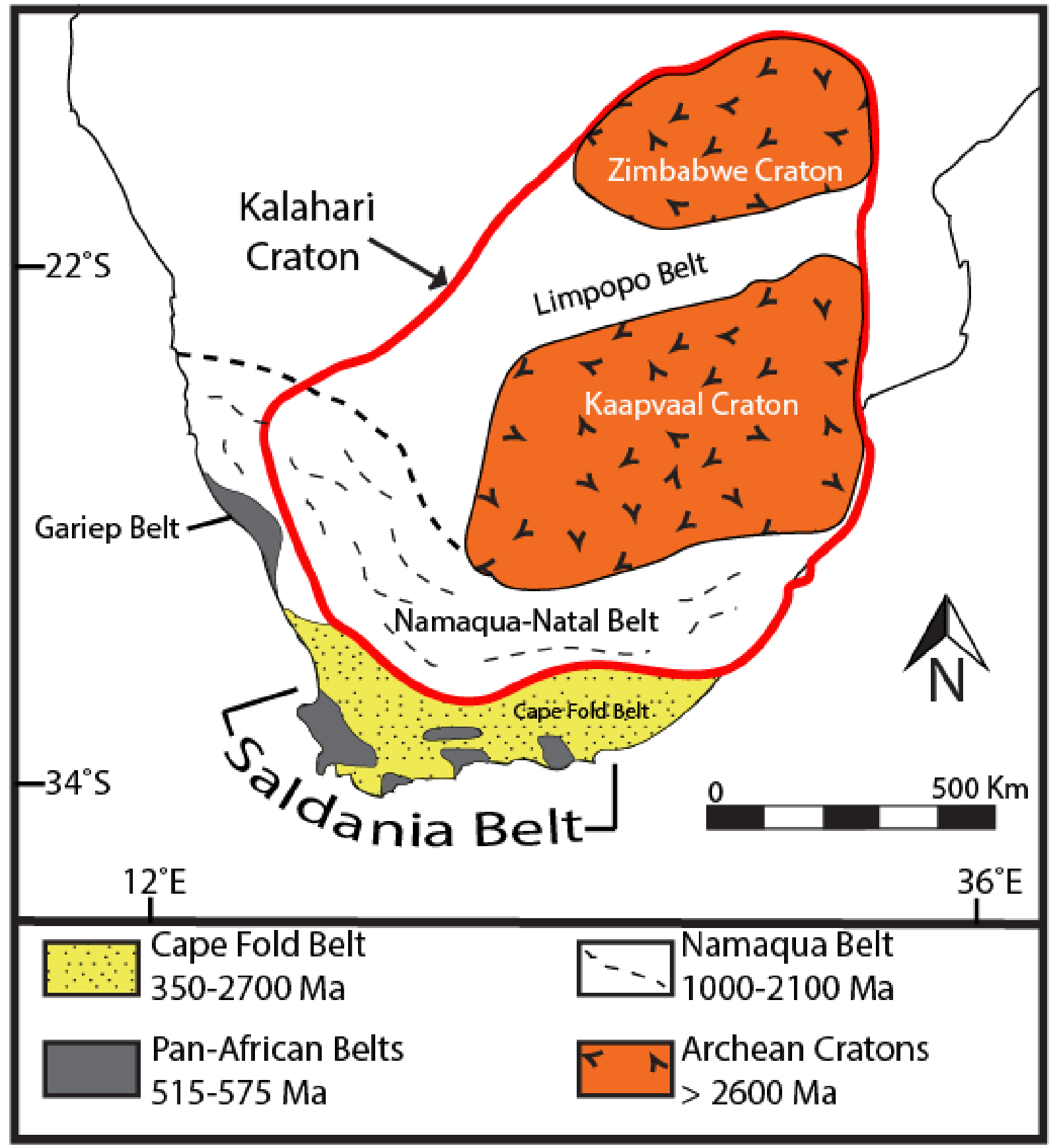

Figure 15: Map of southern Africa outlining possible source terranes for Karoo basin-fill [Redrawn and modified from Kisters et al. (2002) and Priestley et al. (2006)]. 


\section{Chapter II: Methodology}

\subsection{Sampling}

A total of seventeen sandstone samples were collected from seventeen outcrops of (Permian to Triassic age) submarine turbidite fans, deltaic deposits and fluvial deposits. One sample was collected from the Waterford Formation in the Tanqua sub-basin, eleven samples were collected from the Laingsburg (six samples) and Waterford (two samples) Formations and Beaufort Group (three samples) in the Laingsburg sub-basin, and six samples were collected from the Ripon (two samples) and Waterford (two samples) Formations and Beaufort Group (one sample) in the Ripon sub-basin (Fig. 16 \& 17). Eighteen samples were made into thin-sections from whole, unprocessed rock for point-counting framework grain composition, seven of the sandstone samples were processed for U-Pb detrital zircon geochronology, and the disaggregated dense mineral fraction was separated from fifteen of the sandstone samples after processing and was made into grain-mount thin-sections (Table 2). One sample was collected per outcrop and samples were collected based on the least weathered and coarsest grained sandstone bed, which ranged from very fine- to mediumgrained sandstone. These samples were located in the foredeep portion of the Karoo basin proximal to the Cape Fold Belt. Table 2 lists the number of samples and their location as well as which provenance technique(s) were used for each sample. 


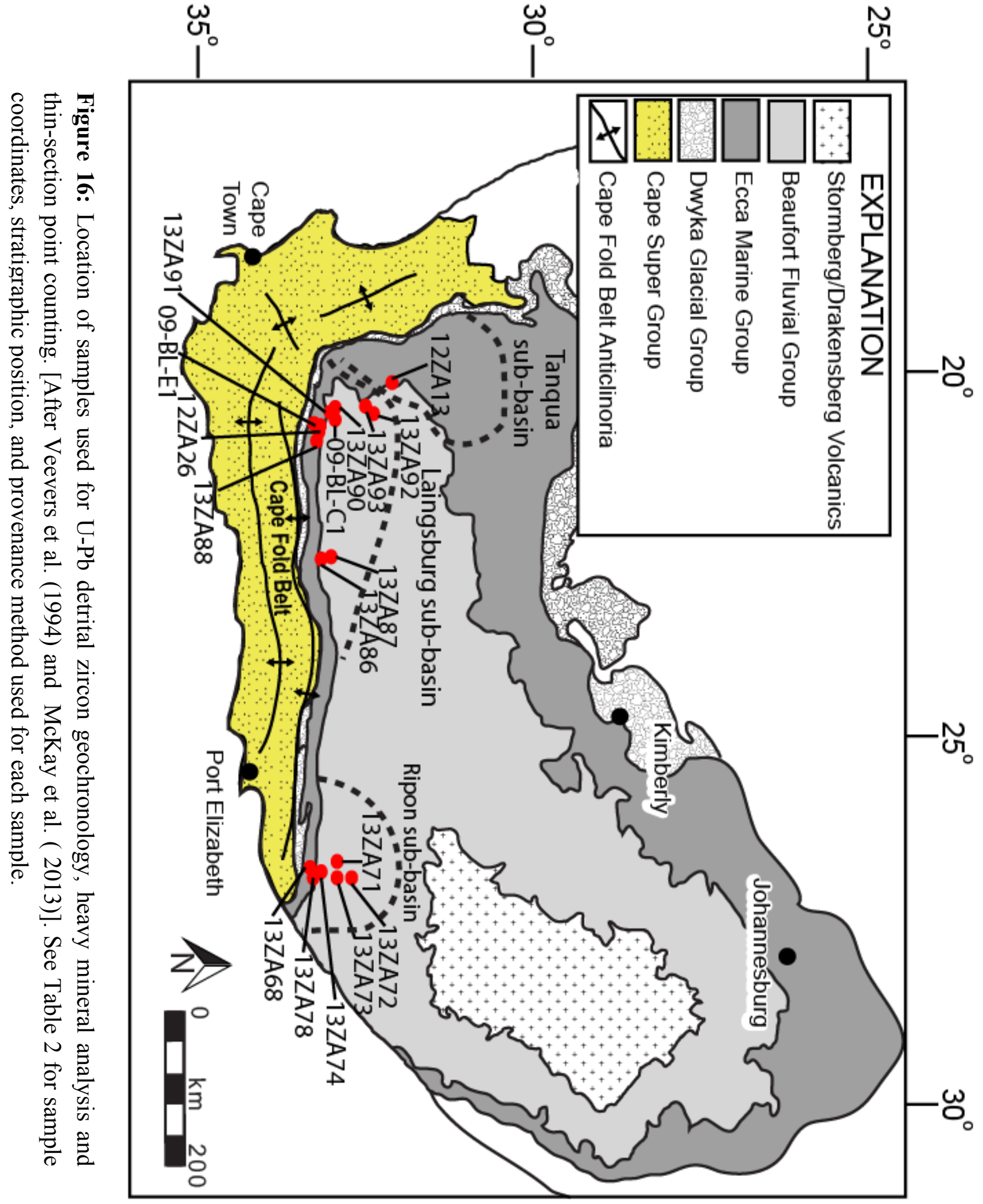




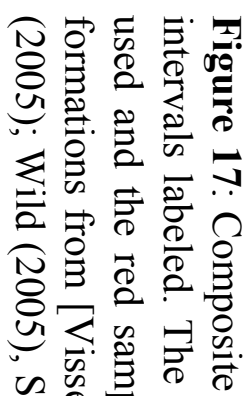

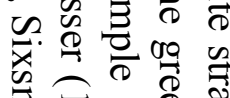

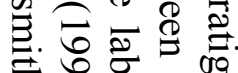

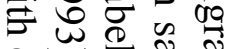

\& ज的

?

กิ๊

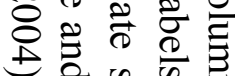

引 $\Omega$ 节 . क

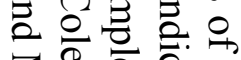

各记蛋

䒕

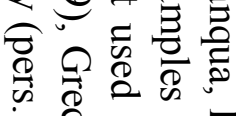

ᄋ 巳

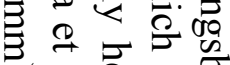

? ब

तิ $<$ वृ

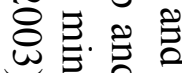

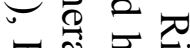

퓨융

员 3

。ㄹ.

$\rightarrow$ के

$\rightleftharpoons \rightarrow$ ڤ

ก릉.

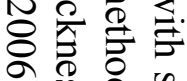

ड़ क क

不造造要

Thickness (m)

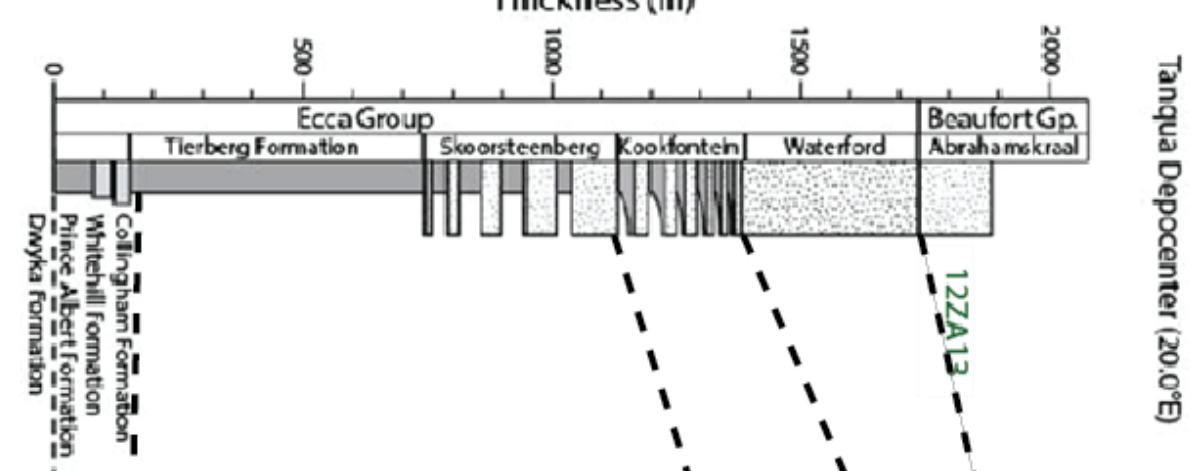




\begin{tabular}{|c|c|c|c|c|c|c|c|c|c|c|c|c|c|c|c|c|c|c|c|c|}
\hline 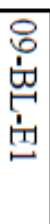 & 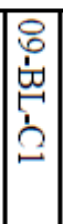 & 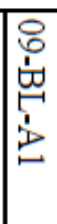 & \begin{tabular}{|l|} 
\\
$w$ \\
$N$ \\
0 \\
0 \\
0
\end{tabular} & $\begin{array}{l}\vec{w} \\
N \\
0 \\
0 \\
0\end{array}$ & 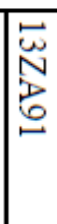 & $\begin{array}{l}\vec{w} \\
\text { N } \\
\text { 号 }\end{array}$ & $\begin{array}{l}\vec{w} \\
N \\
\text { D } \\
\infty \\
\infty\end{array}$ & $\begin{array}{l}\vec{w} \\
\text { N } \\
\text { 点 } \\
\text { - }\end{array}$ & $\begin{array}{l}\vec{w} \\
N \\
\text { D } \\
\infty \\
a\end{array}$ & $\begin{array}{l}\mathrm{N} \\
\mathrm{N} \\
\mathrm{N} \\
\mathrm{a}\end{array}$ & $\aleph_{\infty}^{2}$ & 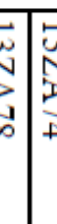 & 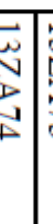 & 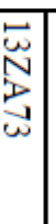 & \begin{tabular}{|l|}
$\vec{w}$ \\
$N$ \\
D. \\
$\mathbf{N}$ \\
\end{tabular} & 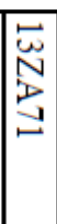 & $\begin{array}{l}\omega \\
\text { w } \\
\text { s } \\
\text { న } \\
\infty\end{array}$ & $\begin{array}{l}\vec{N} \\
N \\
D \\
D\end{array}$ & 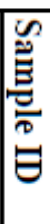 & \\
\hline $\begin{array}{l}\omega \\
\omega \\
\omega \\
\omega \\
w \\
\omega \\
\omega \\
\omega \\
\omega\end{array}$ & 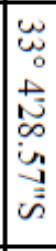 & $\begin{array}{l}\omega \\
\omega \\
0 \\
\omega \\
w \\
w \\
\omega \\
\infty \\
\infty \\
\bar{\omega} \\
\omega\end{array}$ & 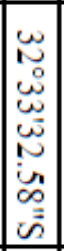 & 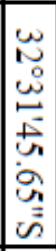 & 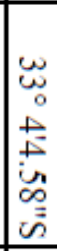 & 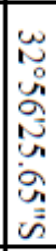 & 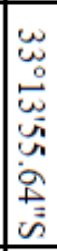 & 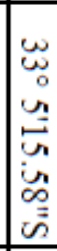 & 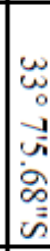 & 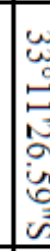 & 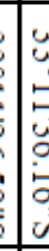 & 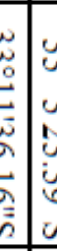 & 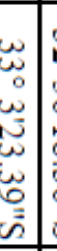 & 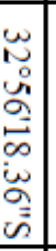 & 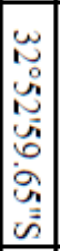 & 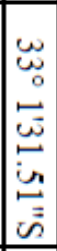 & 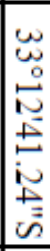 & 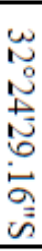 & 昜 & \\
\hline 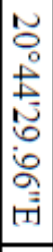 & 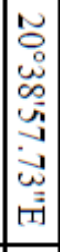 & 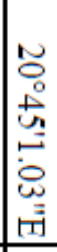 & 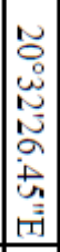 & 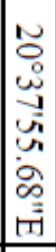 & 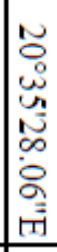 & 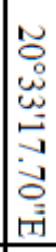 & 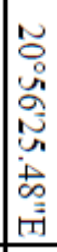 & 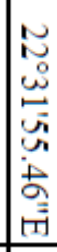 & 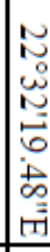 & 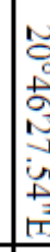 & 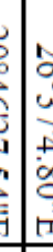 & 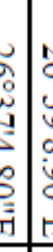 & 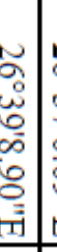 & 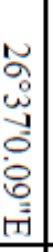 & 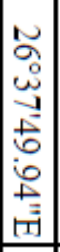 & 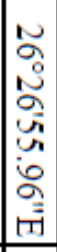 & 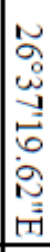 & 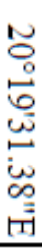 & 点 & \\
\hline 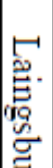 & 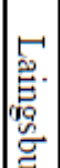 & 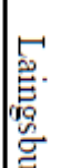 & 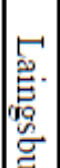 & 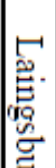 & 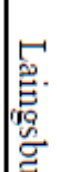 & 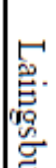 & 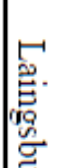 & $\begin{array}{l}\text { D. } \\
\end{array}$ & 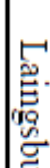 & $t$ & 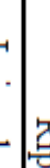 & & & 마. & 只 & & & $\stackrel{\theta}{*}$ & & \\
\hline
\end{tabular}

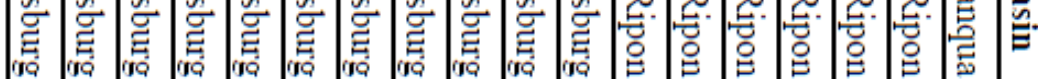

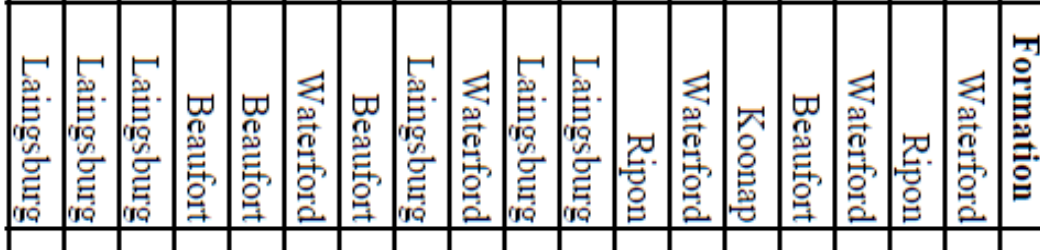

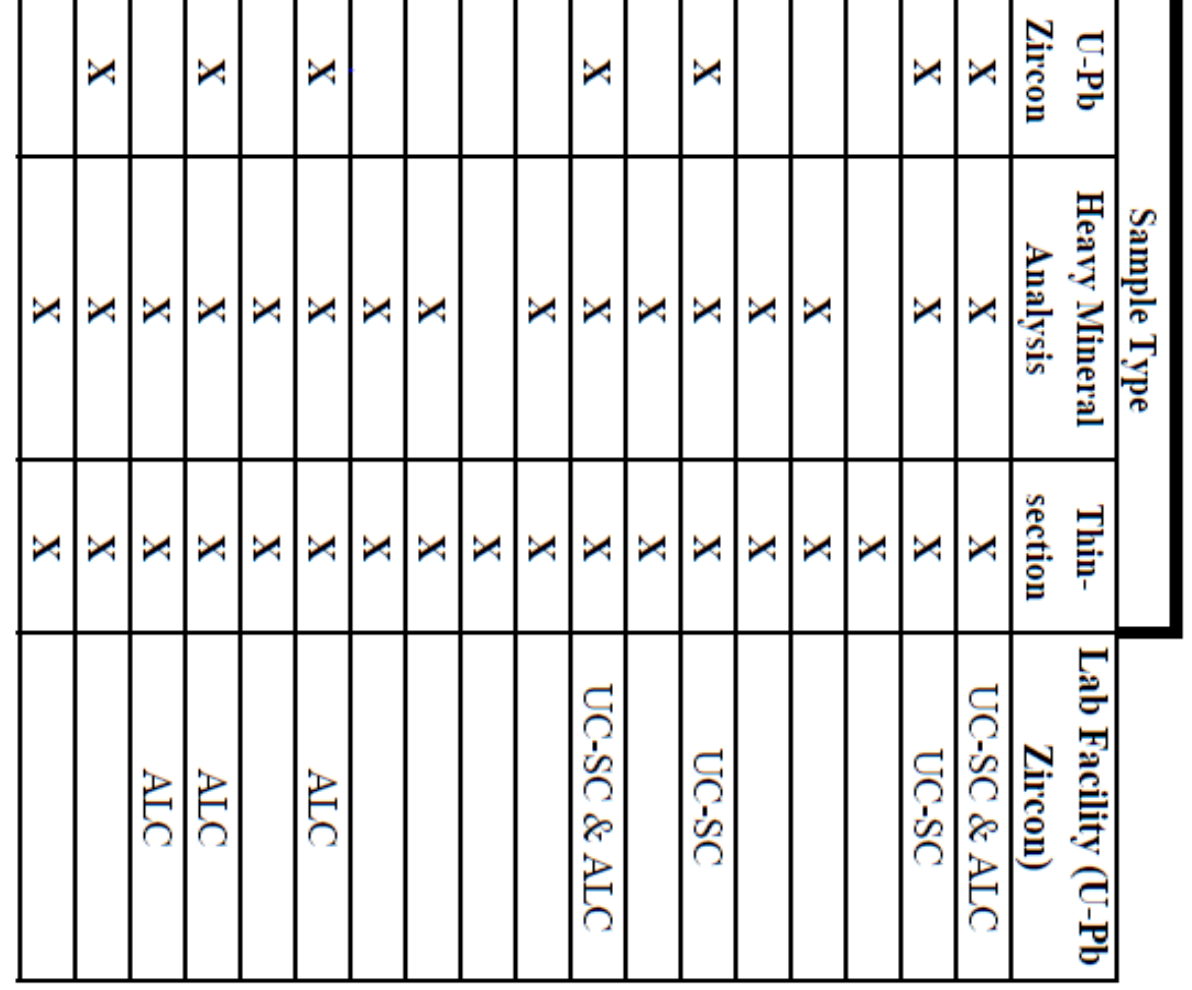


Table 3: Karoo Supergroup sandstone description.

\begin{tabular}{|l|r|r|r|l|l|}
\hline Sample ID & Sub-basin & \multicolumn{1}{|c|}{ Formation } & \multicolumn{1}{|l|}{ Lithology } & Grain Size & Grain Rounding \\
\hline 12ZA13 & Tanqua & Waterford & Sandstone & Very Fine & Sub-rounded \\
\hline 13ZA68 & Ripon & Ripon & Sandstone & Fine-Medium & Sub-rounded to Sub-angular \\
\hline 13ZA71 & Ripon & Waterford & Sandstone & Fine & Sub-rounded \\
\hline 13ZA72 & Ripon & Beaufort & Sandstone & Fine & Sub-rounded \\
\hline 13ZA73 & Ripon & Koonap & Sandstone & Fine & Sub-rounded \\
\hline 13ZA74 & Ripon & Waterford & Sandstone & Fine & Sub-rounded \\
\hline 13ZA78 & Ripon & Ripon & Sandstone & Fine-Medium & Sub-rounded to Sub-angular \\
\hline 12ZA26 & Laingsburg & Laingsburg & Sandstone & Fine & Sub-rounded to Sub-angular \\
\hline 13ZA86 & Laingsburg & Laingsburg & Sandstone & Fine & Sub-rounded to Sub-angular \\
\hline 13ZA87 & Laingsburg & Waterford & Sandstone & Fine & Sub-rounded \\
\hline 13ZA88 & Laingsburg & Laingsburg & Sandstone & Fine & Sub-rounded to Sub-angular \\
\hline 13ZA90 & Laingsburg & Beaufort & Sandstone & Very Fine & Sub-rounded to Well rounded \\
\hline 13ZA91 & Laingsburg & Waterford & Sandstone & Fine & Sub-rounded \\
\hline 13ZA92 & Laingsburg & Beaufort & Sandstone & Very Fine & Sub-rounded to Well rounded \\
\hline 13ZA93 & Laingsburg & Beaufort & Sandstone & Very Fine & Sub-rounded to Well rounded \\
\hline 09-BL-A1 & Laingsburg & Laingsburg & Sandstone & Fine & Sub-rounded to Sub-angular \\
\hline 09-BL-C1 & Laingsburg & Laingsburg & Sandstone & Fine & Sub-rounded to Sub-angular \\
\hline 09-BL-E1 & Laingsburg & Laingsburg & Sandstone & Fine & Sub-rounded to Sub-angular \\
\hline
\end{tabular}

\subsection{U-Pb Detrital Zircon Geochronology}

To reduce each sandstone sample to zircon, each whole rock sample was first crushed into smaller fragments using a jaw crusher. The sample was then pulverized to fine-grained material using a disk mill. The powder was then sieved with a No. 45 mesh sieve $(345 \mu \mathrm{m})$ to remove any remaining large rock fragments. Next the milled material was then separated hydrodynamically using a Gemini table. The heavy fraction from the Gemini table was dried in an oven then separated magnetically using a sloped Frantz magnetic separator. The nonmagnetic fraction was then separated using heavy liquid separation, specifically, lithium polytungstate (LPT) followed by methylene iodide (MEI) to separate out dense minerals.

The dense mineral fraction separated by MEI was then concentrated to primarily zircon by removing other accessory minerals such as barite and apatite with tweezers. The zircons 
were then mounted in one inch diameter epoxy discs. Most samples contained over 100 zircon grains mounted on each disc, however, some grains were removed from the epoxy during polishing and smaller grains were left unexposed due to varying sizes of zircons in nearly all samples. The discs were polished using various sandpapers to expose the zircon grains in the epoxy. Cathodoluminescence (CL) images of zircon grains were collected at WVU using a JEOL scanning electron microscope. The mounts were also imaged with transmitted light using a Nikon Eclipse polarizing microscope to create larger images for grain identification purposes.

This study used Laser Ablation Inductively Coupled Plasma-Mass Spectrometry (LAICPMS) which is an extremely popular and widespread technique for rapid and relatively inexpensive determination of reliable U-Pb zircon ages [Paton et al., 2010]. Data was collected by LA-ICPMS at two different facilities; two samples were analyzed at the University of California at Santa Cruz and five samples were analyzed at the Arizona Laserchron Center at the University of Arizona (Table 2).

At the UC-Santa Cruz facility, zircons were analyzed using a single-collector Thermo ELEMENT 2 ICP-MS coupled with a HelEx sample carrier and Photon Machines laser ablation system. The laser was operated with an output energy of $\sim 40 \mathrm{~mJ}$ per pulse with a 23micron circle [Paton et al., 2010]. Each analysis required a collection time of 30 seconds with a 20 second delay before the next analysis collection to purge the system. The Arizona Laserchron Center (ALC) at the University of Arizona uses a GVI Isoprobe multi-collector mass-spectrometer coupled to a $19 \mathrm{~nm}$ wavelength New Wave Instruments Excimer laserablation system. Detrital zircon grains were analyzed using a 30-micron beam diameter with a pit depth of approximately 15 microns [Gerels et al., 2006]. Each analysis required a 
collection time of 20 seconds with a 30 second delay before the next analysis to purge the system.

Each sample was analyzed using comparison to primary and secondary reference standard zircon grains. The two samples analyzed at the UC-Santa Cruz facility were compared to Plesovice zircon as a primary reference standard which dates $337.2 \pm 0.4$ $\mathrm{Ma}$, and to R33 zircon as a secondary reference standard which dates to $419.3 \pm 0.4 \mathrm{Ma}$ [Black et al., 2004; Slama et al, 2008]. At UC-Santa Cruz, five primary reference standard grains and two secondary reference standard grains were analyzed at the start of each sample session and ended with the analysis of two primary and two secondary standard grains. Two primary reference standard grains were also analyzed after every five unknown analyses until 100 unknown grains were analyzed. At ALC, each sample session started with the analysis of five primary reference standard grains and ended with the analysis of three primary standard grains. Three secondary reference standard grains were analyzed in the middle of the sample session and one secondary reference standard grain was analyzed at the end of the sample session. One primary reference standard grain was also analyzed after every five unknown analyses until 100 unknown grains were analyzed. At the ALC, the SL2 (Sri Lanka) primary zircon reference standard was used which is $563.5 \pm 2.3 \mathrm{Ma}$ (Gehrels et al., 2008) and the R33 secondary reference standard was used.

Data collected at the UC Santa Cruz facility were reduced off-line using the Iolite data reduction package that runs within the Igor Pro data analysis software [Paton et al., 2010]. Each analysis was examined for analyses detecting high ${ }^{204} \mathrm{~Pb}$ and evidence of "drill through", in which the beam totally penetrated the grain during the ablation process. Criteria for rejection were the same for analyses at both labs. Analyses were rejected if high errors ( $>10 \%$ 
uncertainty) of the ${ }^{206} \mathrm{~Pb} /{ }^{207} \mathrm{~Pb}$ and ${ }^{206} \mathrm{~Pb} /{ }^{238} \mathrm{U}$ isotope ratios, high ${ }^{204} \mathrm{~Pb}$, low ${ }^{206} \mathrm{~Pb} /{ }^{204} \mathrm{~Pb}$, high discordance $(>20 \%)$, or reverse discordance $(>5 \%)$ were present. Once data was extracted, reduced and vetted following the protocol of the respective laboratory facilities at which the analyses were performed, all accepted analyses were then used to created concordia diagrams and probability density plots using Isoplot 4, a Microsoft Excel add-in [Ludwig, 2012]. Kernel Density Estimation (KDE) plots were created using a Java application (Density Plotter) [Vermeesch, 2012].

This study aimed to analyze at least 100 grains per mount in order to achieve $95 \%$ certainty that no fraction $\geq 5 \%$ of the population was missed [Vermeesch, 2004]. One sample, 12ZA13, contained $>100$ analyses with a range of 82-110 zircon analyses in the seven $\mathrm{U}-\mathrm{Pb}$ samples. According to this range of analyses, the probability of at least one population ranges between 1-5\% based on the work of Vermeesch (2004).

The plots created from the final reduced data from each lab facility include pie charts, $\mathrm{U}-\mathrm{Pb}$ age versus U/Th cross-plots, probability-density and KDE plots. Probability-density and KDE plots include histograms that display the data in 50 Ma bins. Distinct age populations, two or more grains of the same age, within each sample are represented by the horizontal black bars above the curves. Probability density plots are one of the most widely used tools in the field of detrital zircon geochronology. Probability density plots are produced by summing a set of Gaussian distributions whose mean and standard deviations correspond to the individual age and associated analytical error [Vermeesch, 2012]. Similarly, KDE plots are also produced by summing a set of Gaussian distributions with an associated smoothness factor or bandwidth [Vermeesch, 2012]. The bandwidth of a KDE curve is adaptive such that the bandwidth is adjusted based on local density differences. Adaptive bandwidth uses a large 
bandwidth where the density is low and a narrower bandwidth where the density is high to prevent over- and under-smoothing in high and low density portions of the curve.

The bandwidth (KDE) for each sample was set to adaptive in the Density Plotter application to prevent over- and under-smoothing. Adaptive bandwidth allows the bandwidth to vary due to local density differences [Vermeesch, 2012]. U-Pb age populations were defined by two or more grains of the same age. Pie charts of reliable ages were created to determine the relative abundance of each population within each sample. U-Pb age versus $\mathrm{U} / \mathrm{Th}$ plots were created to determine whether detrital zircons are metamorphic or igneous in origin. The U/Th of metamorphic and igneous zircons can be significantly different due to the larger ionic radius of $\mathrm{Th}^{4+}$ compared to $\mathrm{U}^{4+}$; thus, $\mathrm{Th}^{4+}$ is preferentially purged from the zircon crystal during metamorphism, resulting in a larger U/Th compared to igneous zircon. Igneous zircons tend to have a $\mathrm{U} / \mathrm{Th}<2$ but in rare circumstances can reach up to 5 or greater [Hoskin and Schaltegger, 2003]. Therefore, zircon with $\mathrm{U} / \mathrm{Th}>4$ are considered to be likely metamorphic in origin.

\subsubsection{Maximum Depositional Age}

One of the most widely used applications for detrital zircon geochronology is determining the maximum depositional age. For this study, we use the five methods discussed by Dickinson and Gehrels (2009) which include: a) youngest single-grain age (YSG); b) youngest graphical (probability density plot) age peak controlled by more than one grain age (YPP); c) mean age of the youngest two or more grains that overlap in age at $1 \sigma(\mathrm{YC} 1 \sigma)$; d) mean age of the youngest 3 or more grains that overlap in age at $2 \sigma(\mathrm{YC} 2 \sigma)$; e) youngest detrital zircon age (YDZ) generated by Isoplot 4 [Ludwig, 2012]. Other methods that can be applied using Isoplot 4 include the weighted mean age and Tuff Zirc age (Ludwig and Mundil, 2002) as well as Unmix 
age which are generally not used for detrital zircon data sets. Tuff Zirc ages are not determined for detrital zircon data sets because there is no way to control the basis for which grains are rejected from the population, whereas Unmix age routine is not usedbecause the two youngest age populations are averaged, creating a new, smoothed age distribution.

Each method used to determine the maximum deposition varies in accuracy and reproducibility. The YSG method may be misleading because a single data point in an analytical matrix may be spurious and susceptible to lead loss [Dickinson and Gehrels, 2009]. Similarly, the YDZ method, calculated using the Isoplot plugin, provides ages similar to that of the YSG method thus, this method may be inaccurate due to the susceptibility to lead loss and lack of reproducibility. The YPP method provides reliable age estimates for the youngest age within a sample but may yield an older overall age than that of the true depositional age. The YC1 $\sigma$ and YC2 $\sigma$ methods are the most statistically robust and conservative methods at determining the maximum depositional age but may produce ages that are $10 \mathrm{Ma}>$ than the depositional age [Dickinson and Gehrels, 2009].

\subsubsection{Kolmogorov-Smirnoff Test}

In order to compare provenance similarities from sample to sample and similarities to published regional source zircon data, Kolmogorov-Smirnoff Tests (K-S Test) or goodness-of-fit tests were conducted using a Java application (Density Plotter) [Vermeesch, 2012]. This test provides a statistical basis for the similarity of samples [Press et al., 1986]. K-S tests were only performed on the prominent age population (240-300 Ma) within each sample due to the insensitivity of the K-S test to dispersed data, thus, comparing two separate age populations would yield no statistical similarities [Press et al., 1986]. To perform K-S tests, a Cumulative 
Density Function (CDF) of ages is used to determine the statistical similarity of two or more age populations. Two samples are considered statistically similar if their corresponding probability (p)-values exceed 0.05; thus a 95\% confidence level can be established that two samples are statistically similar or from the same parent rock. Poorly characterized samples (e.g., Vermeesch, 2004; Andersen, 2005) can yield spuriously small p-values, particularly if a zircon age population is absent, over-represented, or under-represented in a sample distribution. Adequate characterization of complex of zircon age distributions may require hundreds of single grain ages [Andersen, 2005]. Overall, polymodal samples are more likely to be poorly characterized as opposed to unimodal samples that can be easily compared to one another. The Permian/Triassic age population in samples collected in this study were compared to each other to determine their statistical similarities.

\subsection{Sandstone Petrography}

Sandstone petrography and thin-section point-counting is a powerful tool used to describe and quantify rock composition in an unbiased manner. This method was used in this study to supplement the detrital zircon U-Pb age data as a provenance indicator. A total of 17 thin-sections were point counted using a Conwy Valley automated point-counting stage with a step-size ranging from 1.5 to 3 times the average grain size. Sandstone samples point-counted include one from the Tanqua sub-basin, six from the Ripon sub-basin, and 10 from the Laingsburg sub-basin. This study uses the Gazzi-Dickenson point-counting method to reduce the effects of grain-size biases on composition by only identifying the composition of the sand-sized components in a given sample [Ingersol et al., 1984]. A total of 400 point-counts were obtained for each thin-section to achieve a maximum error of $5 \%$ at $2 \sigma$ [Van Der Plas and Tobi, 1965]. The resulting framework grain estimations from point-counting were then 
plotted on various provenance ternary plots after Dickinson and Suczek (1979) to determine the tectonic setting from which Karoo sandstones were derived.

\subsection{Heavy Mineral Analysis}

Identifying accessory minerals in sandstones, specifically minerals denser than quartz $\left(2.9 \mathrm{~g} / \mathrm{cm}^{3}\right)$, may indicate the tectonic setting from which Karoo sands were derived [Mange and Maurer, 1992]. Dense/heavy mineral analysis was conducted following the methods used by Lisi (2013). Disaggregated rock material from the heavy fraction of each sample including the magnetic fraction, LPT heavy fraction, MEI light fraction and unmounted zircon left-overs from the MEI heavy fraction were all mixed back together after zircon grains were extracted for U-Pb dating. The LPT and MEI heavy fractions contained all heavy minerals present in the sample with the exception of zircon used for $\mathrm{U}-\mathrm{Pb}$ analysis. These grains were then made into polished grain mounts. The grain mounts contained large quantities of quartz and feldspar which made point-counting heavy minerals difficult. To count heavy minerals, all heavy minerals we counted in a single field of view under a 10X microscope frame [e.g., Lisi, 2013]. The process was repeated until 50 grains were counted.

\section{Chapter III: Results}

\subsection{U-Pb Sample Descriptions and Age Populations}

A total of 632 reliable zircon grains were obtained from seven disaggregated sandstone samples. Samples are presented from oldest to youngest in each section and work though sections from east to west. 
12ZA26: Laingsburg Formation
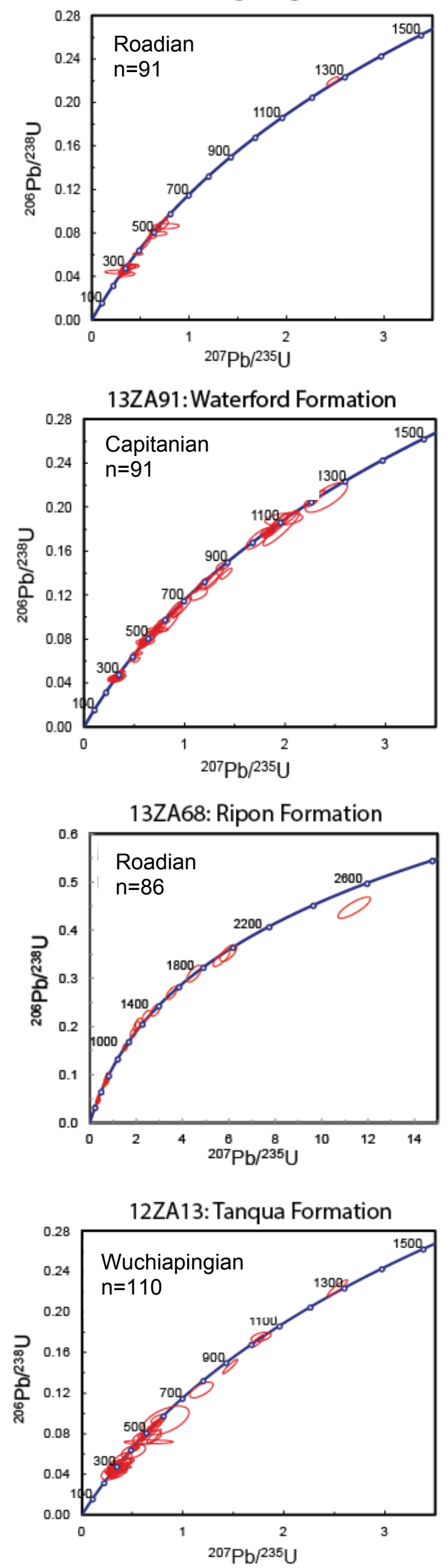
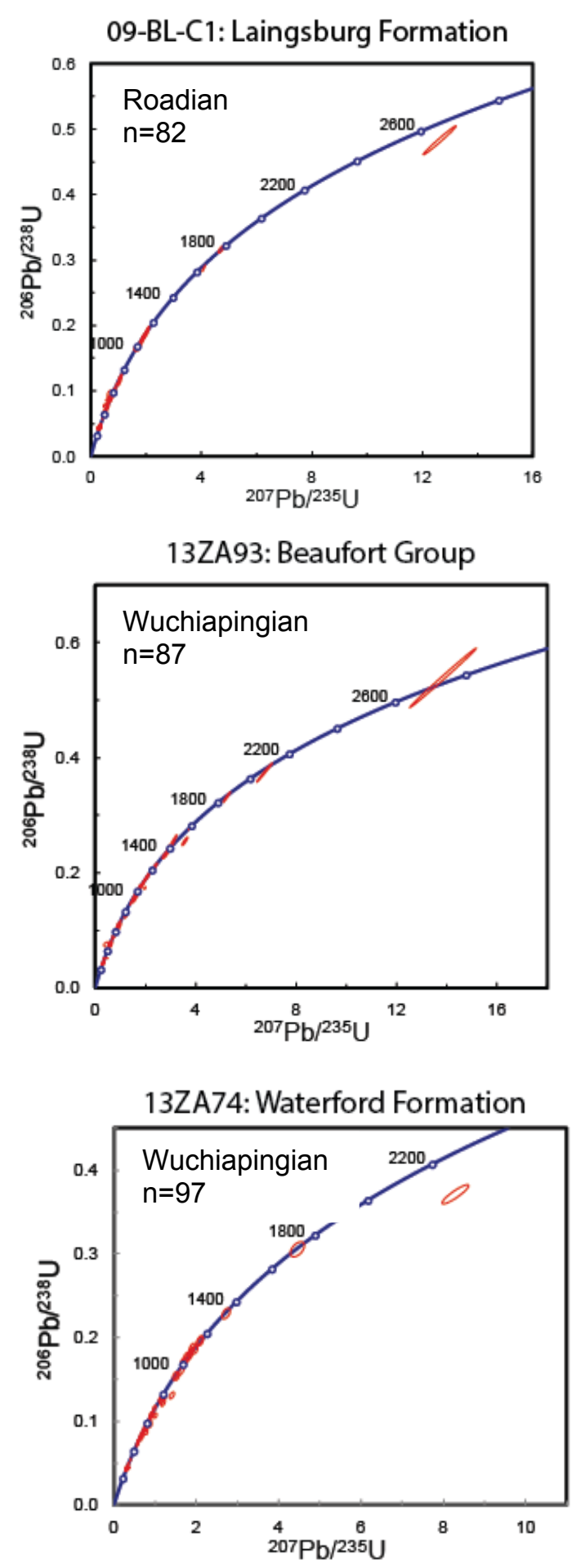

Figure 18: $\mathrm{U}-\mathrm{Pb}$ Wetherill concordia plots of all analyses for all seven detrital zircon samples. The red ellipses represent the analyzed grains in each sample which includes an internal 2-sigma error. Each sample is labeled with its approximate stratigraphic age and the number of accepted grains (n). 

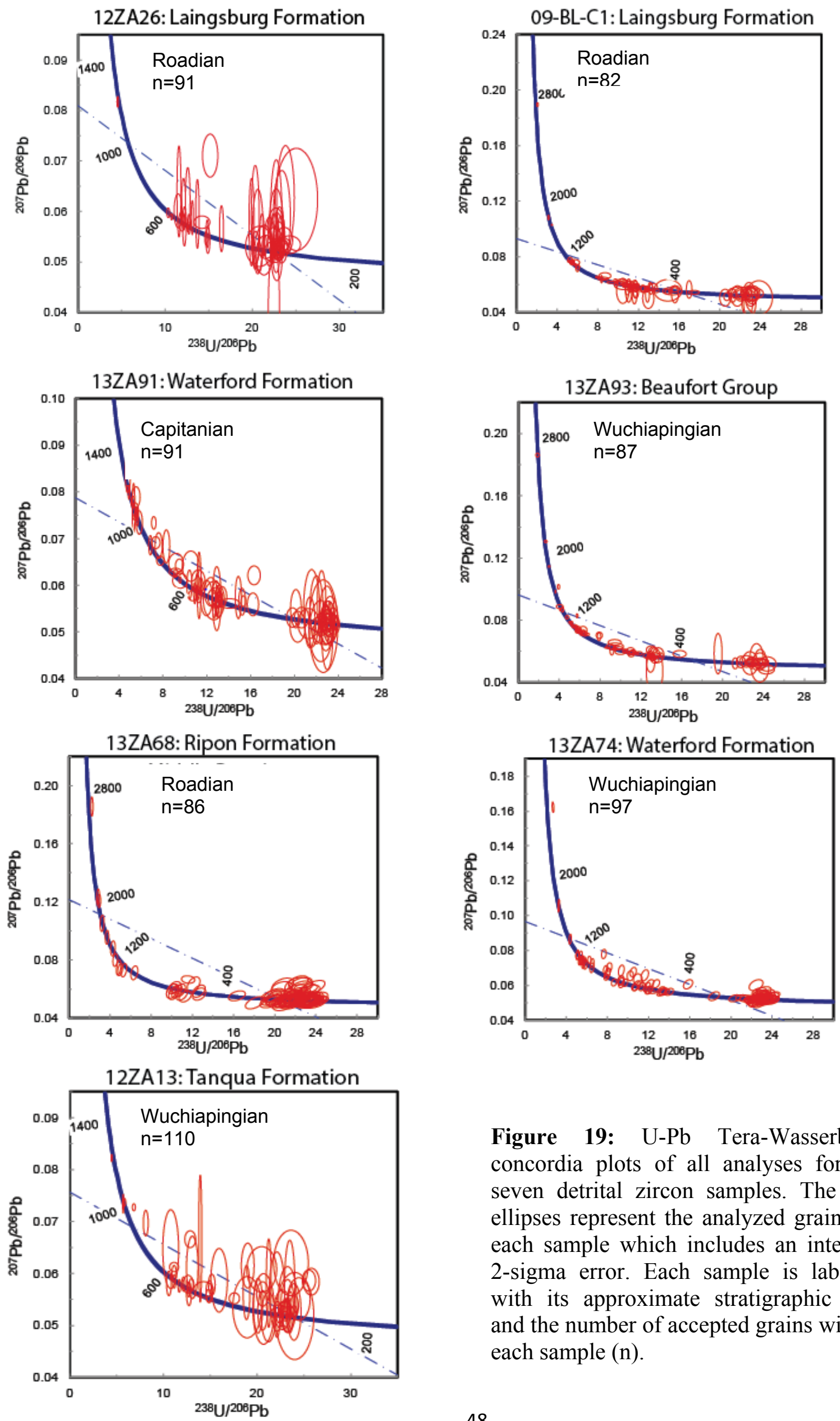

Figure 19: U-Pb Tera-Wasserberg concordia plots of all analyses for all seven detrital zircon samples. The red ellipses represent the analyzed grains in each sample which includes an internal 2-sigma error. Each sample is labeled with its approximate stratigraphic age and the number of accepted grains within each sample (n). 


\subsubsection{Sample 12ZA13: Waterford Formation}

Sample 12ZA13 was taken from the Late Permian (Wuchiapingian) Waterford Formation of the Upper Ecca Group in the Tanqua sub-basin (Fig. 16 \& 17). The depositional age (255 Ma) determined by Rubidge (1991) is based on a Wuchiapingian aged reptilian fossils assemblage found in the lower Beaufort Group. The Waterford Formation is interpreted as deltaic deposits within the uppermost Ecca Group [Johnson et al., 1996]. The outcrop consisted of thin- to thick-bedded, upwardcoarsening sandstones interbedded with thin siltstone and mudstone layers. Tangential cross-beds and bi-directional ripple laminations were prominent throughout the outcrop. Cruziana-Skolithos trace

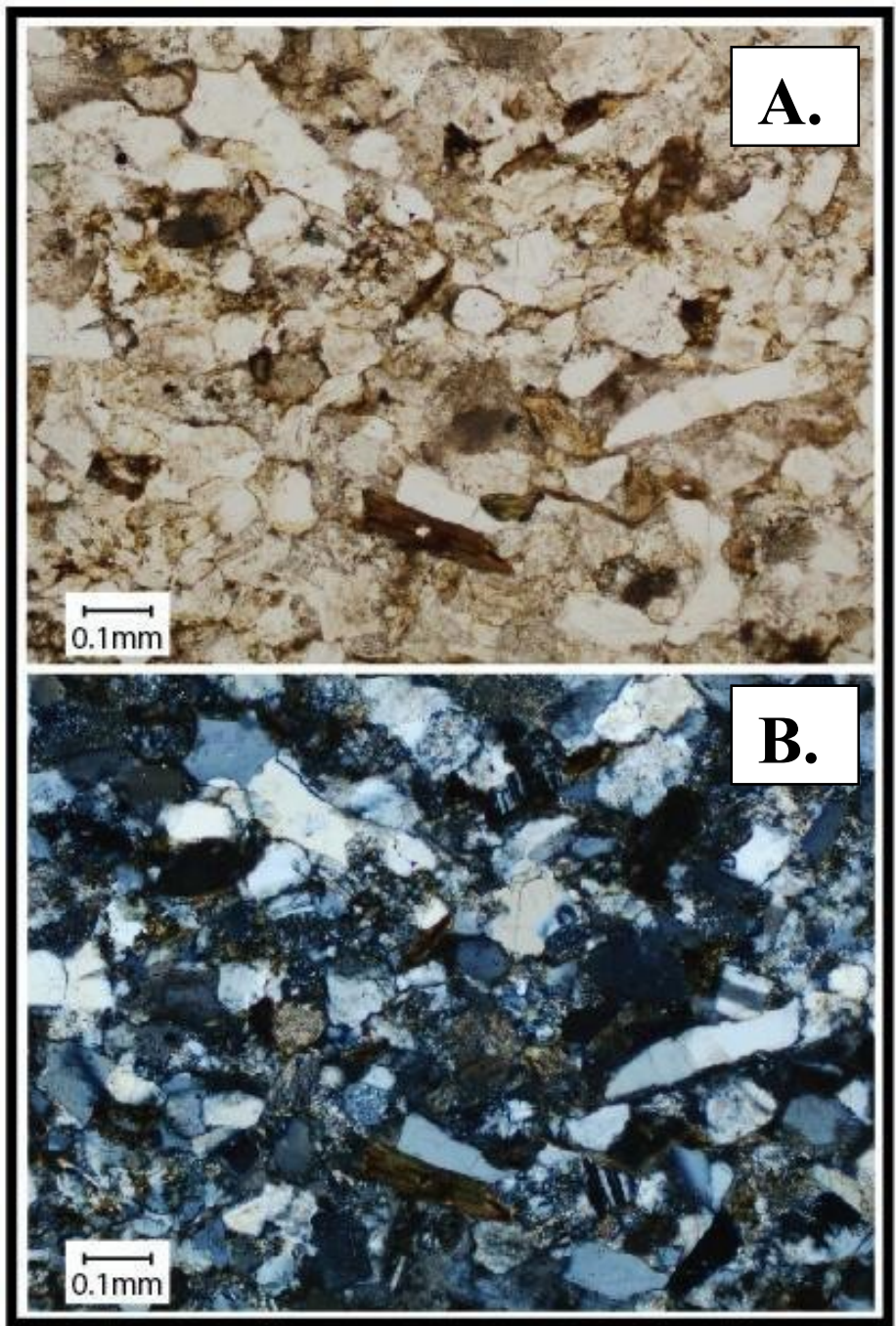

fossils were present in most sandstone layers. Overall the outcrop was relatively unaltered with slightly Figure 20: Thin-section image of sample 12ZA13 in plain light (A) and cross-polarized light (B). The sample consists of moderately to well-sorted, angular to sub-angular, fine-grained sandstone.

weathered surfaces appearing orange/brown and unweathered surfaces appearing light tan. The sample consisted moderate to well sorted, angular to sub-angular, fine- to medium-grained sand. 
Wavy bedding and cross-laminations were present in the hand sample. The depositional environment of the sampled portion of the Waterford Formation was likely a fluvially dominated delta in the delta plain portion of the system based on the interbedded nature of the outcrop, trace fossils present, and bi-directional flow patterns. Sandstone composition was relatively immature, with moderate quartz and abundant lithics and feldspar (Fig. 20). Sample 12ZA13 yielded abundant zircon (several hundred to thousands). Zircon grains were prismatic, transparent/colorless to slightly yellow, and ranged in size from 10-50 $\mu \mathrm{m}$.

A total of 169 zircon grains were analyzed from sample 12ZA13, with 99 grains analyzed at the UC-Santa Cruz lab facility and 70 grains analyzed at ALC lab facilities. Analysis of sample 12ZA13 yielded 110 reliable ages. A total of 59 ages were rejected, with 51 ages rejected due to discordance, five ages rejected due to high ${ }^{204} \mathrm{~Pb}$ concentration, two ages rejected due to high ${ }^{206} \mathrm{~Pb} /{ }^{238} \mathrm{U}$ error, and one age rejected due to $10 \mathrm{w}{ }^{206} \mathrm{~Pb} /{ }^{204} \mathrm{~Pb}$ isotope ratio. Ages within this sample range from $245.4 \pm 6.5 \mathrm{Ma}$ to $1250.5 \pm 12.5 \mathrm{Ma}$ (Fig. 21A). In general, all ages fall within three distinct age populations which range between $245.4 \pm 6.5 \mathrm{Ma}$ to $297.8 \pm 8.1 \mathrm{Ma}$ (37 $\%$ of grains; Fig. 21B), $304.1 \pm 13.1$ Ma to $364.2 \pm 7.4$ Ma (12.5\% of grains; Fig. $21 \mathrm{C})$ and $381.8 \pm 7.5$ to $749.5 \pm 18.6$ ( $45 \%$ of grains; Fig. $21 \mathrm{C}$ ). The six oldest grains in the sample do not form a distinct age population and range from 880 to $1250 \mathrm{Ma}$ (5\% of grains; Fig. 21C).

Figure 22 represents the comparison between the probability density and KDE curves. The curves differ in Figure 22 such that the KDE curve is a smoother overall curve due to the bandwidth used in the calculation of the KDE curve. The two curves appear to be more similar in low grain density portions of the curve.

The youngest grains in this sample were analyzed at both UC-SC and ALC lab facilities. The youngest single-grain age for sample 12ZA13 (YSG) maximum depositional age is $245.4 \pm$ 
6.5 Ma. The youngest graphical (probability density plot) age peak controlled by more than one grain age (YPP) appears to be $247 \mathrm{Ma}(\mathrm{n}=43)$ for probability density function, and $269 \mathrm{Ma}$ $(n=37)$ for the KDE function. The mean age of the youngest two or more grains that overlap in age at $1 \sigma(\mathrm{YCl} \sigma)$ is $245.6 \pm 8.5 \mathrm{Ma}$ based on the six youngest grains. The mean age of the youngest three or more grains that overlap in age at $2 \sigma(\mathrm{YC} 2 \sigma)$ is $249 \pm 3.8$ Ma based on the four youngest grains. Lastly, the youngest detrital zircon age (YDZ) is $245+5.4-6.8 \mathrm{Ma}$ for this sample.

Maximum depositional ages ranged from $245 \pm 6.5$ to $249 \pm 3.8 \mathrm{Ma}$ (Table 3). The maximum depositional age of $249 \pm 3.8$ Ma was determined by using the YC2 $\sigma$ method (Fig. 21). The $\mathrm{YC} 2 \sigma$ method was used because it is the most statistically robust and conservative method for determining the maximum depositional age. 

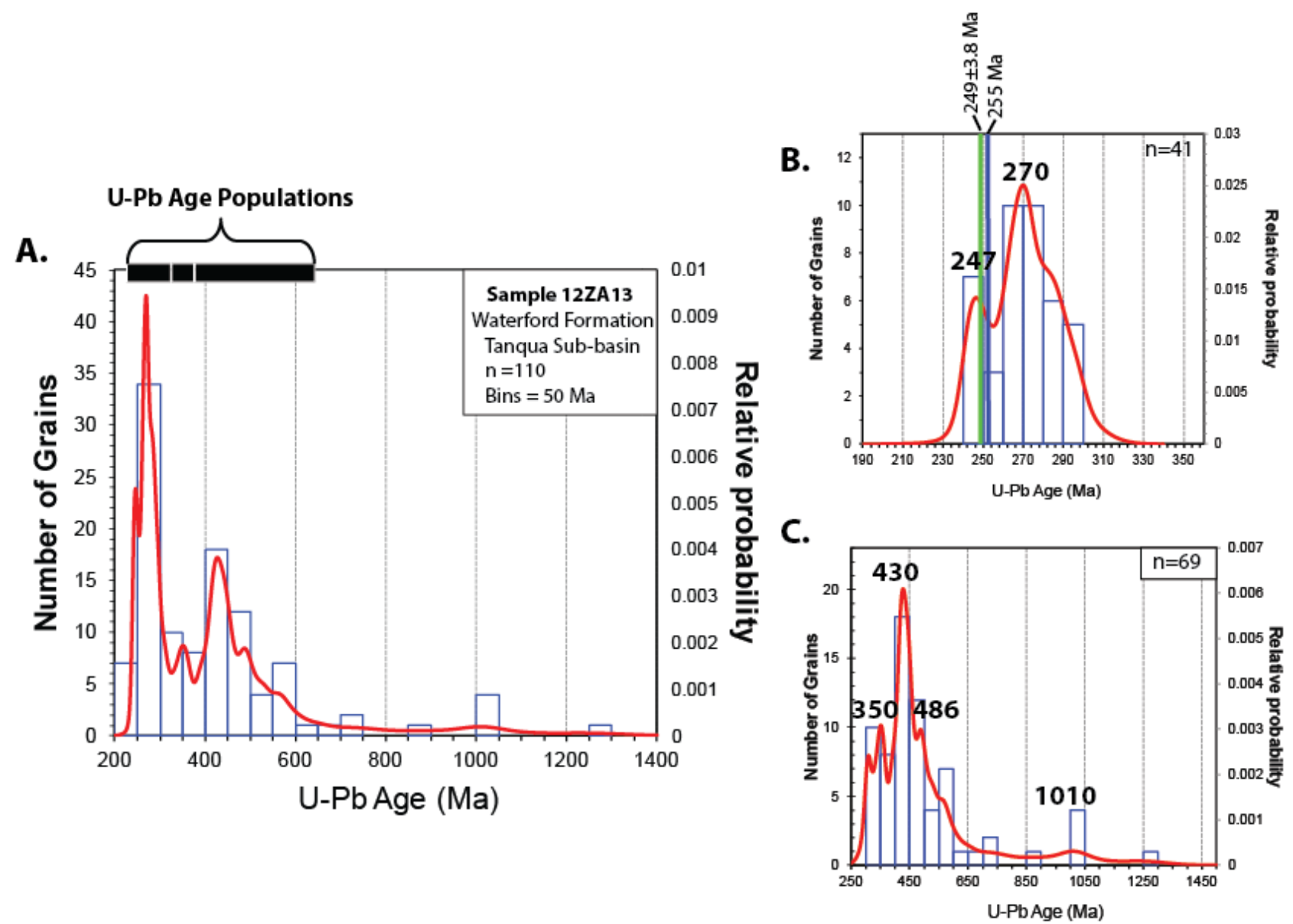

Figure 21: A) Relative probability-density curve (red) and 50 Ma histogram bins for sample 12ZA13. B) 240-300 Ma age population (10 Ma bins). The green line represents the maximum depositional age $(249 \pm 3.8 \mathrm{Ma})$ derived from this study and the blue line represents the depositional age (255 Ma) from Rubidge (1999). C) 300-1250 Ma age populations (50 Ma bins). 
Number of Grains

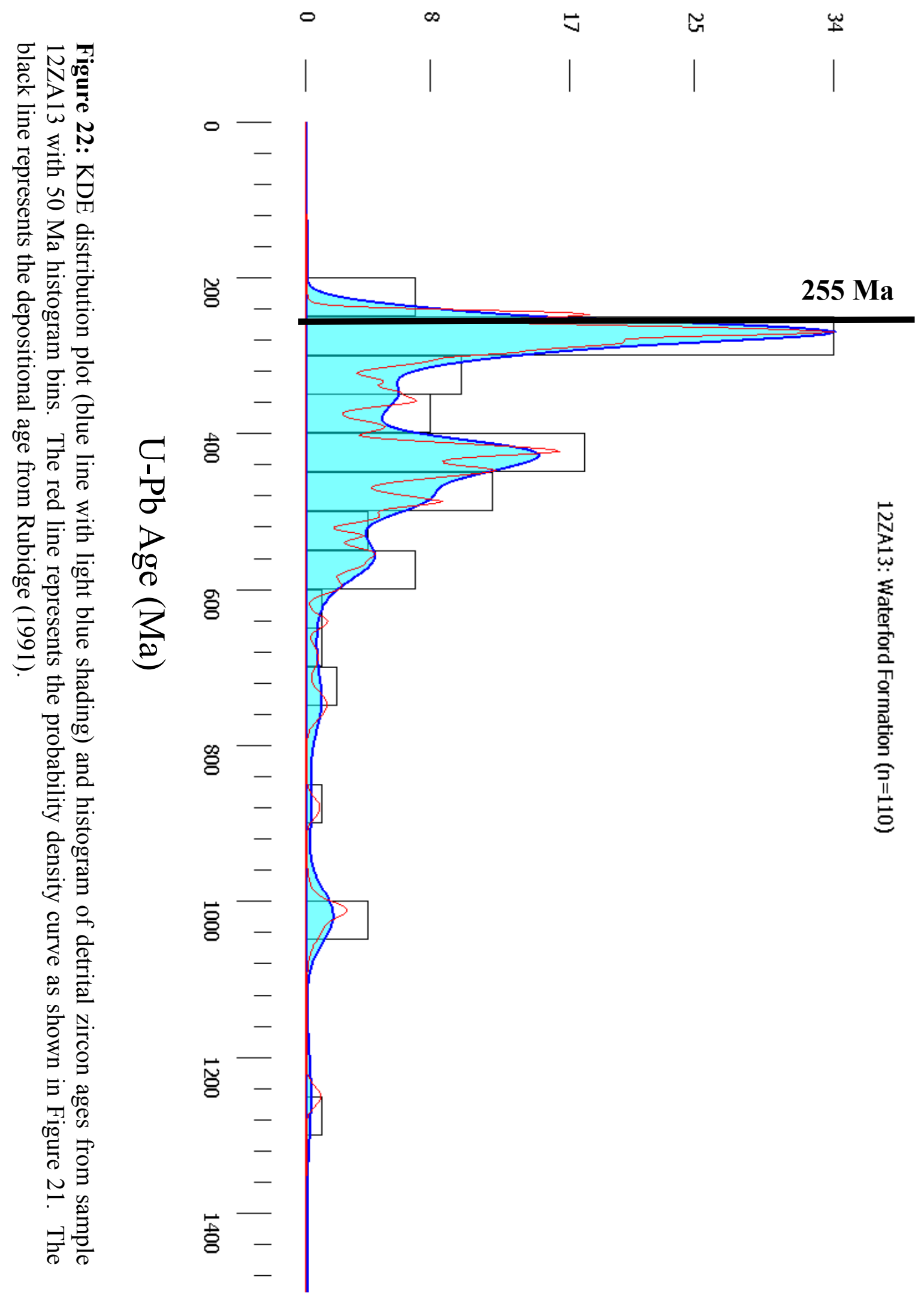




\subsubsection{Sample 12ZA26: Laingsburg Formation}

Sample 12ZA26 was taken from

the Middle Permian (Roadian)

Laingsburg Formation of the middle

Ecca Group in the Laingsburg subbasin (Fig. $16 \&$ 17). The depositional age of the Laingsburg Formation was determined by a reptilian fossil assemblage overlying the lower Beaufort Group (Rubidge, 1991) and radiometric ages from airfall ash zircon (Turner, 1999) that range from $255 \mathrm{Ma}$ to $270 \pm 1$ Ma. Fildani et al. (2007; 2009) reports absolute ages determined from zircon grains in airfall ashes in the lower Laingsburg Formation of $270.1 \pm 2$ Ma. The Laingsburg Formation is interpreted as turbidite

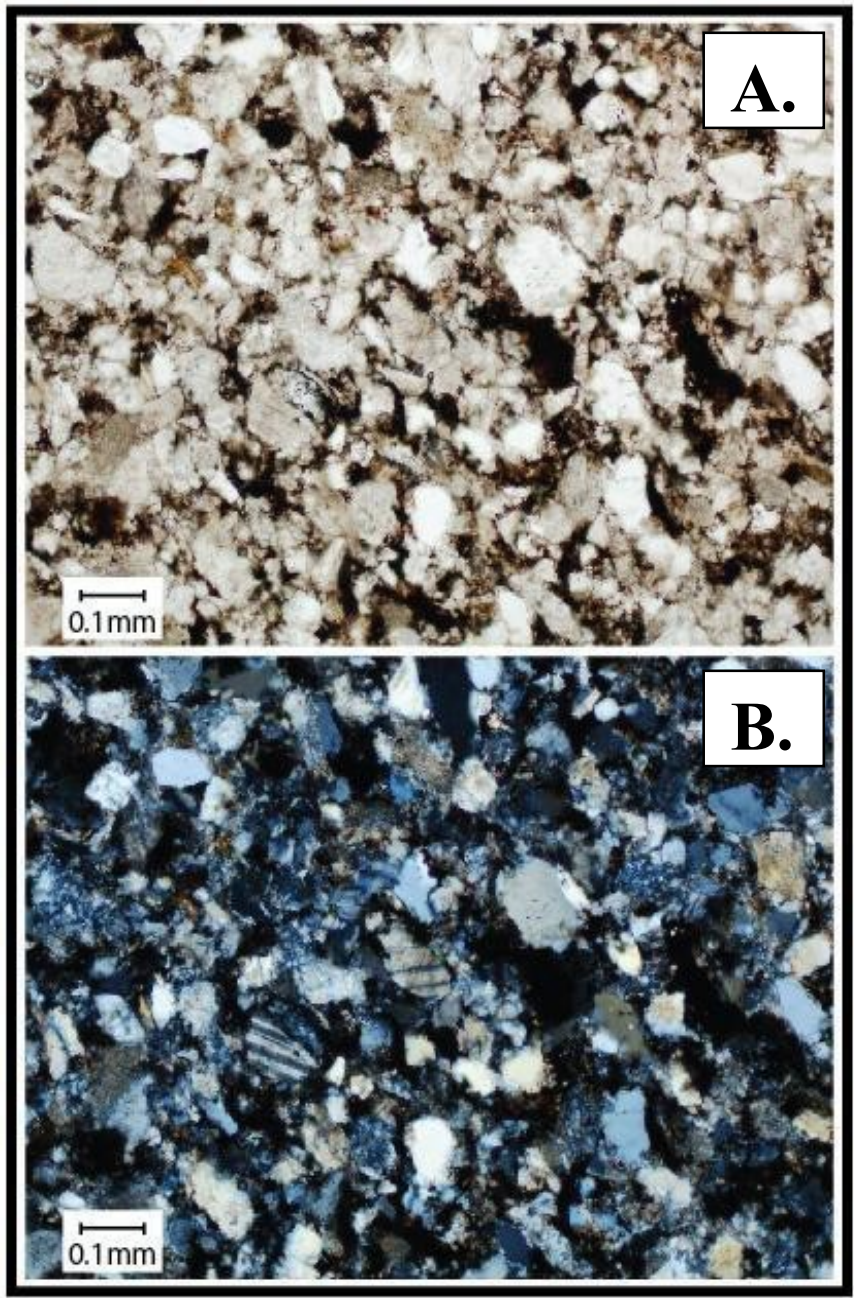

Figure 23: Thin-section image of sample 12ZA26 in plain and cross-polarized light which consists of moderately sorted, angular to subangular, fine- to medium-grained sandstone.

deposits within the lower Ecca Group [Bouma \& Wickens, 1994]. The turbidite sandstones exhibit an erosive base which incised underlying rock layers and had a relatively massive texture with some prominent graded bedding. The outcrop consisted mainly of medium- to thick-bedded sandstone interbedded with thin siltstone and mudstone beds. Sandstone beds contained a massive texture with normally graded beds. Overall the outcrop was relatively unaltered with 
slightly weathered surfaces appearing orange/brown and unweathered surfaces appearing light tan. The sample consisted of moderately sorted, angular to sub-rounded, medium- to fine-grained sand. No distinct bedding or laminae were observed in the hand sample or thin-section (Fig. 23). The lower fan of a deepwater fan depositional setting is interpreted due to the presence of the erosive base and graded beds present in the outcrop caused by the failure of continental slope sediment creating high flow energies followed by an abrupt decrease in flow energy. Sandstone composition consisted of moderate quartz and abundant lithics and feldspar. Sample 12ZA26 yielded abundant zircon (thousands). Zircon grains were prismatic, transparent/colorless to slightly yellow, and ranged in size from 10-55 $\mu \mathrm{m}$.

A total of 174 grains were analyzed from sample 12ZA26, with 100 grains analyzed at the UC-Santa Cruz lab facility and 74 grains analyzed at the ALC lab facilities. Analysis of sample 12ZA26 yielded 91 reliable ages. A total of 83 grains were rejected, with 66 grains rejected due to discordance, nine grains rejected due to high ${ }^{204} \mathrm{~Pb}$, four grains rejected due to low ${ }^{206} \mathrm{~Pb} /{ }^{204} \mathrm{~Pb}$ isotope ratio, three grains rejected due to high ${ }^{206} \mathrm{~Pb} /{ }^{238} \mathrm{U}$ error, and one grain rejected due to reverse discordance. Ages within this sample range from $234.6 \pm 2$ Ma to $1963 \pm$ $19 \mathrm{Ma}$ (Fig. 24A). In general, all ages fall within two distinct age populations which range between $234.6 \pm 2$ Ma to $316.1 \pm 3.9 \mathrm{Ma}$ (56 \% of grains; Fig. 24B), and $376.2 \pm 7.5$ Ma to 742 Ma (37\% of grains; Fig. 24C). The six oldest grains in the sample do not form a distinct age population and range from 906 to $1100 \mathrm{Ma}$ (7\% of grains; Fig. 21C).

Figure 25 represents the comparison between the probability density and KDE curves. The curves differ in Figure 25 such that the KDE curve is a smoother overall curve due to the bandwidth used in the calculation of the KDE curve. The two curves appear to be more similar in low grain density portions of the curve. 
The youngest grains in this sample were analyzed at both UC-SC and ALC lab facilities. The youngest single-grain age for sample 12ZA26 (YSG) maximum depositional age is $252 \pm$ 19.6 Ma. The youngest graphicalage peak displayed by the probability density plot that was controlled by more than one grain age (YPP) appears to be $255 \mathrm{Ma}(\mathrm{n}=41)$ for probability density function, and $272 \mathrm{Ma}(\mathrm{n}=36)$ for the KDE function. The mean age of the youngest two or more grains that overlap in age at $1 \sigma(\mathrm{YC} 1 \sigma)$ is $259 \pm 19 \mathrm{Ma}$ based on the two youngest grains. The mean age of the youngest three or more grains that overlap in age at $2 \sigma(\mathrm{YC} 2 \sigma)$ is $265 \pm 4.4 \mathrm{Ma}$ based on the four youngest grains. Lastly, the youngest detrital zircon age (YDZ) is $254+9.6-24$ Ma for this sample.

Maximum depositional ages ranged from $252 \pm 19.6$ Ma to $265 \pm 4.4$ Ma. The maximum depositional age of $265 \pm 4.4$ was determined by using the YC2 $\sigma$ method (Fig. 21). The YC2 $\sigma$ method was used because it is the most statistically robust and conservative method for determining the maximum depositional age. 

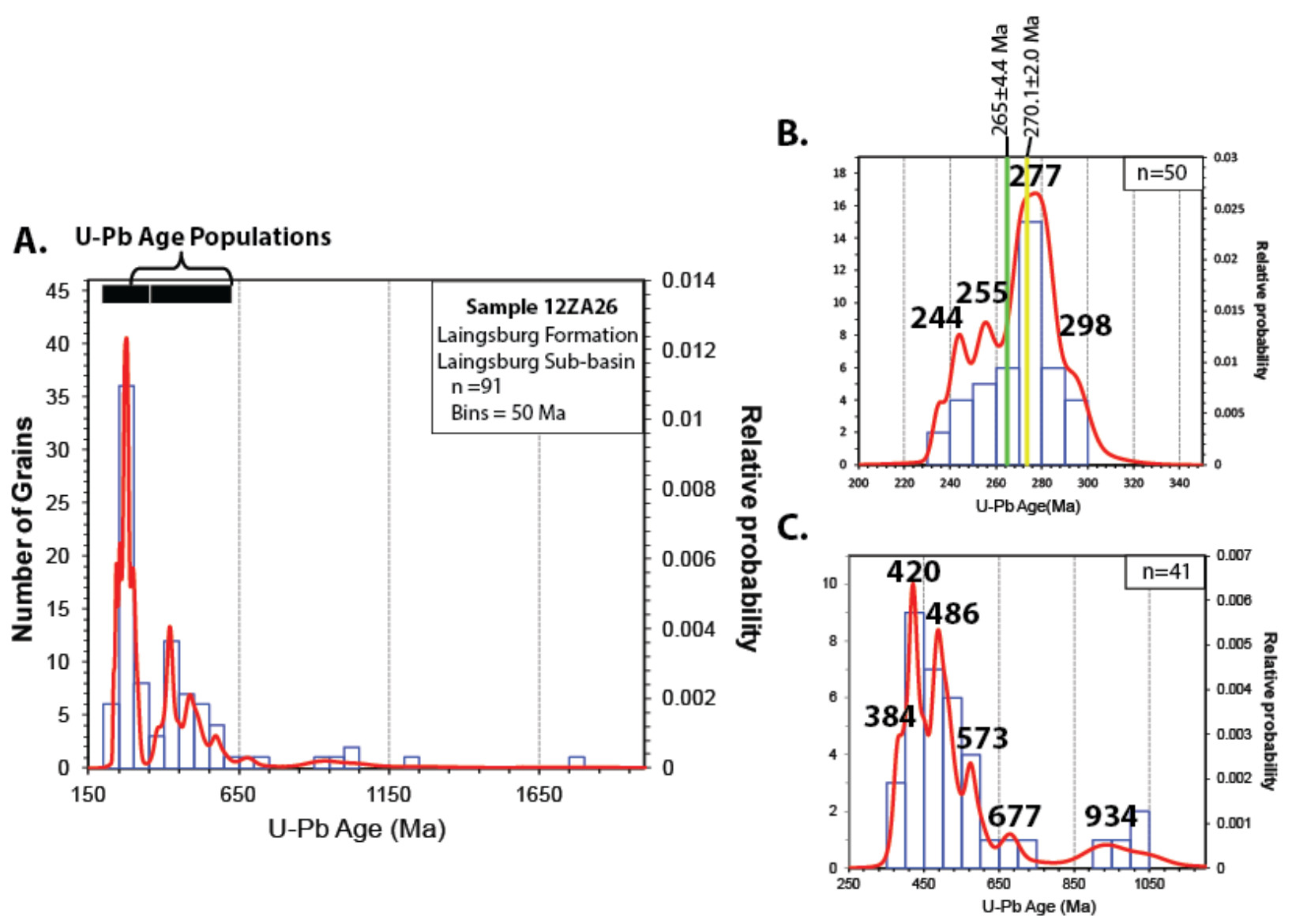

Figure 24: A) Relative probability-density curve (red) and $50 \mathrm{Ma}$ histogram bins (blue) for sample 12ZA26. B) 230-316 Ma age population (10 Ma bins). The green line represents the maximum depositional age $(265 \pm 4.4 \mathrm{Ma})$ derived from this study. The yellow line represents an age of airfall ash zircon $(270.1 \pm 2 \mathrm{Ma})$ collected from an ash within the same formation from Fildani et al. (2008 \& 2009). C) 375-1050 Ma age populations (50 Ma bins). 


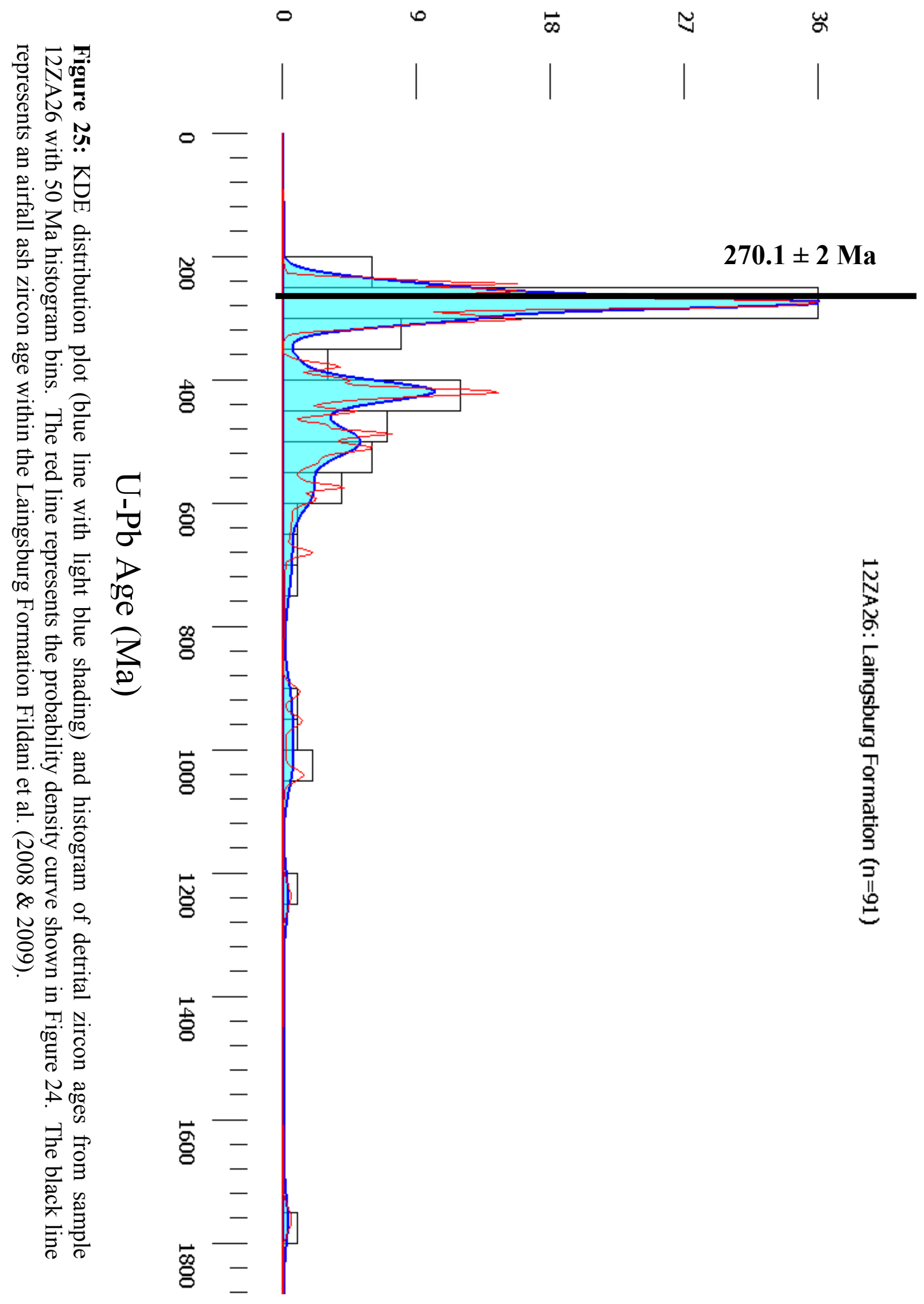




\subsubsection{Sample 09-BL-C1: Laingsburg Formation}

Sample 09-BL-C1 was taken from the Middle Permian (Roadian) Laingsburg Formation of the middle Ecca Group in the Laingsburg sub-basin (Fig. $16 \&$ 17). The depositional age of the Laingsburg Formation was determined by a reptilian fossil assemblage overlying the lower Beaufort Group (Rubidge, 1991) and radiometric ages from airfall ash zircon (Turner, 1999) and ranges from $255 \mathrm{Ma}$ to $270 \pm 1$ Ma. Fildani et al. (2007; 2009) reports absolute ages determined from zircon grains in airfall ashes in the middle Laingsburg Formation of $248.9 \pm 2.6$ Ma. The Laingsburg

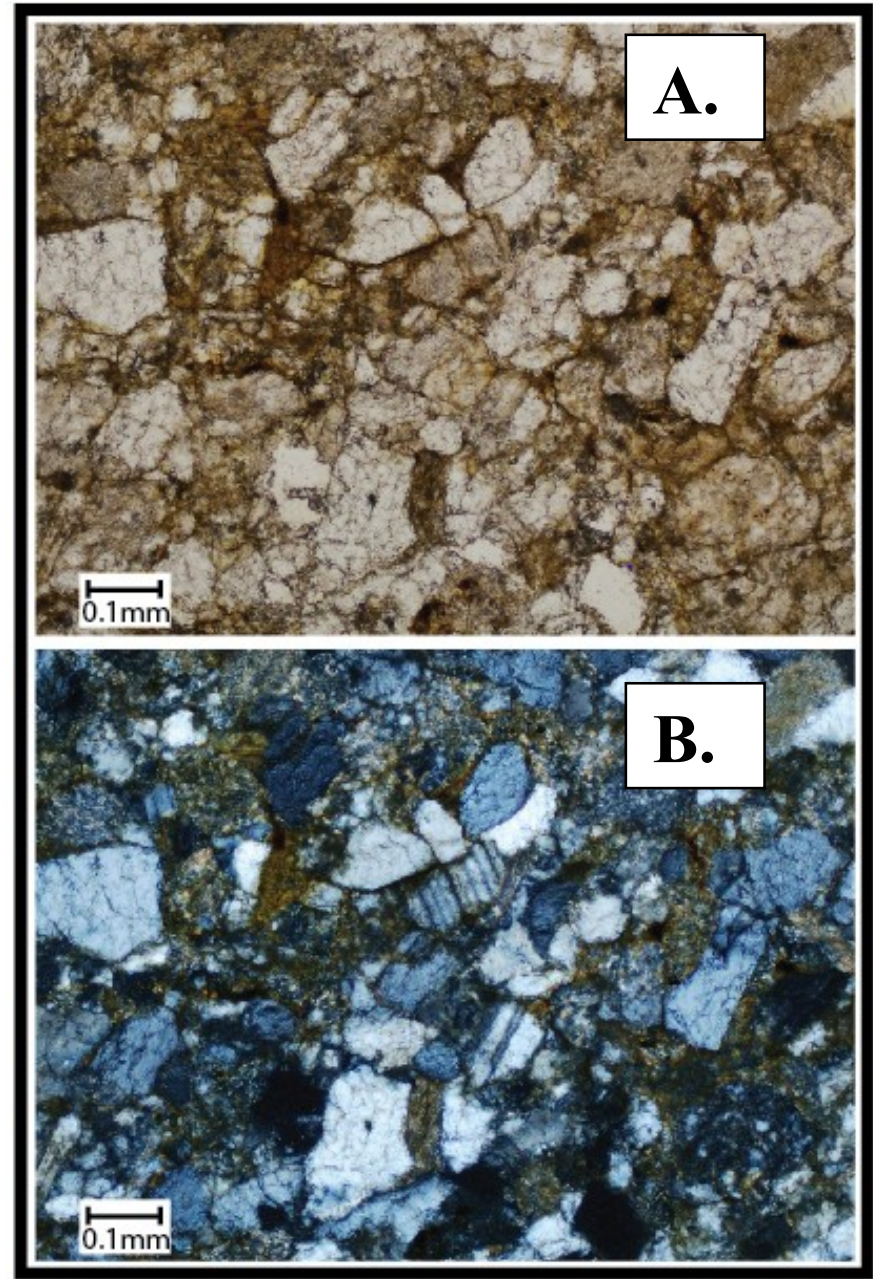

Figure 26: Thin-section image of sample 09-BL$\mathrm{C} 1$ in plain light (A) and cross-polarized light (B). The sample consists of moderately sorted, angular to sub-angular, fine- to medium-grained sandstone.

Formation is interpreted as turbidite deposits within the lower Ecca Group [Bouma \& Wickens, 1994]. The turbidites exhibit erosive bases which incised into underlying rock layers and had a massive texture with some prominent normally graded bedding from medium- to fine-grained sandstone. The outcrop consisted mainly of medium- to thick-bedded sandstone interbedded with thin siltstones and mudstone beds. Overall the outcrop was relatively unaltered with slightly weathered surfaces appearing orange/brown and unweathered surfaces appearing light tan. The 
sample consisted of moderately sorted, angular to sub-rounded, medium- to fine-grained sand. No distinct bedding or laminae were observed in the hand sample or thin-section (Fig. 26). The lower fan of a deepwater fan depositional setting is interpreted due to the presence of the erosive base and graded beds present in the outcrop caused by the failure of continental slope sediment creating high flow energies followed by an abrupt decrease in flow energy. Sandstone composition consisted of moderate quartz and abundant lithics and feldspar. Sample 09-BL-C1 yielded abundant zircon (thousands). Zircon grains were prismatic, transparent/colorless to slightly yellow, and ranged in size from 10-55 $\mu \mathrm{m}$.

A total of 101 zircon grains were analyzed from sample 09-BL-C1 at ALC lab facilities. Analysis of sample 09-BL-C1 yielded 82 reliable ages. A total 19 grains were rejected, with seven grains rejected due to high ${ }^{204} \mathrm{~Pb}$ concentration; six grains rejected due to discordance, four grains rejected due to reverse discordance, and two grains rejected due to high ${ }^{206} \mathrm{~Pb} /{ }^{238} \mathrm{U}$ error. Ages within this sample range from $265 \pm 11.8$ Ma to $2740.6 \pm 9.6 \mathrm{Ma}$ (Fig. 27A). In general, all ages fall within three distinct age populations which range between $265 \pm 11.8 \mathrm{Ma}$ to $306.5 \pm 6.2$ Ma (25\% of grains; Fig. 27B), $359 \pm 8.8$ Ma to $767.8 \pm 11.1$ Ma (60\% of grains; Fig. $27 \mathrm{C})$, and $947.7 \pm 55.8 \mathrm{Ma}$ to $1138.1 \pm 38.4 \mathrm{Ma}(12 \%$ of grains; Fig. $27 \mathrm{C})$. The three oldest grains in the sample do not form a distinct age population and range from 1679 to $2800 \mathrm{Ma}$ ( $3 \%$ of grains; Fig. 27A).

Figure 28 represents the comparison between the probability density and KDE curves. The curves differ in Figure 28 such that the KDE curve is a smoother overall curve due to the bandwidth used in the calculation of the KDE curve. The two curves appear to be more similar in low grain density portions of the curve.

All grains in this sample were analyzed at the ALC lab facilities. The youngest single- 
grain age for sample 09-BL-C1 (YSG) maximum depositional age is $265 \pm 12 \mathrm{Ma}$. The youngest graphical (probability density plot) age peak controlled by more than one grain age (YPP) appears to be $278 \mathrm{Ma}(\mathrm{n}=22)$ for probability density function, and $275 \mathrm{Ma}(\mathrm{n}=36)$ for the $\mathrm{KDE}$ function. The mean age of the youngest two or more grains that overlap in age at $1 \sigma(\mathrm{YC} 1 \sigma)$ is $271 \pm 10 \mathrm{Ma}$ based on the three youngest grains. The mean age of the youngest three or more grains that overlap in age at $2 \sigma(\mathrm{YC} 2 \sigma)$ is $270 \pm 5$ Ma based on the three youngest grains. Lastly, the youngest detrital zircon age (YDZ) is $266+5.8-14$ Ma for this sample.

Maximum depositional ages ranged from $265 \pm 12$ to $270 \pm 5$ Ma. The maximum depositional age of $270 \pm 5 \mathrm{Ma}$ was determined by using the YC2 $\sigma$ method (Fig. 27). The YC2 $\sigma$ method was used because it is the most statistically robust and conservative method for determining the maximum depositional age. 

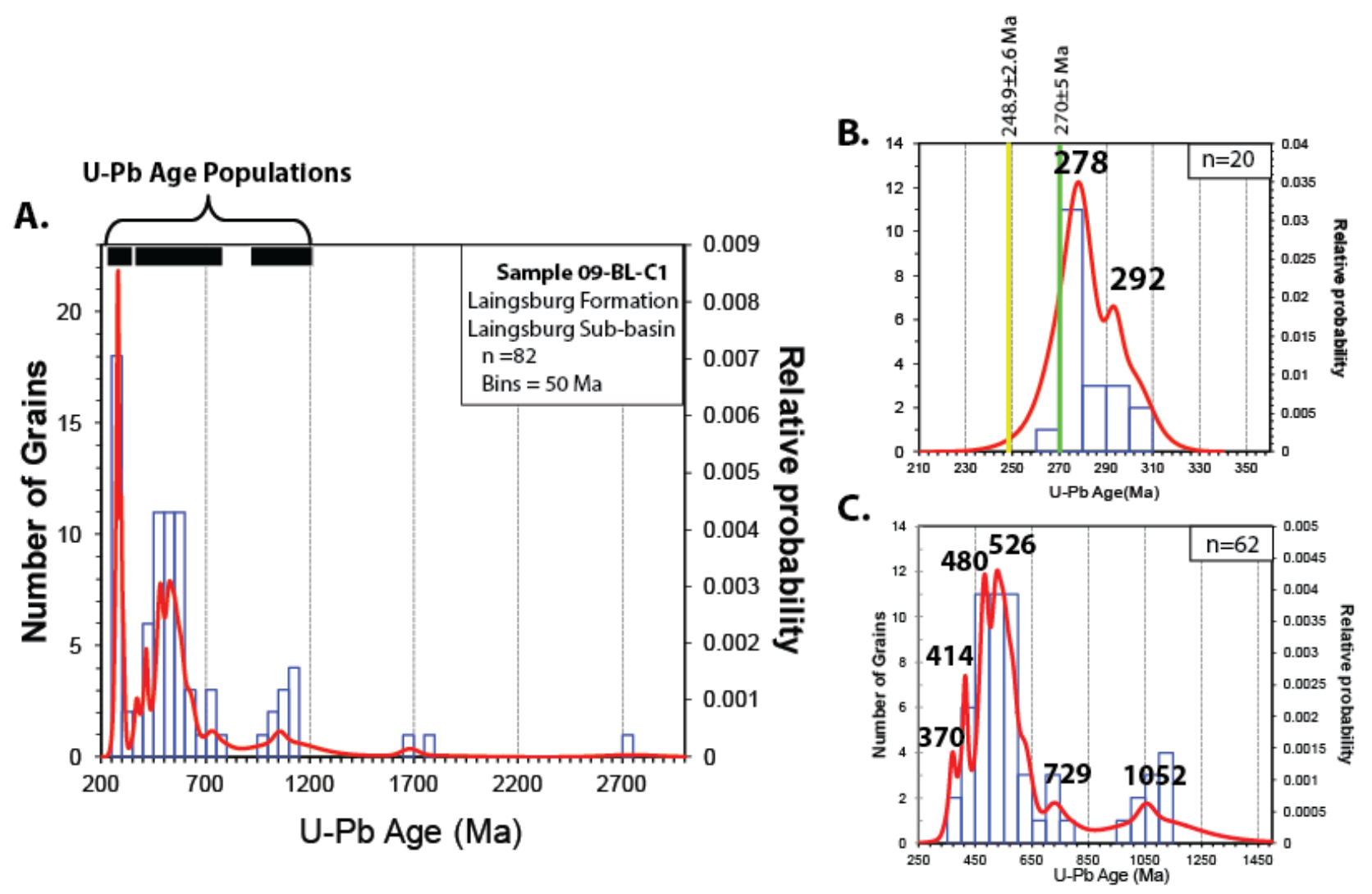

Figure 27: A) Relative probability-density curve (red) and 50 Ma histogram bins (blue) for sample 09-BL-C1. B) 265-307 Ma age population (10 Ma bins). The green line represents the maximum depositional age derived from this study. The yellow line represents an age of airfall ash zircon collected from an ash within the same formation from Fildani et al. (2009). C) 350-1140 Ma age populations (50 Ma bins). 
Number of Grains

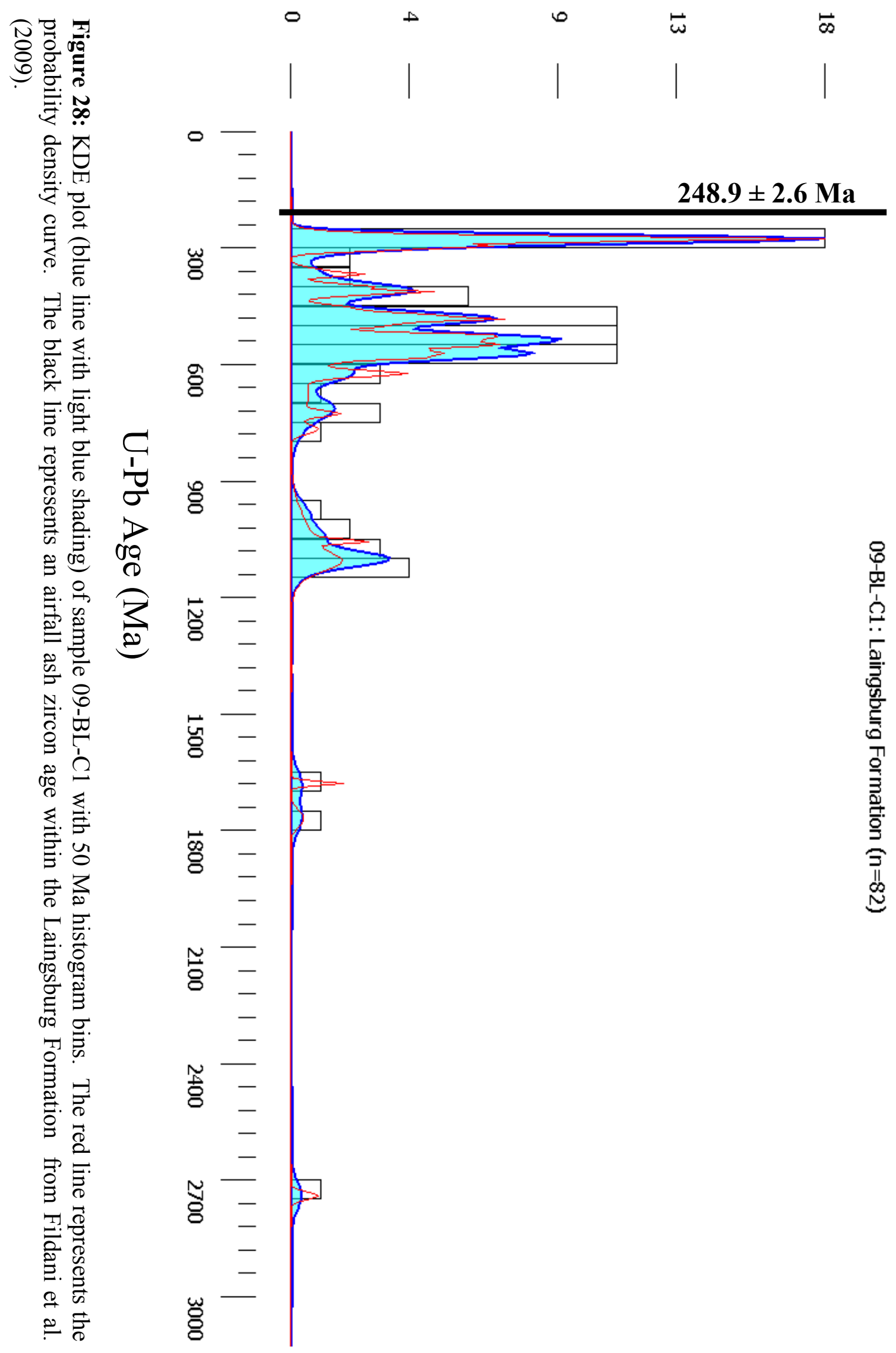




\subsubsection{Sample 13ZA91: Waterford Formation}

Sample 13ZA91 was taken from the Late Permian (Capitanian) Waterford Formation of the upper Ecca Group in the Laingsburg sub-basin (Fig. $16 \&$ 17). The depositional age (255 Ma) determined by Rubidge (1991) is based on a reptilian fossil assemblage found in the lower Beaufort Group. The Waterford Formation is interpreted as deltaic deposits within the uppermost Ecca Group [Johnson et al., 1996]. The outcrop consisted of medium- to thick-bedded sandstones interbedded with siltstones and mudstones. Tangential cross-beds, horizontal laminae and oscillatory ripple laminations were prominent throughout the outcrop. Overall the outcrop was relatively unaltered with slight weathered surfaces appearing black/brown and unweathered

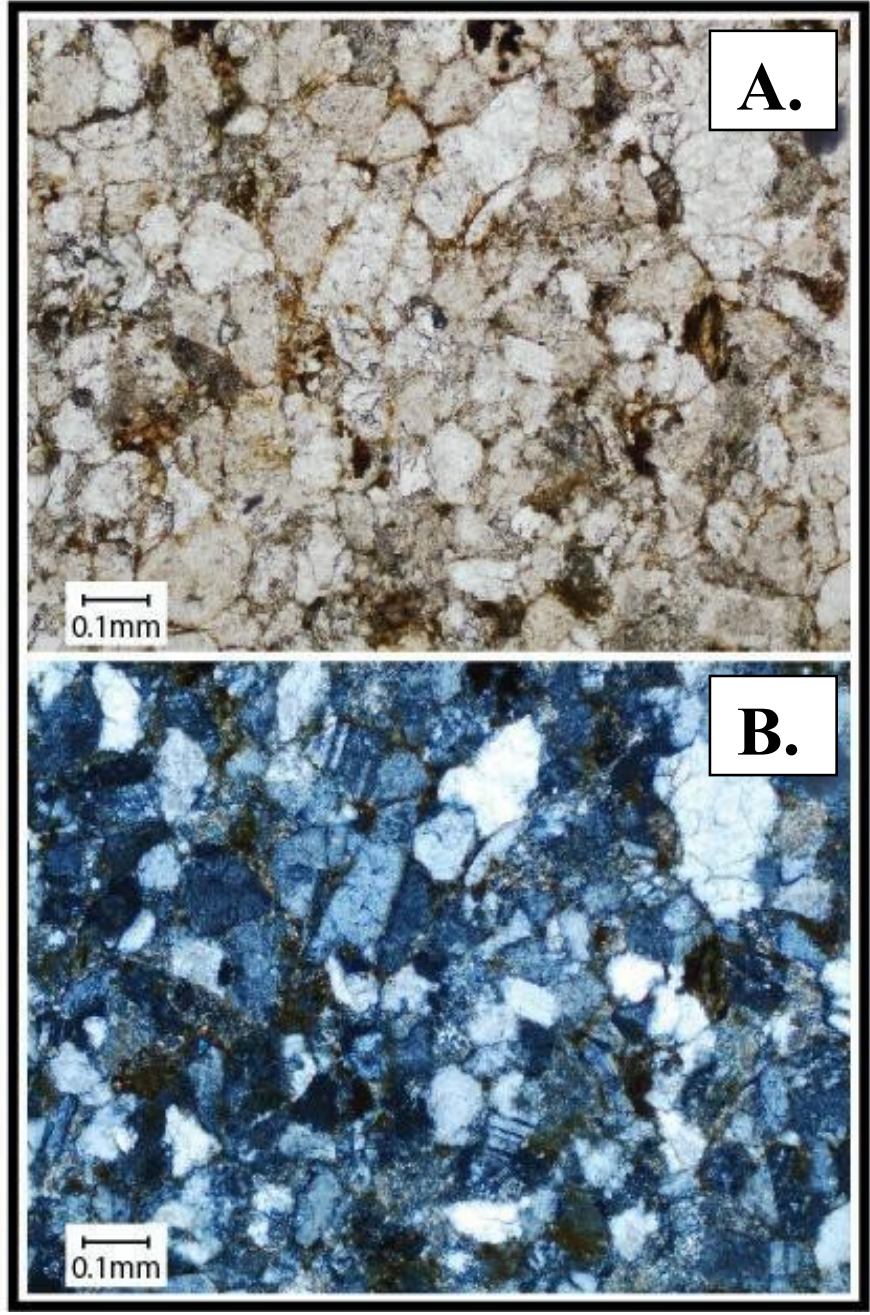

Figure 29: Thin-section image of sample 13ZA91 in plain light (A) and cross-polarized light (B). This sample consists of moderately to well-sorted, angular to sub-angular, fine- to medium-grained sandstone.

surfaces appearing light tan (Fig.

30). The sample consisted of

moderate to well sorted, angular to sub- rounded, medium- to fine-grained sand. No distinct bedding or laminae were observed in the hand sample or thin-section (Fig. 29). The depositional 
environment of the sampled portion of the Waterford Formation was likely the delta front of a wave-dominated delta based on the interbedded nature of the outcrop, trace fossils present, and oscillatory flow patterns. Sandstone composition consisted of moderate quartz and abundant lithics and feldspar. Sample 13ZA91 yielded abundant zircon (several hundreds to thousands). Zircon grains were prismatic, transparent/colorless to slightly yellow, and ranged in size from $10-40 \mu \mathrm{m}$.

A total of 100 grains were analyzed from sample 13ZA91 at the ALC lab facilities. Analysis of sample 13ZA91 yielded 89 reliable ages. A total of 11 grains were rejected, with four grains rejected due to discordance, three grains rejected due to high ${ }^{204} \mathrm{~Pb}$ concentration, two grains rejected due to high ${ }^{206} \mathrm{~Pb} /{ }^{238} \mathrm{U}$ error, one grain rejected due to high ${ }^{206} \mathrm{~Pb} /{ }^{207} \mathrm{~Pb}$ error, and one grain rejected due to reverse discordance. Ages within this sample range from $267.7 \pm 5.1$ Ma to $1288.8 \pm 73.9$ Ma (Fig. 31A). In general, all ages fall within six distinct age populations which range between $267.7 \pm 5.1 \mathrm{Ma}$ to $317 \pm 6.9 \mathrm{Ma}$ (40\% of grains; Fig. $31 \mathrm{~B}), 383.6 \pm 10.5$ Ma to $442.1 \pm 23.6 \mathrm{Ma}(10 \%$ of grains; Fig. $30 \mathrm{C}), 463.7 \pm 10.9$ Ma to $516.8 \pm 18.4 \mathrm{Ma}(17 \%$ of grains; Fig. $31 \mathrm{C}), 540.2 \pm 7.2 \mathrm{Ma}$ to $590.8 \pm 10.2 \mathrm{Ma}$, (12\% of grains; Fig. $31 \mathrm{C}), 641.9 \pm 6.6$ Ma to $669.7 \pm 8.2 \mathrm{Ma}(7 \%$ of grains; Fig. $31 \mathrm{C})$, and $1025.3 \pm 56.4$ to $1098.9 \pm 33.7$ (8\% of grains; Fig. 31C). A total of six grains Neoproterozoic to Mesoproterozoic in age in the sample do not form a distinct age population and ranges from 1103 to 1288 Ma (7 \% of grains; Fig. 31C).

Figure 32 represents the comparison between the probability density and KDE curves. The curves differ in Figure 32 such that the KDE curve is a smoother overall curve due to the bandwidth used in the calculation of the KDE curve. The two curves appear to be more similar in low grain density portions of the curve. 
All grains in this sample were analyzed at the ALC lab facilities. The youngest singlegrain age for sample 13ZA91 (YSG) maximum depositional age is $267 \pm 5.1$ Ma. The youngest graphical (probability density plot) age peak controlled by more than one grain age (YPP) appears to be $274 \mathrm{Ma}(\mathrm{n}=25)$ for probability density function, and $274 \mathrm{Ma}(\mathrm{n}=29)$ for the KDE function. The mean age of the youngest two or more grains that overlap in age at $1 \sigma(\mathrm{YC} 1 \sigma)$ is $270 \pm 3.4$ Ma based on the nine youngest grains. The mean age of the youngest three or more grains that overlap in age at $2 \sigma(\mathrm{YC} 2 \sigma)$ is $269 \pm 2 \mathrm{Ma}$ based on the four youngest grains. Lastly, the youngest detrital zircon age (YDZ) is $266,+2.7-5.2 \mathrm{Ma}$ for this sample.

Maximum depositional ages ranged from $267 \pm 5.1$ to 274 Ma. The maximum depositional age of $269 \pm 2$ Ma was determined by using the YC2 $\sigma$ method (Fig. 32). The YC2 $\sigma$ method was used because it is the most statistically robust and conservative method for determining the maximum depositional age. 


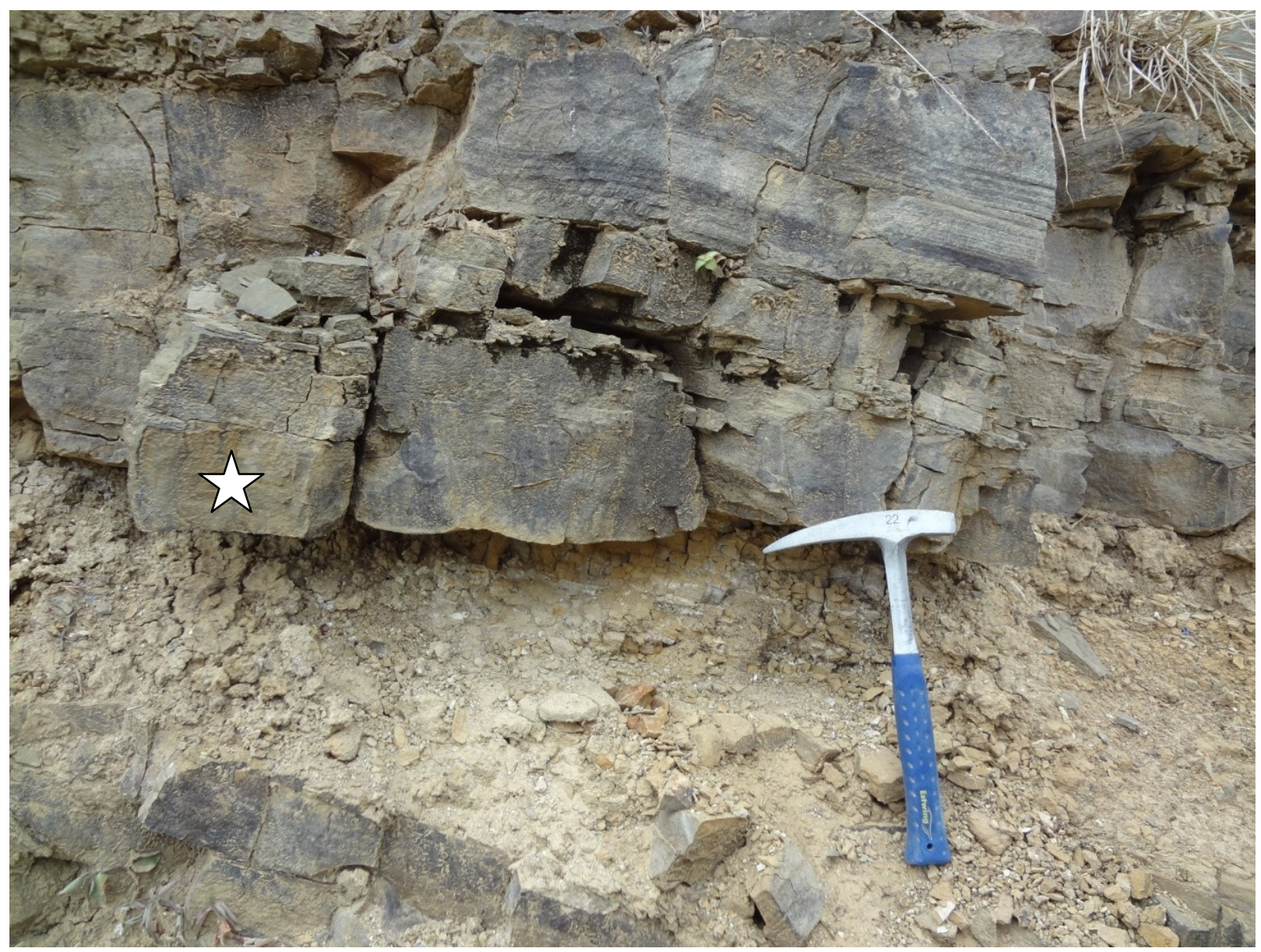

Figure 30: Outcrop photograph of the location of sample 13ZA91. The white star indicates where the sample was taken. The sample overlies an airfall ash bed. Note the dark horizontal laminations at the top of the photo. 

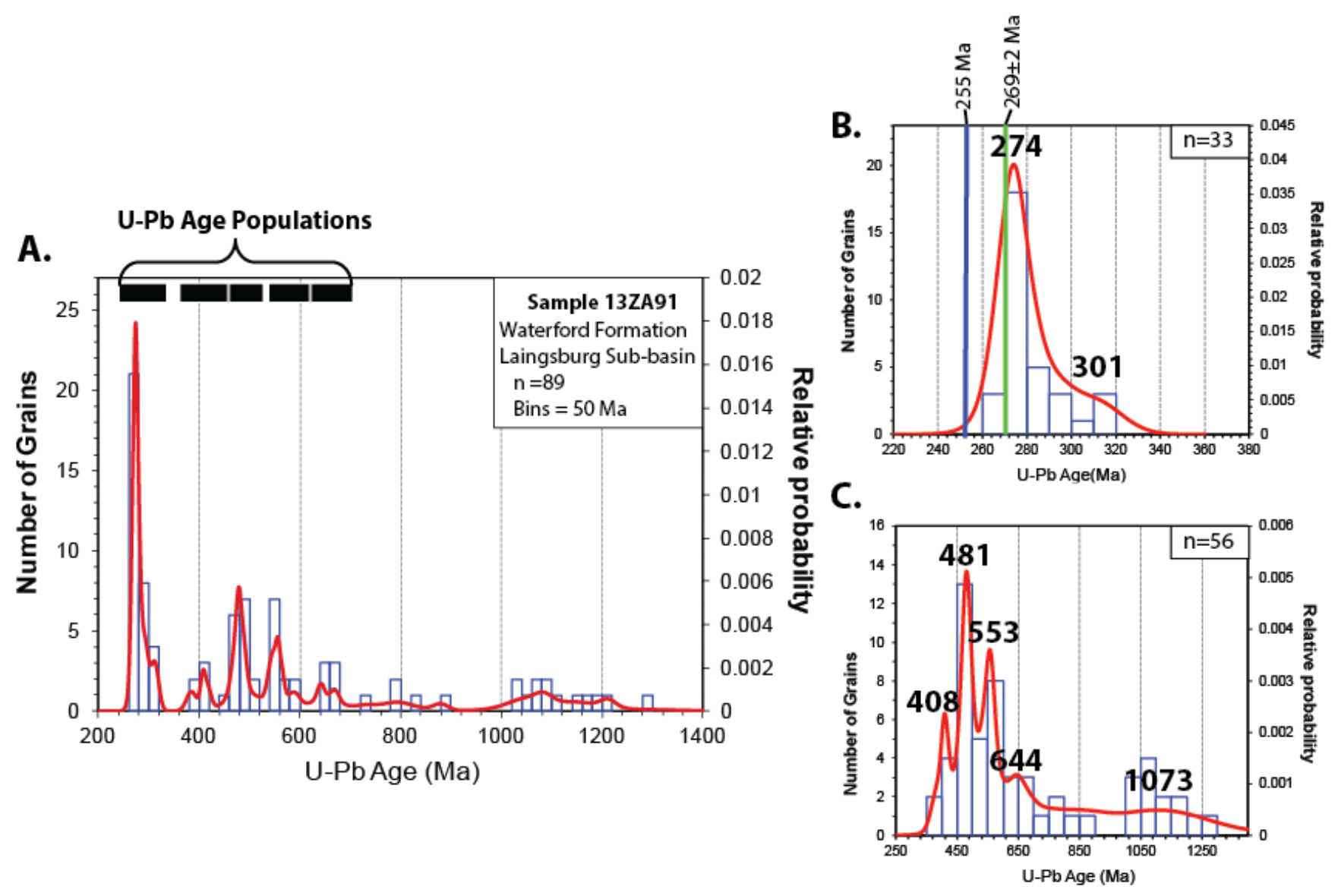

Figure 31: A) Relative probability-density curve (red) and $50 \mathrm{Ma}$ histogram bins (blue) for sample 13ZA91. B) 267-317 Ma age population (10 Ma bins). The green line represents the maximum depositional age $(269 \pm 2 \mathrm{Ma})$ derived from this study and the blue line represents the depositional age (255 Ma) from Rubidge (1991). C) 383-1290 Ma age populations (50 Ma bins). 
Number of Grains

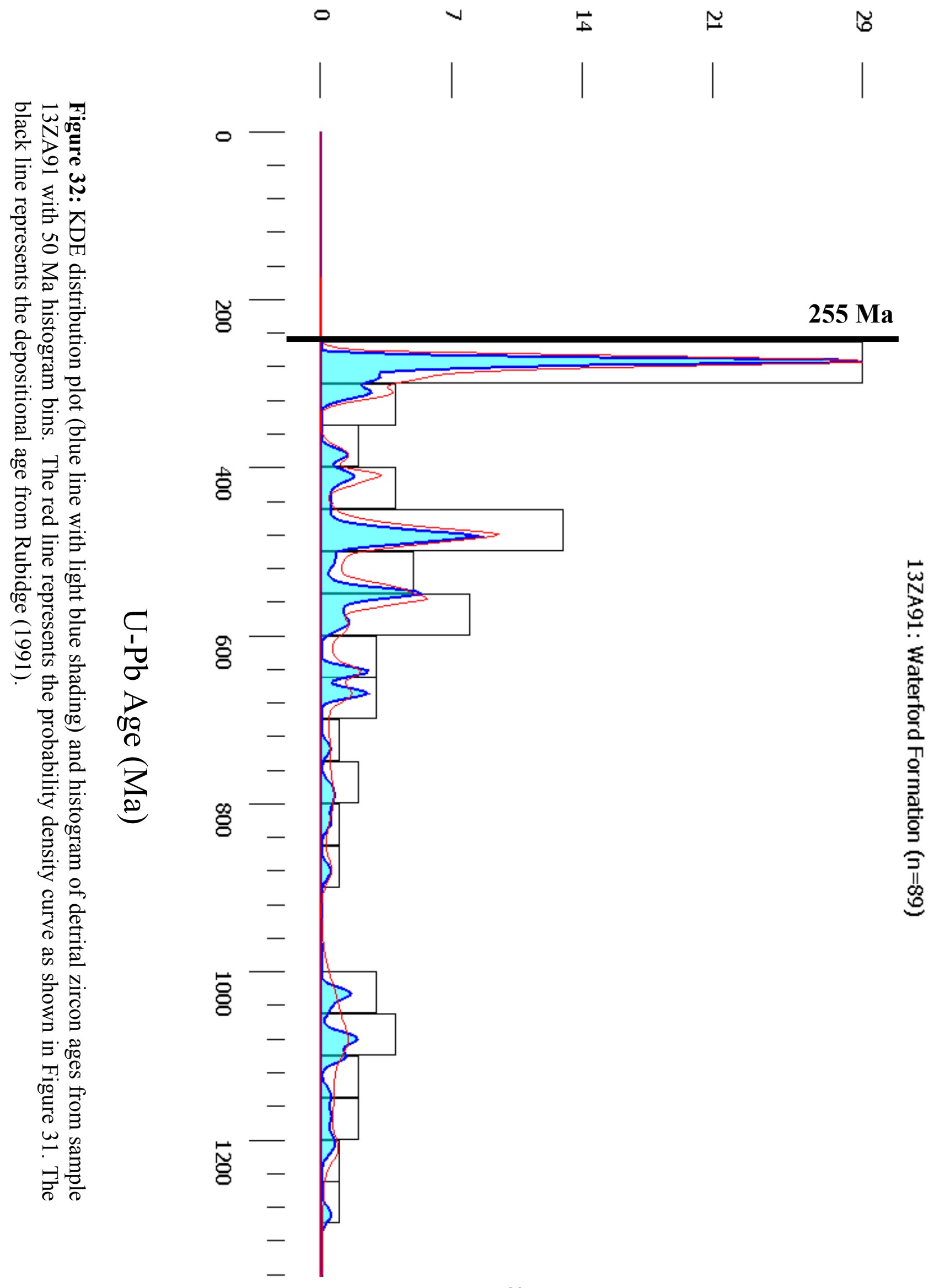




\subsubsection{Sample 13ZA93: Beaufort Group}

Sample 13ZA93 was taken
from the Late Permian to Early
Triassic (Wuchiapingian) lower
Beaufort Group in the Laingsburg
sub-basin (Fig. $16 \quad \&$ 17). The
Depositional age of $260.4 \mathrm{Ma}$ in the
lower Beaufort group was determined

by Retallack et al. (2006) by using paleobotanical, paleopedological, and carbon isotopic methods. Another depositional age of $255 \mathrm{Ma}$ determined by Rubidge (1991) was determined by using biostratigraphy and is based on a reptilian fossils assemblage found in the lower Beaufort Group. The lower Beaufort Group is interpreted as fluvial deposits within the lower Beaufort

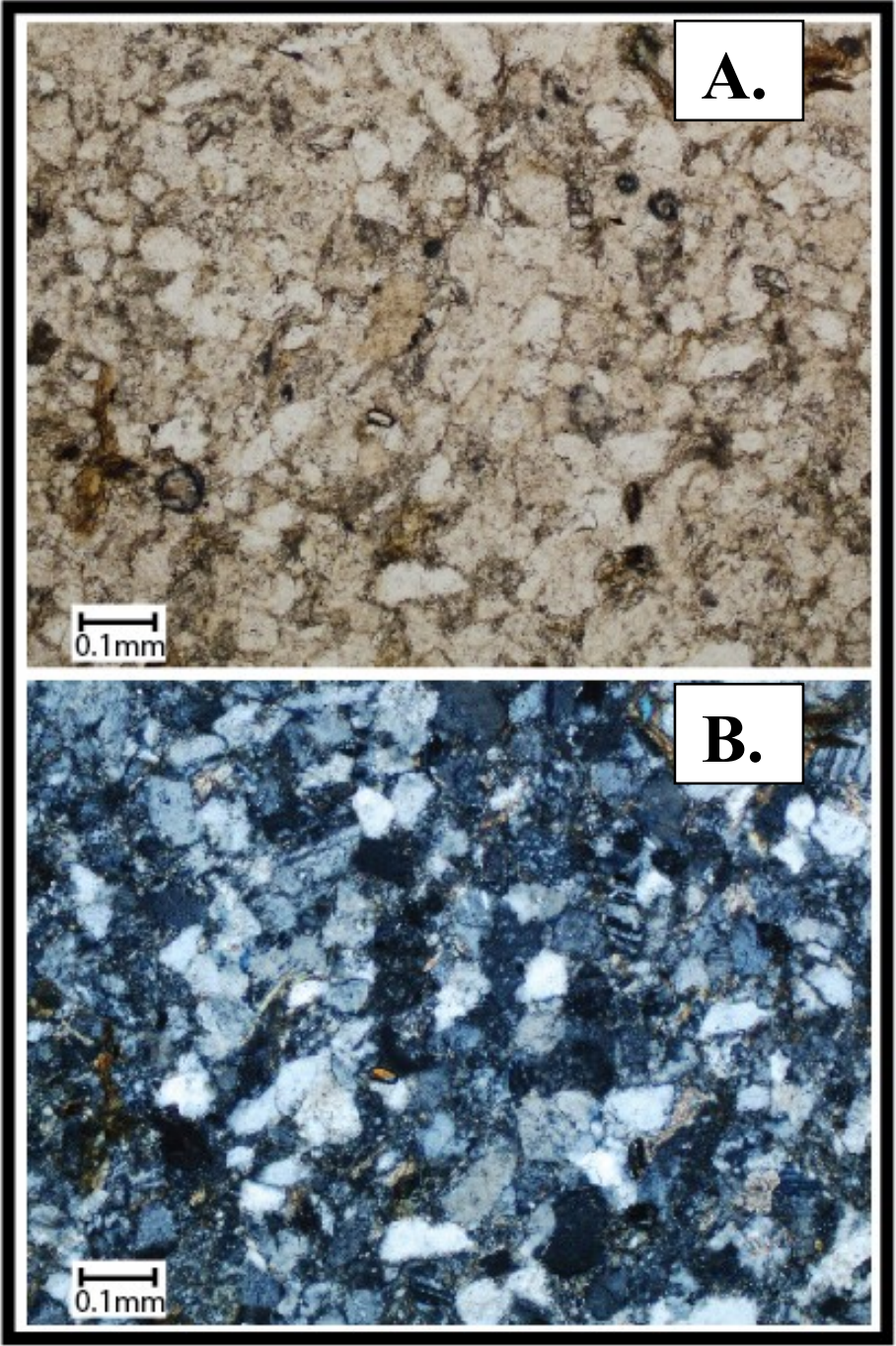

Figure 33: Thin-section image of sample 13ZA93 in plain light (A) and cross-polarized light (B). This sample consists of moderately to well-sorted, angular to sub-angular, fine- to medium-grained sandstone.

Group [Johnson et al., 1996]. The sampled outcrop consisted of thin- to thick-bedded sandstone interbedded with thin- to medium-bedded mudstone. The sandstones in the outcrop contained a massive texture with areas of slight horizontal laminations. Overall the outcrop was relatively unaltered with moderately weathered surfaces appearing maroon and unweathered surfaces 
appearing light tan to orange (Fig. 34). The sample consisted of moderate to well sorted, angular to sub-rounded, medium- to fine-grained sand. No distinct bedding or laminae were observed in the hand sample or thin-section (Fig. 33). A meandering fluvial depositional setting is interpreted due to the absence of marine fossils, heavily oxidized (maroon) sandstone layers, and unidirectional flow patterns. The airfall ash underlying the sampled interval was likely from overbank floodplain deposits (Fig. 35). Sandstone composition consisted of moderate quartz and abundant lithics and feldspar. Sample 13ZA93 yielded abundant zircon (hundreds). Zircon grains were prismatic, transparent/colorless, and ranged in size from 10-25 $\mu \mathrm{m}$.

A total of 100 grains were analyzed from sample 13ZA93 at the ALC lab facilities. Analysis of sample 13ZA93 yielded 87 reliable ages. A total of 13 grains were rejected, with five grains rejected due to high ${ }^{204} \mathrm{~Pb}$ concentration, four grains rejected due to discordance, two grains rejected due to low ${ }^{206} \mathrm{~Pb} /{ }^{204} \mathrm{~Pb}$ isotope ratio, one grain rejected due to high ${ }^{206} \mathrm{~Pb} /{ }^{238} \mathrm{U}$ error, and one grain rejected due to reverse discordance. Ages within this sample range from $259.2 \pm 7.4$ Ma to $2709.2 \pm 9.3 \mathrm{Ma}$ (Fig. 35A). In general, all ages fall within five distinct age populations which range between $259.2 \pm 7.4$ Ma to $296.6 \pm 3.1 \mathrm{Ma}$ (22\% of grains; Fig. 35B), $446.2 \pm 4.2 \mathrm{Ma}$ to $489.8 \pm 12.8 \mathrm{Ma}(20 \%$ of grains; Fig. $35 \mathrm{C}), 524.8 \pm 12.4$ Ma to $591.9 \pm 9.6$ Ma (9\% of grains; Fig. 35C), $614.6 \pm 26$ Ma to $669.5 \pm 12.3$ Ma, (10 \% of grains; Fig. 35C), and $947.6 \pm 17.3 \mathrm{Ma}$ to $1158.9 \pm 16.3 \mathrm{Ma}(23 \%$ of grains; Fig. $35 \mathrm{C})$. A total of 13 grains from the Devonian and Mesoproterozoic to Neoarchean periods in the sample do not form a distinct age population and ranges from 321 to $396 \mathrm{Ma}$ and 1242 to $2709 \mathrm{Ma}$ (15\% of grains; Fig. 35A).

Figure 36 represents the comparison between the probability density and KDE curves. The curves differ in Figure 32 such that the KDE curve is a smoother overall curve due to the bandwidth used in the calculation of the KDE curve. The two curves appear to be more similar in 
low grain density portions of the curve.

All grains in this sample were analyzed at the ALC lab facilities. The youngest singlegrain age for sample 13ZA93 (YSG) maximum depositional age is $259 \pm 7.4 \mathrm{Ma}$. The youngest graphical (probability density plot) age peak controlled by more than one grain age (YPP) appears to be $265 \mathrm{Ma}(\mathrm{n}=18)$ for probability density function, and $265 \mathrm{Ma}(\mathrm{n}=19)$ for the KDE function. The mean age of the youngest two or more grains that overlap in age at $1 \sigma(\mathrm{YC} 1 \sigma)$ is $260 \pm 10 \mathrm{Ma}$ based on the two youngest grains. The mean age of the youngest three or more grains that overlap in age at $2 \sigma(\mathrm{YC} 2 \sigma)$ is $262 \pm 1.5 \mathrm{Ma}$ based on the four youngest grains. Lastly, the youngest detrital zircon age (YDZ) is $257+4.6-7.1 \mathrm{Ma}$ for this sample.

Maximum depositional ages ranged from $259 \pm 7.4$ to 265 Ma. The maximum depositional age of $262 \pm 1.5 \mathrm{Ma}$ was determined by using the YC2 $\sigma$ method (Fig. 35). The YC2 $\sigma$ method was used because it is the most statistically robust and conservative method for determining the maximum depositional age. 


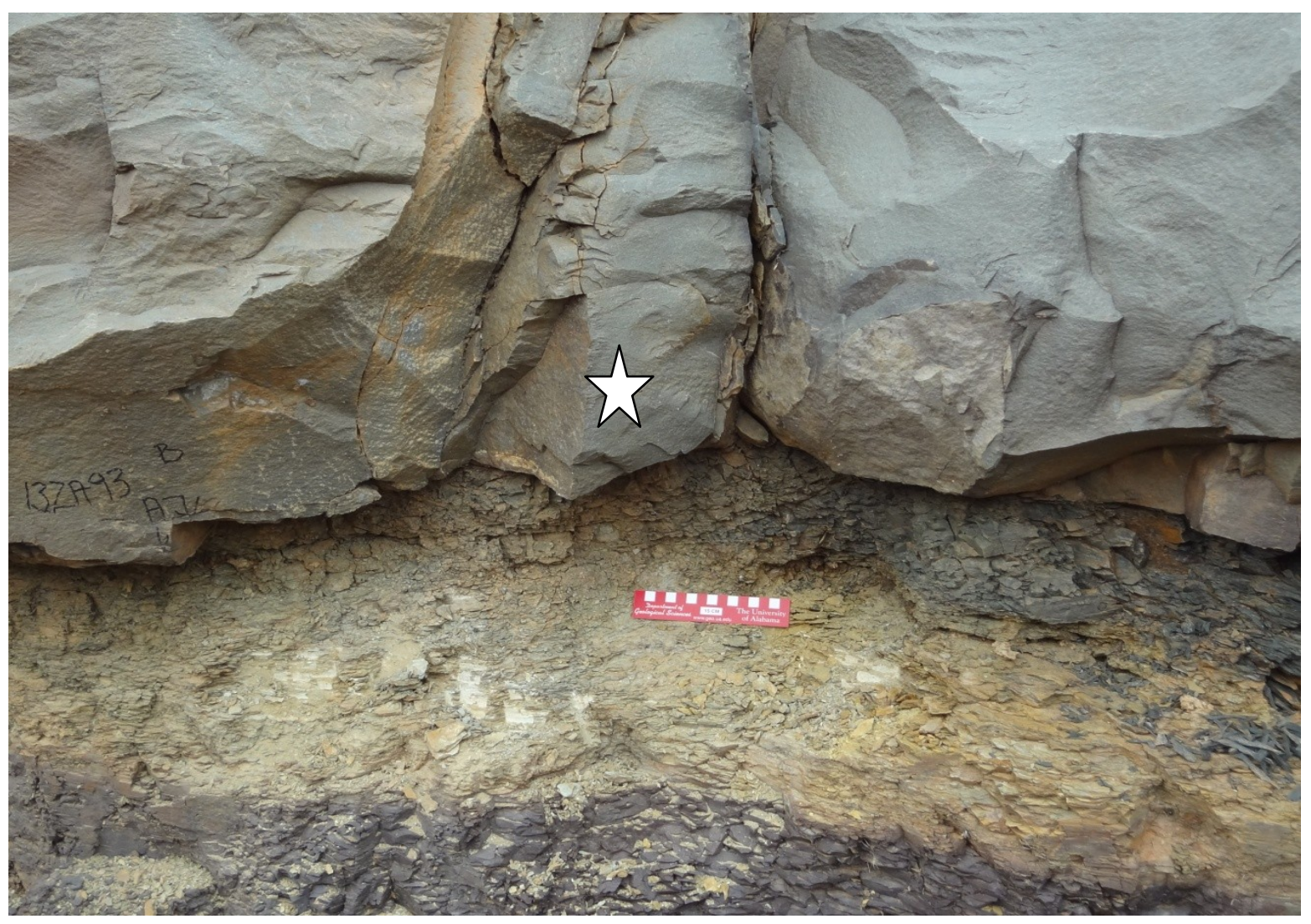

Figure 34: Out crop photograph of sample 13ZA93. The white star indicates where the sample was taken. The sample overlies an airfall ash bed. Note the dark/maroon color of the weathered surface. 

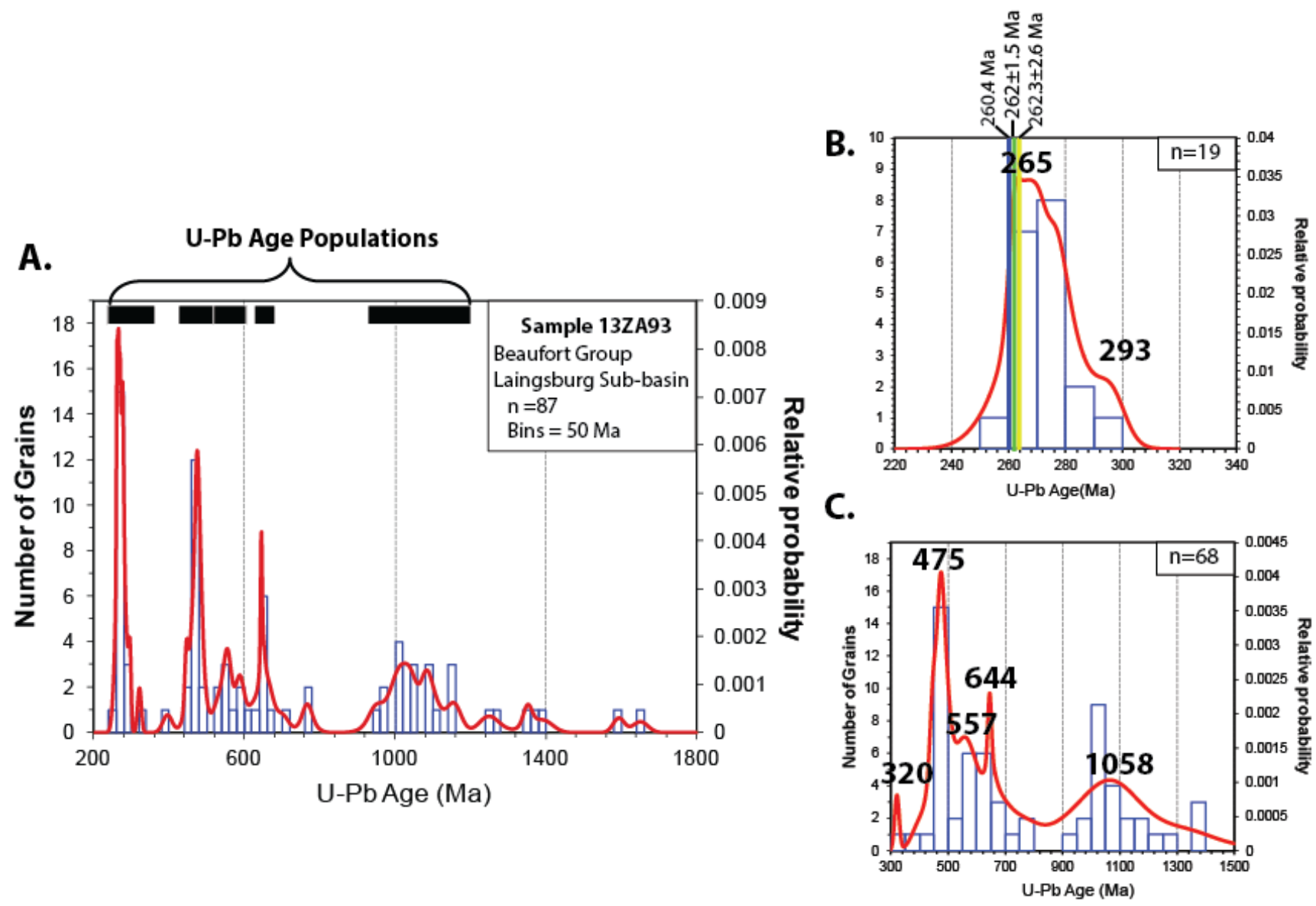

Figure 35: A) Relative probability-density curve (red) and $50 \mathrm{Ma}$ histogram bins (blue) for sample 13ZA93. B) $267-317 \mathrm{Ma}$ age population (10 Ma bins). The green line represents the maximum depositional age $(262 \pm 1.5 \mathrm{Ma})$ derived from this study. The yellow line represents an airfall ash zircon age $(262.3 \pm 2.6 \mathrm{Ma})$ collected from an ash within the same formation from McKay et al. (in review). The blue line represents the depositional age (260.4 Ma) from Retallack et al. (2006). C) 383-1289 Ma age populations (50 Ma bins). 
Number of Grains

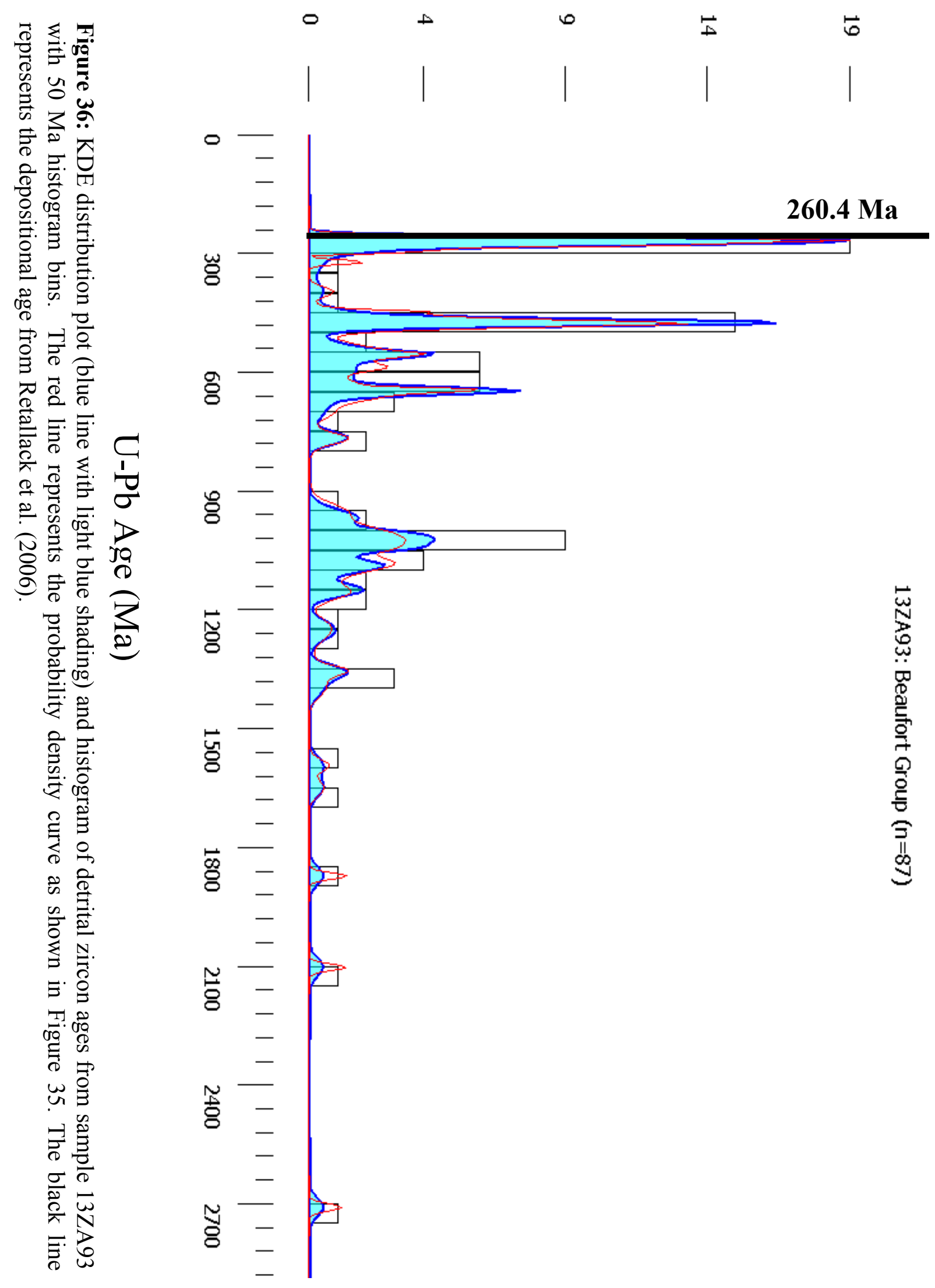




\subsubsection{Sample 13ZA68: Ripon Formation}

Sample 13ZA68 was taken from the Middle Permian (Roadian) lower Ripon Formation of the middle Ecca Group in the Ripon sub-basin (Fig. 16 \& 17). Depositional ages were determined by McKay et al. (in review) which report absolute ages from zircon grains in airfall ashes in the middle Ripon Formation of $247.7 \pm 2.2 \mathrm{Ma}$. The Ripon Formation is interpreted as turbidite deposits within the lower Ecca Group [Johnson et al., 1997]. The turbidites exhibit erosive bases which incised into underlying rock layers and had a massive texture with some prominent normally graded bedding from medium- to fine-grained sandstone. The

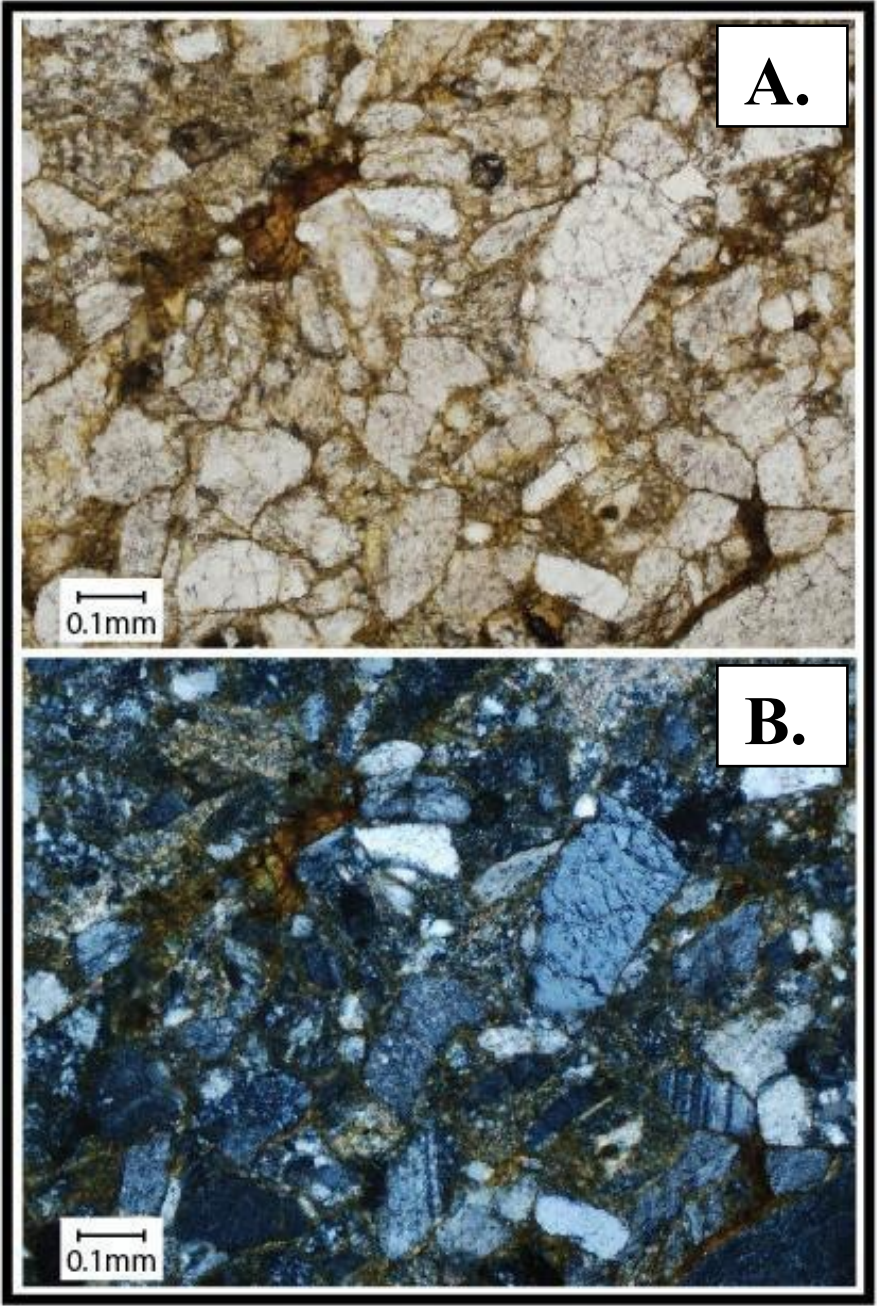

Figure 37: Thin-section image of sample 13ZA68 in plain light (A) and cross-polarized light (B). This sample consists of moderately sorted, angular to sub-angular, fine- to medium-grained sandstone. outcrop consisted mainly of medium- to thick-bedded sandstone interbedded with thin siltstone and mudstone beds. Overall the outcrop was relatively fractured with only slightly weathered surfaces appearing orange/brown and unweathered surfaces appearing light tan (Fig. 38). The sample consisted of moderately sorted, angular to sub-rounded, medium- to fine-grained sand. No distinct bedding or laminae were observed in the hand sample or thin-section (Fig. 37). The lower fan of a deepwater fan depositional setting is interpreted due to the presence of the erosive base and graded beds present 
in the outcrop caused by the failure of continental slope sediment creating high flow energies followed by an abrupt decrease in flow energy. Sandstone composition consisted of moderate quartz and abundant lithics and feldspar. Sample 13ZA68 yielded abundant zircon (thousands). Zircon grains were prismatic, transparent/colorless to slightly yellow, and ranged in size from $10-55 \mu \mathrm{m}$.

A total of 94 grains were analyzed from 13ZA68 at the UC Santa Cruz lab facilities. Analysis of sample 13ZA68 yielded 86 reliable ages. A total of eight grains were rejected due to discordance. Ages within this sample range from $263 \pm 10$ Ma to $2377 \pm 80 \mathrm{Ma}$ (Fig. 39A). In general, all ages fall within two distinct age populations which range between $263 \pm 10$ Ma to $299 \pm 12 \mathrm{Ma}$ (57 \% of grains; Fig. 39B) and $301 \pm 13$ Ma to $601 \pm 26$ Ma (30\% of grains; Fig. 39C). The 12 oldest grains in the sample do not form a distinct age population and range from $614 \pm 26$ to $2400 \mathrm{Ma}$ (13\% of grains; Fig. 39C).

Figure 40 represents the comparison between the probability density and KDE curves. The curves differ in Figure 40 such that the KDE curve is a smoother overall curve due to the bandwidth used in the calculation of the KDE curve. The two curves appear to be more similar in low grain density portions of the curve.

All grains in this sample were analyzed at the UC-SC lab facilities. The youngest singlegrain age for sample 13ZA68 (YSG) maximum depositional age is $263 \pm 10$ Ma. The youngest graphical (probability density plot) age peak controlled by more than one grain age (YPP) appears to be $276 \mathrm{Ma}(\mathrm{n}=60)$ for probability density function, and $272 \mathrm{Ma}(\mathrm{n}=63)$ for the $\mathrm{KDE}$ function. The mean age of the youngest two or more grains that overlap in age at $1 \sigma(\mathrm{YC} 1 \sigma)$ is $262 \pm 2.8$ Ma based on the two youngest grains. The mean age of the youngest three or more grains that overlap in age at $2 \sigma(\mathrm{YC} 2 \sigma)$ is $269 \pm 2.4$ Ma based on the four youngest grains. 
Lastly, the youngest detrital zircon age (YDZ) is $259+5.9-9.6$ Ma for this sample.

Maximum depositional ages ranged from $262 \pm 2.8$ to 276 Ma. The maximum depositional age of $269 \pm 2.4$ Ma was determined by using the YC2 $\sigma$ method (Fig. 39). The YC2 $\sigma$ method was used because it is the most statistically robust and conservative method for determining the maximum depositional age.

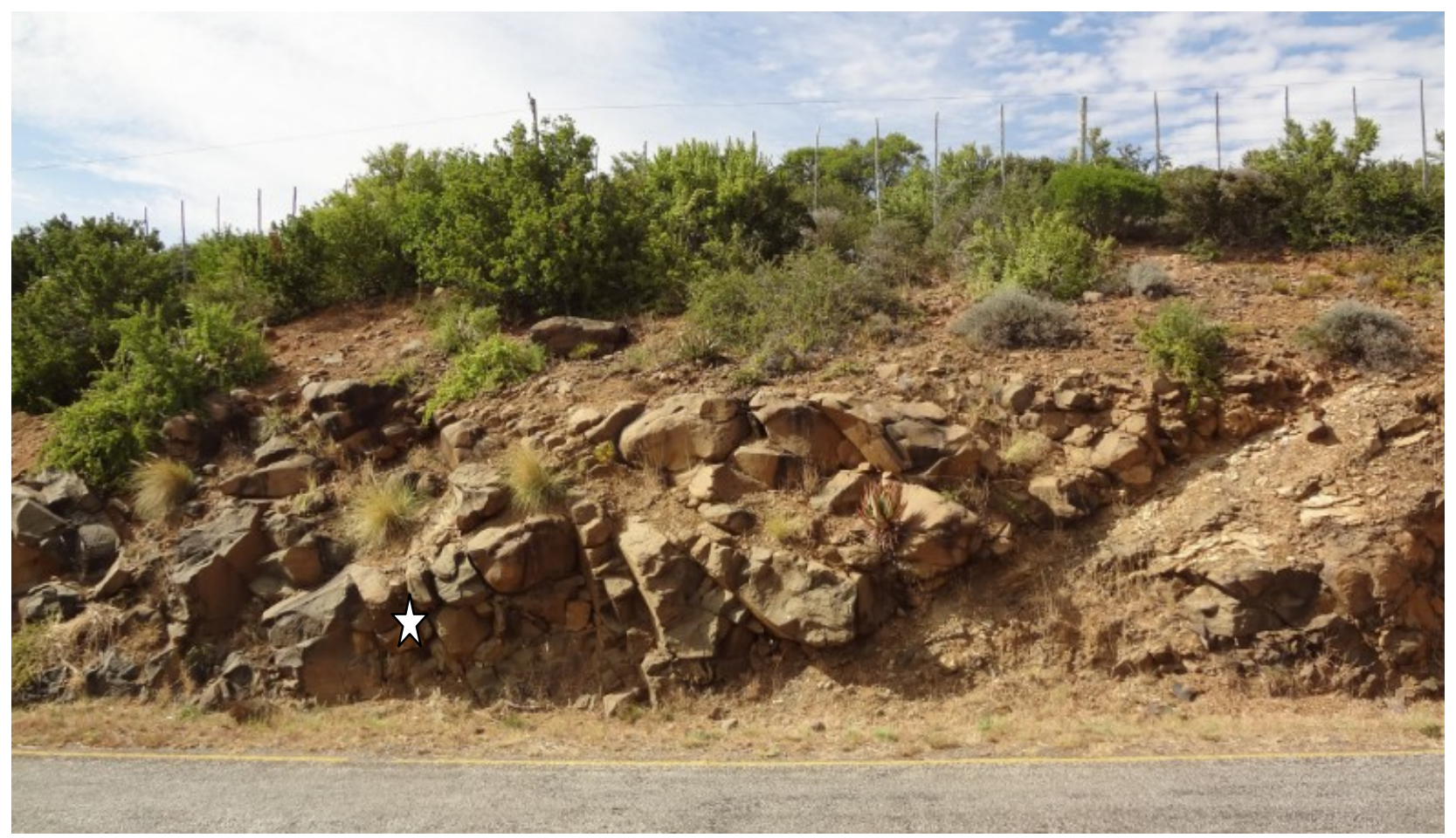

Figure 38: Outcrop photograph of the location of sample 13ZA68. The white star indicates where the sample was taken. The sample overlies an airfall ash bed. Note the fractured nature of the outcrop. 

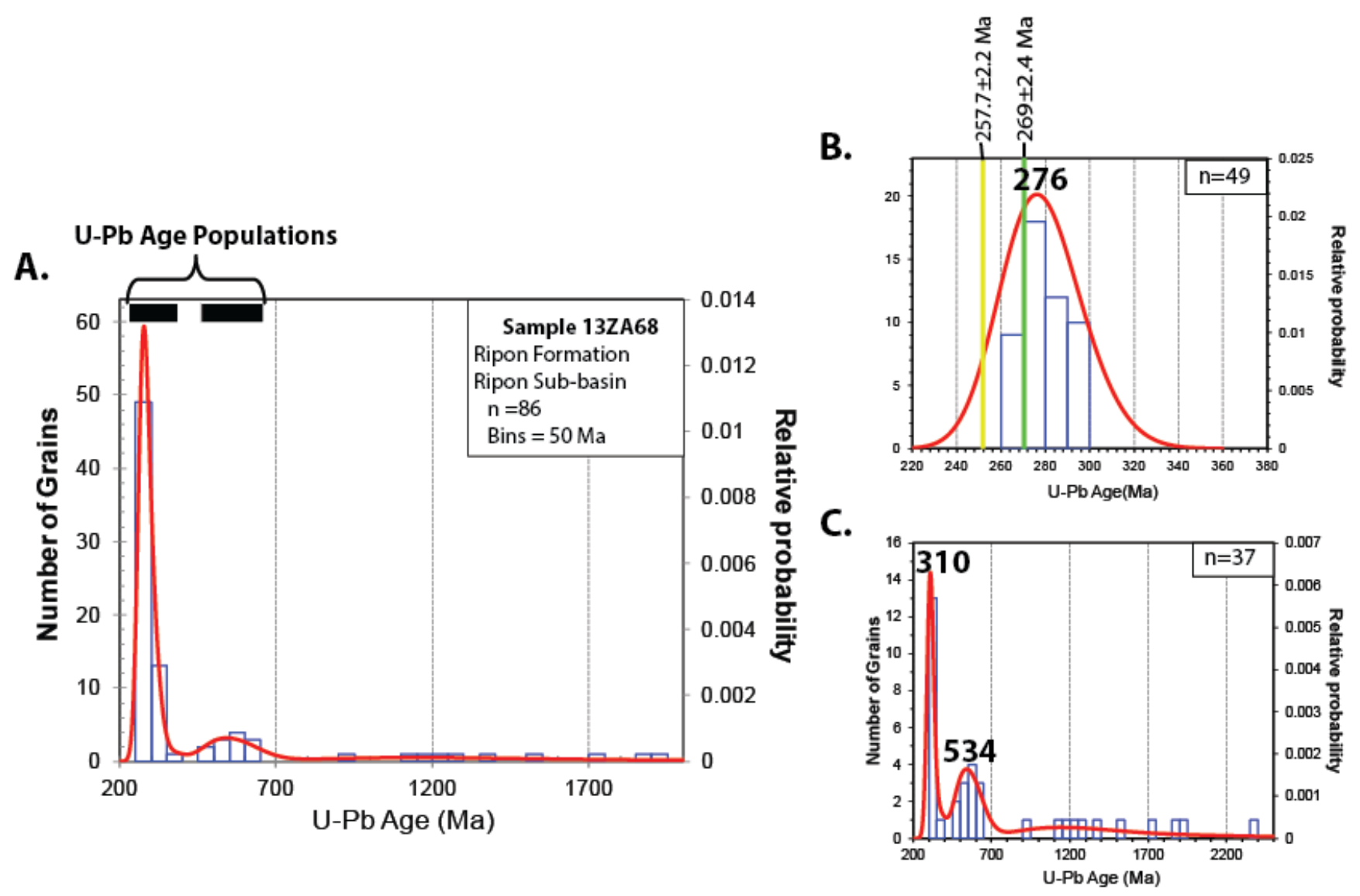

Figure 39: A) Relative probability-density curve (red) and $50 \mathrm{Ma}$ histogram bins (blue) for sample 13ZA68. B) 260-300 Ma age population (10 Ma bins). The green line represents the maximum depositional age $(269 \pm 2.4 \mathrm{Ma})$ derived from this study. The yellow line represents an airfall ash zircon age $(257 \pm 2.2 \mathrm{Ma})$ collected from an ash within the same formation from McKay et al. (in review). C) 301-2380 Ma age populations (50 Ma bins). 
Number of Grains

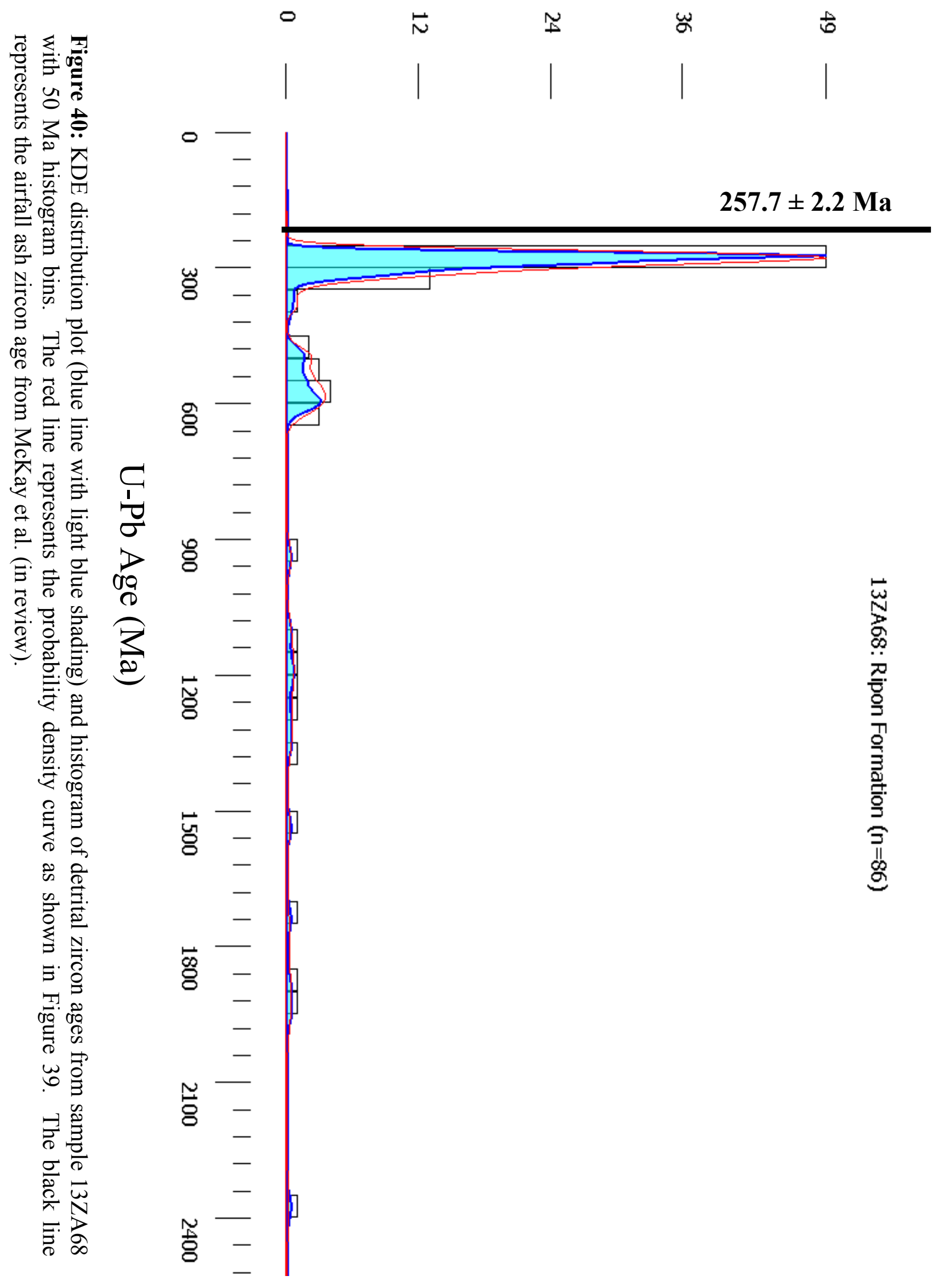




\subsubsection{Sample 13ZA74: Waterford Formation}

Sample 13ZA74 was taken

from the Late Permian

(Wuchiapingian) Waterford

Formation of the upper Ecca Group

in the Ripon sub-basin (Fig.16 \&

17). The age of the Waterford

Formation has not been

successfully determined in the

Ripon sub-basin; however, the best

age estimates come from the

Rubidge (1991) that assigned a

minimum depositional age of 255

Ma using a reptilian fossil

assemblage present in the lower

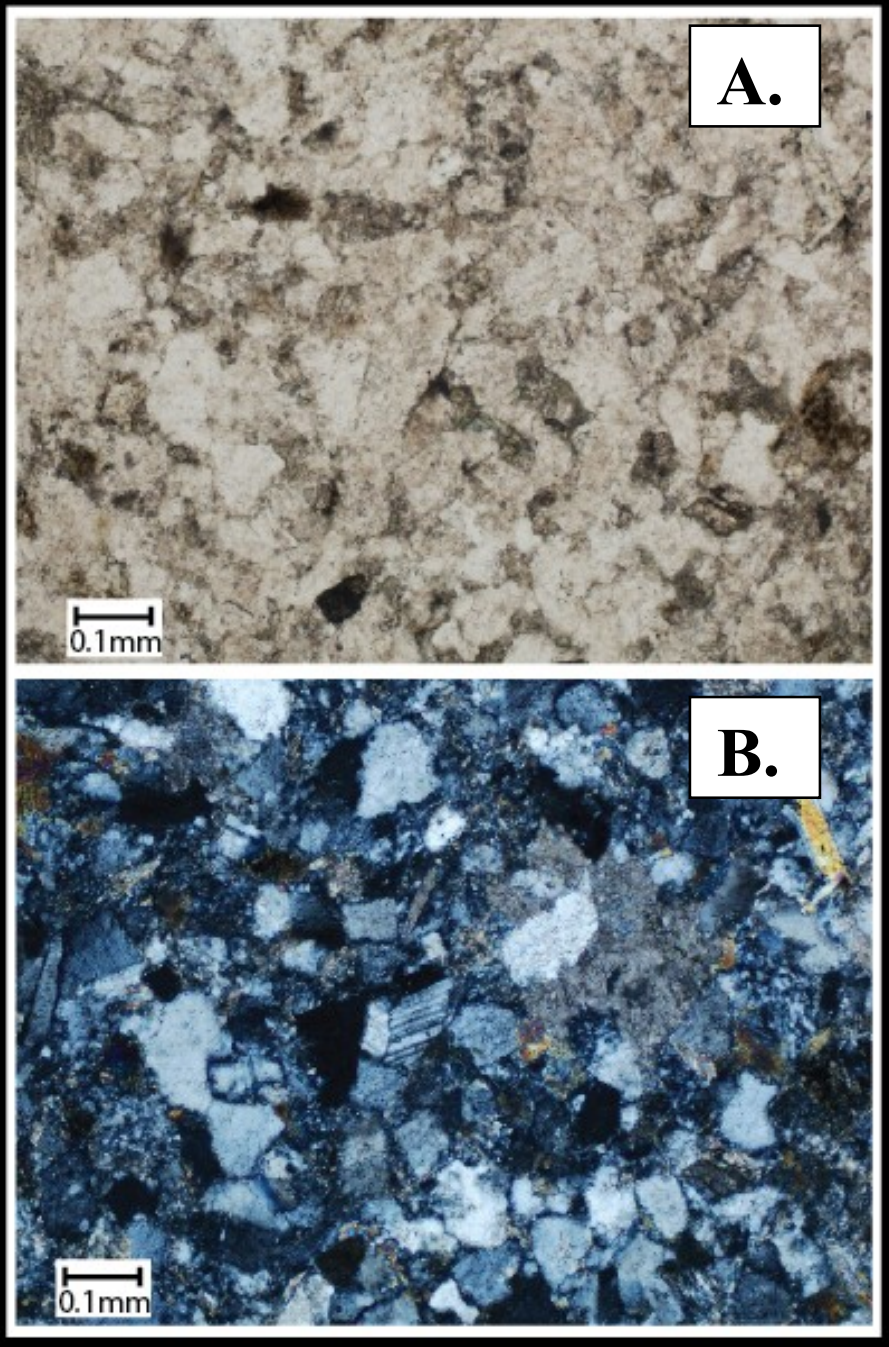

Beaufort Group. The Waterford

Figure 41: Thin-section image of sample 13ZA74 in

Formation is interpreted as deltaic

plain light (A) and cross-polarized light (B). This sample consists of moderately to well-sorted, angular deposits within the uppermost Ecca to sub-angular, fine- to medium-grained sandstone.

Group [Johnson et al., 1997]. The outcrop consisted of medium- to thick-bedded sandstones interbedded with siltstones and mudstones. Tangential cross-beds, horizontal laminae and oscillatory ripple laminations were prominent throughout the outcrop. Overall the outcrop was relatively unaltered with slightly weathered surfaces appearing black/brown and unweathered surfaces appearing light tan. The sample consisted of moderate to well sorted, angular to sub- 
rounded, medium- to fine-grained sand. No distinct bedding or laminae were observed in the hand sample or thin-section (Fig. 41). The depositional environment of the sampled portion of the Waterford Formation was likely the delta front of a wave-dominated delta based on the interbedded nature of the outcrop, trace fossils present, and oscillatory flow patterns. Sandstone composition consisted of moderate quartz and abundant lithics and feldspar. Sample 13ZA74 yielded abundant zircon (thousands). Zircon grains were prismatic, transparent/colorless to slightly yellow, and ranged in size from $10-50 \mu \mathrm{m}$.

A total of 109 grains were analyzed from sample 13ZA74 at the UC Santa Cruz lab facilities. Analysis of sample 13ZA74 yielded 97 reliable ages. A total of 12 grains were rejected with seven grains rejected due to high ${ }^{204} \mathrm{~Pb}$ concentration and five grains rejected due to discordance. Ages within this sample range from $263 \pm 6$ Ma to $2032 \pm 43$ Ma (Fig. 42A). In general, all ages fall within three distinct age populations which range between $263 \pm 6$ Ma to $309 \pm 7 \mathrm{Ma}$ (50 \% of grains; Fig. 42B) $342 \pm 8$ Ma to $791 \pm 19$ Ma (34\% of grains; Fig. 42C) and $920 \pm 20$ to $1154 \pm 25$ (13\% of grains; Fig. $42 \mathrm{C})$. The three oldest grains in sample 13ZA74 do not form a distinct age population and range from 1325 to 2000 Ma (3 \% of grains; Fig. 42A).

Figure 43 represents the comparison between the probability density and KDE curves. The curves differ in Figure 40 such that the KDE curve is a smoother overall curve due to the bandwidth used in the calculation of the KDE curve. The two curves appear to be more similar in low grain density portions of the curve.

All grains in this sample were analyzed at the UC-SC lab facilities. The youngest singlegrain age for sample 13ZA74 (YSG) maximum depositional age is $263 \pm 6$ Ma. The youngest graphical (probability density plot) age peak controlled by more than one grain age (YPP) appears to be $274 \mathrm{Ma}(\mathrm{n}=57)$ for probability density function, and $274 \mathrm{Ma}(\mathrm{n}=47)$ for the KDE 
function. The mean age of the youngest two or more grains that overlap in age at $1 \sigma(\mathrm{YCl} \sigma)$ is $264 \pm 5 \mathrm{Ma}$ based on the two youngest grains. The mean age of the youngest 12 or more grains that overlap in age at $2 \sigma(\mathrm{YC} 2 \sigma)$ is $266 \pm 2$ Ma based on the 12 youngest grains. Lastly, the youngest detrital zircon age (YDZ) is $259+3.8-5.2 \mathrm{Ma}$ for this sample.

Maximum depositional ages ranged from $263 \pm 9$ to 274 Ma. The maximum depositional age of $266 \pm 2$ Ma was determined by using the YC2 $\sigma$ method (Fig. 39). The YC2 $\sigma$ method was used because it is the most statistically robust and conservative method for determining the maximum depositional age.
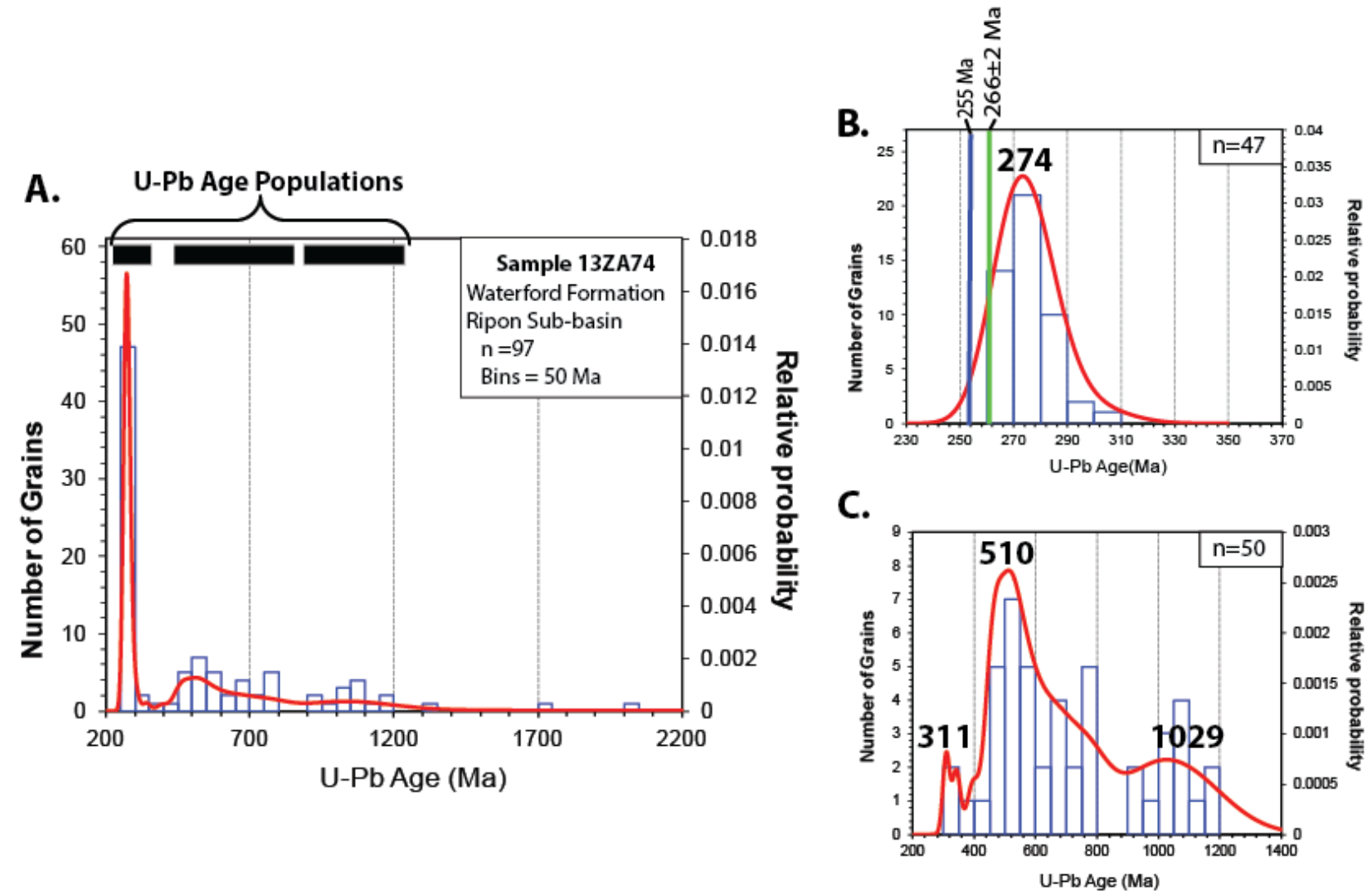

Figure 42: A) Relative probability-density curve (red) and 50 Ma histogram bins (blue) for sample 13ZA74. B) 260-310 Ma age population (10 Ma bins). The green line represents the maximum depositional age $(262 \pm 2 \mathrm{Ma})$ derived from this study and the blue line represents the depositional age (255 Ma) from Rubidge (1991). C) 310-2050 Ma age populations (50 Ma bins). 


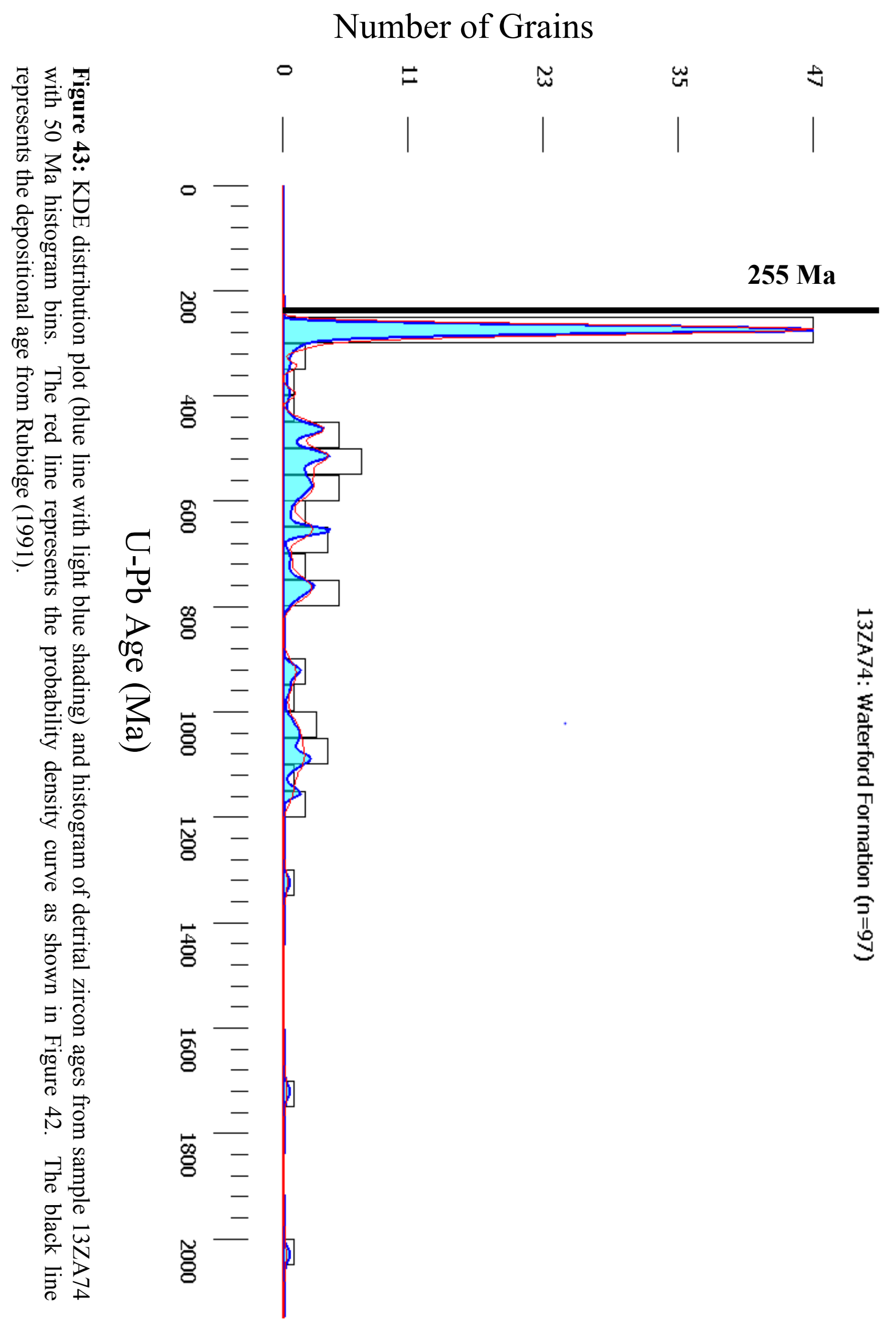




\subsection{U-Pb Age Population Correlation}

Seven U-Pb detrital zircon samples display several similar major age populations. Figure 44 shows normalized relative probability density plots for all seven samples highlighting the similarity of pre- and post $300 \mathrm{Ma}$ age populations each sample. Figure 45 displays pie charts of grains within Phanerozoic, Proterozoic, and Archean geologic time periods. In general, the Permian age population is present in all seven samples whereas populations greater than $300 \mathrm{Ma}$ vary from sample to sample. Triassic age populations are present in two samples (12ZA13: Tanqua sub-basin and 12ZA26: Laingsburg sub-basin) (Fig. 45). Several single grains are present in all samples that do not form prominent age populations (Fig. 44). 


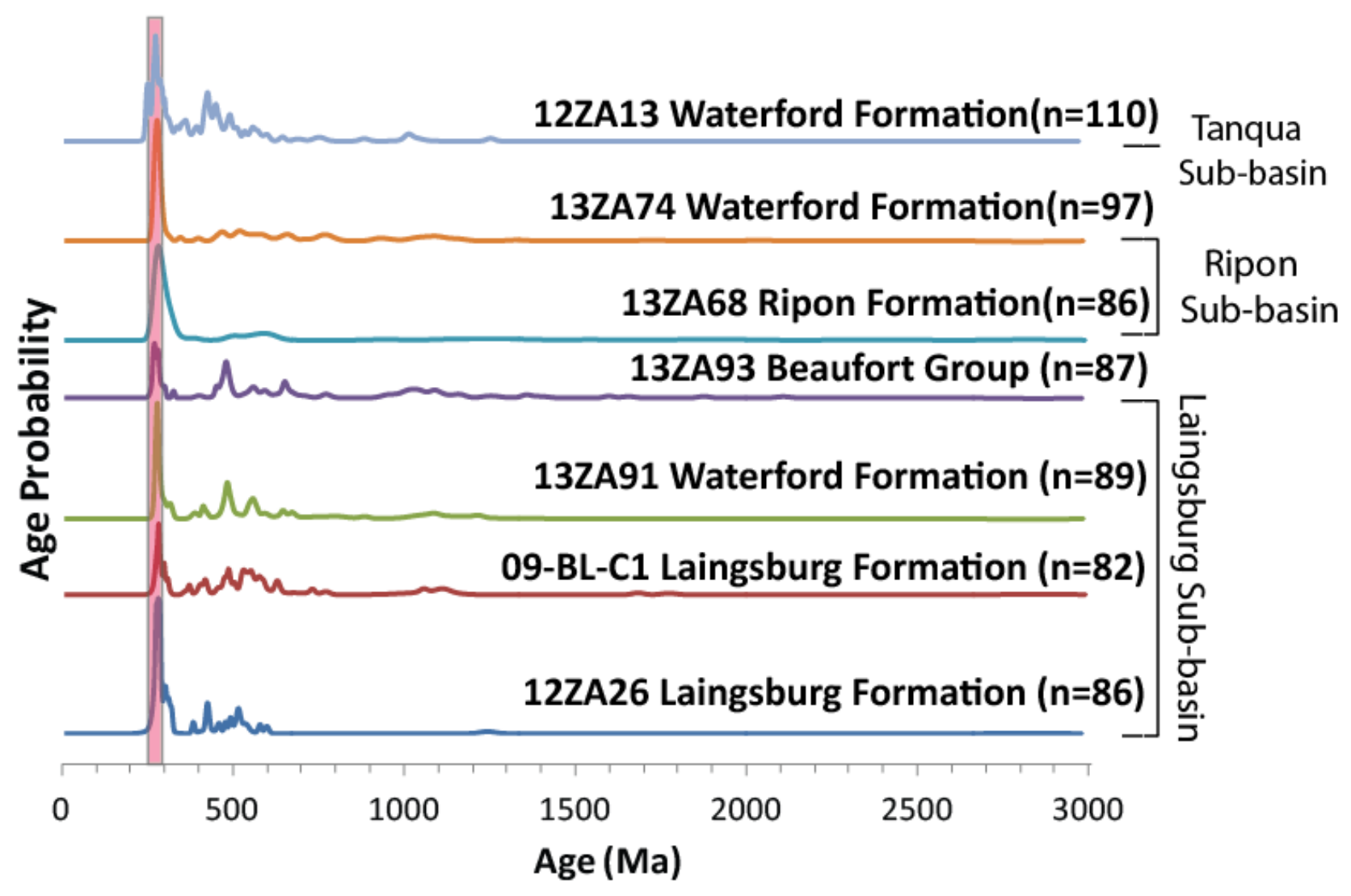

Figure 44: Normalized probability density plot of all seven U-Pb detrital zircon samples. The red box represents the time period (255-270 Ma) in which lower Beaufort Group, Waterford Formation, Laingsburg Formation and Ripon Formation was deposited [from Rubidge et al., 1999; Turner, 1999]. The various colored curves represent the $\mathrm{U}-\mathrm{Pb}$ age distribution for each sample. 


\subsection{Kolmogorov-Smirnoff Test}

K-S test results for each sample reveal numerous statistical similarities in source affinity between samples. P-values for samples range in similarity from 0.061 to0.99 (Table 2). It is important to keep in mind that K-S tests do not account for age errors and that the dispersal of age data may affect the P-value result because poorly characterized samples can yield spuriously small p-values, particularly if a zircon age population is absent, over-represented, or underrepresented in a sample distribution.

Several relationships between the geographic and temporal distribution of samples and associated p-values are observed. In general, samples from the Laingsburg sub-basin vary greatly in similarity to one another with p-values ranging from 0.2 to 0.98 . The Waterford Formation (13ZA91) and the upper Laingsburg Formation (09-BL-C1) appear to have the most similar source affinity with a p-value of 0.98 . The lower Beaufort Group (13ZA93) is also similar to the Laingsburg Formation (12ZA26) with a p-value of 0.86. The Beaufort Group appears to become slightly dissimilar to the source affinity of strata up-section underlying (Upper Laingsburg and Waterford Formation) the Beaufort Group with p-values ranging from 0.26 to 0.38 . The Laingsburg and Waterford Formations are likely to have shared a similar source with p-values ranging from 0.2 to 0.98 .

Sample 12ZA13 (Waterford Formation) was the only sample collected from the Tanqua sub-basin. Detrital zircon age distributions of this sample is highly similar to the detrital zircon age distributions of two samples of the Laingsburg sub-basin, 12ZA26 (Laingsburg Formation) and 13ZA93 (Beaufort Group) which return p-values of 0.79 and 0.93 when compared to 12ZA13. The Sediment source of these samples likely differed from that of the upper Laingsburg Formation (09-BL-C1) and Waterford Formation (13ZA91) samples of the Laingsburg sub-basin 
and the Ripon Formation (13ZA68) and Waterford Formation (13ZA74) samples of the Ripon sub-basin as demonstrated by p-values ranging from 0.061 to 0.29 .

Samples from the Laingsburg sub-basin also vary greatly in similarity to samples in the Ripon sub-basin with p-values ranging from 0.16 to 0.99 . The two samples from the Ripon subbasin contain slightly similar source affinities to one another with a p-value of 0.23 . The Ripon Formation (13ZA68) sample is likely to have been sourced from the same parent rock as the Laingsburg (12ZA26 and 09-BL-C1) and Waterford (13ZA91) Formations in the Laingsburg sub-basin with p-values ranging from 0.56 to 0.98 . However, the Ripon Formation appears to be slightly dissimilar to the Waterford Formation (12ZA13) in the Tanqua sub-basin and the Beaufort Group in the Laingsburg sub-basin demonstrated by p-values of 0.16 and 0.31 respectively. The Waterford Formation (13ZA74) is likely to have been sourced from the same parent rock as the upper Laingsburg (09-BL-C1) and Waterford Formations (13ZA91) and the Beaufort Group (13ZA93) in the Laingsburg sub-basin with p-values of $0.50,0.85$ and $0.97 \%$ respectively. The Waterford Formation is dissimilar to the Ripon Formation (13ZA68) in the Ripon sub-basin and the Laingsburg Formation (12ZA26) in the Laingsburg sub-basin with pvalues of 0.23 and 0.34 .

Samples collected from the Waterford Formation in the Tanqua, Laingsburg, and Ripon sub-basins exhibit p-values ranging from 0.61 to 0.85 . The Waterford Formation from the Tanqua sub-basin is slightly similar to the Waterford Formation sample within Laingsburg and Ripon sub-basin with p-values of 0.61 and 0.29 . The Waterford Formation in the Laingsburg and Ripon sub-basins are highly similar to one another with a p-value of 0.85 indicating that they were likely sourced from the sample parent rock.

Samples collected from the middle Ecca Group in the Laingsburg and Ripon range yield 
p-values ranging from 0.48 to 0.99 , reflecting a high likelihood of shared parent source for these samples. The two Laingsburg sub-basin samples (12ZA26 and 09-BL-C1) are similar to one another $(\mathrm{p}$-value $=0.49)$ and to the Ripon sub-basin sample $(13 Z \mathrm{ZA68})$ with p-values of $0.56 \%$ and 0.99 .

Only one sample was collected from the lower Beaufort Group but ranges in similarity to other samples with p-values ranging from 0.31 to 0.97 . The Beaufort Group sample (13ZA93) is the most similar to the Waterford Formation samples in both the Laingsburg (13ZA91) and Ripon (13ZA74) sub-basin, returning p-values of 0.79 and 0.97.

Table 4: K-S Test results

\begin{tabular}{|c|c|c|c|c|c|c|c|}
\hline & & & & & & & \\
\hline & & & & & & & \\
\hline Age (Ma) & 255 * & $270.1 \pm 2 \neq$ & $248.9 \pm 2.6 \neq$ & $255^{*}$ & $262.3 \pm 2.6 \neq$ & $257.7 \pm 2.2 ¥$ & $255^{*}$ \\
\hline Formation & Waterford & Laingsburg & Laingsburg & Waterford & Beaufort Grp & Ripon & Waterford \\
\hline Sub-basin & Tanqua & Laingsburg & Laingsburg & Laingsburg & Laingsburg & Ripon & Ripon \\
\hline $12 Z A 13$ & & 0.928 & 0.082 & 0.061 & 0.790 & 0.155 & 0.288 \\
\hline 12ZA26 & & & 0.458 & 0.202 & 0.860 & 0.560 & 0.338 \\
\hline 09-BL-C1 & & & & 0.984 & 0.258 & 0.989 & 0.500 \\
\hline 13ZA91 & & & & & 0.380 & 0.967 & 0.853 \\
\hline 13ZA93 & & & & & & 0.305 & 0.967 \\
\hline 13ZA68 & & & & & & & 0.226 \\
\hline 13ZA74 & & & & & & & \\
\hline
\end{tabular}

* = Depositional age from Rubidge et al. (1999)

$\neq=$ Airfall ash age from Fildani et al. (2008 \&2009)

$¥=$ Airfall ash age from McKay et al. (in review)

\subsection{Maximum Depositional Ages}

Depositional ages for the Permian/Triassic Karoo basin fill have been established by previous studies which used biostratigraphic paleobotanical, paleopedological, carbon isotopic, 
and radiometric dating methods. The depositional age for the Laingsburg Formation in the Laingsburg sub-basin has been estimated using radiometric dating methods. Turner (1999) established that the age of $270 \pm 1$ Ma for the Collingham Formation in the Laingsburg sub-basin using radiometric dating methods on zircons from tuffs within the Laingsburg Formation in the Laingsburg sub-basin but the age was non-repeatable. Studies conducted by Fildani et al. (2007; 2009) reports absolute ages for the Laingsburg Formation ranging from $270.1 \pm 2$ to $248.9 \pm 2.6$ Ma by dating zircon grains in airfall ashes. A study conducted by Rubidge (1991) using biostratigraphy to conclude that the depositional age of the lower Beaufort Group in the Tanqua and Laingsburg sub-basins was approximately 255 Ma based on the presence of an Eodicynodon reptilian fossil assemblage. Another depositional age of 260.4 Ma by Retallack et al. (2006) was determined for the Beaufort Group by using carbon isotope chemostratigraphy. The depositional age of the Ripon Formation (13ZA68) in the Ripon sub-basin has been dated by a recent study conducted by McKay et al. (in review) which reports ages of zircon grains found in airfall ashes in the Ripon Formation of $257.7 \pm 2.2$ Ma.

Maximum depositional ages were determined from detrital zircon ages using the methods outlined by Dickinson and Gehrels (2009) (Table 3). Each method varies in accuracy and reproducibility. For example the YSG method may be misleading because a single data point in an analytical matrix may be spurious, whereas the $\mathrm{YC} 2 \sigma$ method, which is the most conservative estimate because using a cluster of ages reduces the effect of lead loss [Dickinson and Gehrels, 2009].

The maximum depositional ages for the Laingsburg Formation (12ZA26 and 09-BL-C1) in the Laingsburg sub-basin date to $265 \pm 4.4 \mathrm{Ma}$ and $270 \pm 5 \mathrm{Ma}$, respectively, using the YC2 $\sigma$ method. The maximum depositional age for the Ripon formation from this study is $269 \pm 2.4$ 
using the YC2 $\sigma$ method and $263 \pm 10$ using the YSG method. The maximum depositional age of the Waterford Formation (12ZA13) in the Tanqua sub-basin of $249 \pm 3.8 \mathrm{Ma}$, determined by the YC2 $\sigma$ method, is younger than the maximum depositional age of the Waterford Formation in the Laingsburg (13ZA91) and Ripon (13ZA74) sub-basins of $269 \pm 2$ Ma determined by the YC2 $\sigma$ method and of $262 \pm 2$ Ma determined by the YC2 $\sigma$ method, respectively (Table 3). The maximum depositional age of the lower Beaufort Group (13ZA93) in the Laingsburg sub-basin is constrained by a YC2 $\sigma$ age of $262 \pm 1.5 \mathrm{Ma}$ and a YSG age of $259 \pm 7.4 \mathrm{Ma}$.

Table 5: Maximum depositional ages of all detrital zircon samples.

\begin{tabular}{|c|c|c|c|c|c|c|c|c|c|}
\hline Sample & $\begin{array}{c}\text { Formation/ } \\
\text { Group }\end{array}$ & Sub-basin & $\begin{array}{c}\text { Depositional } \\
\text { Age (Ma) }\end{array}$ & YSG (Ma) & $\begin{array}{c}\text { YPP (Ma) } \\
\text { (Probability } \\
\text { Density) }\end{array}$ & $\begin{array}{c}\text { YPP (Ma) } \\
\text { (KDE) }\end{array}$ & YClo (Ma) & YC2 $\sigma$ (Ma) & YDZ (Ma) \\
\hline $12 \mathrm{ZA} 13$ & Waterford & Tanqua & $255^{\mathrm{a}}$ & $245 \pm 6.5$ & $247(n=43)$ & $269(n=37)$ & $245.6 \pm 8.5(n=3)$ & $249 \pm 3.8(n=4)$ & $245,+5.4-6.8$ \\
\hline $12 \mathrm{ZA} 26$ & \begin{tabular}{|l} 
Laingsburg \\
\end{tabular} & Laingsburg & $255-270^{b}$ & $252 \pm 19.6$ & $255(n=41)$ & $272(n=36)$ & $259 \pm 19(\mathrm{n}=2)$ & $265 \pm 4.4(n=4)$ & $254,+9.6-24$ \\
\hline 09-BL-C1 & Laingsburg & Laingsburg & $255-270^{b}$ & $265 \pm 12$ & $278(\mathrm{n}=22)$ & $275(n=36)$ & $271 \pm 10(\mathrm{n}=3)$ & $270 \pm 5(\mathrm{n}=3)$ & $266,+5.8-14$ \\
\hline 13ZA91 & Waterford & Laingsburg & $255^{\mathrm{a}}$ & $267 \pm 5.1$ & $274(n=25)$ & $274(n=29)$ & $270 \pm 3.4(n=4)$ & $269 \pm 2(n=9)$ & $266,+2.7-5.2$ \\
\hline 13ZA93 & Beaufort & Laingsburg & $260.4^{c}$ & $259 \pm 7.4$ & $265(n=(18)$ & $265(n=19)$ & $260 \pm 10(n=2)$ & $262 \pm 1.5(n=4)$ & $257,+4.6-7.1$ \\
\hline $13 \mathrm{ZA} 68$ & Ripon & Ripon & $257.7 \pm 2.2^{d}$ & $263 \pm 10$ & $276(n=60)$ & $272(n=49)$ & $269.2 \pm 4.9(\mathrm{n}=16)$ & $269 \pm 2.4(n=16)$ & $259,+5.9-9.6$ \\
\hline 13ZA74 & Waterford & Ripon & $255^{\mathrm{a}}$ & $263 \pm 6$ & $274(\mathrm{n}=57)$ & $274(\mathrm{n}=47)$ & $265.9 \pm 3.6(n=12)$ & $266 \pm 2(n=12)$ & $259,+3.8-5.2$ \\
\hline
\end{tabular}

YSG $=$ Youngest single grain age YPP= Youngest graphical age population: probability density and KDE distributions $\mathrm{YC} 1 \sigma=$ mean age of the youngest two overlapping grain ages or more at $1 \sigma$ $\mathrm{YC} 2 \sigma=$ mean age of the youngest three overlapping grain ages or more at $2 \sigma$ YDZ= Youngest detrital zircon [Ludwig, 2012] a $=$ Depositional age from Rubidge et al. (1999).

$\mathrm{b}=$ Depositional age from Rubidge et al. (1999) and Radiometric age from Turner (1999)

${ }^{c}=$ Depositional age from Retallack et al. (2006)

$\mathrm{d}=$ Airfall ash age from McKay et al. (in review) 


\subsection{Metamorphic Versus Igneous Zircon}

In order to determine whether zircon grains were igneous or metamorphic in origin, $\mathrm{U}-\mathrm{Pb}$ age versus U/Th ratio cross plots were made (Fig. 46). Metamorphic zircons were identified by those with a U/Th ratio of $>4$. Metamorphic zircons were present in all seven samples (55 grains out of 553 total grains; $\sim 10 \%$ ), however, age and amount of metamorphic zircons varied in each sample. Metamorphic zircons from all of the samples were combined and a probability density plot was generated to represent any prominent metamorphic age populations within Karoo basinfill (Fig. 47). Metamorphic zircons range in age from $260.6 \pm 11$ Ma to $2377 \pm 80$ Ma. Cambrian to Neoproterozoic aged zircon populations are present in samples three samples, 09BL-C1 ( $\sim 10 \%$ of grains), 13ZA93 ( $\sim 6 \%$ of grains), and 13ZA74 ( $\sim 9 \%$ of grains). Metamorphic grains within this age range are present in the other four samples; however, no coherent age population is present. 
12ZA13: Waterford Formation

Tanqua sub-basin

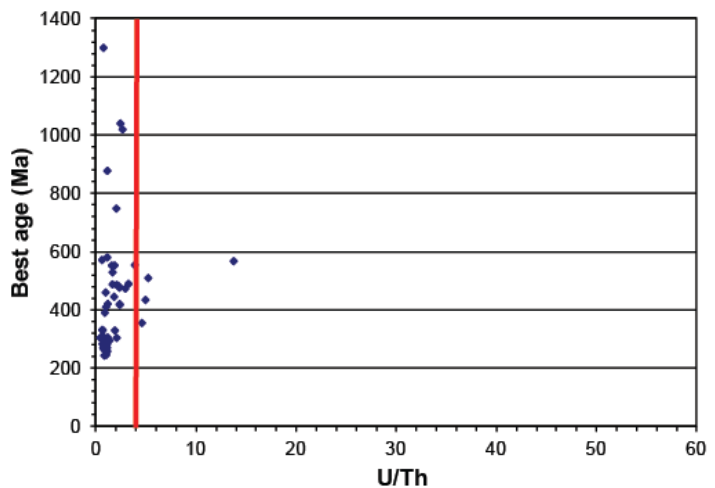

09-BL-C1: Laingsburg Formation Laingsburg sub-basin

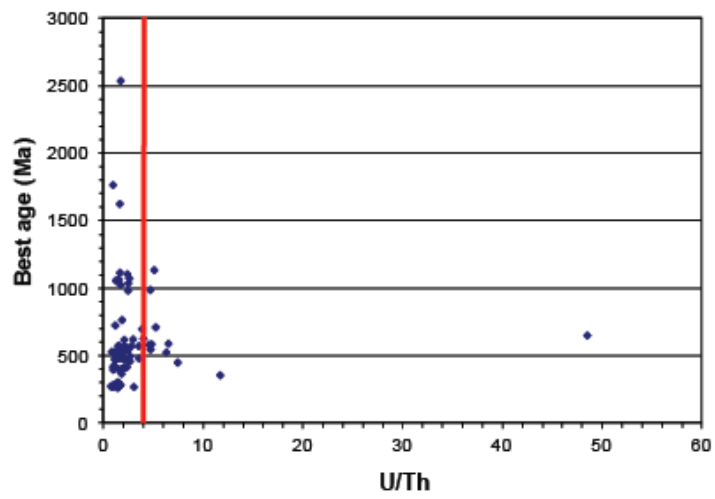

13ZA93: Beaufort Group

Laingsburg sub-basin

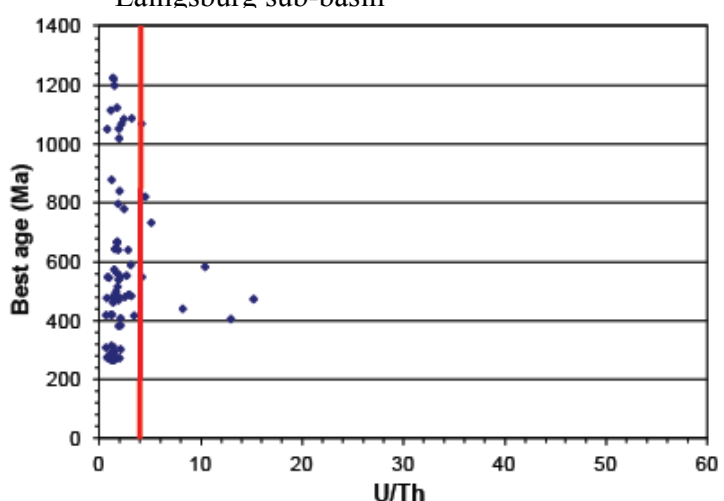

12ZA26: Laingsburg Formation

Laingsburg sub-basin

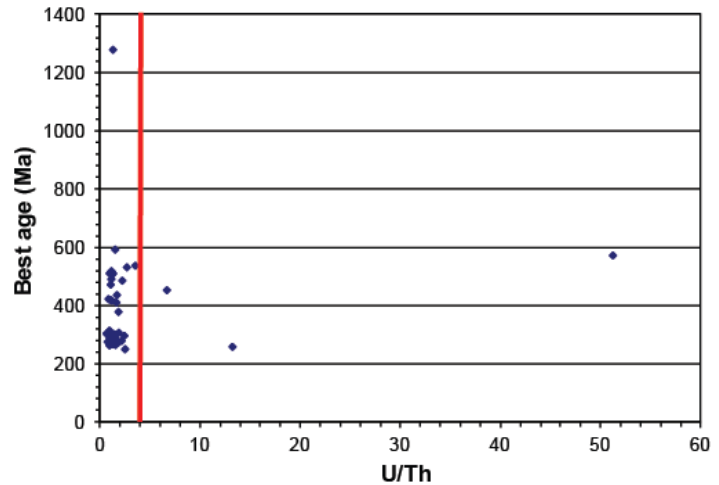

13ZA91: Waterford Formation Laingsburg sub-basin

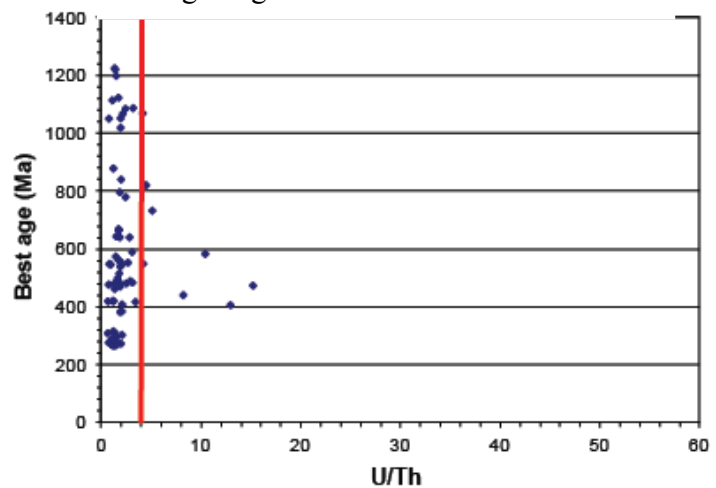

13ZA68: Ripon Formation

Ripon sub-basin

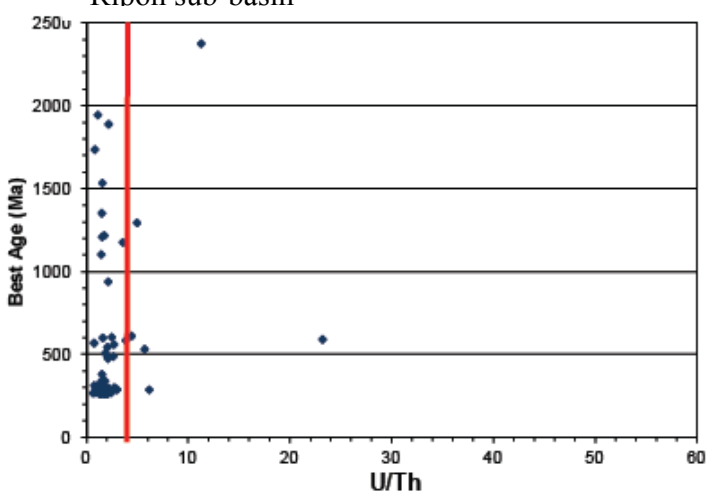

13ZA74: Waterford Formation Ripon sub-basin

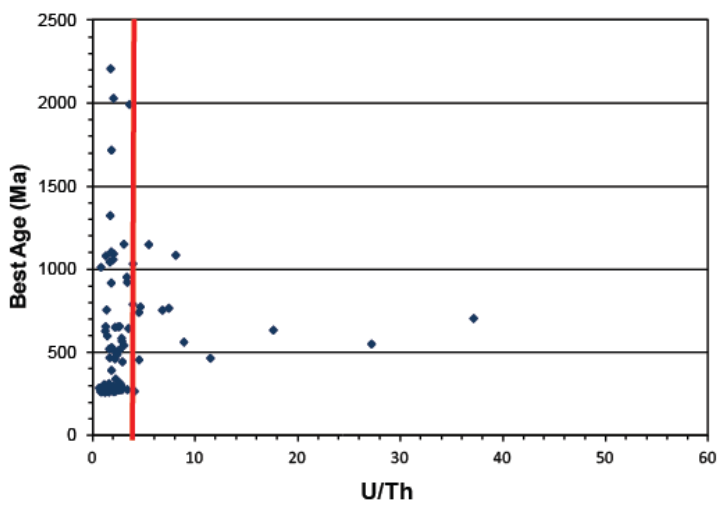

Figure 46: $\mathrm{U}-\mathrm{Pb}$ age versus $\mathrm{U} / \mathrm{Th}$ ratio plots for all seven $\mathrm{U}-\mathrm{Pb}$ detrital zircon samples. The red line represents a $\mathrm{U} / \mathrm{Th}$ ratio of 4 . If grains have a $\mathrm{U} / \mathrm{Th}$ ratio $>4$, the grain is likely metamorphic in origin. 


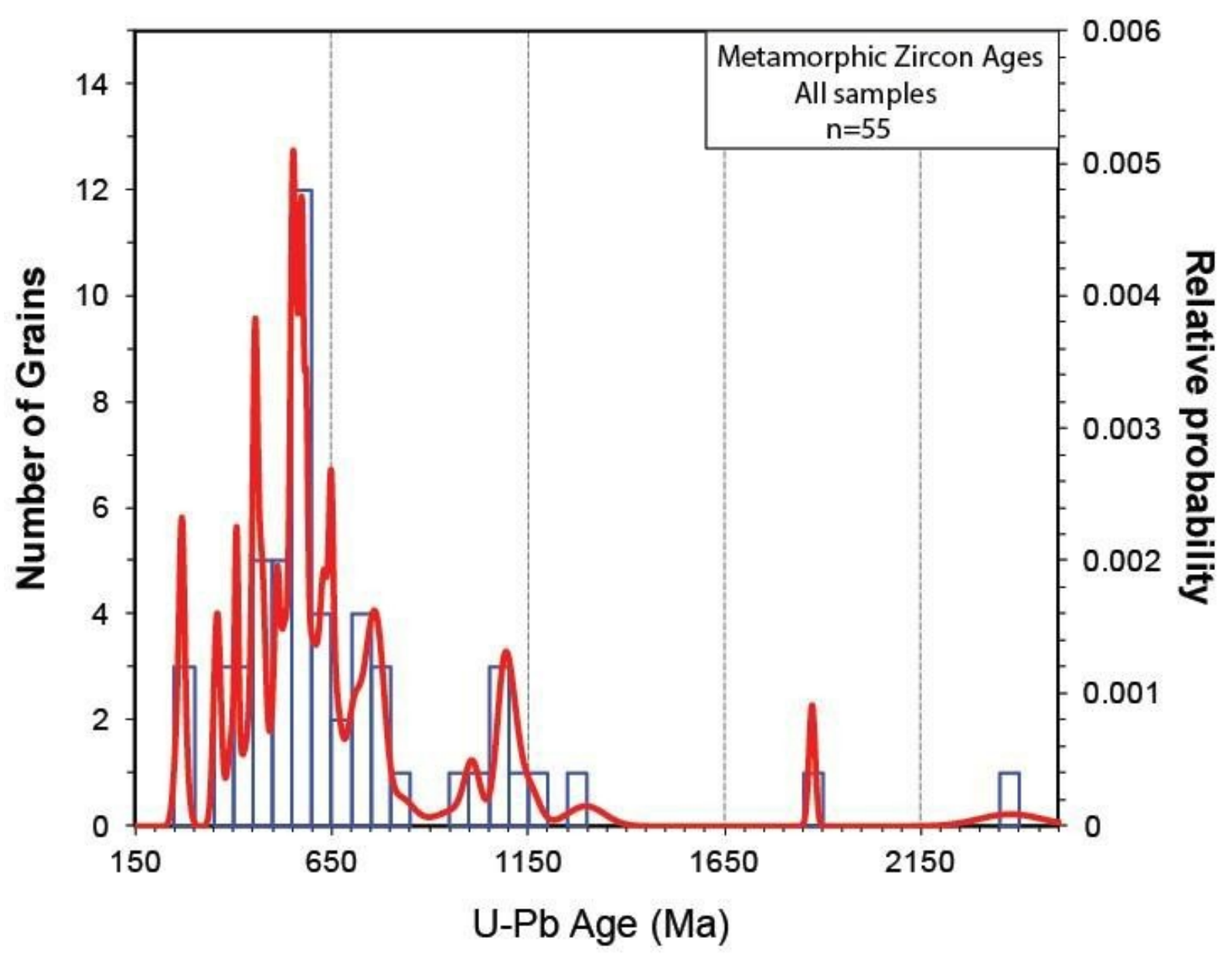

Figure 47: Probability density plot of 55 metamorphic zircon grains from all seven U-Pb detrital zircon samples. Note the prominent Cambrian to Neoproterozoic age population. 


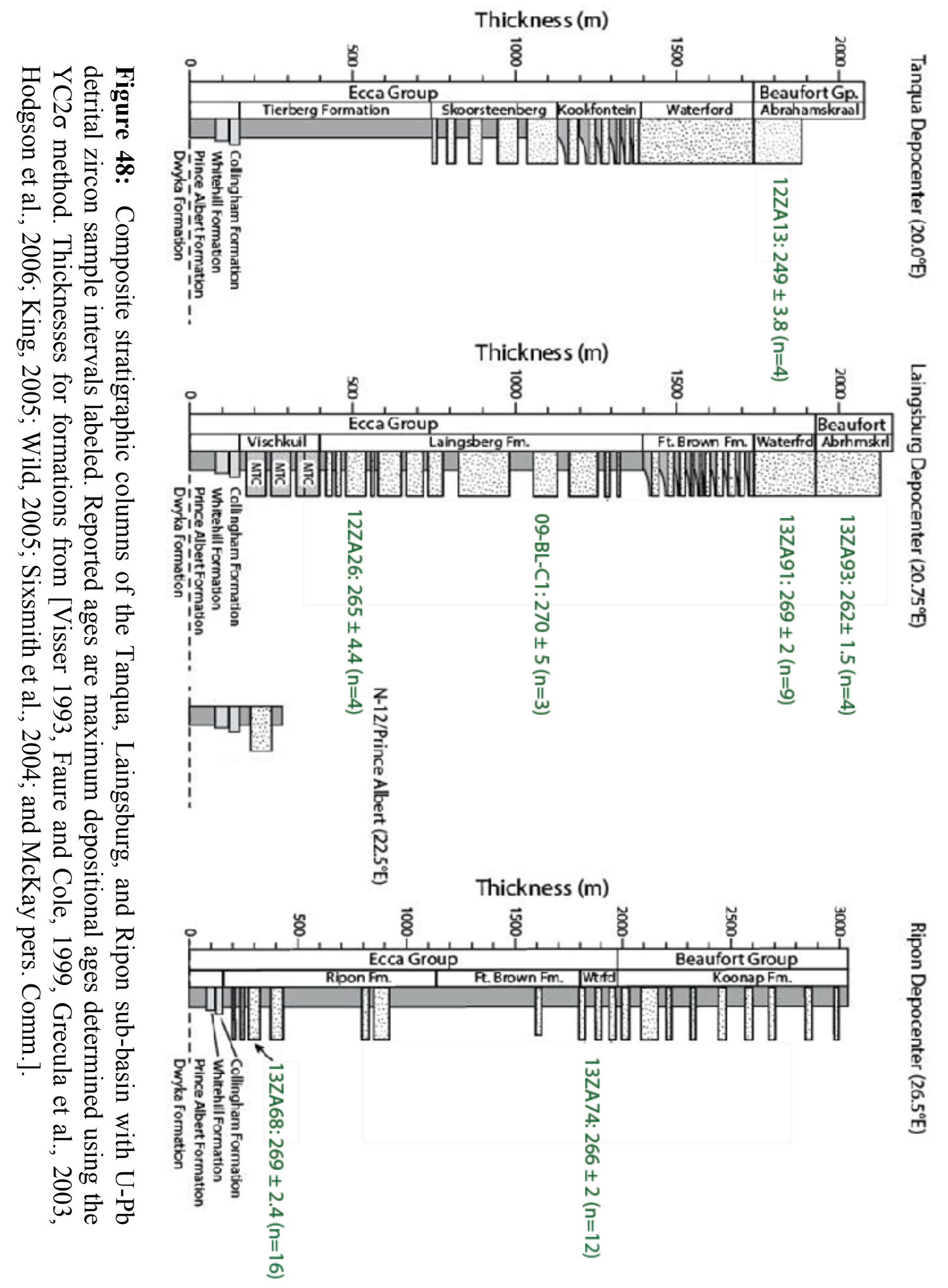




\subsection{Tanqua Sub-basin Sample Overview}

One U-Pb detrital zircon sample was collected from the Wuchiapingian Waterford Formation in the Tanqua sub-basin (12ZA13). Prominent age populations are present at 270 $\mathrm{Ma}$ and $430 \mathrm{Ma}$ whereas minor populations are present at $247 \mathrm{Ma}, 350 \mathrm{Ma}$, and $1010 \mathrm{Ma}$ (Fig. 21). Maximum depositional ages for sample 12ZA13 range from 245 to 249 Ma (Table 3). The majority of grains are Permian in age (258 to $298 \mathrm{Ma}$ ) and form a $270 \mathrm{Ma}$ age population, whereas late Carboniferous to Ordovician grains form the $430 \mathrm{Ma}$ age population (Fig. 45). Age populations present within sample 12ZA13 form similar age populations to the Waterford Formation in the Laingsburg and Ripon sub-basins but, based on the K-S test results, are only $6.1 \%$ and $22.8 \%$ similar. (Fig. $44 \&$ Table 2 ). This is likely caused by the Triassic age population present in the Waterford Formation in the Tanqua sub-basin that is absent in the Waterford Formation in the Laingsburg and Ripon sub-basin.

\subsection{Laingsburg Sub-basin Sample Overview}

Four U-Pb detrital zircon samples were taken from the Roadian Laingsburg Formation (12ZA26 and 09-BL-C1), Capitanian Waterford Formation (13ZA91) and Wuchiapingian Beaufort Group (13ZA93) in the Laingsburg sub-basin. All four sample display similar age populations and are comparable to age populations of samples within the Tanqua and Ripon sub-basins (Fig. 44). The maximum depositional age of the Waterford Formation in the Laingsburg sub-basin is approximately 20 Ma older than the Waterford Formation in the Tanqua sub-basin (Fig. $48 \&$ Table 3). The prominent Permian population is present in all four samples, however, it does not make up the majority of the grains in samples 09- BL-C1 and 13ZA93 (Fig. 45). Each sample also contains a Devonian to Neoproterozoic population. All samples in the Laingsburg sub-basin with the exception of sample 12ZA26 contain a minor 
(570 to $1240 \mathrm{Ma}$ ) Neoproterozoic to Mesoproterozoic population.

K-S Test results for samples within the Laingsburg sub-basin reveal several statistical similarities and differences when compared to samples from the Tanqua and Ripon sub-basins. Results from the K-S Test reveals p-values ranging from 30\% to $98.9 \%$ similar to Ripon subbasin samples (Table 2). When comparing the Laingsburg sub-basin samples to the Waterford Formation sample (12ZA13) in the Tanqua sub-basin, the only significantly similar samples are samples 12ZA93 and 12ZA26 of the Beaufort Group and Laingsburg Formation (79\% and $92.8 \%$, respectively), with samples 13ZA91 and 09-BL-C1 of the Waterford and Laingsburg Formations yielding low p-values ranging from $6 \%$ to $8 \%$.

\subsection{Ripon Sub-basin Sample Overview}

Two detrital zircon samples were taken from the Roadian Ripon Formation (13ZA68) and Wuchiapingian Waterford Formation (13ZA74) in the Ripon sub-basin. Both samples display similar age populations to samples within the Tanqua and Laingsburg sub-basins with varying amounts of grains in each population (Fig. 44). Maximum depositional ages of correlative units are slightly older in the Ripon sub-basin compared to the Tanqua sub-basin (Fig. 48 \& Table 3). Samples 13ZA68 and 13ZA74 contain a prominent Permian population (263 to $299 \mathrm{Ma}$ ) and makes up the majority of the grains within both samples (Fig. 45). These samples also contain a minor Carboniferous to Neoproterozoic (309 to $955 \mathrm{Ma}$ ) population. Sample 13ZA74 contains a minor Neoproterozoic to Mesoproterozoic (542 to $1325 \mathrm{Ma}$ ) population as well whereas 13ZA68 contains only single grains greater than $700 \mathrm{Ma}$ with no prominent age population (Fig. $39 \& 42$ ).

K-S test results for samples within the Ripon sub-basin reveal several statistical similarities and differences when compared to samples from the Tanqua and Laingsburg 
Formation. Results from the K-S test reveals p-values ranging from $30.5 \%$ to $98.9 \%$ similar when comparing sample 13ZA68 (Ripon Formation) to all Laingsburg sub-basin samples. Sample 13ZA74 (Waterford Formation) contains p-values ranging from $33.8 \%$ to $96.7 \%$ similar to all Laingsburg sub-basin samples. Both Ripon sub-basin samples are only slightly similar to the Waterford Formation sample in the Tanqua sub-basin with p-values of $15.5 \%$ (13ZA68) and 28.8\% (13ZA74).

\subsection{Permo-Triassic Karoo Sandstone Composition}

The point counting results from 18 thin-sections of 18 separate sandstone samples from the Tanqua, Laingsburg, and Ripon sub-basin yielded modal framework grain compositions that include lithic arkose and feldspathic litharenite. Framework grains included monocrystalline quartz (undulose and non- undulose), polycrystalline quartz, plagioclase feldspar (untwinned and twinned), orthoclase feldspar, sedimentary lithic fragments (chert and siltstone), volcanic lithic fragments (felsititc, lathwork and volcanic ash fragments), and metamorphic lithic fragments (phyllite and gneiss). Samples appear to be evenly mixed between lithic arkose and feldspathic litharenite compositions [Folk, 1980] (Fig. 50, 51, 52, and 53). A total of eight samples are classified as lithic arkose and seven samples are classified as feldspathic litharenite and three samples fall on the border between lithic arkose and feldspathic litharenite. 
A.

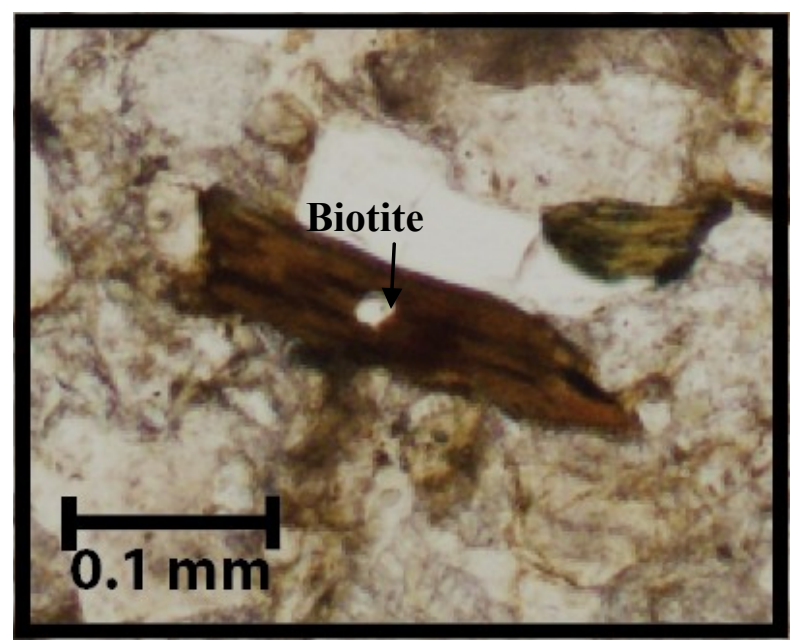

C.

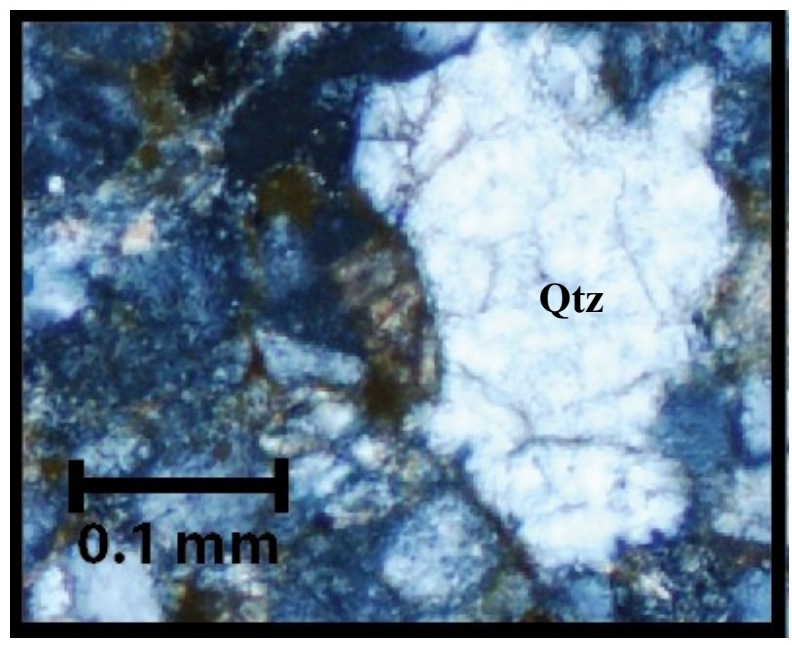

E.

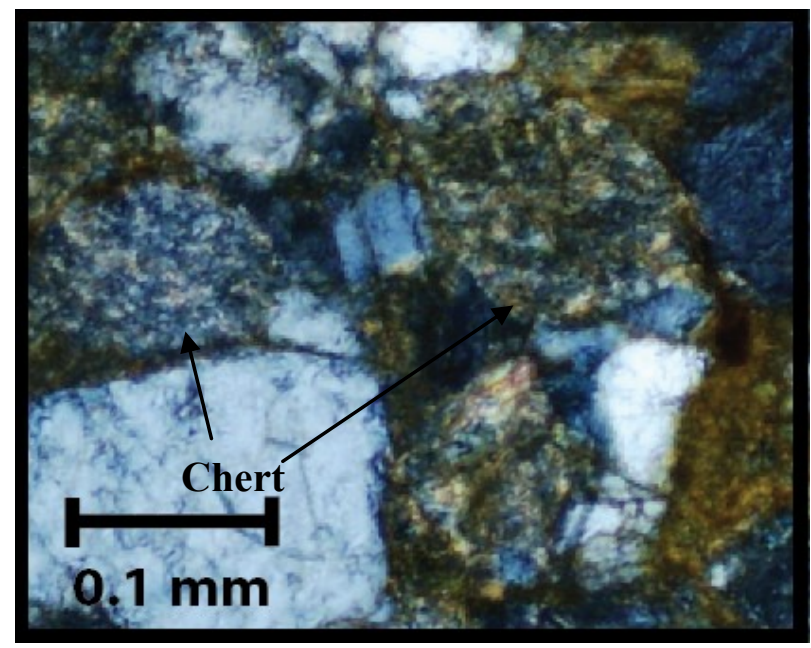

B.

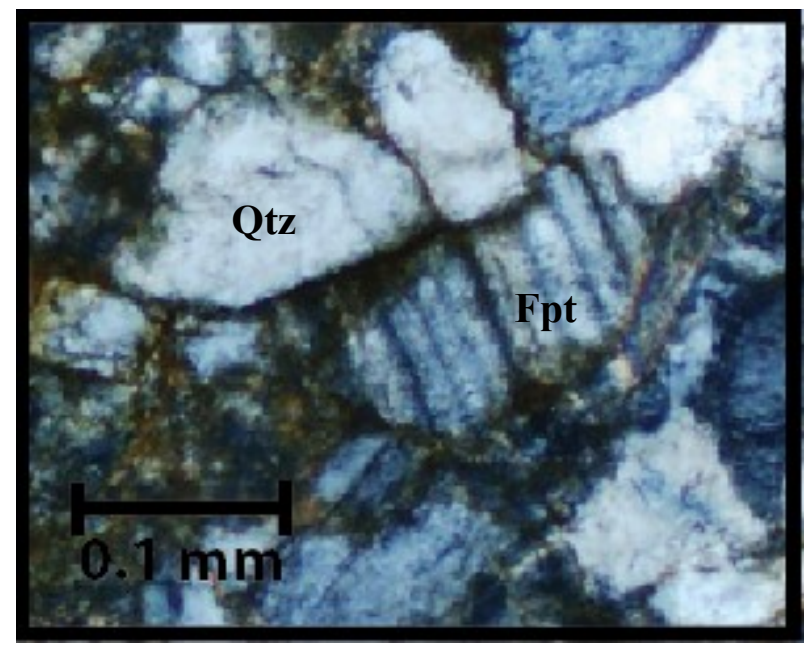

D.
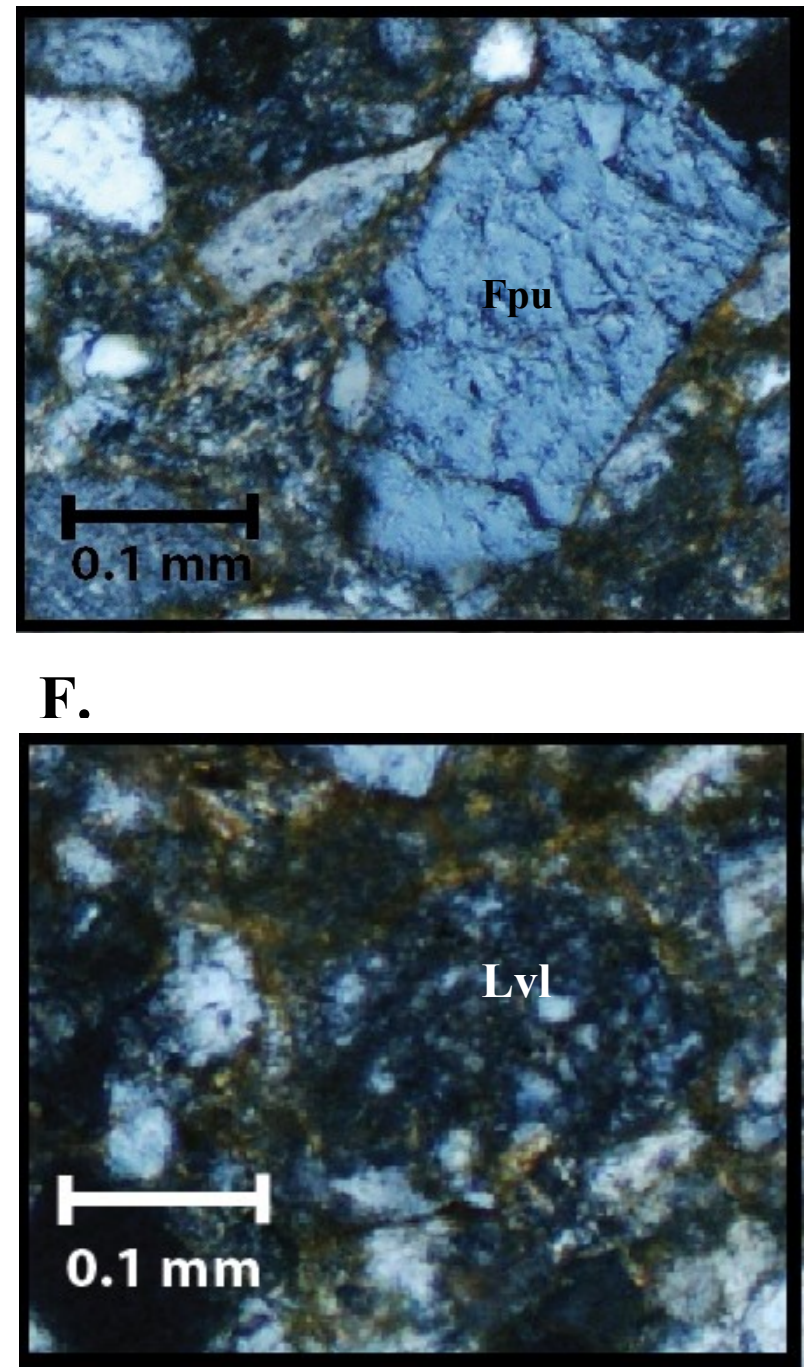

Figure 49: Framework grains in thin-section. A) Biotite grain in plane polarized light (PPL) from sample 12ZA13. B) Quartz and twinned plagioclase feldspar in cross polarized light (XPL) from sample 09-BL-C1. C) Monocrystalline quarts grain in XPL from sample 13ZA91. D) Untwinned plagioclase feldspar in XPL from sample 13ZA68. E) Chert grains in XPL from sample 09-BL-C1. F) Lathwork volcanic lithic fragment in XPL from sample 13ZA68. 


\subsubsection{Tanqua Sub-basin}

One sample was collected and analyzed from the Wuchiapingina Waterford Formation (12ZA13) in the Tanqua sub-basin and plots within the lithic arkose field (Fig. 50). The dominant framework grain type within this sample is monocrystalline quartz which accounts for $50.25 \%$ of grains (Fig. 54). The next most dominant framework grain type is feldspar which makes up approximately $22 \%$ of grains. This sample contains slightly more untwinned plagioclase feldspar (12\%) than twinned plagioclase feldspar (9\%) whereas orthoclase feldspar only accounts for approximately $1 \%$ of grains (Fig. 54). Lithic abundance (20.5) within the sample is slightly less than total feldspar grains. Sedimentary lithics are the most abundant lithic type (18.5\%) and are composed primarily of chert and siltstone fragments. Volcanic and metamorphic lithics only account for approximately $1 \%$ of total grains and are characterized by lathwork and volcanic ash fragments and gneiss, phyllite, and quartzite metamorphic grains.

Overall grain size ranges from fine to medium and grain shape ranges from sub-rounded to angular, with varying degrees of sphericity ranging from low to moderate with rare highly spherical grains. Sandstones are well to moderately sorted with no apparent bedding present in any of the samples. Framework grain contacts are sutured in some areas and cements in these three samples mainly quartz. No pore space is present in any of the samples.

The Waterford Formation in the Laingsburg sub-basin is comparable to the Waterford Formation in the Laingsburg and Ripon sub-basins with only slight variations in framework grain modal abundances. 


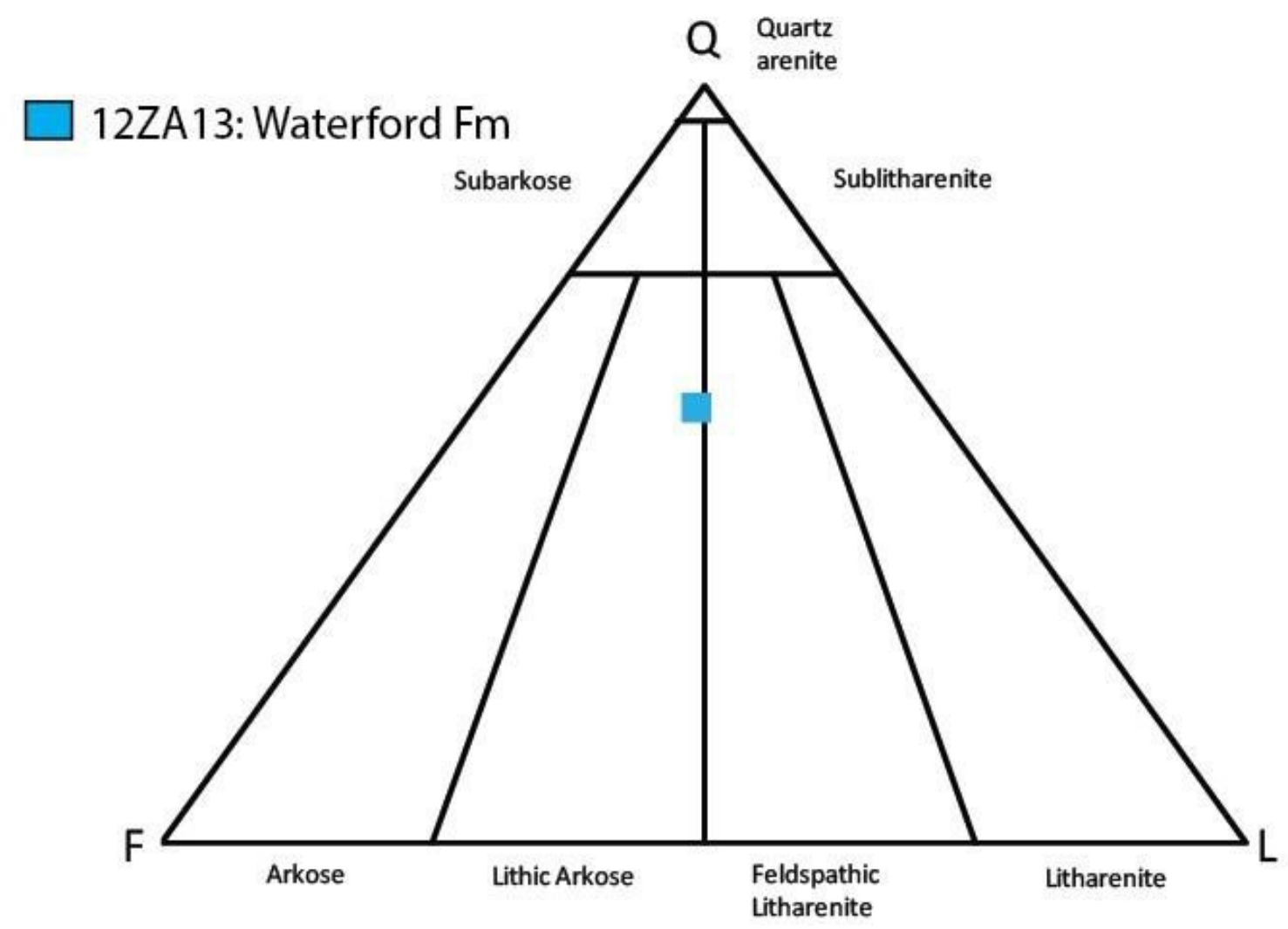

Figure 50: Q-F-L diagram for one sandstone sample within the Tanqua sub-basin. The sample plots within the lithic arkose field. Diagram fields after Folk (1980).

\subsubsection{Laingsburg Sub-basin}

A total of 11 sandstone samples collected from the Laingsburg and Waterford Formations and Beaufort Group in the Laingsburg sub-basin were analyzed. Samples 09-BL-E1(Roadian Laingsburg Formation), 13ZA86 (Roadian Laingsburg Formation), 13ZA91 (Capitanian Waterford Formation), 13ZA90 (Wuchiapingian Beaufort Group), and 13ZA92 (Wuchiapingian Beaufort Group) are classified as lithic arkose sandstones and samples 12ZA26, 09-BL-A1, 09BL-C1and 13ZA88 from the Roadian Laingsburg Formation are classified as feldspathic litharenite sandstones and samples 13ZA87 (Roadian Laingsburg Formation) and 13ZA93 (Wuchiapingian Beaufort Group) lie on the border between the two fields (Fig. 51 \& 52). The 
dominant framework grain type in lithic arkose samples is monocrystalline quartz which ranges from $35 \%$ to $40.5 \%$ of grains (Fig. 54). Polycrystalline quartz grains are less significant, only accounting for $3 \%$ to $4.3 \%$ of all grains. The next dominant framework grain type is plagioclase feldspar which ranges from $23.3 \%$ to $36.5 \%$ of grains whereas orthoclase feldspar grains are rare (0.5-1.5\%) (Fig. 54). All lithic arkose samples appear to contain slightly more un- twinned plagioclase feldspar (13.5-19.8\%) than twined plagioclase feldspar (10.8-13.5\%) with the exception of sample 13ZA90 ( $20 \%$ twinned and 13.5\% untwinned). Lastly, lithic framework grains are slightly less significant than feldspar grains in each sample. Total lithics within the five lithic arkose samples ranges from $20 \%$ to $29.3 \%$ of grains. Sedimentary lithics make up the majority of the total lithics ranging from $17.8 \%$ to $22 \%$ of grains and $69 \%$ to $88 \%$ of lithic grains and consist mainly of chert and siltstone fragments (Fig. 54). Volcanic lithics are less common ranging from $2 \%$ to $7.8 \%$ of grains and are felsic in nature and were composed primarily of felsitic, lathwork and volcanic ash fragments. Metamorphic lithics are rare only accounting for approximately $1 \%$ of grains and are characterized by gneiss, phyllite, and quartzite grains.

Overall lithic arkose sandstone grain size ranges from fine to medium and grain shape ranges from sub-rounded to angular with varying degrees of sphericity ranging from low to moderate with rare highly spherical grains. Sandstones are well to moderately sorted with no apparent bedding present in any of the samples. Framework grain contacts are sutured in some areas and cements in these three samples are mainly quartz. No pore space is present in any of the samples.

The dominant framework grain type in feldspathic litharenite samples are lithic framework grains. Total lithics within the three lithic arkose samples ranges from $29 \%$ to $34.3 \%$ of grains. Sedimentary lithics make up the majority of the total lithics ranging from $23 \%$ to 
$26.8 \%$ of grains and $72 \%$ to $92 \%$ of lithic grains (Fig. 54 ). Volcanic lithics are less common ranging from $1.5 \%$ to $8.5 \%$ of grains and are felsic in nature. Metamorphic lithics are rare only accounting for approximately zero to $2.3 \%$ of grains. Lastly, feldspar framework grains are slightly less abundant than lithic grains in each sample. Plagioclase feldspar grains range from $23.5 \%$ to $28.5 \%$ of grains whereas orthoclase feldspar grains are rare and only account for approximately $1 \%$ of grains (Fig. 54). All feldspathic litharenite samples appear to contain slightly more untwinned plagioclase feldspar (5-14.5\% of grains) than twined plagioclase feldspar (6-8\% of grains).

Overall feldspathic litharenite sandstone grain size ranges from fine to medium and grain shape ranges from sub-rounded to angular with varying degrees of sphericity ranging from low to moderate with rare highly spherical grains. Sandstones are well to moderately sorted with no apparent bedding present in any of the samples. Framework grain contacts are sutured in some areas and cements in these three samples are mainly quartz. No pore space is present in any of the samples.

Samples 13ZA87 and 13ZA93, which lie on the border between the lithic arkose and feldspathic litharenite fields, have uniform compositions with slightly varying amounts of quartz. The dominant framework grain type in both samples is monocrystalline quartz (13ZA87: $38.8 \%$; 13ZA93: 44\%). Sample 13ZA87 has equal amounts of feldspar and lithics (feldspar: 28.8\%; lithics: $28.3 \%$ ) as well as 13ZA93 (feldspar: 23.3\%; lithics: $23.5 \%$ ). Both samples contain slightly more untwinned plagioclase feldspar (13ZA87: 17\%; 13ZA93: 14.5\%) than twinned plagioclase feldspar (13ZA87: 11.8\%; 13ZA93: 8\%). Orthoclase feldspar in both samples only accounts for approximately $1 \%$ of grains. Sedimentary lithic grains are the dominant lithic type in both samples (13ZA87: 22.5\%; 13ZA93: 20.8\%) whereas volcanic lithics are much less 
abundant (13ZA87: 4.5\%; 13ZA93: 2.8\%). Metamorphic lithics in both samples only accounts for $1.3 \%$ of grains of less. Petrographic qualities of these two samples are consistent with other samples within the Laingsburg sub-basin.

Temporal variations in the amount of lithics were present in the Laingsburg sub-basin samples. Overall, it appears that total lithic fragments increase (2-11\%) down section from the Beaufort Group to the Laingsburg Formation. No temporal trends in feldspar or quartz framework grains appear in the Laingsburg sub-basin samples.

\section{Explanation}

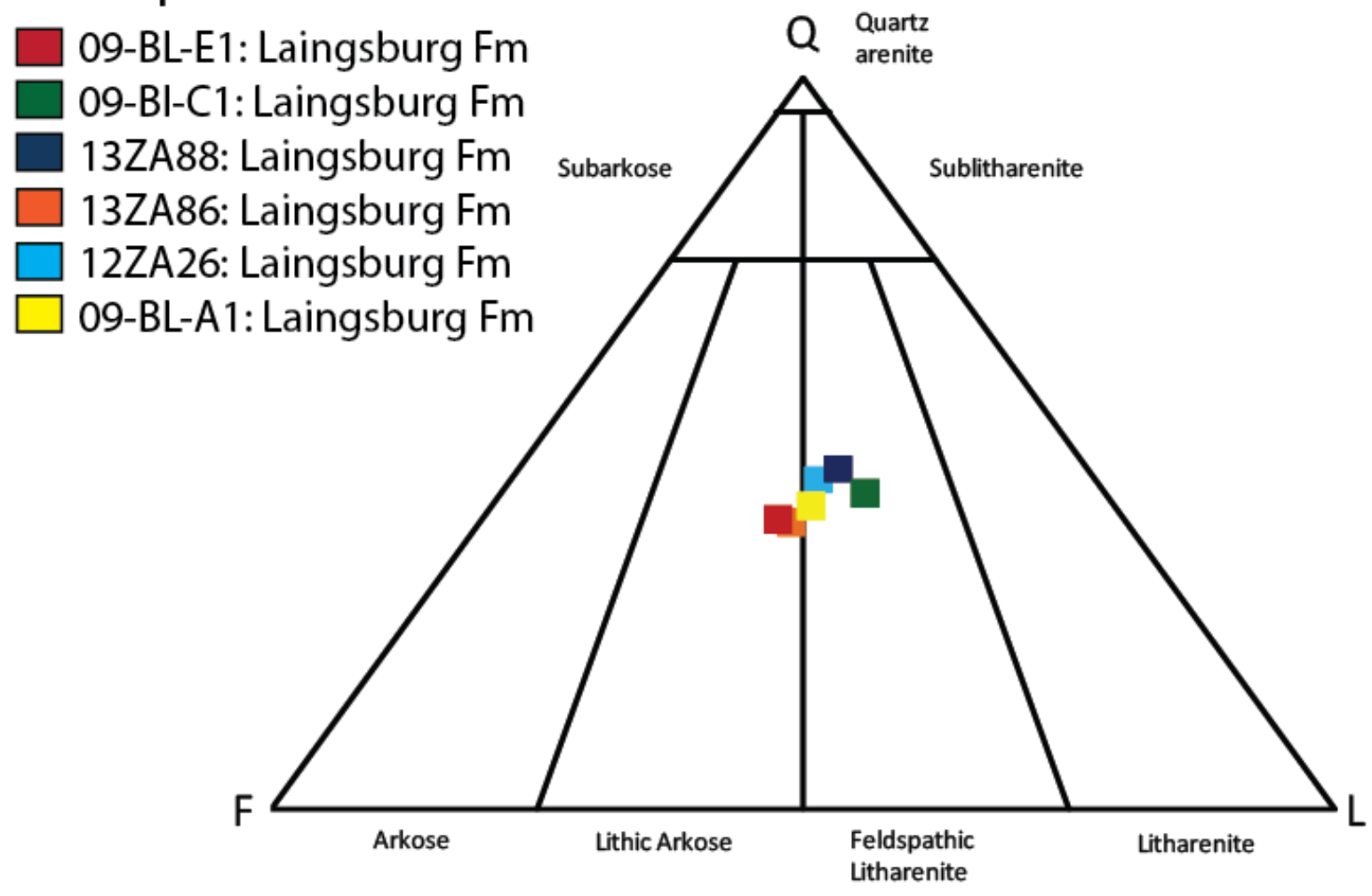

Figure 51: Q-F-L diagram for six sandstone samples within the Laingsburg sub- basin. Samples plot within the lithic arkose and feldspathic litharenite fields. Diagram fields after Folk (1980). 


\section{Explanation}

$\square$ 13ZA92: Beaufort Grp

$\square$ 13ZA93: Beafort Grp

$\square$ 13ZA90: Beaufort Grp

13ZA91: Waterford $\mathrm{Fm}$

$\square$ 13ZA87: Waterford Fm

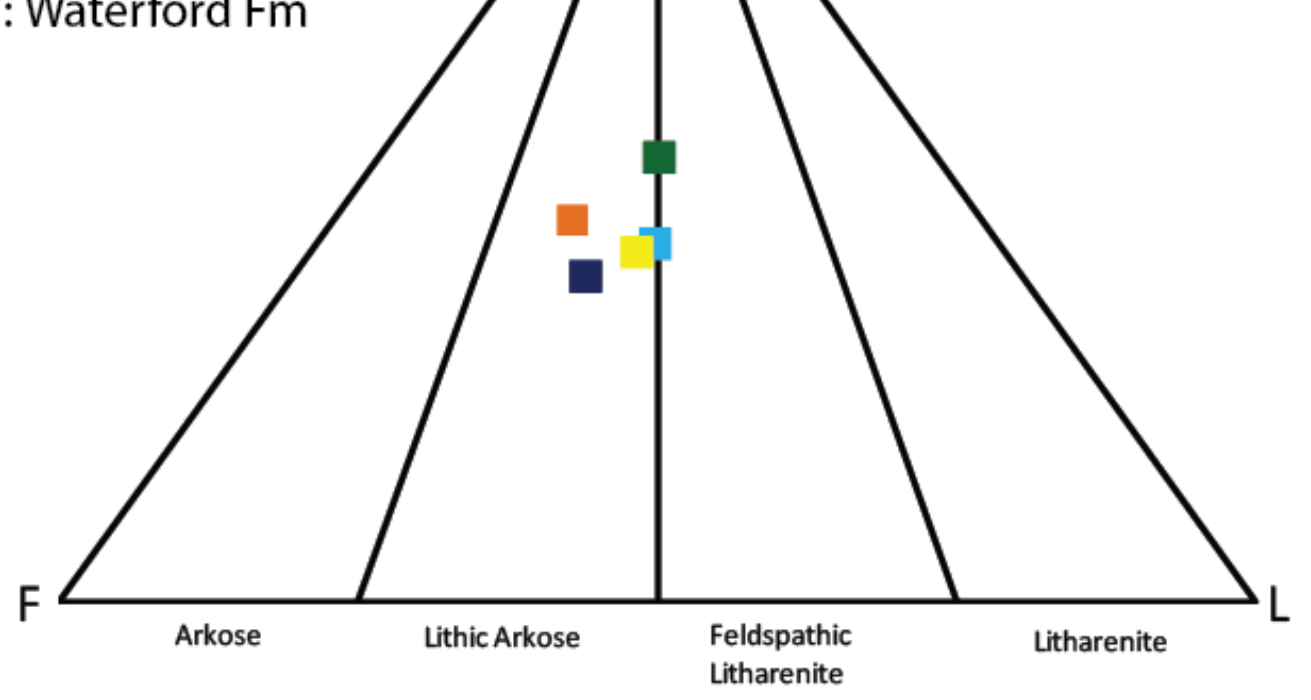

Figure 52: Q-F-L diagram for five sandstone samples within the Laingsburg sub-basin. Samples plot within the lithic arkose field or lie on the border between the lithic arkose and feldspathic litharenite fields. Diagram fields after Folk (1980). 


\subsubsection{Ripon Sub-basin}

A total of six thin-section samples from the Ripon sub-basin were analyzed using the Gazzi-Dickinson point counting method. Sandstone samples from the Ripon, Waterford, and Koonap Formations and Beaufort Group in the Ripon sub-basin are similar in appearance and composition. Samples 13ZA72 (Wuchiapingian Beaufort Group), 13ZA74 (Capitanian Waterford Formation), and 13ZA78 (Roadian Ripon Formation) are classified as lithic arkose sandstones and samples 13ZA73 (Wuchiapingian Koonap Formation), 13ZA71 (Capitanian Waterford Formation), and 13ZA68 (Roadian Ripon Formation) are classified as feldspathic litharenite sandstones (Fig. 53). The dominant framework grain in lithic arkose samples is monocrystalline quartz which ranges from $38.5 \%$ to $51.5 \%$ of grains (Fig. 54). Polycrystalline quartz grains are less significant, only accounting for $3.5 \%$ to $7.5 \%$ of all grains. The next dominant framework grain type is plagioclase feldspar which ranges from $26.5 \%$ to $31.3 \%$ of grains whereas orthoclase feldspar grains are rare (0.5-2\%) (Fig. 54). All lithic arkose samples appear to contain slightly more twinned plagioclase feldspar (13.75-19.5\%) than untwinned plagioclase feldspar (10.75-13.5\%). Lastly, lithic framework grains are slightly less abundant than feldspar. Total lithic abundances within the three lithic arkose samples ranges from $14.5 \%$ to $24 \%$ of grains. Sedimentary lithics make up the majority of the total lithics ranging from $9.25 \%$ to $17.75 \%$ of grains and $63 \%$ to $75 \%$ of lithic grains (Fig. 54 ). Sedimentary lithics were primarily chert and siltstone fragments. Volcanic lithics are less common ranging from $4.75 \%$ to $7.5 \%$ of grains and were composed primarily of felsitic, lathwork and volcanic ash fragments. Metamorphic lithics were rare only accounting for approximately $1 \%$ of grains and are characterized by gneiss, phyllite, and quartzite grains.

Overall lithic arkose sandstone grain size ranges from fine to medium and grain shape 
ranges from sub-rounded to angular with varying degrees of sphericity ranging from low to moderate with rare highly spherical grains. Sandstones well to moderately sorted with no apparent bedding present in any of the samples. Framework grain contacts are sutured in some areas and cements in these three samples are mainly quartz. No pore space is present in any of the samples.

The dominant framework grain type in the three feldspathic litharenite samples is monocrystalline quartz which ranges from $39.75 \%$ to $49.75 \%$ of grains (Fig. 53 \& 54). Polycrystalline quartz grains are less abundant, only accounting for $4 \%$ to $8.75 \%$ of all grains. The next dominant framework grain in feldspathic litharenite samples are lithic framework grains. Total lithics within the three lithic arkose samples ranges from $24 \%$ to $35.75 \%$ of grains. Sedimentary lithics make up the majority of the total lithics ranging from $16.25 \%$ to $31.25 \%$ of grains and $68 \%$ to $87 \%$ of lithic grains (Fig. 54 ). Volcanic lithics are relatively less common ranging from $2.75 \%$ to $6.75 \%$ of grains and are felsic in nature. Metamorphic lithics are rare only accounting for approximately $1 \%$ of grains. Lastly, feldspar framework grains are slightly less significant than lithic grains in each sample. Plagioclase feldspar grains range from $26.5 \%$ to $31.25 \%$ of grains whereas orthoclase feldspar grains are rare and only account for approximately $1 \%$ of grains (Fig. 54). All feldspathic litharenite samples appear to contain slightly more untwinned plagioclase feldspar ( $8.75 \%$ to $13.25 \%$ of grains) than twined plagioclase feldspar (6\% to $8 \%$ of grains).

Overall feldspathic litharenite sandstone grain size ranges from fine to medium and grain shape ranges from sub-rounded to angular with varying degrees of sphericity ranging from low to moderate with rare highly spherical grains. Sandstones are well to moderately sorted with no apparent bedding present in any of the samples. Framework grain contacts are sutured in some 
areas and cements in these three samples are mainly quartz. No pore space is present in any of the samples.

Temporal variations in the amount of quartz were present in the Ripon sub-basin samples. Overall, it appears that quartz increases (1-12\%) up section from the Ripon Formation to the Beaufort Group. No temporal trends in feldspar or lithic framework grains appear in the Ripon sub-basin samples.

\section{Explanation}

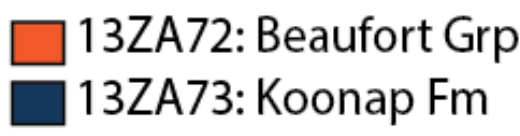

$\square$ 13ZA71: Waterford Fm

$\square$ 13ZA74: Waterford Fm

$\square$ 13ZA78: Ripon Formation

$\square$ 13ZA68: Ripon Formation

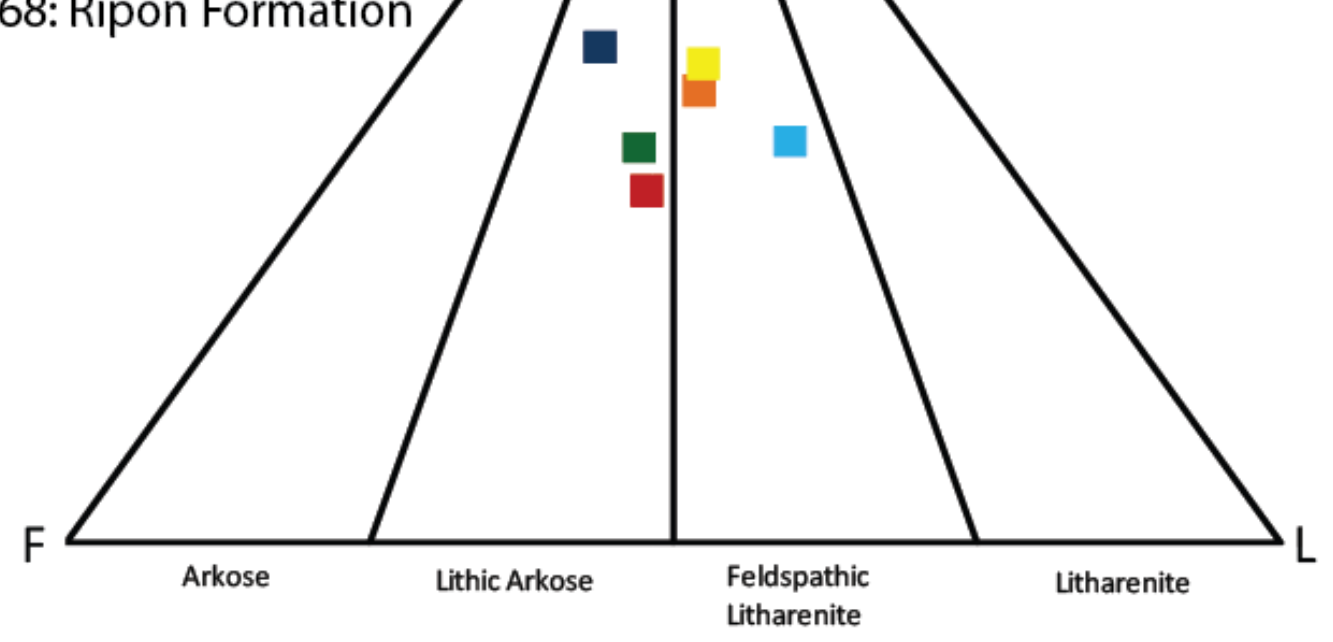

Figure 53: Q-F-L diagram for six sandstone samples within the Ripon sub-basin. Samples plot within the lithic arkose and feldspathic litharenite fields. Diagram fields after Folk (1980). 
12ZA13: Waterford Fm.

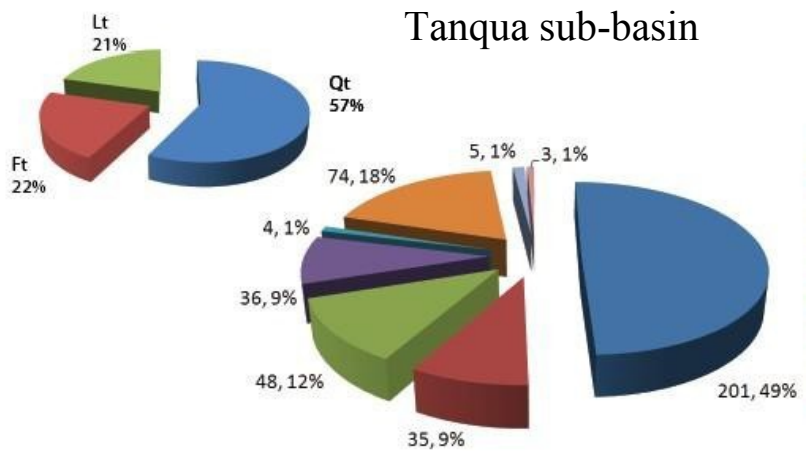

13ZA71: Waterford Fm.

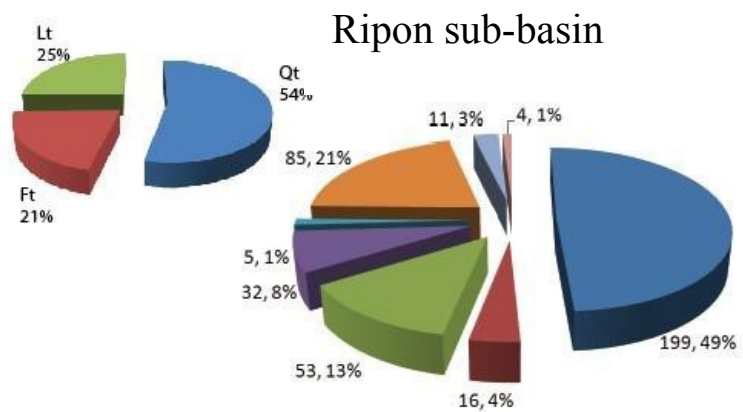

13ZA73: Koonap Fm.
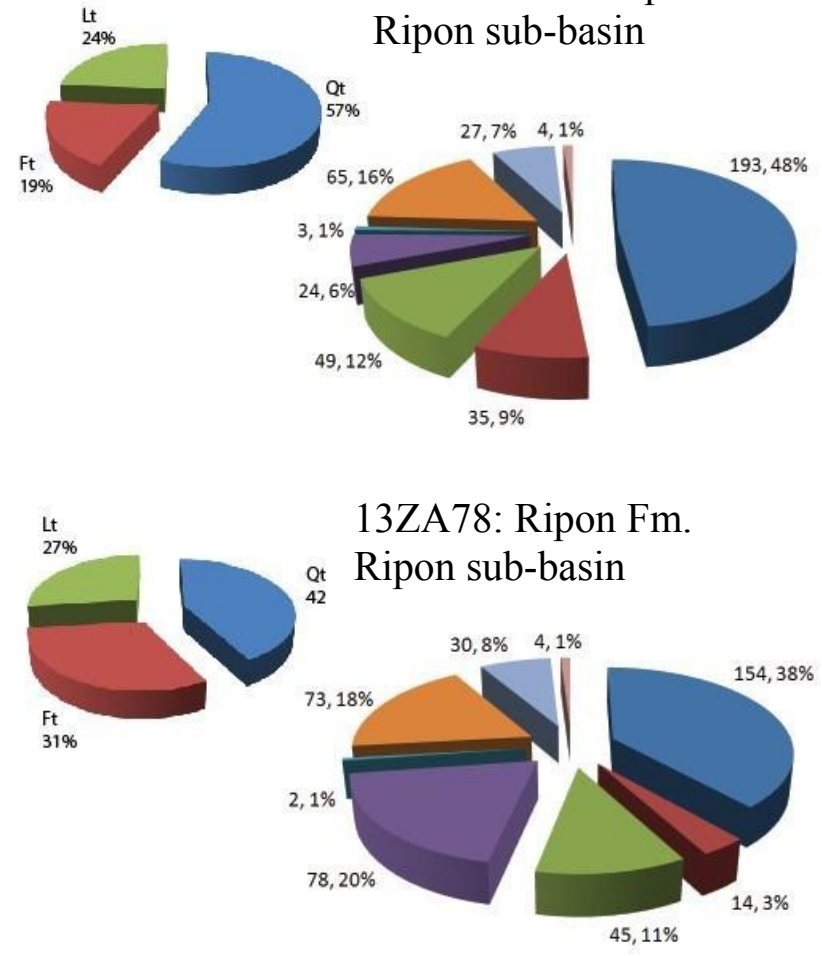

13ZA86: Laingsburg Fm.

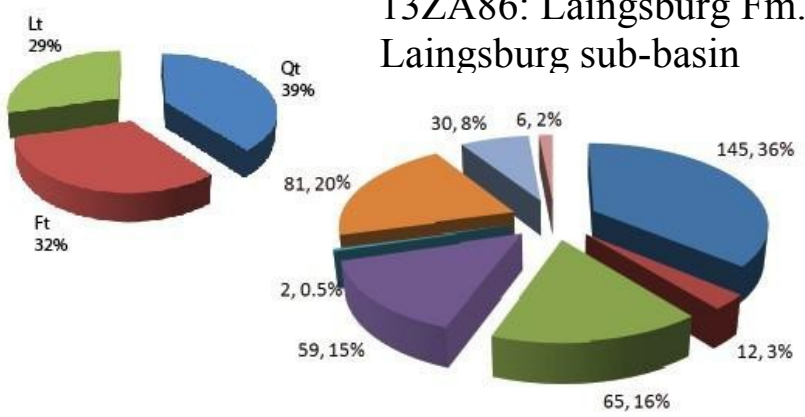

13ZA68: Ripon Fm.

Ripon sub-basin
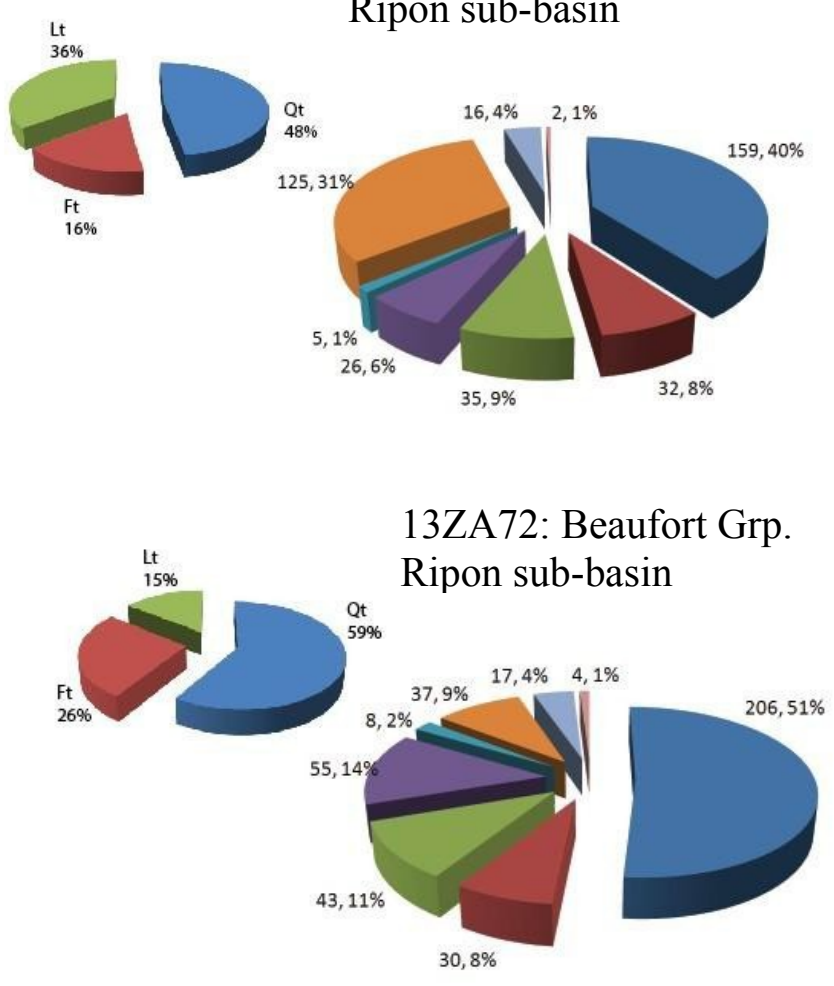

13ZA74: Waterford Fm.

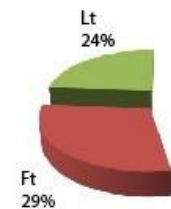

Ripon sub-basin

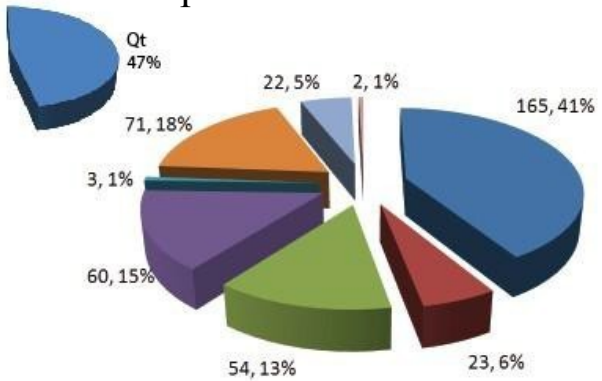

12ZA26: Laingsburg Fm. Laingsburg sub-basin
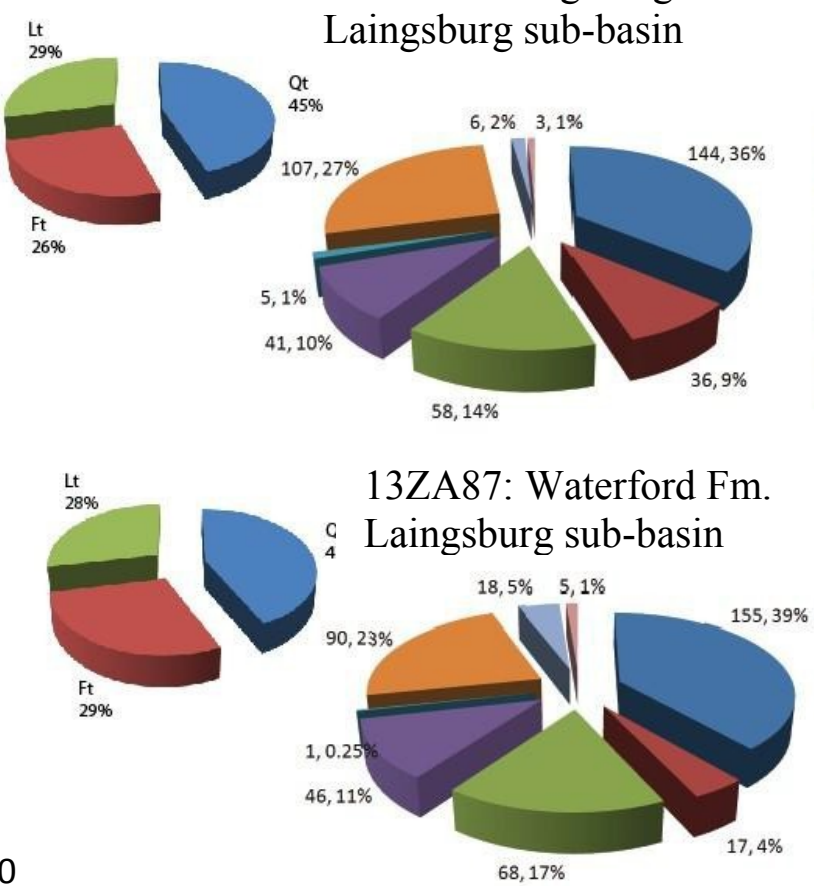

Explanation Qm - Op - Fpu - Fpt E $\mathrm{Fk}$ Es ㄴ. $\mathrm{LV}$ Em 

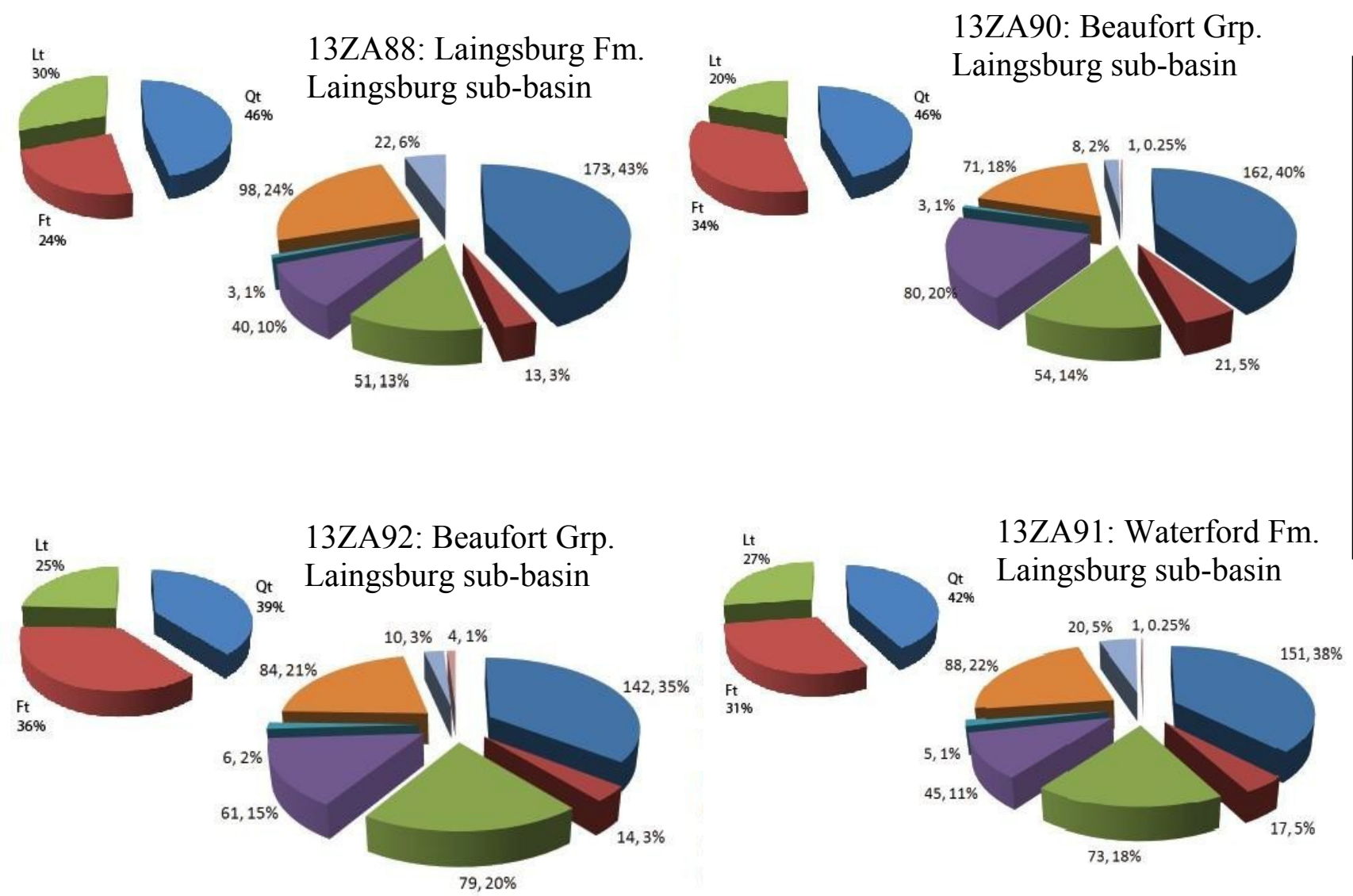

\begin{tabular}{|c|}
\hline Explanation \\
$=\mathrm{Qm}$ \\
$=\mathrm{Qp}$ \\
$=\mathrm{Fpu}$ \\
$=\mathrm{Fpt}$ \\
$=\mathrm{Fk}$ \\
$=\mathrm{Ls}$ \\
$=\mathrm{Lv}$ \\
$=\mathrm{Lm}$ \\
\hline
\end{tabular}
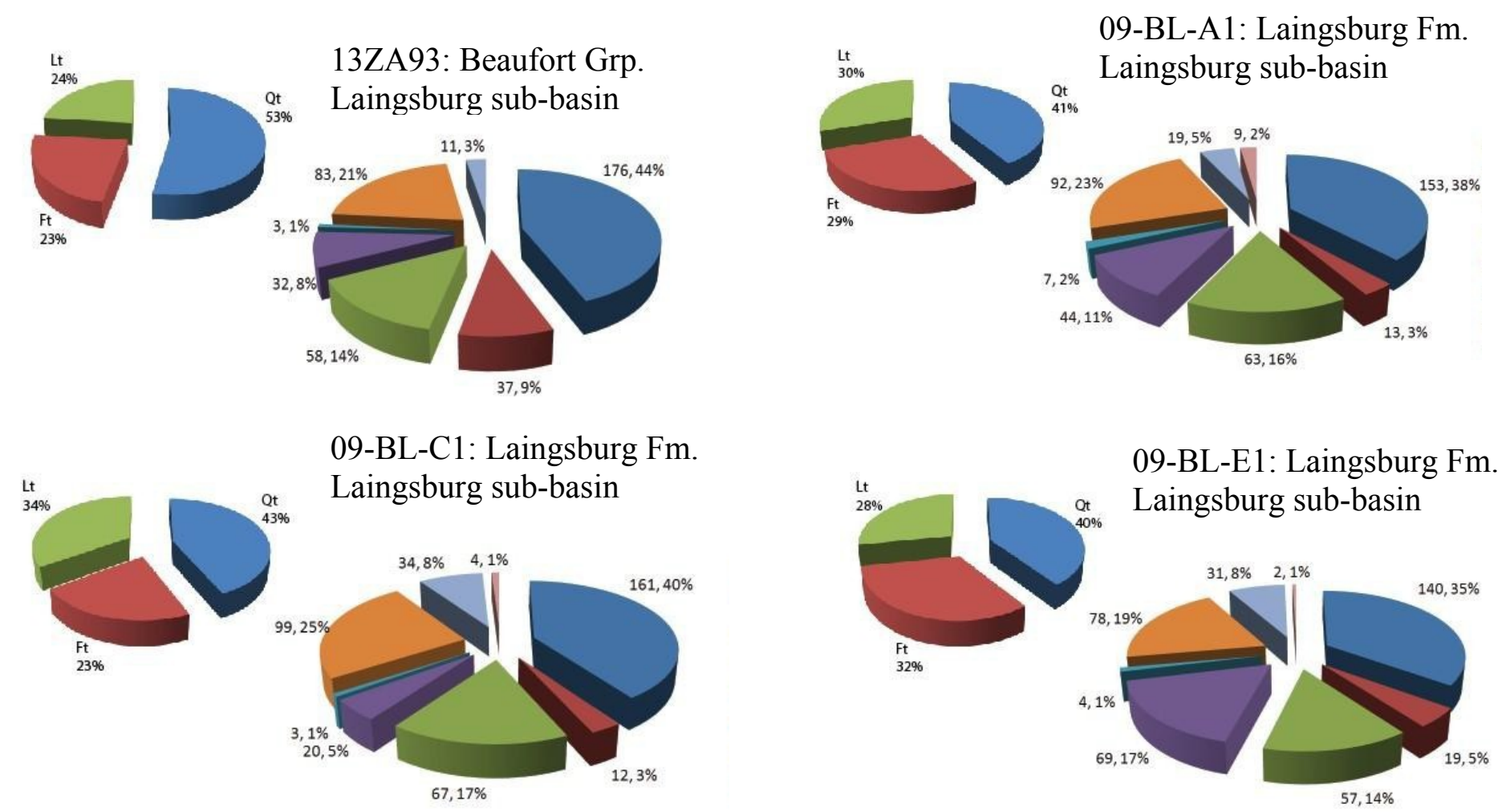

Figure 54: Mineralogical abundances (number of grains, percentage of total grains) of all sandstone samples collected within the Karoo basin. Qm= monocrystalline quartz, Qp= polycrystalline quartz, $\mathrm{Fpu}=$ untwinned plagioclase feldspar, $\mathrm{Fpt}=$ twinned plagioclase feldspar, $F k=$ orthoclase feldspar, $L s=$ sedimentary lithics, $L v=$ volcanic lithics, $\mathrm{Lm}=$ metamorphic lithics. 


\subsection{Heavy Mineral Analysis}

Heavy minerals were counted for 15 samples collected throughout the Karoo basin. The results of heavy mineral analysis revealed relatively uniform mineral abundances within the collected samples (Fig. 55). Note that the remaining zircon separates were mixed back in to the heavy mineral fraction after zircons were mounted for $\mathrm{U}-\mathrm{Pb}$ dating.

\subsubsection{Tanqua Sub-basin Heavy Minerals Sample}

Only one sample was collected from the Tanqua sub-basin (12ZA13: Waterford Formation) for heavy mineral analysis. The Waterford Formation of the Tanqua sub-basin contained nearly equal amounts of neosilicates and phyllosilicates with less amounts of other miscellaneous accessory minerals. Sample 12ZA13 contained abundant amounts of zircon (25\%), muscovite (16.7\%), and biotite (16.7\%) with lesser amounts of sphene, topaz, andalusite, chlorite, and other miscellaneous accessory minerals.

\subsubsection{Laingsburg Sub-basin Heavy Minerals Samples}

The nine Laingsburg sub-basin samples are relatively similar with respect to neosilicates (topaz, zircon, sphene, and andalusite), phyllosilicates (muscovite, biotite, and chlorite) and other miscellaneous accessory mineral (rutile, pyroxene: augite; calcicamphibole: tremolite, amphibole, and hornblende; epidote: axinite, clinozoisite, and tourmaline; and phosphates: xenotime, monazite, apatite). Total neosilicates are slightly variable ranging from $36 \%$ to $48 \%$ of all counted grains (topaz: $0-10 \%$; zircon: $26-44 \%$; and sphene: $0-8 \%$; andalusite: $0-2 \%$ of all grains) (Fig. 55). Andalusite grains are only present in sample 09-BL-E1. Phyllosilicate grain abundances are relatively uniform throughout all Laingsburg sub-basin samples ranging from $37 \%$ to $50 \%$ of all counted grains with muscovite 
(14-20\%) and biotite (16-27\%) being the most abundant phases present along with lesser abundances of chlorite (2-6\%).

Other minor mineral phases are much less abundant and range from $12 \%$ to $20 \%$ of all counted grains and include rutile (0-6\%), pyroxene (0-2\%), calcic-amphibole: $(2-8 \%)$ epidote (0- 8\%), and phosphates (2-6\%) (Fig. 55). Rutile grains are present in all samples with the exception of samples 13ZA93 and 09-BL-E1. Epidote grains are also absent in samples 13ZA91 and 09-BL-A1.

\subsubsection{Ripon Sub-basin Heavy Minerals Samples}

The five Ripon sub-basin samples are relatively similar with respect to neosilicates (topaz, zircon, sphene, and andalusite), phyllosilicates (muscovite, biotite, and chlorite) and other miscellaneous accessory mineral (rutile, pyroxene: augite; calcic- amphibole: tremolite, amphibole, and hornblende; epidote: axinite, clinozoisite, and tourmaline; and phosphates: xenotime, monazite, apatite). Total neosilicates range from $40 \%$ to $47 \%$ of all counted grains (topaz: 4-12\%; zircon: 24-35\%; and sphene: 2-8\%; andalusite: 0-6\% of all grains) (Fig. 55). Andalusite grains are only present in samples 13ZA68 and 13ZA73. Phyllosilicate grains abundances appear to be very uniform throughout all Ripon sub-basin samples ranging from $40 \%$ to $44 \%$ of all counted grains with muscovite (10-18\%) and biotite (22- $24 \%$ ) being the most abundant phases present along with lesser abundances of chlorite (4-8\%). Other minor mineral phases are much less abundant ranging from $10 \%$ to $17 \%$ of all counted grains and include rutile (0-4\%), calcic-amphibole (2-10\%), epidote (2-6\%), and phosphates (2-6\%). Rutile grains are absent in sample 13ZA74 and 13ZA78. Overall, Ripon Formation samples are very similar containing nearly identical neosilicate (13ZA68:40\%; 13ZA78: 40\%), phyllosilicate (13ZA68: 42\%; 13ZA78: 44\%) and minor mineral phase abundances (13ZA68: 
18\%; 13ZA78: 16\%) (Fig. 55). No apparent temporal trends in grain abundances are present in any of the Ripon sub-basin samples

\subsubsection{Evolution of Heavy Mineral Abundances}

Overall, middle Ecca Group turbidite samples are relatively similar containing 36\% to $48 \%$ neosilicate (topaz, zircon, sphene, and andalusite), $38 \%$ to $45 \%$ phyllosilicates (muscovite, biotite, and chlorite) and $12 \%$ to $20 \%$ minor mineral phases (rutile, pyroxene: augite; calcicamphibole: tremolite, amphibole, and hornblende; epidote: axinite, clinozoisite, and tourmaline; and phosphates: xenotime, monazite, apatite) (Fig. 55). Samples 12ZA26, 09-BL-A1, 13ZA86, and 13ZA88 of the Laingsburg Formation in the Laingsburg sub-basin and samples 13ZA68 and 13ZA78 of the Ripon Formation in the Ripon sub-basin are all similar with respect to all heavy mineral abundance (Fig. 55). Samples 09-BL-C1, and 09-BL-E1of the Laingsburg Formations appear to contain slightly higher amounts of neosilicates and phyllosilicates with lesser of minor mineral phases compared to other middle Ecca Group turbidites. Only two samples, 13ZA68 and 09-BL-E1, contained andalusite.

Waterford samples across the Karoo basin are somewhat variable with respect to neosilicates (topaz, zircon, sphene, and andalusite), phyllosilicates (muscovite, biotite, and chlorite) and other minor mineral phases (rutile, pyroxene: augite; calcic-amphibole: tremolite, amphibole, and hornblende; epidote: axinite, clinozoisite, and tourmaline; and phosphates: xenotime, monazite, apatite). Neosilicates grains are relatively uniform in the Tanqua (12ZA13: 37\%) and Laingsburg sub-basins (13ZA91: 36\%) whereas the Ripon sub-basin sample (13ZA74: 47\%) contains $\sim 10 \%$ more neosilicate grains. Individual neosilicate grain abundances including topaz (7\%), zircon (26\%), sphene (2\%), and andalusite (2\%) and are comparable to 
analyzed samples collected across the Karoo basin (Fig. 55).

Phyllosilicate grain abundances are variable in the Waterford Formation throughout the three sub-basins. Sample 12ZA13 contains slightly less phyllosilicate grains (37\%) than samples 13ZA74 (43\%) and 13ZA91 (50\%) (Fig. 55). Individual phyllosilicate grain abundances (12ZA13- muscovite: 17\%; biotite: 17\%; and chlorite: 4\%) are variable within the Waterford Formation (muscovite: 13-20\% biotite: 16-26\%; and chlorite: 4-6\%) but are comparable to other samples. Other minor mineral phase abundance are comparable within the Ripon (13ZA74: 10\%) and Laingsburg sub-basin (13ZA91: 14\%) but are more prevalent in the Tanqua sub-basin (12ZA13: 26\%). Sample 12ZA13 contains substantially more pyroxene $(10 \%)$ than all other samples whereas only two samples contain pyroxene grains (12ZA13 and 12ZA26). In general, minor mineral phase abundances of sample 12ZA13 are comparable to other analyzed samples. Beaufort Group samples (13ZA72, 13ZA73, 13ZA90, and 13ZA93) throughout the Laingsburg and Ripon sub-basins are also very similar with neosilicate (40$44 \%$ ), phyllosilicate (37-46 \%), and minor mineral phase (14- 19\%) abundances within $>10 \%$ difference. 


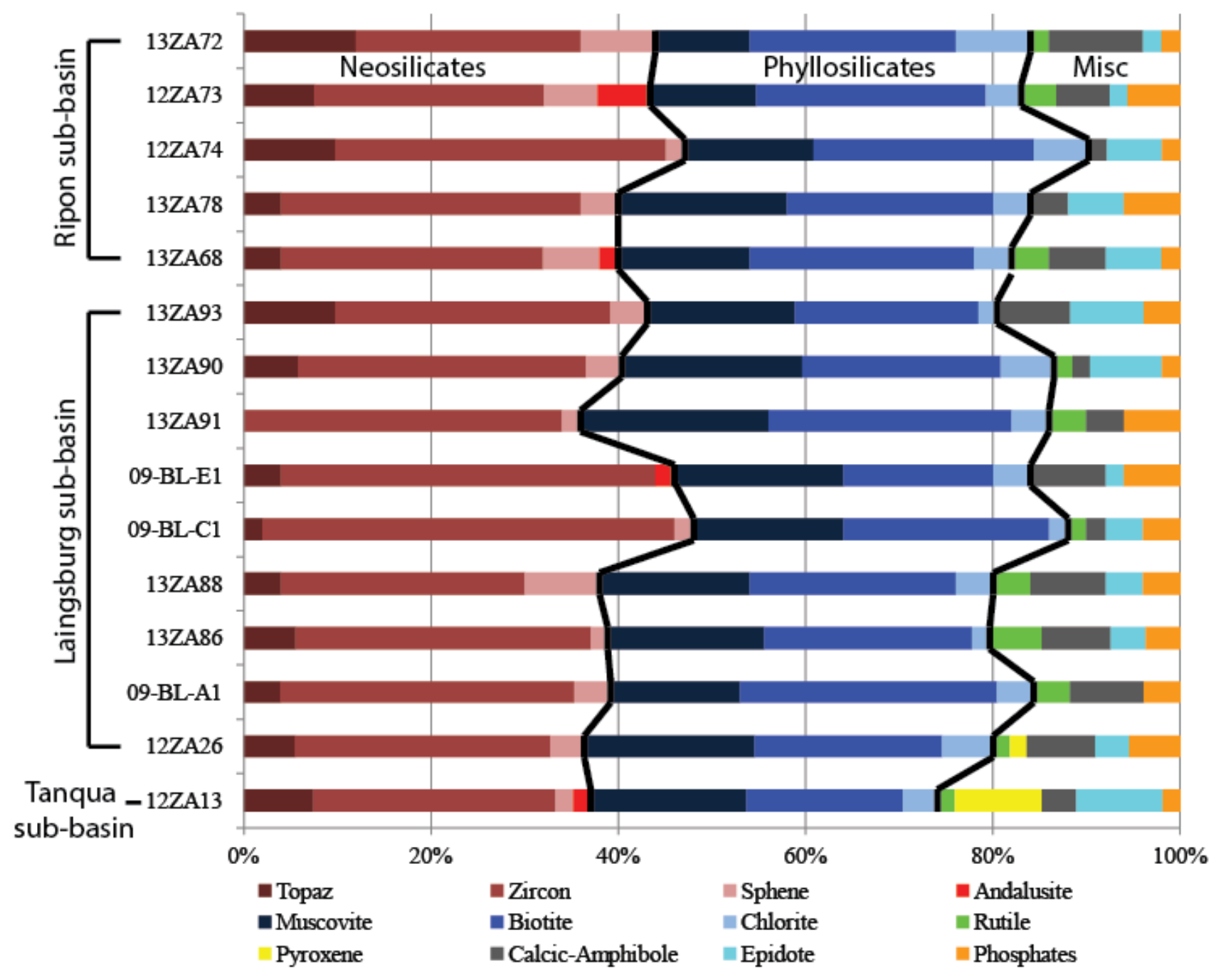

Figure 55: Heavy mineral abundances of 15 sandstone samples collected within the Tanqua, Laingsburg, and Ripon sub-basin 


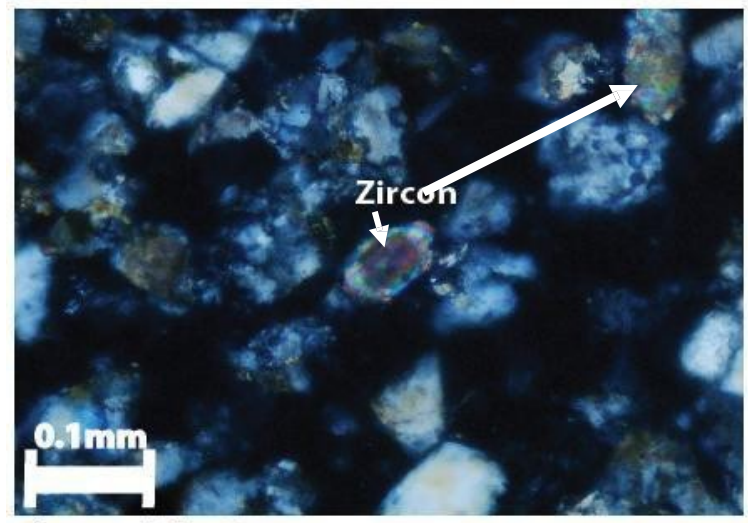

A. 09-BL-C1

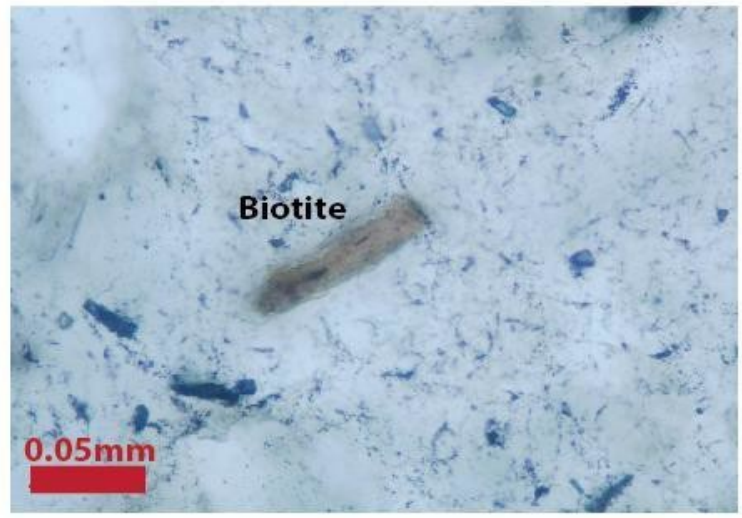

C. $09-B L-A 1$

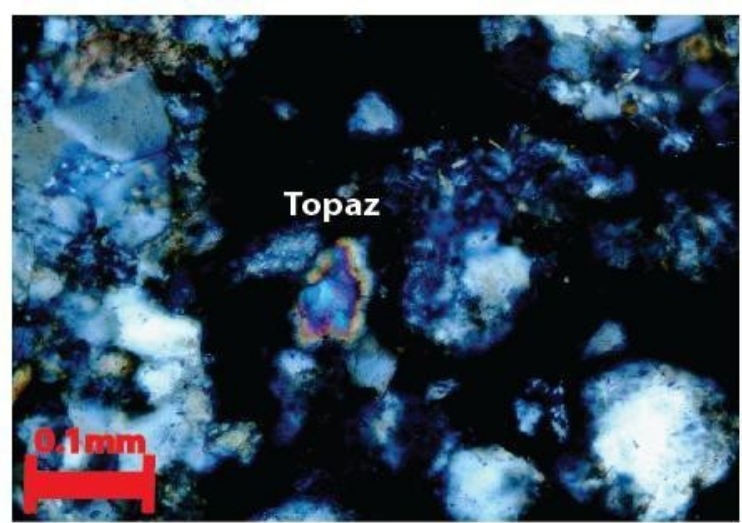

E. 13ZA72

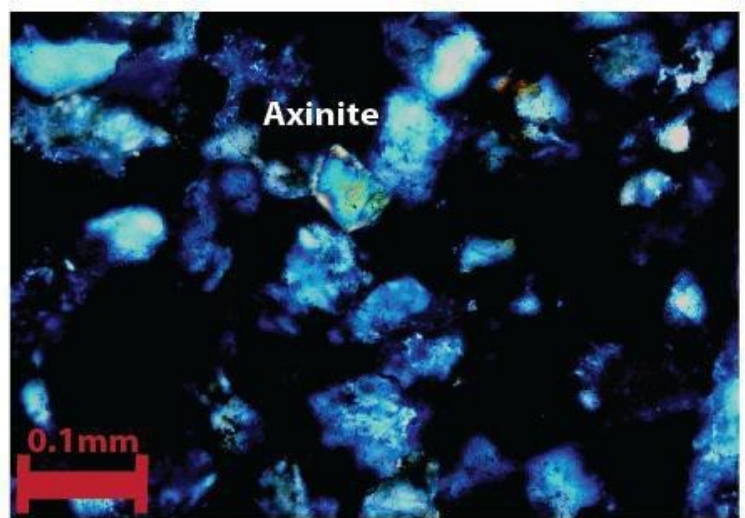

B. 13ZA93

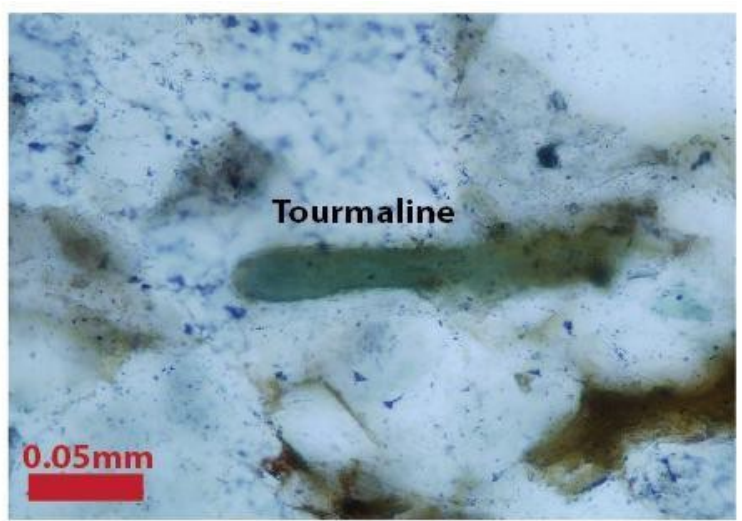

D. $13 Z A 90$

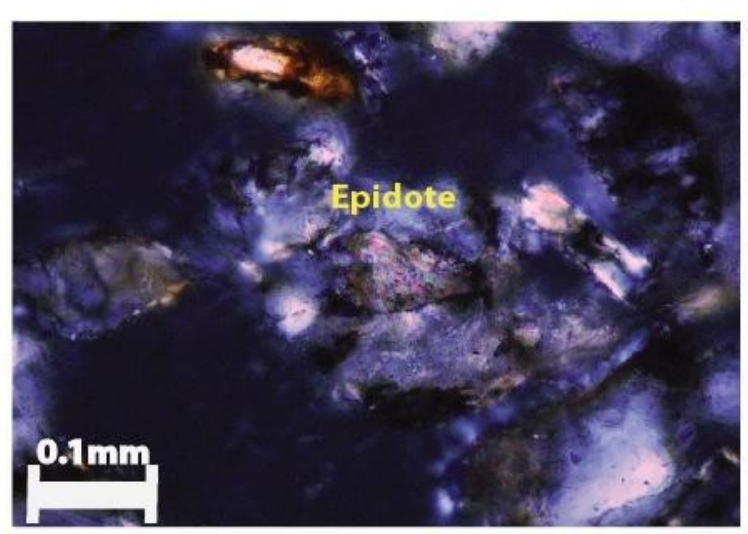

F. $12 Z$ A26

Figure 56: Examples of heavy mineral found in given samples. A) Zircon grains in sample 09-BL-C1 (XPL). B) Axinite grain in sample 13ZA93 (XPL). C) Biotite grain in sample 09-BL-A1 (PPL). D) Tourmaline grain in sample 13ZA90 (PPL). E) Topaz grain in sample 13ZA72 (XPL). F) Epidote Grain in sample 12ZA26 (XPL). 


\section{Chapter IV: Discussion}

\subsection{Potential Source Sediments for the Ecca and Beaufort Groups within the Tanqua, Laingsburg and Ripon Sub-basins}

$\mathrm{U}-\mathrm{Pb}$ detrital zircon geochronology data suggests that approximately six sources may supply sediment into the Karoo basin (Ecca and Beaufort Groups). Two dominant age populations exist within Karoo basin-fill which can be attributed to erosion of rocks formed from tectonic processes occurring along the Panthalassan margin during the Carboniferous-Triassic periods and both Cape Supergroup and per-Cape Supergroup rocks. The two age populations present within all detrital zircon samples are a prominent Permian-Triassic population and a broad Neoproterozoic-Devonian population; a minor population of Carboniferous and Mesoproterozoic-Neoproterozoic zircon are also observed in most samples (Fig. 57). 


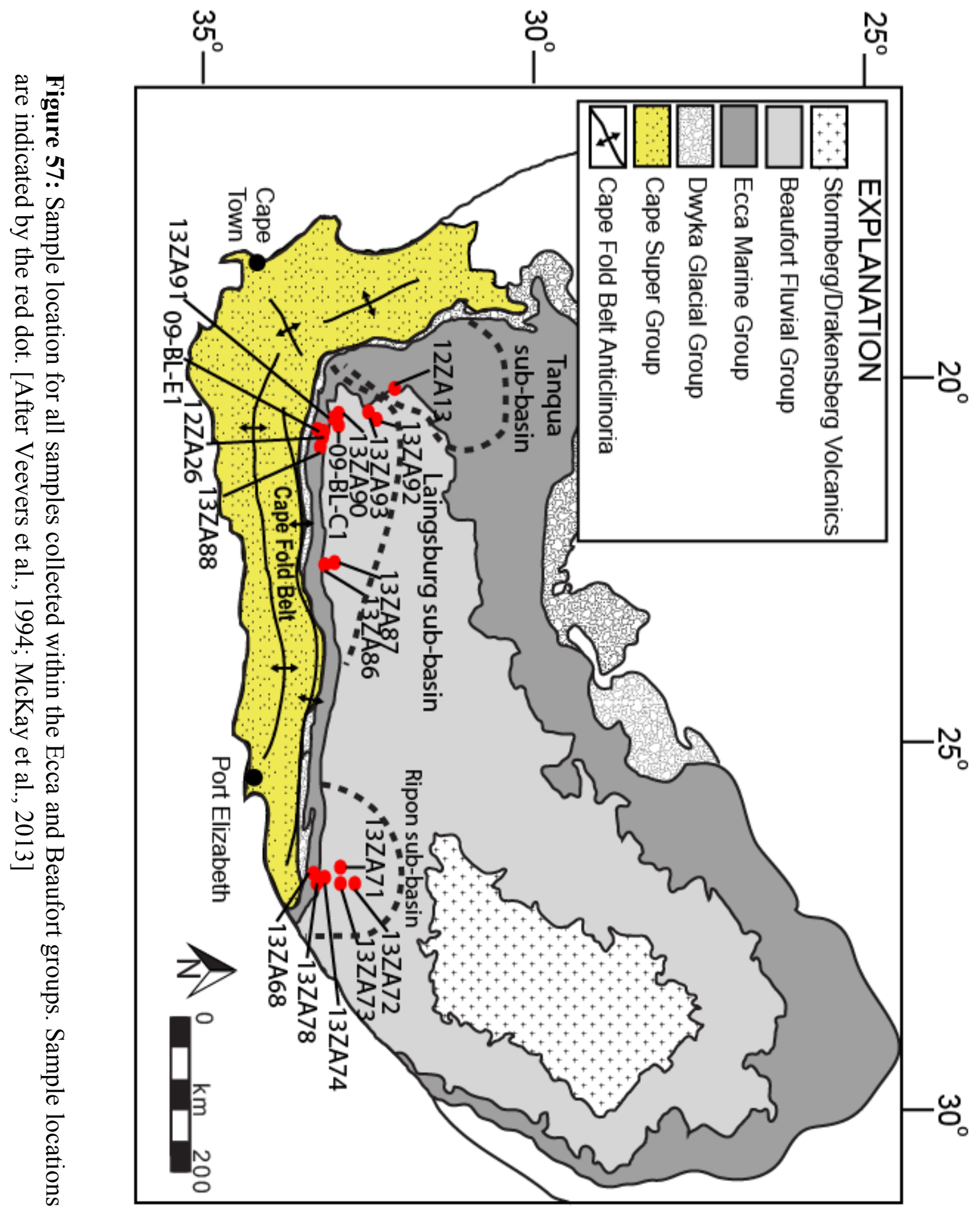




\subsubsection{Permian-Triassic Population}

Probability density diagrams constructed from analyzed U-Pb detrital zircon samples collected from the Ecca and Beaufort Groups in the Tanqua, Laingsburg and Ripon sub-basins reveal two dominant age population with other minor, secondary age components. The first of the two dominant age populations reveals a prominent Permian age component. Permian zircon grain abundances vary slightly within the Ecca and Beaufort Groups which range from $22 \%$ to $40 \%$ of grains within each sample and constitute about $40 \%$ of all grains analyzed combined (Fig. 45 and 58). Triassic grains are found in only two samples, 12ZA13 (7\% of grains, $n=8)$ and 12ZA26 (6\% of grains, $n=6)$ from the Tanqua and Laingsburg sub-basins, however, these grains may be an anomaly due to different calibrations used at different lab facilities (Triassic grains only acquired from samples analyzed at the UC-SC facility: 12ZA26 and 12ZA13) or may be the result of slight lead loss in Triassic grains (Fig. 45). The two Ripon sub-basin detrital zircon samples present similar ages and compositions as the Tanqua and Laingsburg samples. No Triassic aged grains were present in samples 13ZA68 (Ripon Formation) and 13ZA74 (Waterford Formation); however, Permian grains are slightly more prevalent in the Ripon sub-basin than the Tanqua and Laingsburg sub-basins. Permian grains compose from 57\% (13ZA68) to 49\% (13ZA74) of each sample (Fig. 45). However, how juvenile zircons were deposited into the Ripon sub-basin is debated. Sediment from the southern magmatic arc may have entered the basin via the Port Elizabeth antitaxis or sediment derived from the magmatic arc may have been trapped in an intermontane basin for 10-20 Ma and later deposited into the Ripon sub-basin [Booth, 2011].

These Permian grains support the interpretation that Karoo basin fill was sourced by erosion of a magmatic arc that developed to the south of the basin in response to subduction 
during the Late Paleozoic Gondwanide Orogeny [Johnson, 1991]. Due to the presence of compositionally immature turbidite fans present in the Ecca Group interbedded with Permian airfall ash beds, it is likely that the primary sediment source for the middle Ecca to lower Beaufort Group succession was a magmatic arc to the south of the Karoo basin. This is further supported by $\mathrm{U}-\mathrm{Pb}$ age versus $\mathrm{U} / \mathrm{Th}$ ratio plots with a cutoff of four also indicates that these Permian zircon are igneous in origin [Fig. 46]. U-Pb zircon ages between 255- $275 \mathrm{Ma}$ from volcanic ashes present within the Dwyka and lower Ecca Groups were also likely sourced by this southern magmatic arc [Cole, 1992; Fildani et al., 2007]. Permian-Triassic zircons likely entered the Karoo basin (Tanqua and Laingsburg sub-basins) via the Ceres syntaxis which is supported by the similar proportions of $\mathrm{U}-\mathrm{Pb}$ detrital zircon ages, nearly identical mineraological composition and texture of siliciclastic deposits, and north to northeasterly paleocurrent direction within the lower Ecca Group (Skoosteenberg and Laingsburg Formations) [Cole, 1992; Wickens, 1994]. Also, given the similarity in ages of volcanic airfall ashes from Fildani et al. (2007; 2009) and detrital zircon sandstone samples from this study, sedimentation was likely rapid and coeval with active volcanism.

\subsubsection{Neoproterozoic-Devonian Population}

The second most prominent age population is a broad age population ranging from Neoproterozoic to Devonian in age. Figure 58 displays a cumulative probability density diagram in which zircon grains from multiple regional sediment sources likely forms the Neoproterozoic to Devonian age population.

Given the north to northeasterly paleocurrent data collected from the Ecca Group (Veevers et al., 1994), source regions surrounding the margins of the Kalahari Craton can be 
ruled out as the primary sediment sources for the Karoo basin therefore new sources for the Neoproterozoic-Devonian zircon must be considered (Fig. 59). The Neoproterozoic to Devonian population ranges from $16 \%$ to $61 \%$ of grains in each sample and $\sim 40 \%$ of grains in all samples combined (Fig. 45). The majority of grains within this age population are likely sourced from erosion of the Cape Supergroup and Cape Granite Suite due to their proximity to the Karoo basin. Vorster (2013) reported that $30 \%$ to $70 \%$ of detrital zircon grains within the Cape Supergroup are Neoproterozoic in age and were derived from rocks related to the Pan African Orogeny such as the Saldania Belt, Gariep Belt, Damara Belt, and Mozambique Belt to the (south, west, northwest, and northeast respectively) of the Karoo basin (Fig. 59). Vorster (2013) also adds that the Dwyka group contains significant amounts of Neoproterozoic grains which were likely eroded from exposed Pan African Belts during the Carboniferous glaciation. Therefore, it is likely that the Neoproterozoic grains within the Ecca and Beaufort groups may be derived from reworking of the older, underlying Cape Supergroup and Dwyka Group during the Permian. However, the Cape Granite Suite is currently exposed along the southern margin of South Africa, thus, may have been uplifted during Ecca and Beaufort Group deposition to supply first-cycle Neoproterozoic-Devonian zircon to Karoo basin-fill in addition to the contribution of Neoproterozoic-Devonian zircon derived from reworking of the Cape Supergroup. Based on presence of abundant feldspar and quartz revealed by sandstone framework grain compositions, it is likely that both the Cape Supergroup and Cape Granite Suite supplied sediment to Karoo basin-fill causing modal abundance data to plot in the mixed affinity provenance field of the provenance ternary diagrams (Fig. 64, 65, 66, and 67).

Smaller contributions of Ordovician to Devonian grains are also present within the Ecca and Beaufort Groups (17\% of all grains) (Fig. 58). These grains were most likely sourced by 
recycling from the Cape Supergroup and Dwyka Group, or possibly by erosion of terranes lying south of Gondwanna which include; the Deseado Massif, the North Patagonian Massif, and the Sierra Pampeana granite (Fig. 59). Grains supplied by terranes to the south/southwest of the Karoo basin must have crossed the developing Cape Fold belt, possibly via transport through the Ceres syntaxis during the Permian deposition of the Ecca and Beaufort Groups.

Table 6: Regional source material and their associated tectonic events.

\begin{tabular}{|c|c|c|c|c|c|c|}
\hline Tectonic Event & Source Material & Supergroup & Group & $\begin{array}{l}\text { Age of Zircons } \\
\text { (Ma) }\end{array}$ & Lithology & Reference \\
\hline \multirow{4}{*}{$\begin{array}{l}\text { Gondwanide } \\
\text { orogeny }\end{array}$} & Volcanic Arc & & & $245-290$ & Granite/Rhyolite & Fildani et al. (2008) \\
\hline & & \multirow{3}{*}{ Cape (CFB) } & Witteberg & $350-2700$ & Phyllites/Mudrocks & Vorster (2014 \\
\hline & & & Bokkeveld & $400-2700$ & Quartzites/Mudrocks & Vorster (2014 \\
\hline & & & Table Mountain & $400-2700$ & Quartzites & Vorster (2014 \\
\hline & $\begin{array}{c}\text { Dwyka Glacial } \\
\text { Deposits } \\
\end{array}$ & & & $500-3500$ & Glacial Diamectites & $\begin{array}{c}\text { Craddock and Thomas } \\
\text { (2011) }\end{array}$ \\
\hline \multirow[t]{3}{*}{$\begin{array}{c}\text { Pampean } \\
\text { Orogeny }\end{array}$} & Pampia Terrane & & & 384 & Granite & van Lente (2004) \\
\hline & $\begin{array}{c}\text { North Patagonian } \\
\text { Massif }\end{array}$ & & & $235-580$ & $\begin{array}{c}\text { High Grade } \\
\text { Metamorphics and } \\
\text { Granitoids } \\
\end{array}$ & van Lente (2004) \\
\hline & Deseado Massif & & & $344-521$ & $\begin{array}{c}\text { High Grade } \\
\text { Metamorphics and } \\
\text { Granitoids } \\
\end{array}$ & $\begin{array}{l}\text { Moreira et al. (2013); } \\
\text { Pankhurst et al. (2003 }\end{array}$ \\
\hline \multirow{3}{*}{$\begin{array}{c}\text { Pan African } \\
\text { Orogeny }\end{array}$} & \multirow[b]{2}{*}{ Saldania Belt } & Cape Granite Suite & & $515-555$ & Granite & Kisters et al. (2002) \\
\hline & & Malmesbury & & $520-580$ & $\begin{array}{c}\text { Metasedimentary Rocks } \\
\text { and Granitods }\end{array}$ & Rozendaal et al. (1999) \\
\hline & GariepBelt & & & $507-529$ & $\begin{array}{c}\text { Metasedimentary Rocks } \\
\text { and Granitods }\end{array}$ & $\begin{array}{c}\text { Smithies (1992); Frimmel } \\
(2000)\end{array}$ \\
\hline Damara Orogeny & Damara Belt & & & $488-650$ & $\begin{array}{c}\text { Medium to High-Grade } \\
\text { Metamorphics and } \\
\text { Grainites }\end{array}$ & Kröner and Stern (2004) \\
\hline $\begin{array}{c}\text { East African } \\
\text { Orogeny }\end{array}$ & Mozambique Belt & & & $500-1100$ & $\begin{array}{c}\text { Medium to High-Grade } \\
\text { Metamorphics and } \\
\text { Grainites }\end{array}$ & Meert (2003) \\
\hline \multirow[t]{2}{*}{$\begin{array}{c}\text { Namaqua-Natal } \\
\text { Orogeny }\end{array}$} & $\begin{array}{l}\text { Namaqua-Natal } \\
\text { Province }\end{array}$ & & & $1000-2100$ & $\begin{array}{l}\text { Medium to High-Grade } \\
\text { Metamorphic Rocks }\end{array}$ & Eglington (2006) \\
\hline & Kaapvaal Craton & & & $>1800$ & $\begin{array}{c}\text { High Grade } \\
\text { Metamorphics and } \\
\text { Volcanics }\end{array}$ & Jahn and Condie (1995) \\
\hline
\end{tabular}




\subsubsection{Carboniferous and Paleoproterozoic-Mesoproterozoic Populations}

Carboniferous and Paleoproterozoic-Mesoproterozoic populations within the Ecca and Beaufort Groups are relatively minor with respect to the two prominent age populations discussed above. Carboniferous grains are likely sourced from detrital grains contained by the Cape Supergroup, however; these grains suggest sediment influx from source regions to the south of Gondwanna, such as the Deseado Massif and North Patagonian Massif (Fig. 67). The Paleoproterozoic-Mesoproterozoic population is very minor in all samples ranging from a few grains to single grains (Fig 58). These grains are likely the result of recycling of older sedimentary rocks such as the Cape Supergroup and Dwyka Group which contain these older zircon grains [Vorster, 2013]. Ultimately these grains were probably contributed to the Cape Supergroup and Dwyka Group from the Kaapvaal Craton and Namaqua-Natal Province which were sources of the Cape Supergroup [Vorster, 2013].

Overall, detrital zircon samples collected within the Ecca and Beaufort Groups contain relatively uniform age populations with only slight variations in grain contributions in the Tanqua, Laingsburg, and Ripon sub-basins, and therefore are all likely sourced from the same sediment sources. 


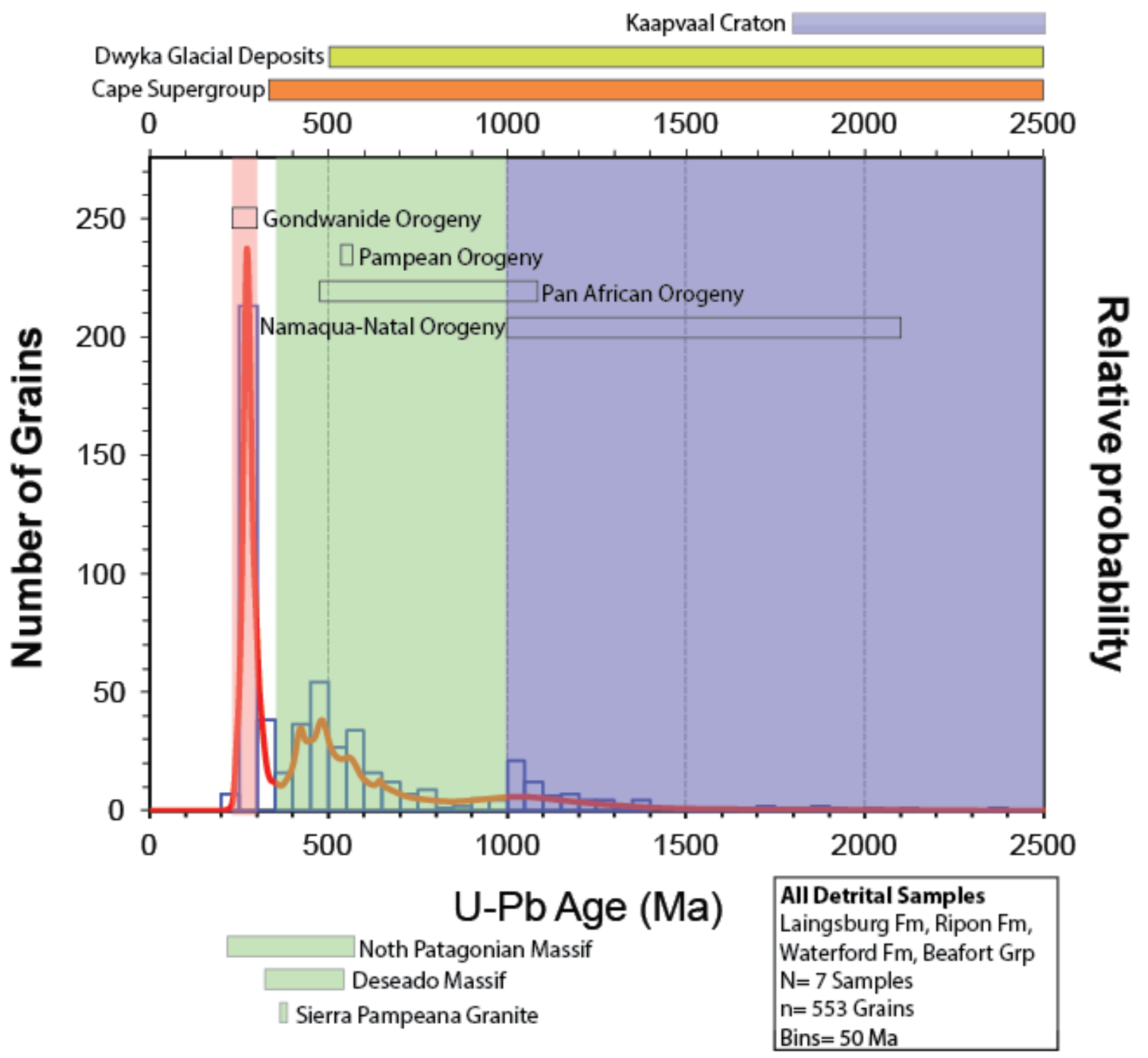

Figure 58: Cumulative probability density diagram including zircon age data from all seven detrital zircon samples (553 grains). Grains were derived from rocks that formed as the result of four tectonic events (Gondwanide Orogeny, Pampean Orogeny, Pan African Orogeny, and the Namaqua- Natal Orogeny), amalgamated terranes and massifs (North Patagonian Massif, Deseado Massif, and the Kaapvaal Craton), glacial deposits (Dwyka Glacial Group), and passive margin sediment uplifted by the Gondwanide Orogeny (Cape Supergroup). The colored boxes with the plot area correspond to prominent age populations in all samples $($ Red= Permian-Triassic; Green= Neoproterozoic-Devonian; and Blue $=$ Mesoproterozoic and older). Colored, labeled boxes outside of the plot area are source terranes or lithologic groups which contain grains of corresponding age to prominent age group outline inside the plot area. The Cape Supergroup and Dwyka Group glacial deposits contain grains which span across prominent age thresholds and likely only contain grains from older units due to erosional resampling. Refer to Table 2 for ages of all potential source material and references. 


\subsection{Zircon Source Comparison}

Dominant $\mathrm{U}-\mathrm{Pb}$ detrital zircon age populations can easily be compared to regional source data using a stacked, normalized relative probability density diagram. The prominent Permian age population is present within all detrital zircon samples and matches late stage North Patagonian Massif igneous events. These events were likely a result of active tectonism along the Panthalassan margin. The 400-750 Ma population matches several source terranes. Detrital grains within this age population match zircon ages from the entire Cape Supergroup, Cape Granite, and North Patagonian Massif (Fig. 59). These grains are likely products of the Pan African Orogeny. Lastly, the 900- 1300 Ma population is relatively minor in the detrital samples. These grains are likely soured from the Cape Supergroup. Grains of this age were probably the source for Cape Supergroup sediment and are now a product of erosional resampling in which rocks that sourced the Cape Supergroup are now being eroded from the out of the Cape Supergroup and deposited in the Karoo basin.

$\mathrm{K}-\mathrm{S}$ tests performed on each of the detrital samples suggest that the juvenile age population in each sample are statistically similar, therefore, are likely from the same source (Table 2). K-S tests were not performed by comparing older grains within each detrital sample to published (potential) source data because 1) older aged grains tend to be slightly dispersed in detrital samples and published data which has an adverse effect of K-S tests and 2) some detrital samples contain less than 20 grains of older age populations causing the K-S test to be statistically meaningless. 


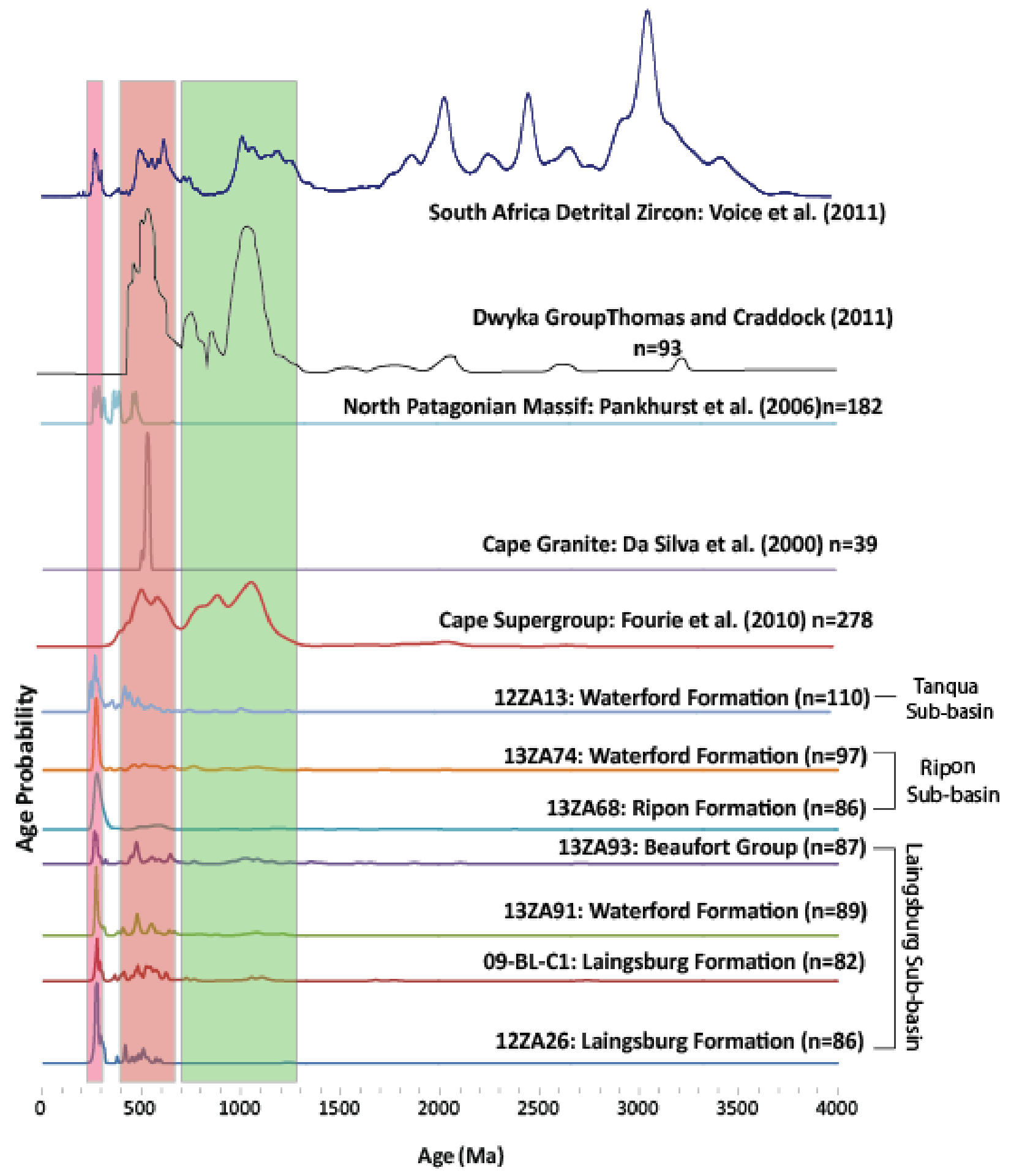

Figure 59: Normalized relative probability density diagram showing the relationship between detrital samples and proposed source terranes/sediments. 


\subsection{KDE Versus Probability Density Plots}

The use of KDE plots versus probability density plots for detrital zircon geochronology is a topic for debate. The view of the Arizona Laserchron lab is that probability density plots are appropriate to use for detrital zircon data because they provide a robust depiction of the measured ages and uncertainties [www.laserchron.org]. KDE plots assesses detrital zircon data by increasing the uncertainty of each age which effectively smoothes the entire age distribution. This approach, however, may not be useful for detrital zircon data sets because the measured age distribution approaches the true age distribution with increasing analysis with the main change being the proportion of ages rather and the distribution of ages in each population [www.laserchron.org]. This study uses and compares both KDE (Fig. 22, 25, 28, 22, 36, 40, and 43) and probability density plots (Fig. 21, 24, 27, 31, 35, 39, and 42). In general, the difference between KDE and probability density plots in negligible in which the smoothness of the curve is affected and some age populations are slightly shifted in some samples.

\subsection{Geospatial Trends of the Ecca and Beaufort Sandstone Compositions}

From the 18 point counted samples, (from the Tanqua, Laingsburg, and Ripon subbasins) several trends were observed. The texture and compositions of all samples were relatively uniform despite stratigraphic and basin location. Previous provenance studies conducted by King et al., (2004) and Johnson, (1991) differ significantly in Karoo sandstone composition causing their data points to plot mostly in the mixed and transitional continental provenance fields and the transitional arc provenance field (Fig. 60 \& 61). However, these studies likely differ significantly due to the lack of stratigraphic resolution within each sub- 
basin and the sampling of different units across sub-basin boundaries. This study produces slightly different provenance for the Ecca and Beaufort sandstones in the Tanqua, Laingsburg, and Ripon sub-basin when compared to the results from King et al. (2004) and Johnson (1991).

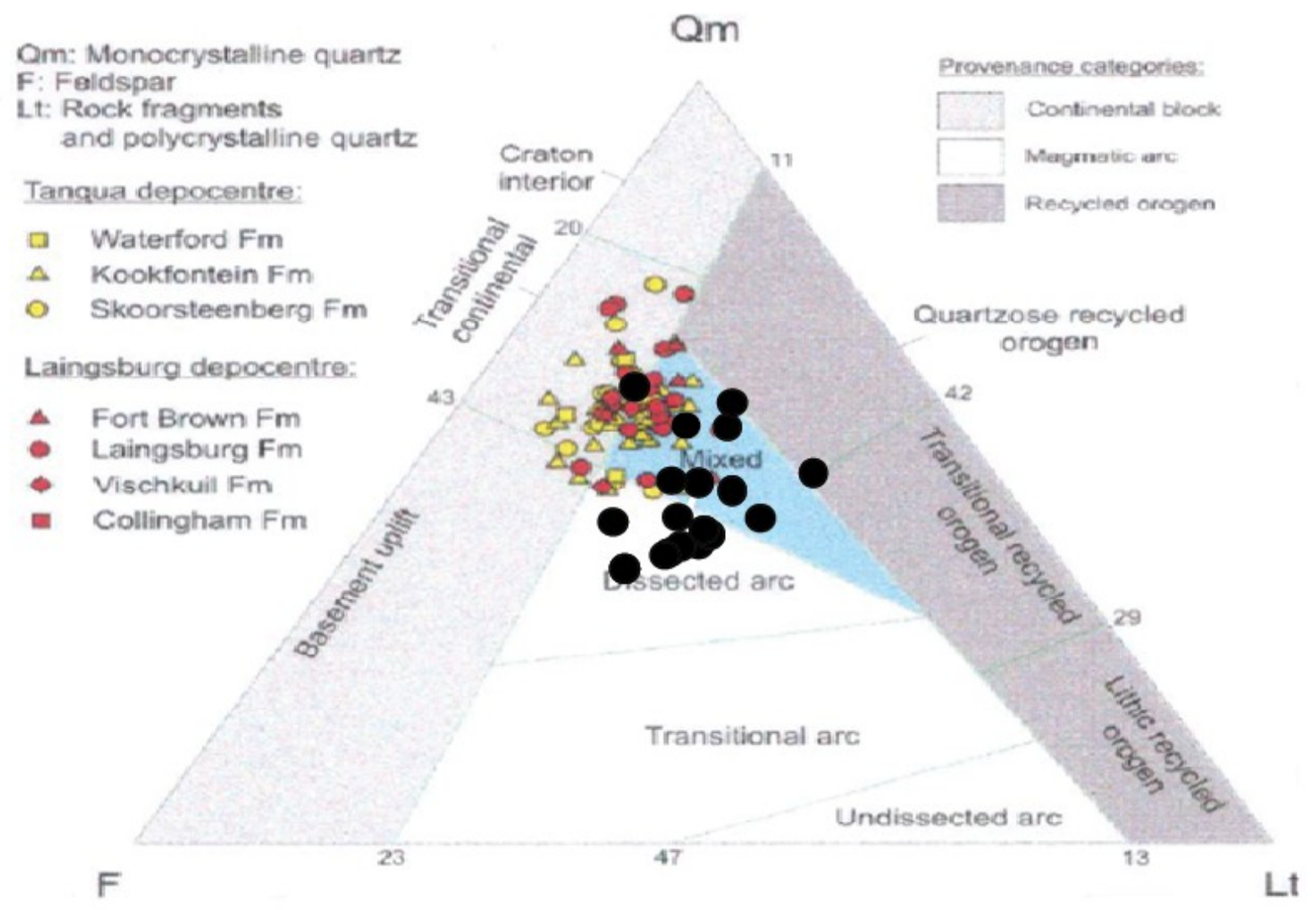

Figure 60: QmFLt ternary diagram of Tanqua and Laingsburg sub-basin sandstones. Note the similar composition and provenance of the sandstones in both sub-basins. The black points represents the data from this study [Taken from King et al., 2004; Provenance fields from Dickinson et al., 1983] 


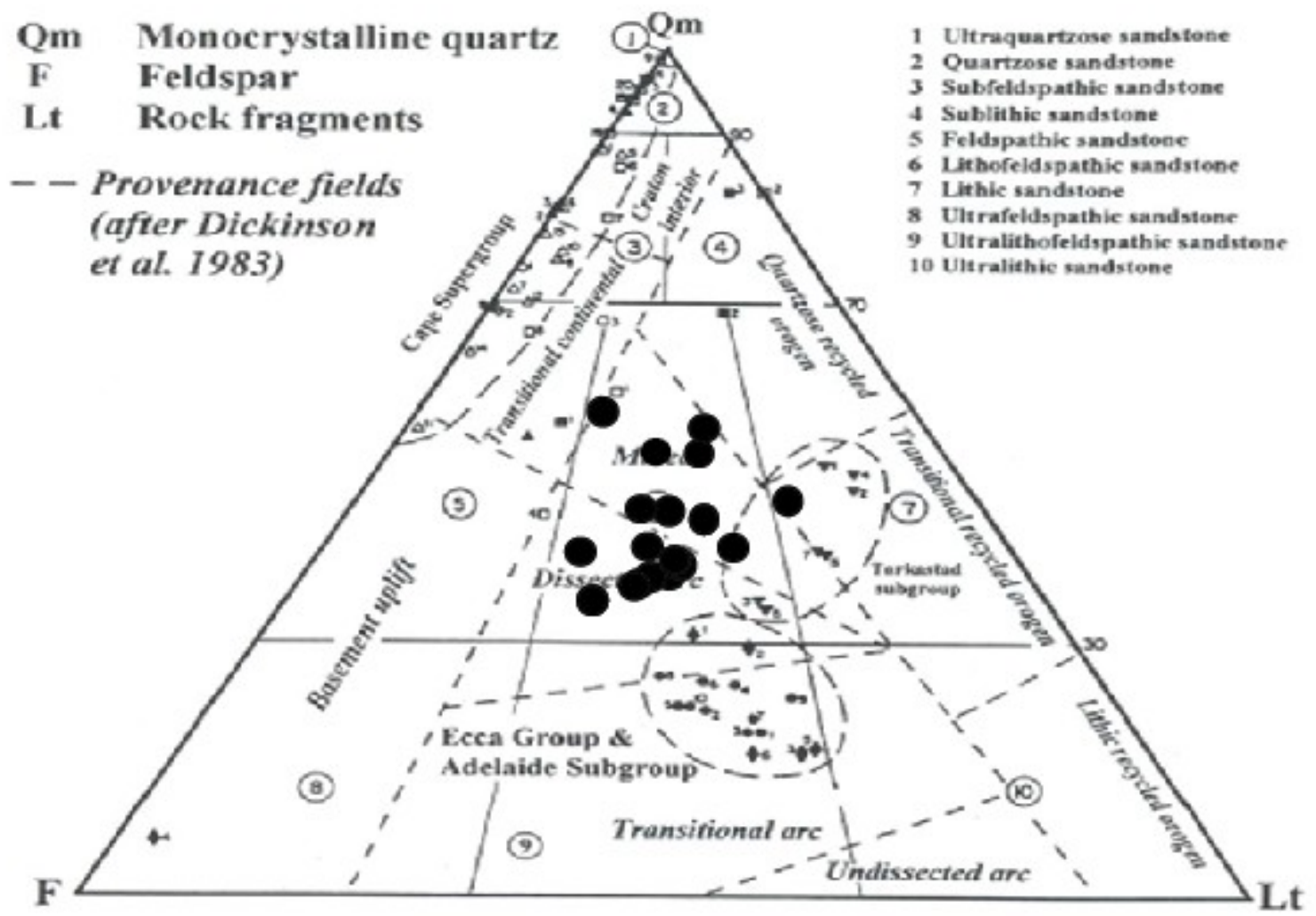

Figure 61: QmFLt ternary diagram of Ecca Group sandstones. Ecca Group sandstones (Waterford Formation: 1,2, \& 3; Fort Brown Formation tuff: 4; and Ripon Formation: $5 \& 6$ ) are indicated by the black diamonds. The black points represents the data from this study. Note the difference in provenance from King et al. (2004) (Fig. 60). [Taken from Johnson, 1991]

\subsubsection{Ripon Sub-basin}

The six point counted samples from the Ripon sub-basin contain slightly varying amounts of mineralogical abundances within each sample. The samples appear to display an overall increase in total quartz grains up section (Ripon Formation: 42\% to Beaufort Group: 59\%) whereas total lithic grains appear to decrease upwards (Ripon Fm: 35\% to Beaufort Group: 14\%) (Fig. 50, 54 \& 62). Total feldspar grains vary slightly throughout the section with no evident trend present. Volcanic and Metamorphic lithic grains are very minor 
constituents in all samples whereas sedimentary lithic grains are the dominant lithic type. The majority of sedimentary lithic grains appear to be chert and other rock fragments. This is consistent with the hypothesis that Karoo sediments may have been partially sourced by the Dwyka Group due to the Dwyka group being the only chert bearing rock in the region [Visser et al., 1986].

On the QmFLt and QtFL diagrams, (Fig. 62) all samples plot in either mixed affinity, recycled orogenic or dissected arc fields. These data likely represent the result of source mixing in which nearly equal amounts of multiple source terranes of varying lithology (Cape Supergroup, Cape Granite, Dwyka Group and, southern magmatic arc) supply sediment to the Karoo basin causing data points to plot in the mixed and dissected arc diagram fields. Points plotting in the recycled orogenic field of the QtFL diagram are appear to be more quartz-rich due to the presence of polycrystalline quartz that was likely derived from the quartzite portions of the Cape Fold Belt (Fig. 60). LmLvLs diagrams indicate that sedimentary lithics are the most dominant lithic type within these samples. Lithic grains range from sedimentary fragments and microcrystalline chert grains. Chert grains may be derived from chert clasts contained by the Dwyka Group, isolated highly silicified fine grain sandstones in the lower Ecca, and/or silicified ashes within the Dwyka and Ecca Groups [Rubidge et al., 2000]. The moderate amount of feldspar within these samples was likely derived from the Cape Granite Suite and/or igneous events related to the North Patagonian Massif as well as the Sierra Pampeana granites; and buried rapidly to prevent weathering.

Overall, the Ripon sub-basin sandstone composition is highly similar to that of sandstones within the Tanqua and Laingsburg sub-basins, however, zircon age populations differ slightly. Ripon sub-basin sandstone samples appear to contain a higher abundance of 
zircons source from the magmatic arc and slightly less contribution from the Cape Supergroup when compared to the samples from the Tanqua and Laingsburg sub-basins. This could be caused by the CFB's resistance to physical weathering or its absence during the deposition of these sediments. 

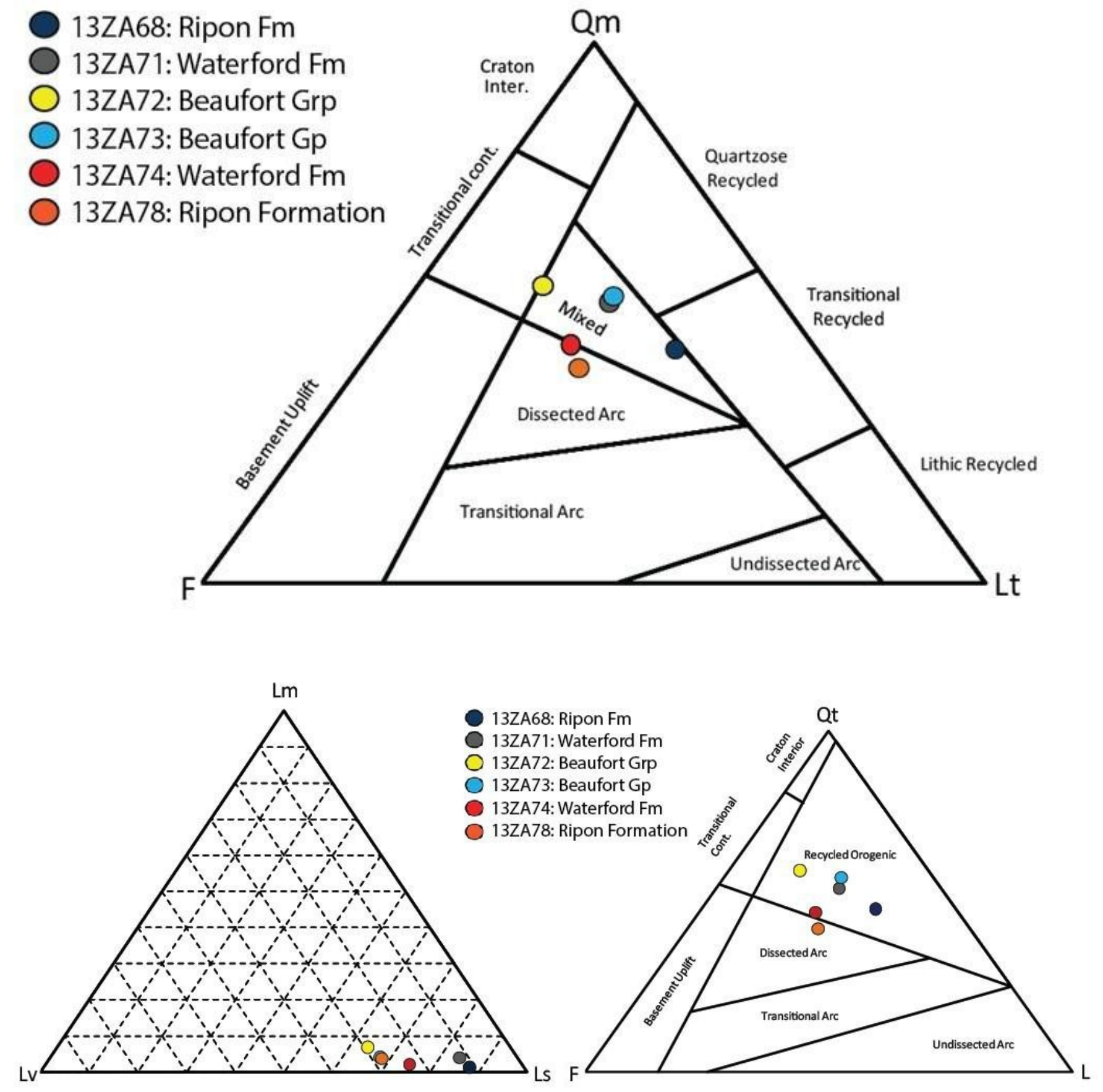

Figure 62: Qm FLt, QtFL, and LmLvLs diagrams for samples from the Ripon sub-basin. Diagram fields after Dickinson (1983). 


\subsubsection{Laingsburg Sub-basin}

The eleven point counted samples from the Laingsburg sub-basin contain relatively uniform amounts of mineralogical abundances within each sample. The samples contain amounts of total quartz ranging between $30-53 \%$ with higher amounts in the Beaufort Group (13ZA93: 53\%) (Fig. 51, 52 \& Fig. 54). Total feldspar grains (22-36.5\%) vary slightly throughout the section with a slight decreasing trend upward from the Waterford Formation to the Beaufort Group. Volcanic and Metamorphic lithic grains are very minor constituents in all samples whereas sedimentary lithic grains are the dominant lithic type (Fig. 63 \& Fig. 64). The majority of sedimentary lithic grains are chert along with other rock fragments. This is consistent with the hypothesis that Karoo sediments may have been partially sourced by the Dwyka Group due to the Dwyka group being the only chert bearing rock in the region (Visser et al., 1986).

On the QmFLt and QtFL diagrams, (Fig.63 \& Fig. 64) all samples plot in either mixed affinity, recycled orogenic or dissected arc fields. These data likely represent the result of source mixing in which nearly equal amounts of multiple source terranes of varying lithology (Cape Supergroup, Cape Granite, Dwyka Group and, southern magmatic arc) supply sediment to the Karoo basin causing data points to plot in the mixed and dissected arc diagram fields. In general, samples within the Laingsburg sub- basin have very little polycrystalline quartz $(<$ 10\%) causing little change in QtFL and QmFLt diagrams (Fig. 54, 63 \& 64). LmLvLs diagrams indicate that sedimentary lithics are the most dominant lithic type within these samples. Lithic grains range from sedimentary rock fragments and microcrystalline chert grains. Chert grains may be derived from chert clasts contained within the Dwyka Group, isolated highly silicified fine grain sandstones in the lower Ecca, and/or silicified ashes within 
the Dwyka and Ecca Groups [Rubidge et al., 2000]. The moderate amount of feldspar within these samples is likely derived from the Cape Granite Suite and/or igneous events related to the North Patagonian Massif as well as the Sierra Pampeana granites; and buried rapidly to prevent weathering.

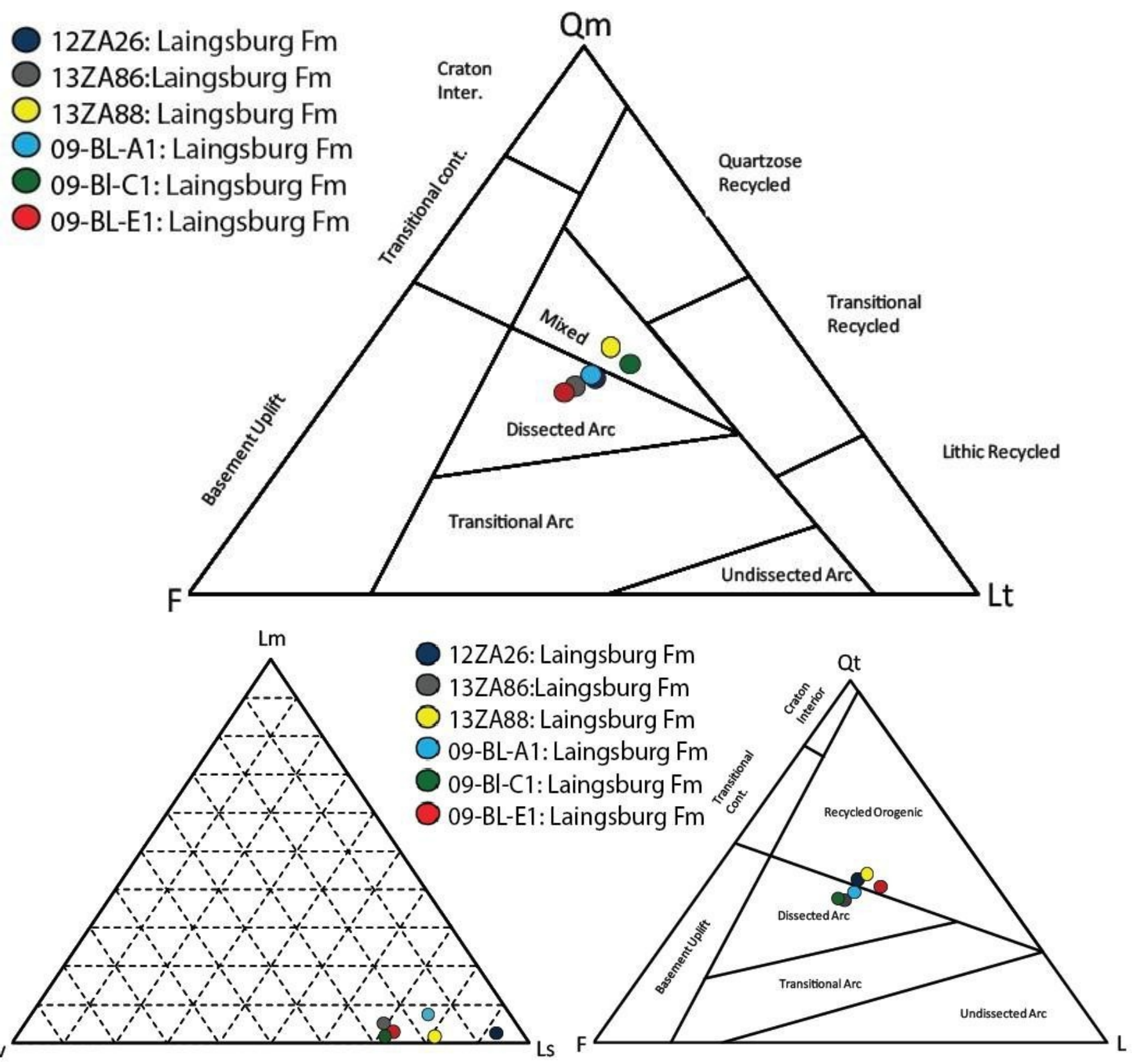

Figure 63: Qm FLt, QtFL, and LmLvLs diagrams for samples from the Laingsburg sub-basin. Diagram fields after Dickinson (1983). 

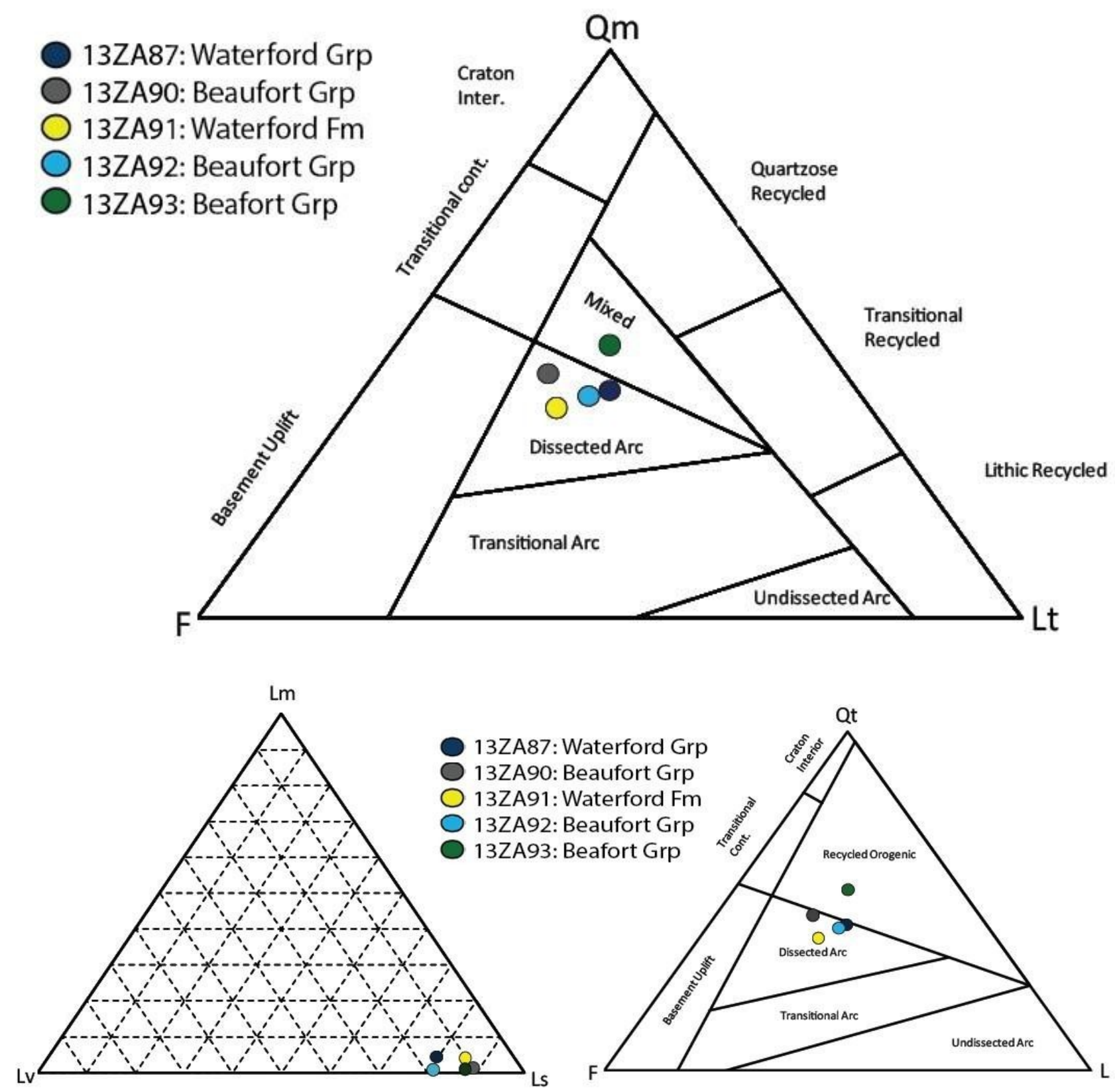

Figure 64: Qm FLt, QtFL, and LmLvLs diagrams for samples from the Laingsburg sub-basin. Diagram fields after Dickinson (1983). 


\subsubsection{Tanqua Sub-basin}

The single point counted sample from the Tanqua sub-basin contains variable amounts of mineralogical abundances compared to samples collected in the Tanqua and Laingsburg sub-basins. This sample appears to contain slightly higher amounts of total quartz (57\%) compared to other analyzed samples (Fig. 53 and Fig. 54). Total feldspar grains (22\%) are slightly variable with respect to other Waterford samples (13ZA74: 29\%; 13ZA91: 36\%). Volcanic and Metamorphic lithic grains are very minor constituents within this sample whereas sedimentary lithic grains are the dominant lithic type (Fig. 65). The majority of sedimentary lithic grains are chert along with other rock fragments. This is consistent with the hypothesis that Karoo sediments may have been partially sourced by the Dwyka Group due to the Dwyka group being the only chert bearing rock in the region (Visser et al., 1986).

On the QmFLt and QtFL diagrams, (Fig. 65) for this sample plot in the mixed affinity and recycled orogenic or dissected arc fields. This data likely represents the result of source mixing in which nearly equal amounts of multiple source terranes of varying lithology (Cape Supergroup, Cape Granite, Dwyka Group and, southern magmatic arc) supply sediment to the Karoo basin causing data points to plot in the mixed and dissected arc diagram fields. In general, the sample within the Tanqua sub- basin has very little polycrystalline quartz $(<10 \%)$ causing little change in QtFL and QmFLt diagrams (Fig. 54 and Fig. 65). The LmLvLs diagram indicates that sedimentary lithics are the most dominant lithic type within this sample. Lithic grains range from sedimentary rock fragments and microcrystalline chert grains. Chert grains may be derived from chert clasts contained within the Dwyka Group, isolated highly silicified fine grain sandstones in the lower Ecca, and/or silicified ashes within the Dwyka and Ecca Groups [Rubidge et al., 2000]. The moderate amount of feldspar within these samples is 
likely derived from the Cape Granite Suite and/or an igneous event related to the North Patagonian Massif as well as the Sierra Pampeana granites; and was buried rapidly to prevent weathering.

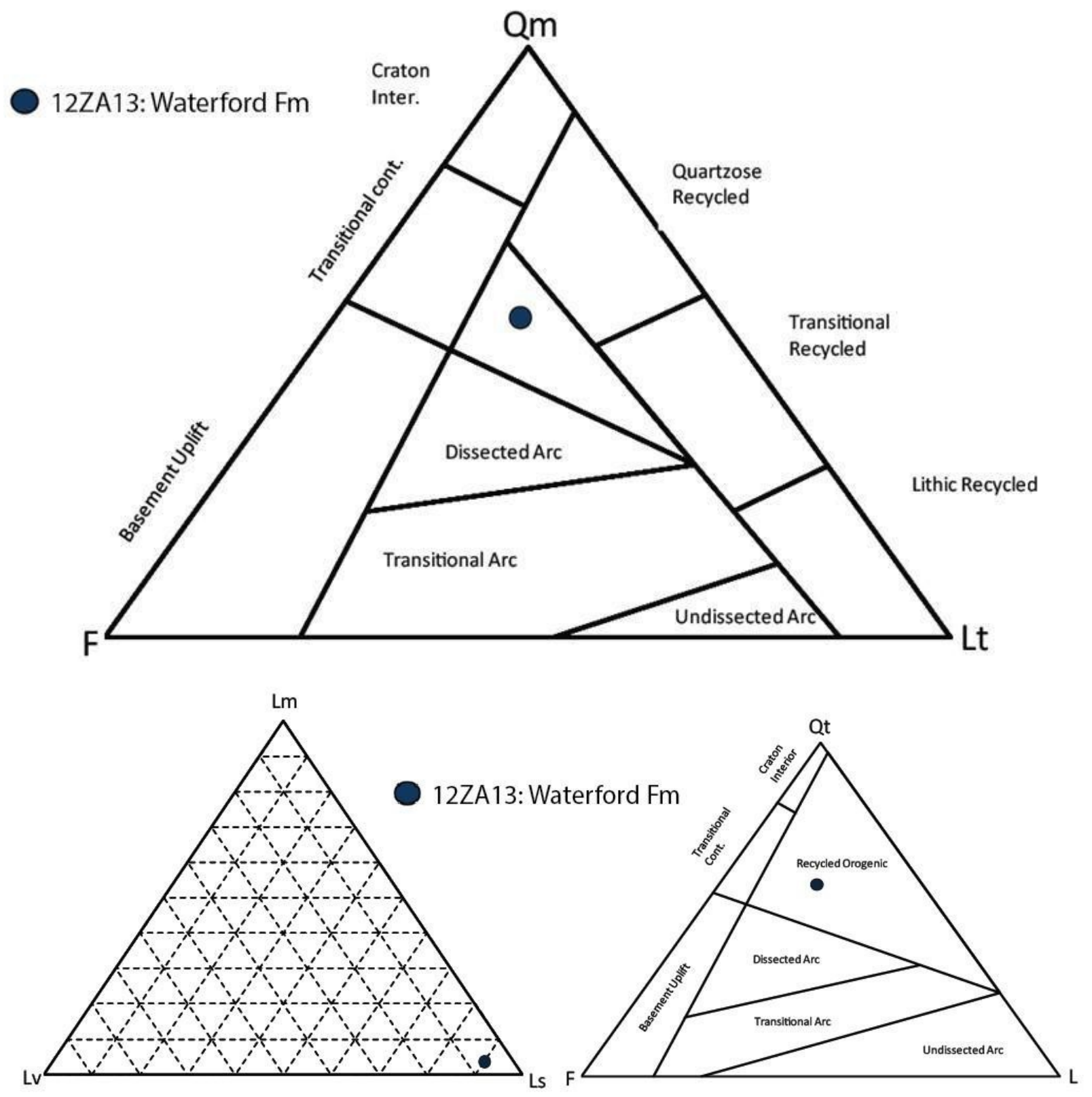

Figure 65: Qm FLt, QtFL, and LmLvLs diagrams for samples from the Tanqua subbasin. Diagram fields after Dickinson (1983). 


\subsection{Heavy Mineral Abundance Trends}

Geospatial trends in heavy mineral assemblages can be observed within all analyzed samples. The Laingsburg Formation turbidite fan samples contain slightly more zircon grains than analyzed samples higher in the stratigraphy (Waterford Formation and Beaufort group). Topaz grains are common in low abundances throughout all samples with the exception of sample 13ZA91 (Fig. 55). Topaz is a relatively common mineral found in granites which may be a Cape Granite Suite provenance indicator. Phyllosilicates phosphates are uniform throughout all samples which may indicate Cape Supergroup and Cape Granite provenance; however, these minerals are relatively common in all types of igneous rocks as well as gneisses, greenschist, and amphibolites facies. Sphene is also present in low amounts in all samples. Sphene could indicate end- phase magmatism associated with arc magmatism off the southern coast of Gondwanna. Overall samples contain relatively uniform heavy mineral assemblages and most heavy minerals present within all samples are common minerals in" two-mica grainites" which contain both muscovite and biotite with low amounts of hornblende [Armstrong and Boudette, 1984]. There is little evidence suggesting the weathering of other sedimentary rocks or metamorphic rocks due to the low amounts of metamorphic mineral phases.

\subsection{Sediment Pathways}

\subsubsection{Ceres syntaxis}

The Ceres syntaxis also known as the Hex River anticlinoria represents a $40-80^{\circ}$ turn in the Cape Fold Belt as a result of right-lateral transpression [Johnston, 2000] (Fig. 7). The Ceres syntaxis is also the result of topographic inversion in which the structural high was 
incised to create pathway through the Cape Fold Belt [Brezinski, 1989]. The Ceres syntaxis is located northeast of Cape Town and separates the two branches of the Cape Fold Belt. Formation of the Ceres syntaxis also resulted in the development of the Tanqua and Laingsburg sub-basins [Wickens, 1994]. The Tanqua and Laingsburg sub- basins present a similar mixture of depositional ages whereas the composition of siliciclastic deposits in both sub-basins is nearly identical [Fildani et al., 2007]. Due to the presence of an extensive magmatic arc positioned along the southern margin of Gondwana and a prominent Permian age component present in Karoo basin-fill, an isolated sediment pathway through/around the Cape Fold Belt must have existed in order to deliver detritus to the Karoo basin. The Ceres syntaxis may have served as this pathway.

\subsubsection{Port Elizabeth Anti-taxis}

The Port Elizabeth antitaxis lies to the north of Port Elizabeth and formed in response to right-lateral transpression produced by the Gondwanide Orogeny [Johnston, 2000]. The Ripon sub-basin lies to the north of the Port Elizabeth antitaxis and contains the same juvenile Permian age component as the Laingsburg sub-basin. It is possible that Port Elizabeth antitaxis contained sediment pathways around its flanks allowing sediment to be transported from the active volcanic arc to the Karoo basin. It is also possible that Port Elizabeth antitaxis was the result of present day tectonic processes associated with the Agulhas Falklands Fracture Zone and had no impact on sediment delivery into the Karoo basin during the Permian [Booth, 2011]. 


\subsection{Detrital Versus Airfall Ash Ages: Laingsburg Sub-basin}

Maximum deposition ages acquired from this study can be compared to airfall ashes found within the same stratigraphic interval. Detrital zircon maximum depositional ages were determined by taking a weighted average (using Microsoft Office Excel with and Isoplot 4.1 add-in) of the youngest age population that has not experienced discernible lead loss. The weighted average is determined by averaging all selected data points and weighting them by the inverse square of their assigned errors. It has been proposed that airfall ash ages may become "out of sequence" up section into the Beaufort group, [McKay pers. comm.] that is, stratigraphically older zircon ages appear above younger aged zircons (assuming no structural juxtaposition has occurred) violating Stenos law of superposition [Steno, 1669].

Figure 55 displays detrital zircon and ash ages produced within the Lower Ecca Group and above and below the Ecca/Beaufort contact. In the lower Ecca, sample 12ZA26 lies between two ash ages. The maximum depositional age of sample 12ZA26 is $265 \pm 4.4$ Ma which appears to be "in-sequence" with the ash ages of $272.2 \pm 3 \mathrm{Ma}$ and $263.8 \pm 2.2$ Ma respectively above and below the detrital zircon sample (Fig. 66). Farther up section in the Middle Ecca, sample 09BL-C1 yields a maximum depositional age of $270 \pm 5$ Ma which is "out-of- sequence" with the ash ages of $254.3 \pm 3 \mathrm{Ma}$ and $248.9 \pm 2.6 \mathrm{Ma}$ respectively above and below the sample. This could be due to internal "lag time" within the system in which, assuming all zircon grains are autocrystic (i.e., from the same source as airfall ash), the time required for sediment to deposited causes the age separation between detrital zircon maximum depositional ages and airfall ash ages due to the different modes of sediment transportation. The two detrital samples above and below the Ecca/Beaufort contact (13ZA91 and 13ZA93) yield maximum depositional ages of $269 \pm 2$ Ma and $262 \pm 1.5 \mathrm{Ma}$, respectively, which appear to be "in-sequence" with the ash age of $262 \pm$ 3.6 Ma above, however; the ash age is "out- of-sequence" being $14 \mathrm{Ma}$ older than the ash age 
below it (Fig. 66). It is likely that the $262 \pm 3.6$ Ma ash age comes from xenocrystic zircons which may have been assimilated from older plutonic rock that had previously crystallized within the magmatic system. An alternative hypothesis may be that the ash was detritally contaminated or reworked to incorporate older zircon from underlying strata.

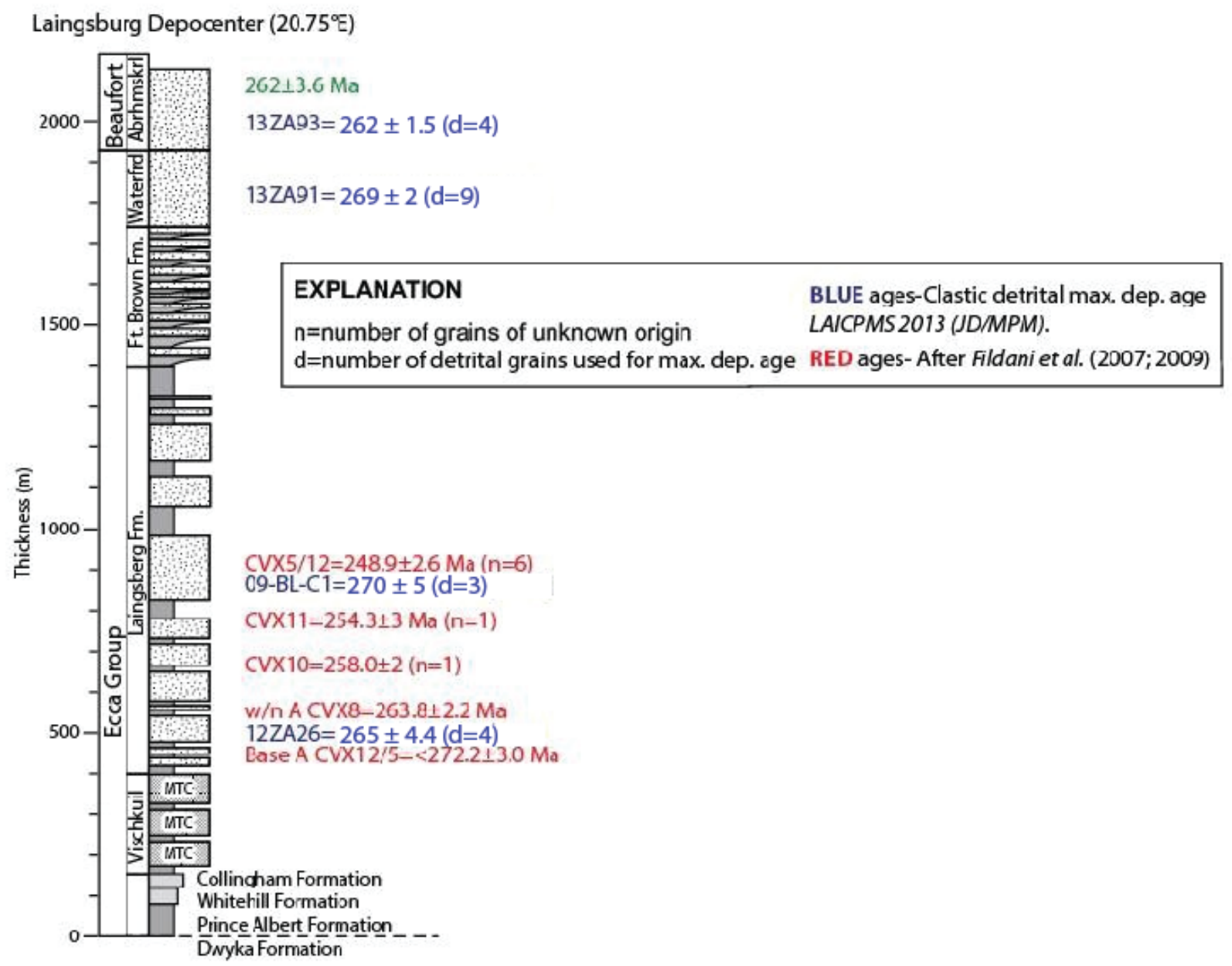

Figure 66: Composite stratigraphic column of the Laingsburg sub-basin displaying the relationship between airfall ash ages and detrital zircon ages. Thicknesses for formations from Visser (1993), Faure and Cole (1999), Grecula et al. (2003), Hodgson et al. (2006), King (2005), Wild (2005), Sixsmith et al. (2004), and McKay, pers. comm.. 


\subsection{Karoo basin Model}

The Karoo basin of South Africa represents a major Late Paleozoic-Early Mesozoic Gondwanan depocenter produced by active convergent tectonism along the Panthalassan margin (Fig. 68) [Fildani et al., 2008]. U-Pb detrital zircon analyses suggests that the volcanic arc to the south of the Karoo basin was likely a primary sediment source for Karoo basin fill. Sediment from the volcanic arc must have crossed the rising CFB in order to be deposited in the Karoo basin. The most likely sediment pathways connecting the volcanic arc to the Karoo basin are the Ceres syntaxis and Port Elizabeth antitaxis (Fig. 67). Due to the proximity of the North Patagonian Massif and Deseado massif to the Ceres syntaxis and Port Elizabeth antitaxis and proposed paleocurrent direction, it is likely that sediment from these source terranes are present in the Karoo basin (Fig. 67). It is also likely that sediment from the Cape Supergroup and Namaqua-Natal metamorphic supply sediment to Karoo basin-fill (Fig. 68). 


\section{Mid-Late Permian}

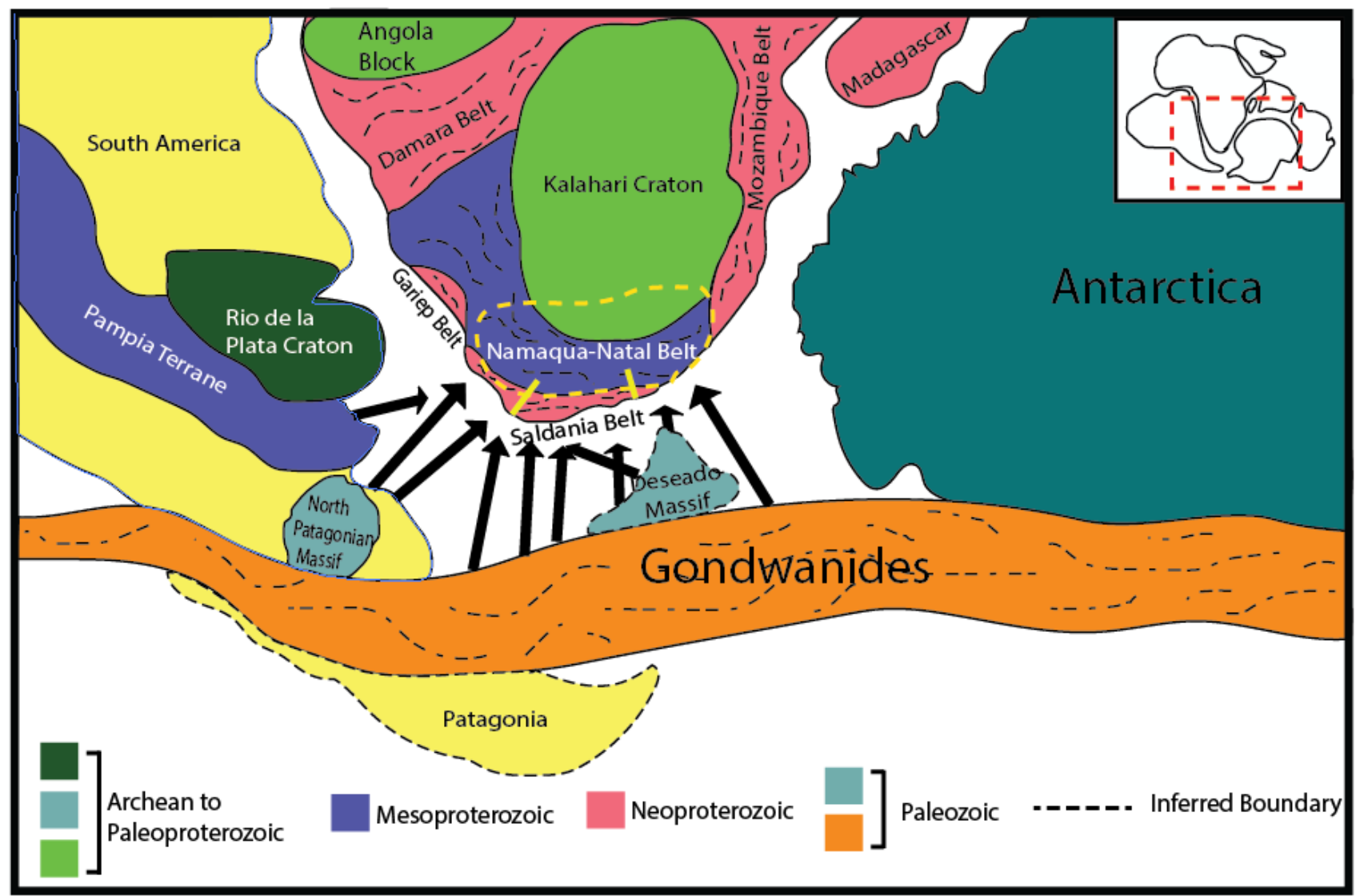

Figure 67: Sketch map of southern Gondwanna displaying the approximate location of the Karoo basin (yellow dashed line) with respect to surrounding source areas during the Mid-Late Permian. The black arrows indicate detrital input from various aged source terranes for the Ecca and Beaufort Groups. The solid yellow lines represent the Ceres syntaxis and Port Elizabeth antitaxis. It is also likely that sources to the north may input detritus into the Karoo basin. Also, note the likely position of the North Patagonian Massif and Deseado Massif to the south of southern Africa [Modified from Pankhurst et al., 2006; Rapela et al., 2011; Uriz et al., 2011; Veevers and Saeed 2013; and Vorster 2013]. 


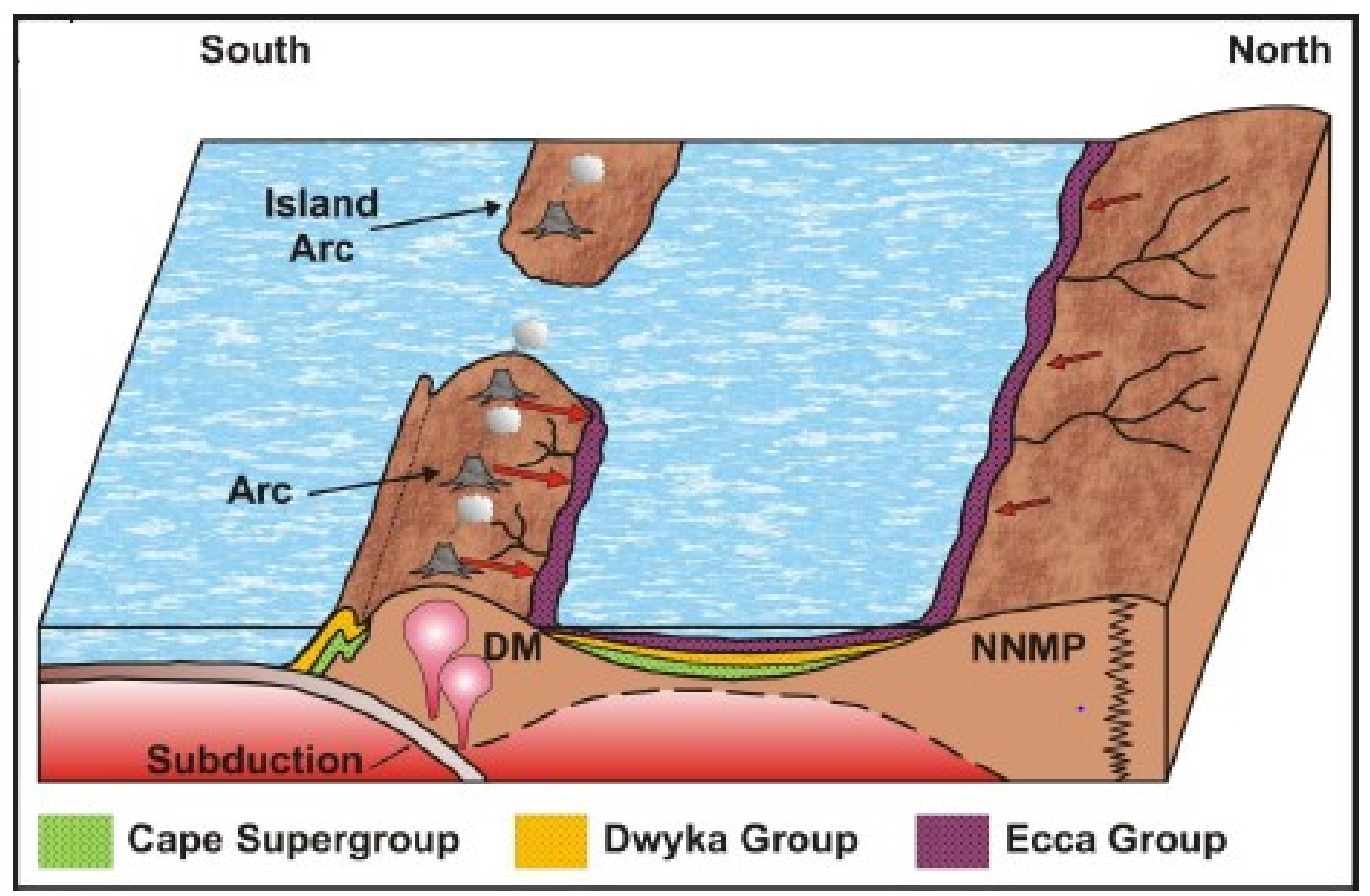

Figure 68: Schematic representation of the deposition of the Ecca Group during the Early to Late Permian. From Vorster (2013). DM= Deseado Massif, NNMP= Namanqua-Natal metamorphic provence.

\section{Chapter V: Conclusions}

1. U-Pb analysis of 553 detrital zircon grains from seven samples provide ages that are coeval with multiple potential source terranes and tectonic events. These include the Gondwanide Orogeny (235-290 Ma), North Patagonian Massif (235-580 Ma), Cape Fold Belt (350-2700 Ma), Deseado Massif (344-521 Ma), Dwyka Glacial deposits (500- 3500 Ma), Pampean Orogeny (384 Ma: post orogenic granites; 525-550 Ma: orogenic event), Pan African Orogeny (488-1100 Ma) and associated terranes (Table 2), The NamaquaNatal Orogeny (1000-2100 Ma) and the Kaapvaal Craton (>1800 Ma). The U-Pb age distributions of the events and source terranes allowed for the determination of provenance of the Ecca and Beaufort groups within the Karoo basin.

2. The prominent Permian-Triassic age population (235-290 Ma) within the Ecca and 
Beaufort groups was likely derived from a southern magmatic arc positioned to the south of Gondwanna. Airfall ash deposits present in the lower Ecca and Dwyka Group is evidence that the arc may have existed. U-Pb age $\mathrm{Vs} \mathrm{U} / \mathrm{Th}$ ratio plots also indicates that juvenile zircons were derived from a magmatic source.

3. Previous studies conducted within the Karoo basin have established that the north to northeasterly paleocurrent data acquired from the Ecca and lower Beaufort Groups indicates that sediment from source terranes located to the south of Gondwanna likely entered the Karoo basin through the Ceres syntaxis and Port Elizabeth antitaxis. Although the Ceres syntaxis presents as a structural high, the Ceres syntaxis is likely topographically inverted allowing sediment to flow from southwest to northeast.

4. The Neoproterozoic to Devonian age population (359-1000 Ma) present in Karoo basinfill was likely derived from the Cape Supergroup and rocks that source the Cape Supergroup as well as the Cape Granite Suite and Dwyka Group. The Deseado Massif may also contribute grains to Karoo basin-fill given its proposed position during the Permian and presence of the Port Elizabeth antitaxis. The north/northeast paleocurrent indicators present in Permian strata support this hypothesis.

5. Due to the north to northeasterly paleocurrent direction, source terranes surrounding the margins of the Kaapvaal Craton (Gariep Belt, Namaqua-Natal metamorphic provence, Damara Belt, and Mozambique Belt) can be ruled out as primary sediment sources for Karoo basin-fill. Although grains from these source terranes appear in Karoo basin- fill, they are likely derived from the Cape Supergroup and Dwyka Group which already contained significant amounts of grains from these source terranes. Therefore, the likely primary sediment sources for Karoo basin fill $>300 \mathrm{Ma}$ are the Cape Supergroup 
and the Dwyka Group as well as the Cape Granite Suite which may also supply sediment to the Karoo basin as well.

6. The Cape Fold Belt was likely subaerial during the deposition of Karoo basin-fill based on the ${ }^{40} \mathrm{Ar} /{ }^{39} \mathrm{Ar}$ data and abundance of detrital zircons $>300$ Ma that were probably eroded from the Cape Supergroup (or Dwyka Group). The presence of a NorthNortheasterly paleocurrent direction during the Permian supports this hypothesis.

7. Detrital zircon samples collected within the Ecca and Beaufort Groups contain relatively uniform age populations with only slight variations in grain contributions in the Tanqua, Laingsburg, and Ripon sub-basins. Since there are no significant increases in any one age population or presence of ambiguous age populations in samples collected across the Karoo basin it is likely that there are no additional source areas supplying sediment to Karoo basin-fill (Ecca and Beaufort Groups).

8. Point counting of 18 thin-sections from separate sandstone samples within the Tanqua, Laingsburg, and Ripon sub-basins determined that all samples either plot as lithic arkose or feldspathic litharenite. Beaufort Group samples tend to have slightly more quartz than samples from lower in the stratigraphy (middle to upper Ecca Group).

9. Determining provenance from thin-section petrography is difficult because multiple source locations with differing lithologies (magmatic arc, CFB, Cape Granite, and Dwyka Group) likely supply sediment into the Karoo basin simultaneously causing a mixing effect. All samples plot within the mixed and dissected arc fields on QmFLt diagrams.

10. Heavy mineral assemblages are relatively uniform with slightly varying amounts of neosilicates and phyllosilicates. Determining provenance from heavy minerals was difficult due to the non-uniqueness in abundant heavy mineral assemblages. Abundant 
heavy mineral assemblages tend to be common minerals in most surrounding source locations including two-mica granites, quartzite, and magmatic arc terranes. 


\section{References}

Adelmann, D., \& Fiedler, K. (1998). Origin and characteristics of Late Permian submarine fan and deltaic sediments in the Laingsburg subbasin (SW Karoo Basin, Cape Province/South Africa). Zeitschrift Deutsche Geologische Gesellschaft, 149, 27-38.

Andersson, P. O. D., Johansson, Å., \& Kumpulainen, R. A. (2003). Sm-Nd isotope evidence for the provenance of the Skoorsteenberg Formation, Karoo Supergroup, South Africa. Journal of African Earth Sciences, 36(3), 173-183.

Andersson, P. O. D., Worden, R. H., Hodgson, D. M., \& Flint, S. (2004). Provenance evolution and chemostratigraphy of a Palaeozoic submarine fan-complex: Tanqua Karoo Basin, South Africa. Marine and Petroleum Geology,21(5), 555-577.

Andersen, T. (2005). Detrital zircons as tracers of sedimentary provenance: limiting conditions from statistics and numerical simulation. Chemical Geology,216(3), 249270.

Armstrong, Frank, C., and Boudette, Eugene, L. (1984). Two-mica grainites: Part A their occurrence and petrography. U-S geological Survey, 84-173.

Beaumont, C. (1981), Foreland basins, Geophysical Journal of the Royal Astronomical Society, 65, 291-329.

Black, L. P., Kamo, S. L., Allen, C. M., Davis, D. W., Aleinikoff, J. N., Valley, J. W., ... \& Foudoulis, C. (2004). Improved $206 \mathrm{~Pb} / 238 \mathrm{U}$ microprobe geochronology by the monitoring of a trace-element-related matrix effect; SHRIMP, ID-TIMS, ELA-ICPMS and oxygen isotope documentation for a series of zircon standards. Chemical Geology, 205(1-2), 115-140.

Booth, P.W.K. (2011), A review of the structural geology of the Cape Fold Belt and challenges towards future research, South African Journal of Geology, 114, 3-4, 235248.

Brezinski, D. K. (1989). Geology of the Sideling Hill road cut. Maryland Geological Survey.

Broquet, C. A. (1992). The sedimentary record of the Cape Supergroup: A review. Inversion tectonics of the Cape Fold Belt, Karoo and Cretaceous basins of southern Africa, 159-183.

Busby, C., \& Ingersoll, R. V. (1995). Tectonics of sedimentary basins. Blackwell Science.

Catuneanu, O., Hancox, P. J., \& Rubidge, B. S. (1998). Reciprocal flexural behaviour and contrasting stratigraphies: a new basin development model for the Karoo retroarc foreland system, South Africa. Basin Research, 10(4), 417-439.

Catuneanu, O. and Elango, H. N. (2001). Tectonic control on fluvial styles: the Balfour 
Formation of the Karoo Basin, South Africa. Sedimentary Geology, 140, 291-313

Catuneanu, O., Hancox, P. J., Cairncross, B., \& Rubidge, B. S. (2002). Foredeep submarine fans and forebulge deltas: orogenic off-loading in the underfilled Karoo Basin. Journal of African Earth Sciences, 35(4), 489-502.

Catuneanu, O. Wopfner, H., Eriksson, P.G., Cairncross, B., Rubidge, B.S., Smith, R.M.H., Hancox, P.J. (2005), The Karoo basins of south-central Africa, Journal of African Earth Sciences, 43, 211-253.

Cole, D. I. (1992). Evolution and development of the Karoo Basin. Inversion tectonics of the Cape Fold Belt, Karoo and cretaceous basins of Southern Africa, 87-99.

Craddock, J., \& Thomas, R. (2011). Detrital zircon provenance ages of the "Dwyka Tillite" in South Africa and the Falkland Islands.

Da Silva, L. C., Gresse, P. G., Scheepers, R., McNaughton, N. J., Hartmann, L. A., \& Fletcher, I. (2000), U-Pb SHRIMP and Sm-Nd age constraints on the timing and sources of the Pan-African Cape Granite Suite, South Africa.Journal of African Earth Sciences, 30(4), 795-815.

De Beer, C.H. (1990), Simultaneous folding in the western and southern branches of the Cape Fold Belt, South African Journal of Geology, 93, 583-591.

De Wit, M. J., de Ronde, C. E., Tredoux, M., Roering, C., Hart, R. J., Armstrong, R. A., Hart, R. A. (1992), Formation of an Archaean continent. Nature, 357(6379), 553562.

De Wit, M. J., \& Ransome, I. G. (1992). Regional inversion tectonics along the southern margin of Gondwana. Inversion tectonics of the Cape Fold Belt, Karoo and Cretaceous basins of southern Africa, 15-21.

Dean, J. (2012), A Multi-Method Approach to Reconstruct the Thermal History of the Karoo Basin, South Africa, AAPG Abstract Rocky Mountain Rendezvous.

Dickinson, W. R. (1985). Interpreting provenance relations from detrital modes of sandstones. In Provenance of arenites (pp. 333-361). Springer Netherlands.

Dickinson, W. R., \& Suczek, C. A. (1979). Plate tectonics and sandstone compositions. AAPG Bulletin, 63(12), 2164-2182.

Dickinson, W. R., \& Gehrels, G. E. (2009). Use of U-Pb ages of detrital zircons to infer maximum depositional ages of strata: a test against a Colorado Plateau Mesozoic database. Earth and Planetary Science Letters, 288(1), 115-125.

Du Toit, A. L. (1937), Our Wandering Continents: an hypothesis of continental drifting. Oliver 
and Boyd.

Eglington, B. M. (2006). Evolution of the Namaqua-Natal Belt, southern Africa-A geochronological and isotope geochemical review. Journal of African Earth Sciences, 46(1), 93-111.

Elliot, D.H., Watts, D.R., (1974). The nature and origin of volcanoclastic material in some Karoo and Beacon rocks. Trans. Geol. Soc. S. Afr. 77, 109-111.

Elliot, D.H., Johnson, M., (1972). The Gondwanide orogeny: new data from South Africa and the problem of the Falkland Island. Abstr. Progm., Geol. Soc. Amer. 4, 498-499.

Faure, K., Armstrong, R. A., Harris, C., \& Willis, J. P. (1996). Provenance of mudstones in the Karoo Supergroup of the Ellisras basin, South Africa: geochemical evidence. Journal of African Earth Sciences, 23(2), 189-204.

Faure, K., And Cole, D., (1999), Geochemical evidence for lacustrine microbial blooms in the vast Permian Main Karoo, Parana, Falkland Islands and Huab basins of southwestern Gondwana: Palaeogeography, Palaeoclimatology, Palaeoecology, 152, 189-213.

Fildani, A., Drinkwater, N.J., Weislogel, A., McHargue, T., Hodgson, D.M., Flint, S. (2007), Age controls on the Tanqua and Laingsburg deep-water systems: New insights on the evolution and sedimentary fill of the Karoo Basin, South Africa, Journal of Sedimentary Research, 77, 901-908.

Fildani, A., Weislogel, A., Drinkwater, N.J., McHargue, T., Tankard, T., Wooden, J., Hodgson, D., Flint, S. (2009), U-Pb zircon ages from the southwestern Karoo Basin, South Africa Implications for the Permian-Triassic boundary, Geology, 37, 719-722.

Folk, R. L., (1980), Petrology of Sedimentary Rocks: Austin, Hamilton Publishing, p 184.

Fourie, P. H., Zimmermann, U., Beukes, N. J., Naidoo, T., Kobayashi, K., Kosler, J., Nakamura, E., Tait, J., Theron, J. N. (2010), Provenance and reconnaissance study of detrital zircons of the Palaeozoic Cape Supergroup in South Africa: revealing the interaction of the Kalahari and Río de la Plata cratons. International Journal of Earth Sciences, 100(2-3), 527-541.

Frimmel, H. E., Hartnady, C. J., \& Koller, F. (1996). Geochemistry and tectonic setting of magmatic units in the Pan-African Gariep Belt, Namibia. Chemical Geology, $130(1), 101-121$.

Gehrels, G., V. Valencia, and A. Pullen, (2006), NoDetrital Zircon Geochronology by Laser Ablation Multicollector ICPMS at the Arizona LaserChron Center, in T. Olszewski, ed., Geochronology: Emerging Opportunities: Paleontology Society Papers, 67-76.

Gehrels, G. E., Valencia, V. A., \& Ruiz, J. (2008). Enhanced precision, accuracy, efficiency, and spatial resolution of $\mathrm{U}-\mathrm{Pb}$ ages by laser ablation-multicollector-inductively coupled 
plasma-mass spectrometry. Geochemistry, Geophysics, Geosystems, 9(3).

Grecula, M. (2000). Stratigraphy and architecture of tectonically controlled turbidite systems: Laingsburg Formation, Karoo Basin, South Africa. Ph.D. thesis, University of Liverpool, United Kingdom, 291 p.

Grecula, M., Flint, S., Potts, G., Wickens, D., \& Johnson, S. (2003a). Partial ponding of turbidite systems in a basin with subtle growth-fold topography: Laingsburg-Karoo, South Africa. Journal of Sedimentary Research, 73(4), 603-620.

Grecula, M., Flint, S.S., Wickens, H.Dev., and Johnson, S.D., (2003b), Upward thickening patterns and lateral continuity of Permian sand-rich turbidite channel fills, Laingsburg Karoo, South Africa: Sedimentology, v. 50, p. 831-853.

Gresse, P. G., Von Veh, M. W., \& Frimmel, H. E. (2006). Namibian (Neoproterozoic) to early Cambrian successions. The geology of South Africa, 395-420.

Halbich, I.W., (1983). Geodynamics of the Cape Fold Belt in the Republic of South Africa, a summary. In: Rast, N., Delaney, F.M. (Eds.), Profiles of orogenic belts. Geodynamics series 10, 21-29. Am. Geophys. Union, Washington, DC.

Hälbich, I.W., Fitch, F.J., Miller, J.A. (1983), Dating the Cape Orogeny, Special Publication of the Geological Society of South Africa, 12, 149-164.

Hambrey, M. J., \& Harland, W. B. (Eds.). (2011). Earth's pre-Pleistocene glacial record. Cambridge University Press.

Hodgson, D.M., Flint, S.S., Hodgetts, D., Drinkwater, N.J., Johannesson, E.J., and Luthi, S.M., (2006), Stratigraphic evolution of Permian submarine fan systems, Tanqua depocenter, South Africa: Journal of Sedimentary Research, 76, 19-39.

Hoskin, P. W., \& Ireland, T. R. (2000). Rare earth element chemistry of zircon and its use as a provenance indicator. Geology, 28(7), 627-630.

Hoskin, P. W. O., and U. Schaltegger, (2003), The Composition of Zircon and Igneous and Metamorphic Petrogenesis, in J. M. Hancher, and P. W. . Hoskin, eds., Zircon Reviews in Mineralogy and Geochemistry, 27-62.

Ingersoll, R. V., Fullard, T. F., Ford, R. L., Grimm, J. P., Pickle, J. D., \& Sares, S. W. (1984). The effect of grain size on detrital modes; a test of the Gazzi-Dickinson point-counting method. Journal of Sedimentary Research, 54(1), 103-116.

Jahn, B. M., \& Condie, K. C. (1995). Evolution of the Kaapvaal Craton as viewed from Geochemical and Sm-Nd isotopic analyses of intracratonic pelites. Geochimica et Cosmochimica Acta, 59(11), 2239-2258. 
Johnson, M. R. (1976). Stratigraphy and sedimentology of the Cape and Karoo sequences in the Eastern Cape Province (Doctoral dissertation, Rhodes University).

Johnson, M. R. (1991). Sandstone petrography, provenance and plate tectonic setting in Gondwana context of the southeastern Cape-Karoo Basin. South African Journal of Geology, 94(2-3), 137-154.

Johnson, M.R. and Kingsley, C.S., (1993). Lithostratigraphy of the Ripon Formation (Ecca Group), including the Pluto's Vale, Wonderfontein and Trumpeters Members. Lithostrat. Ser. S. Afr. Comm. Strat., 26.

Johnson, M. R., Van Vuuren, C. J., Hegenberger, W. F., Key, R., \& Show, U. (1996). Stratigraphy of the Karoo Supergroup in southern Africa: an overview.Journal of African Earth Sciences, 23(1), 3-15.

Johnson, M. R., Vuuren, C. V., Visser, J. N. J., Cole, D. I., Wickens, H. D. V., Christie, A. D. M., \& Roberts, D. L. (1997), The Foreland Karoo basin, South Africa. Sedimentary basins of the world, 3, 269-317.

Johnson, M.R., van Vuuren C.J., Visser, J.N.J., Cole, D.I., Wickens H. de V., Christie, A.D.M., Roberts, D.L and Brandl, G. (2006). Sedimentary Rocks of the Karoo Supergroup, 461-499. In: Johnson,M.R., Anhaeusser, C.R. and Thomas, R.L. (Eds.), The Geology of South Africa. Geological Society of South Africa, Johannesberg/Council for Geoscience, Pretoria.

Johnson, S. D., Flint, S., Hinds, D., \& De Ville Wickens, H. (2001). Anatomy, geometry and sequence stratigraphy of basin floor to slope turbidite systems, Tanqua Karoo, South Africa. Sedimentology, 48(5), 987-1023.

Johnston, S. T. (2000). The Cape Fold Belt and Syntaxis and the rotated Falkland Islands: dextral transpressional tectonics along the southwest margin of Gondwana. Journal of African Earth Sciences, 31.1, 51-63.

Katemaunzanga, D., \& Gunter, C. J. (2009). Lithostratigraphy, Sedimentology, and Provenance of the Balfour Formation (Beaufort Group) in the Fort Beaufort-Alice Area, Eastern Cape Province, South Africa.Acta Geologica Sinica-English Edition, 83(5), 902-916.

King, R., Van Lente, B., Potts, G., Hodgson, D.M., Anderson, P.O.D., Worden, R.H., Flint, S.S. \& Wickens, H. Dev. (2004). Extra-foreland source to turbidites sink in the early Karoo basin, South Africa. AAPG Annual meeting 2004: Embrace the Future, Celbrate the Past Technical Program. (Poster)

King, R.C., (2005), Structural evolution of the Cape Fold Belt: implications for sediment routing to the SW Karoo Basin [unpublished Ph.D. thesis]: University of Liverpool, 327. 
Kingsley, C.S., (1981). A composite submarine fan-delta-fluvial model for the Ecca and lower Beaufort groups of Permian age in the Eastern Cape Province, South Africa. Trans. Geol. Soc. S. Afr. 84, 27-40.

Kisters, A. F., Belcher, R. W., Scheepers, R., Rozendaal, A., Jordaan, L. S., \& Armstrong, R. A. (2002). Timing and kinematics of the Colenso Fault: The Early Paleozoic shift from collisional to extensional tectonics in the Pan-African Saldania Belt, South Africa. South African Journal of Geology, 105(3), 257-270.

Kröner, A., \& Stern, R. J. (2004). Africa: Pan-African Orogeny. Encyclopedia of Geology. Elsevier, 1-12.

Live ALC Web Page. (n.d.). Live ALC Web Page. Retrieved July 1, 2014, from http://www.laserchron.org

Lisi, A. (2013), Provenance of the Upper Jurassic Norphlet and Surrounding Formations from U-Pb Detrital Zircon Geochronology (Thesis Dissertation: West Virginia University).

Lock, B.E., (1980). Flat-plate subduction and the Cape Fold Belt of South Africa. Geology 8, 35-39.

López-Gamundí, O. R., \& Rossello, E. A. (1998). Basin fill evolution and paleotectonic patterns along the Samfrau geosyncline: the Sauce Grande basin-Ventana foldbelt (Argentina) and Karoo basin-Cape foldbelt (South Africa) revisited. Geologische Rundschau, 86(4), 819-834.

Lopez-Gamundí, O. (2006), Permian plate margin volcanism and tuffs in adjacent basins of west Gondwana: Age constraints and common characteristics, Journal of South American Earth Sciences, 22, 227-238.

Ludwig KR \& Mundil R (2002), Geochimica et Cosmochimica Acta, 66 Supplement 1463.

Ludwig, K. R., (2012), A Geochronological Toolkit for Microsoft Excel, Berkeley Geochronology Center Special Publication, 5, 75.

Mange, M. A., \& Maurer, H. F. (1992). Heavy minerals in colour (Vol. 147, p. 145). London: Chapman \& Hall.

Martini, J.E.J., (1974). On the presence of ash beds and volcanic fragments in the graywackes of the Karoo system in the southern Cape Province (South Africa). Trans. Geol. Soc. S. Afr. 77, 113-116.

McCarthy, T. \&, Rubridge, B. (2005). The Story of Earth and Life. Struik p. 161, 187- 195.

McCourt, S., Armstrong, R. A., Grantham, G. H., \& Thomas, R. J. (2006). Geology and 
evolution of the Natal belt, South Africa. Journal of African Earth Sciences, 46(1), 71-92.

McKay, M., Weislogel, A. L., Dean, J., and Fildani, A. (2012), Integrating Burial History and Isostatic Models to Evaluate Tectonic Subsidence Models: Karoo Basin, South Africa. In 2012 GSA Annual Meeting in Charlotte.(Poster)

McKay, M., Dean, J., and Weislogel, A. (2013), The Impact of High Precision Age Controls in Basin Modeling for Tectonic Studies: Karoo Basin, South Africa, AAPG ACE Abstract.

McKay, M.P., Weislogel, A.L., Fildani, A., Brunt, R.L., Hodgson, D.M., Flint, S.S. (in review), $\mathrm{U}-\mathrm{Pb}$ zircon ash geochronology from the Karoo Basin, South Africa: Implications of zircon recycling for the marine and terrestrial Permian-Triassic boundary, American Journal of Science.

Meert, J.G. (2003), A synopsis of events related to the assembly of eastern Gondwana. Tectonophysics 362: 1-40.

Moreira, P., Fernández, R., Hervé, F., Fanning, C. M., \& Schalamuk, I. A. (2013). Detrital zircons U-Pb SHRIMP ages and provenance of La Modesta Formation, Patagonia Argentina. Journal of South American Earth Sciences,47, 32-46.

Mve, N. (2005), Petrology, geochronology and provenance of the Laingsburg and Tanqua Karoo submarine fan systems, Ecca Group, South Africa (Masters dissertation, Stellenbosch: University of Stellenbosch).

Pankhurst, R. J., Rapela, C. W., Loske, W. P., Márquez, M., \& Fanning, C. M. (2003). Chronological study of the pre-Permian basement rocks of southern Patagonia. Journal of South American Earth Sciences, 16(1), 27-44.

Pankhurst, R. J., Rapela, C. W., Fanning, C. M., \& Márquez, M. (2006). Gondwanide continental collision and the origin of Patagonia. Earth-Science Reviews, 76(3), 235257.

Paton, C., Woodhead, J. D., Hellstrom, J. C., Hergt, J. M., Greig, A., \& Maas, R. (2010). Improved laser ablation $\mathrm{U}-\mathrm{Pb}$ zircon geochronology through robust downhole fractionation correction. Geochemistry, Geophysics, Geosystems,11(3).

Press WH, Flannery BP, Teukolsky SA Vetterling WT (1986) Numerical Recipes: The Art of Scientific Computing. Cambridge University Press, Cambridge, UK, 818.

Priestley, K., McKenzie, D., \& Debayle, E. (2006). The state of the upper mantle beneath southern Africa. Tectonophysics, 416(1), 101-112.

Rapela, C. W., Pankhurst, R. J., Casquet, C., Fanning, C. M., Baldo, E. G., González-Casado, 
J. M., Galindo, C., and Dahlquist, J. (2007). The Río de la Plata craton and the assembly of SW Gondwana. Earth-Science Reviews, 83(1), 49-82.

Rapela, C. W., Fanning, C. M., Casquet, C., Pankhurst, R. J., Spalletti, L., Poiré, D., \& Baldo, E. G. (2011). The Rio de la Plata craton and the adjoining PanAfrican/brasiliano terranes: their origins and incorporation into south-west Gondwana. Gondwana research, 20(4), 673-690.

Romer, R.L. 2003. Alpha-recoil in U-Pb geochronology: Effective sample size matters. Contributions to Mineralogy and Petrology 145, (4): 481-491.

Rozendaal, A., Gresse, P. G., Scheepers, R., \& Le Roux, J. P. (1999). Neoproterozoic to early Cambrian crustal evolution of the Pan-African Saldania belt, South Africa. Precambrian research, 97(3), 303-323.

Rubidge, B.S., 1991, A new primitive dinocephalian mammal-like reptile from the Permian of southern Africa: Palaeontology, v. 34, p. 547-559.

Rubidge, B.S., Modesto, S., Sidor, C. and Welman, J. (1999). Eunotosaurus afticanus from the Ecca-Beaufort contact in the Northern Cape - implications for Karoo Basin development. S. Aft J. Sci., 95, 553-555.

Rubidge, B.S., Hancox, P.J., Catuneanu, O. (2000), Sequence analysis of the Ecca- Beaufort contact in the southern Karoo of South Africa, South African Journal of Geology, $103,81-96$.

Scheepers R. and Armstrong R., (2002), New U-Pb SHRIMP zircon ages of the Cape Granite Suite: implications for the magmatic evolution of the Saldania Belt. South African Journal of Geology 105:241-256

Shone, R. W., \& Booth, P. W. K. (2005). The Cape Basin, South Africa: A review. Journal of African Earth Sciences, 43(1), 196-210.

Sixsmith, P., Flint, S.S., Wickens, H.Dev., and Johnson, S.D., (2004), Anatomy and stratigraphic development of a basin floor turbidite system in the Laingsburg Formation, main Karoo Basin, South Africa: Journal of Sedimentary Research, 74, 239-254.

Sláma, J., Košler, J., Condon, D. J., Crowley, J. L., Gerdes, A., Hanchar, J. M., ... \& Whitehouse, M. J. (2008). Plešovice zircon - a new natural reference material for U$\mathrm{Pb}$ and $\mathrm{Hf}$ isotopic microanalysis. Chemical Geology, 249(1), 1-35.

Smithies, R. H. (1992). The geochemical evolution of three alkaline complexes in the KuboosBremen igneous province, southern Namibia (Doctoral dissertation, Rhodes University). 
Steno, N. (1669), De Solido Intra Solidum Naturaliter Contento Dissertationis Prodromus, Florence, reprinted in Memoirs of the American Academy in Rome Volume II (1918), pp.181-227.

Tankard, Anthony, Herman Welsink, Peter Aukes, Robert Newton, and Edgar Stettler. (2009), Tectonic Evolution of the Cape and Karoo Basins of South Africa. Marine and Petroleum Geology 26.8, 1379-412.

Thamm, A.G., Johnson, M.R., (2006). The Cape Supergroup. In: Johnson, M.R., Anhaeusser, C.R., Thomas, R.J. (Eds.), The Geology of South Africa. Geological Society of South Africa and Council for Geoscience,. 443-460.

Thomson, K. (1998). When did the Falklands rotate?. Marine and petroleum geology, 15(8), 723-736.

Turner, B. R. (1999). Tectonostratigraphical development of the Upper Karooforeland basin: Orogenic unloading versus thermally-induced Gondwana rifting. Journal of African Earth Sciences, 28(1), 215-238.

Uriz, N. J., Cingolani, C. A., Chemale Jr, F., Macambira, M. B., \& Armstrong, R. (2011). Isotopic studies on detrital zircons of Silurian-Devonian siliciclastic sequences from Argentinean North Patagonia and Sierra de la Ventana regions: comparative provenance. International Journal of Earth Sciences, 100(2-3), 571-589.

Van Vuuren, C.J., Cole, D.I., (1979). The stratigraphy and depositional environments of the Ecca Group in the northern part of the Karoo Basin. Geological Society of South Africa Special Publication 6, 103-111.

Van der Plas, L., \& Tobi, A. C. (1965). A chart for judging the reliability of point counting results. American Journal of Science, 263(1), 87-90.

Van Lente, B., (2004), Chemostratigraphic trends and provenance of the Permian Tanqua and Laingsburg depocentres, South Western Karoo Basin, South Africa [unpublished Ph.D. thesis]: University of Stellenbosch, 339 p.

Veevers, J.J., Cole, D.I., Cowan, E.J. (1994), Southern Africa: Karoo basin and Cape fold belt, in Veevers, J.J., Powell, C.McA. (eds.), Permian-Triassic Pangean Basins and Foldbelts along the Panthalassan Margin of Gondwanaland, Geological Society of America Memoir, 184, 223-279.

Veevers, J. J., \& Saeed, A. (2013). Age and composition of Antarctic sub-glacial bedrock reflected by detrital zircons, erratics, and recycled microfossils in the Ellsworth LandAntarctic Peninsula-Weddell Sea-Dronning Maud Land sector (240 E-0-015 E). Gondwana Research, 23(1), 296-332.

Vermeesch, P. (2004). How many grains are needed for a provenance study?.Earth and 
Planetary Science Letters, 224(3), 441-451.

Vermeesch, P. (2012). On the visualisation of detrital age distributions.Chemical Geology, 312, 190-194.

Visser, J.N.J., (1979). Changes in sediment transport direction in the Cape-Karroo Basin (Silurian-Triassic) in South Africa. S. Afr. J. Sci. 75, 72-75.

Visser, J. N. J., Hall, K. J., \& Loock, J. C. (1986). The application of stone counts in the glacigene Permo-Carboniferous Dwyka Formation, South Africa.Sedimentary geology, 46(3), 197-212.

Visser, J.N.J., (1993), Sea-level changes in a back-arc foreland transition-the Late Carboniferous-Permian Karoo Basin of South Africa: Sedimentary Geology, 83, 115131.

Visser, J. N. (1996). Controls on Early Permian shelf deglaciation in the Karoo Basin of South Africa. Palaeogeography, Palaeoclimatology, Palaeoecology,125(1), 129- 139.

Vorster, C. (2013). Laser ablation ICP-MS age determination of detrital zircon populations in the Phanerozoic Cape and Lower Karoo Supergroups (South Africa) and correlatives in Argentina (Doctoral dissertation).

Wickens, H.deV., 1992. Submarine fans of the Permian Ecca Group in the SW Karoo basin: their origin and reflection on the tectonic evolution of the basin and its source areas. In: de Wit, M.J., Ransome, I.G.D. (Eds.), Inversion Tectonics of the Cape Fold Belt, Karoo and Cretaceous Basins of Southern Africa. Balkema, Rotterdam, pp. 117-125.

Wickens, H. deV (1994). Basin floor fan building turbidites of the southwestern Karoo Basin, Permian Ecca Group, South Africa (Doctoral dissertation, University of Port Elizabeth).

Wickens, H. deV and Bouma, A. H. (2000), The Tanqua fan complex, Karoo Basin, South Africa-Outcrop analog for fine-grained, deepwater deposits, in A. H Bouma and C. G. Stone, eds., Fine-grained turbidite systems, AAPG Memoir 72/SEPM Special Publication No. 68, p. 153-164.

Weltje, G. J., \& von Eynatten, H. (2004). Quantitative provenance analysis of sediments: review and outlook. Sedimentary Geology, 171(1), 1-11.

Wild, R.J., 2005, Sedimentological and sequence stratigraphic evolution of a Permian lower slope to shelf succession, Tanqua Depocentre, SW Karoo Basin, South Africa [unpublished Ph.D. thesis]: University of Liverpool, 368.

Whittle-Herbert, (1990) Deformation Structures in the Table Mountain Group centered on Vogelgat Nature Reserve, Hermanus. 


\section{Appendix A: U-Pb Detrital Zircon Isotopic Analysis}

\section{Appendices}

\begin{tabular}{|c|c|c|c|c|c|c|c|c|c|c|c|c|c|c|c|c|c|c|c|}
\hline Sample & $(\mathrm{ppm})$ & $204 \mathrm{~Pb}$ & & $207 \mathrm{~Pb}^{*}$ & $(\%)$ & $235 \mathrm{U}^{*}$ & $(\%)$ & $238 \mathrm{U}$ & $(\%)$ & corr. & $238 \mathrm{U}^{*}$ & (Ma) & $235 \mathrm{U}$ & (Ma) & $207 \mathrm{~Pb}^{*}$ & (Ma) & (Ma) & (Ma) & $(\%)$ \\
\hline & $\mathrm{U}$ & $206 \mathrm{~Pb}$ & $\mathrm{U} / \mathrm{Th}$ & $206 \mathrm{~Pb}^{*}$ & \pm & $207 \mathrm{~Pb}^{*}$ & \pm & $206 \mathrm{~Pb}^{*}$ & \pm & error & $206 \mathrm{~Pb}^{*}$ & \pm & $207 \mathrm{~Pb}^{*}$ & \pm & $206 \mathrm{~Pb}^{*}$ & \pm & $\begin{array}{c}\text { Best } \\
\text { age }\end{array}$ & \pm & Conc \\
\hline $\begin{array}{l}\text { 12ZA13- } \\
22\end{array}$ & 225 & 1056 & 0.8 & 17.11 & 3.6 & 0.31 & 4.5 & 0.0388 & 2.7 & 0.60 & 245.4 & 6.5 & 276.2 & 10.9 & 546.6 & 78.9 & 245.4 & 7 & NA \\
\hline $\begin{array}{l}\text { 12ZA13- } \\
12\end{array}$ & 471 & 830 & 1.0 & 17.06 & 2.8 & 0.32 & 3.6 & 0.0391 & 2.3 & 0.64 & 247.4 & 5.6 & 279.0 & 8.8 & 553.5 & 60.7 & 247.4 & 6 & NA \\
\hline $\begin{array}{l}\text { 12ZA13- } \\
10\end{array}$ & 447 & 2490 & 1.1 & 18.15 & 6.2 & 0.31 & 7.4 & 0.0409 & 4.1 & 0.55 & 258.2 & 10.3 & 274.5 & 17.8 & 416.4 & 138.0 & 258.2 & 10 & NA \\
\hline $\begin{array}{l}\text { 12ZA13- } \\
61\end{array}$ & 82 & 11325 & 0.9 & 19.31 & 13.2 & 0.30 & 15.0 & 0.0416 & 7.0 & 0.47 & 263.0 & 18.0 & 264.4 & 34.8 & 276.1 & 304.1 & 263.0 & 18 & NA \\
\hline $\begin{array}{l}\text { 12ZA13- } \\
18\end{array}$ & 519 & 2449 & 0.8 & 18.60 & 3.2 & 0.31 & 3.6 & 0.0417 & 1.5 & 0.43 & 263.6 & 4.0 & 273.8 & 8.5 & 361.7 & 72.2 & 263.6 & 4 & NA \\
\hline $\begin{array}{l}\text { 12ZA13- } \\
21\end{array}$ & 497 & 62134 & 1.0 & 18.98 & 1.8 & 0.30 & 2.1 & 0.0418 & 1.2 & 0.55 & 263.7 & 3.0 & 269.0 & 5.0 & 315.4 & 40.7 & 263.7 & 3 & NA \\
\hline $\begin{array}{l}\text { 12ZA13- } \\
35\end{array}$ & 129 & 4045 & 0.9 & 19.01 & 8.5 & 0.30 & 8.9 & 0.0418 & 2.5 & 0.28 & 263.9 & 6.5 & 268.8 & 21.0 & 311.4 & 194.2 & 263.9 & 6 & NA \\
\hline $\begin{array}{l}\text { 12ZA13- } \\
42\end{array}$ & 160 & 627 & 0.8 & 16.12 & 8.3 & 0.36 & 10.5 & 0.0423 & 6.4 & 0.61 & 267.3 & 16.7 & 313.8 & 28.3 & 675.5 & 178.1 & 267.3 & 17 & NA \\
\hline $\begin{array}{l}\text { 12ZA13- } \\
69\end{array}$ & 391 & 2791 & 0.8 & 18.52 & 3.7 & 0.32 & 3.9 & 0.0425 & 1.0 & 0.26 & 268.1 & 2.7 & 278.9 & 9.5 & 370.3 & 84.3 & 268.1 & 3 & NA \\
\hline $\begin{array}{l}\text { 12ZA13- } \\
59\end{array}$ & 289 & 1485 & 0.7 & 17.40 & 12.7 & 0.34 & 12.8 & 0.0425 & 1.9 & 0.15 & 268.5 & 5.1 & 295.0 & 32.9 & 509.9 & 280.2 & 268.5 & 5 & NA \\
\hline $\begin{array}{l}\text { 12ZA13- } \\
30\end{array}$ & 134 & 10054 & 0.7 & 18.59 & 7.7 & 0.32 & 8.1 & 0.0429 & 2.5 & 0.31 & 271.1 & 6.6 & 280.8 & 19.8 & 362.8 & 172.8 & 271.1 & 7 & NA \\
\hline $\begin{array}{l}\text { 12ZA13- } \\
8\end{array}$ & 142 & 20190 & 1.0 & 18.18 & 9.4 & 0.33 & 10.0 & 0.0430 & 3.4 & 0.34 & 271.3 & 9.0 & 286.5 & 25.0 & 412.4 & 211.3 & 271.3 & 9 & NA \\
\hline $\begin{array}{l}\text { 12ZA13- } \\
16\end{array}$ & 418 & 13985 & 0.8 & 18.77 & 3.1 & 0.32 & 3.3 & 0.0431 & 0.9 & 0.27 & 271.8 & 2.3 & 279.0 & 7.9 & 340.3 & 71.0 & 271.8 & 2 & NA \\
\hline $\begin{array}{l}\text { 12ZA13- } \\
28\end{array}$ & 167 & 43370 & 0.8 & 19.25 & 5.1 & 0.31 & 5.3 & 0.0432 & 1.6 & 0.30 & 272.4 & 4.2 & 273.5 & 12.8 & 282.7 & 116.3 & 272.4 & 4 & NA \\
\hline $\begin{array}{l}\text { 12ZA13- } \\
57\end{array}$ & 479 & 61902 & 1.0 & 18.95 & 1.4 & 0.31 & 3.4 & 0.0432 & 3.1 & 0.91 & 272.7 & 8.2 & 277.5 & 8.2 & 318.4 & 31.5 & 272.7 & 8 & NA \\
\hline $\begin{array}{l}\text { 12ZA13- } \\
7\end{array}$ & 451 & 12236 & 0.9 & 19.19 & 1.9 & 0.31 & 2.9 & 0.0433 & 2.2 & 0.75 & 273.2 & 5.8 & 274.9 & 7.0 & 290.2 & 44.4 & 273.2 & 6 & NA \\
\hline $\begin{array}{l}\text { 12ZA13- } \\
66\end{array}$ & 260 & 18087 & 0.9 & 19.05 & 4.2 & 0.31 & 4.5 & 0.0434 & 1.6 & 0.35 & 273.6 & 4.3 & 277.1 & 11.0 & 306.5 & 96.7 & 273.6 & 4 & NA \\
\hline $\begin{array}{l}\text { 12ZA13- } \\
67\end{array}$ & 432 & 3839 & 0.9 & 18.68 & 1.4 & 0.32 & 2.7 & 0.0436 & 2.4 & 0.87 & 274.9 & 6.4 & 283.2 & 6.8 & 351.7 & 30.6 & 274.9 & 6 & NA \\
\hline $\begin{array}{l}\text { 12ZA13- } \\
54\end{array}$ & 338 & 34774 & 1.0 & 18.89 & 2.7 & 0.32 & 3.6 & 0.0436 & 2.3 & 0.64 & 275.0 & 6.1 & 280.4 & 8.7 & 326.2 & 62.3 & 275.0 & 6 & NA \\
\hline $\begin{array}{l}\text { 12ZA13- } \\
9\end{array}$ & 170 & 5998 & 0.7 & 18.87 & 5.9 & 0.32 & 6.7 & 0.0440 & 3.2 & 0.48 & 277.6 & 8.7 & 283.1 & 16.5 & 328.0 & 133.5 & 277.6 & 9 & NA \\
\hline $\begin{array}{l}\text { 12ZA13- } \\
23\end{array}$ & 377 & 55656 & 0.8 & 19.40 & 1.7 & 0.32 & 2.2 & 0.0445 & 1.3 & 0.61 & 280.8 & 3.7 & 279.2 & 5.4 & 265.6 & 40.0 & 280.8 & 4 & NA \\
\hline $\begin{array}{l}\text { 12ZA13- } \\
48\end{array}$ & 346 & 19472 & 1.1 & 18.84 & 2.3 & 0.33 & 2.7 & 0.0450 & 1.5 & 0.56 & 284.0 & 4.2 & 289.4 & 6.8 & 332.7 & 51.0 & 284.0 & 4 & NA \\
\hline $\begin{array}{l}\text { 12ZA13- } \\
65\end{array}$ & 204 & 25135 & 0.6 & 19.67 & 5.0 & 0.32 & 5.1 & 0.0452 & 1.1 & 0.21 & 284.7 & 2.9 & 279.3 & 12.5 & 234.1 & 116.0 & 284.7 & 3 & NA \\
\hline $\begin{array}{l}\text { 12ZA13- } \\
39\end{array}$ & 221 & 7430 & 0.8 & 17.69 & 11.1 & 0.35 & 11.5 & 0.0452 & 3.1 & 0.27 & 284.9 & 8.5 & 306.4 & 30.5 & 472.8 & 246.5 & 284.9 & 9 & NA \\
\hline $\begin{array}{l}\text { 12ZA13- } \\
20\end{array}$ & 416 & 11205 & 1.0 & 19.10 & 1.5 & 0.33 & 1.8 & 0.0460 & 1.0 & 0.57 & 289.8 & 2.9 & 291.1 & 4.5 & 301.4 & 33.1 & 289.8 & 3 & NA \\
\hline $\begin{array}{l}\text { 12ZA13- } \\
68\end{array}$ & 343 & 1452 & 1.3 & 17.21 & 12.0 & 0.38 & 12.0 & 0.0471 & 1.0 & 0.08 & 296.6 & 2.9 & 325.1 & 33.5 & 534.4 & 263.3 & 296.6 & 3 & NA \\
\hline $\begin{array}{l}\text { 12ZA13- } \\
55\end{array}$ & 149 & 11544 & 0.9 & 19.38 & 7.6 & 0.34 & 8.1 & 0.0471 & 2.8 & 0.35 & 296.9 & 8.1 & 293.6 & 20.7 & 267.6 & 175.0 & 296.9 & 8 & NA \\
\hline $\begin{array}{l}\text { 12ZA13- } \\
38\end{array}$ & 218 & 2819 & 0.8 & 18.81 & 10.5 & 0.35 & 11.4 & 0.0483 & 4.4 & 0.39 & 304.1 & 13.2 & 307.8 & 30.4 & 336.2 & 239.3 & 304.1 & 13 & NA \\
\hline $\begin{array}{l}\text { 12ZA13- } \\
70\end{array}$ & 242 & 14036 & 2.0 & 17.83 & 3.5 & 0.38 & 4.3 & 0.0485 & 2.6 & 0.59 & 305.5 & 7.7 & 323.5 & 12.0 & 455.3 & 77.7 & 305.5 & 8 & NA \\
\hline $\begin{array}{l}\text { 12ZA13- } \\
31\end{array}$ & 158 & 5807 & 0.4 & 18.90 & 5.9 & 0.35 & 6.3 & 0.0486 & 2.1 & 0.33 & 305.6 & 6.1 & 307.9 & 16.6 & 324.7 & 134.3 & 305.6 & 6 & NA \\
\hline $\begin{array}{l}\text { 12ZA13- } \\
43\end{array}$ & 297 & 1459 & 1.1 & 16.44 & 5.9 & 0.41 & 8.7 & 0.0487 & 6.3 & 0.73 & 306.8 & 19.0 & 348.0 & 25.5 & 632.9 & 126.9 & 306.8 & 19 & NA \\
\hline $\begin{array}{l}\text { 12ZA13- } \\
36\end{array}$ & 259 & 3087 & 0.6 & 18.58 & 8.0 & 0.37 & 8.3 & 0.0497 & 2.1 & 0.25 & 312.9 & 6.3 & 319.0 & 22.6 & 363.9 & 180.7 & 312.9 & 6 & NA \\
\hline $\begin{array}{l}\text { 12ZA13- } \\
53\end{array}$ & 108 & 31799 & 1.8 & 16.26 & 5.8 & 0.45 & 6.5 & 0.0527 & 2.9 & 0.45 & 331.0 & 9.4 & 375.0 & 20.2 & 656.7 & 123.6 & 331.0 & 9 & NA \\
\hline $\begin{array}{l}\text { 12ZA13- } \\
41\end{array}$ & 200 & 3409 & 0.6 & 18.69 & 9.1 & 0.39 & 11.2 & 0.0528 & 6.5 & 0.58 & 331.9 & 21.1 & 334.2 & 31.8 & 350.4 & 204.9 & 331.9 & 21 & NA \\
\hline $\begin{array}{l}\text { 12ZA13- } \\
47\end{array}$ & 243 & 2723 & 0.6 & 17.75 & 7.6 & 0.41 & 7.8 & 0.0530 & 1.6 & 0.20 & 332.7 & 5.2 & 349.9 & 23.1 & 465.5 & 169.6 & 332.7 & 5 & NA \\
\hline $\begin{array}{l}\text { 12ZA13- } \\
17\end{array}$ & 291 & 17928 & 4.5 & 18.11 & 1.7 & 0.43 & 3.1 & 0.0569 & 2.6 & 0.85 & 356.8 & 9.2 & 365.5 & 9.6 & 421.3 & 36.9 & 356.8 & 9 & NA \\
\hline $\begin{array}{l}\text { 12ZA13- } \\
5\end{array}$ & 87 & 1272 & 0.8 & 17.03 & 8.5 & 0.51 & 9.6 & 0.0627 & 4.4 & 0.46 & 392.0 & 16.6 & 416.9 & 32.8 & 557.3 & 186.5 & 392.0 & 17 & NA \\
\hline
\end{tabular}




\begin{tabular}{|c|c|c|c|c|c|c|c|c|c|c|c|c|c|c|c|c|c|c|c|}
\hline Analysis & $\mathrm{U}$ & $206 \mathrm{~Pb}$ & $\mathrm{U} / \mathrm{Th}$ & $206 \mathrm{~Pb}^{*}$ & \pm & $207 \mathrm{~Pb}^{*}$ & \pm & $206 \mathrm{~Pb}^{*}$ & \pm & error & $206 \mathrm{~Pb}^{*}$ & \pm & $207 \mathrm{~Pb}^{*}$ & \pm & $206 \mathrm{~Pb}^{*}$ & \pm & $\begin{array}{c}\text { Best } \\
\text { age }\end{array}$ & \pm & Conc \\
\hline & (ppm) & $204 \mathrm{~Pb}$ & & $207 \mathrm{~Pb}^{*}$ & (\%) & $235 \mathrm{U}^{*}$ & (\%) & $238 \mathrm{U}$ & $(\%)$ & corr. & $238 \mathrm{U}^{*}$ & (Ma) & $235 \mathrm{U}$ & (Ma) & $207 \mathrm{~Pb}^{*}$ & (Ma) & (Ma) & (Ma) & $(\%)$ \\
\hline $\begin{array}{l}\text { 12ZA13- } \\
15\end{array}$ & 192 & 45434 & 0.9 & 17.28 & 2.8 & 0.53 & 3.5 & 0.0660 & 2.0 & 0.57 & 412.0 & 8.0 & 429.6 & 12.2 & 525.1 & 62.5 & 412.0 & 8 & 78.5 \\
\hline $\begin{array}{l}\text { 12ZA13- } \\
60\end{array}$ & 324 & 3336 & 2.3 & 17.69 & 3.1 & 0.52 & 3.6 & 0.0671 & 2.0 & 0.54 & 418.6 & 8.0 & 427.2 & 12.7 & 473.7 & 67.7 & 418.6 & 8 & 88.4 \\
\hline $\begin{array}{l}\text { 12ZA13- } \\
11\end{array}$ & 207 & 55449 & 2.3 & 17.95 & 1.8 & 0.52 & 2.3 & 0.0676 & 1.5 & 0.64 & 421.6 & 6.0 & 424.7 & 8.0 & 441.2 & 39.3 & 421.6 & 6 & 95.6 \\
\hline $\begin{array}{l}\text { 12ZA13- } \\
6\end{array}$ & 147 & 25138 & 4.9 & 17.58 & 2.1 & 0.55 & 6.3 & 0.0700 & 5.9 & 0.94 & 435.9 & 25.1 & 444.2 & 22.7 & 487.6 & 47.0 & 435.9 & 25 & 89.4 \\
\hline $\begin{array}{l}\text { 12ZA13- } \\
40\end{array}$ & 123 & 665 & 1.8 & 15.00 & 15.1 & 0.66 & 15.1 & 0.0717 & 1.0 & 0.07 & 446.6 & 4.4 & 514.4 & 61.1 & 828.0 & 316.5 & 446.6 & 4 & 53.9 \\
\hline $\begin{array}{l}\text { 12ZA13- } \\
13\end{array}$ & 211 & 3675 & 2.9 & 16.33 & 8.0 & 0.65 & 8.9 & 0.0764 & 3.9 & 0.44 & 474.7 & 17.8 & 505.5 & 35.5 & 647.6 & 172.3 & 474.7 & 18 & 73.3 \\
\hline $\begin{array}{l}\text { 12ZA13- } \\
51\end{array}$ & 276 & 46865 & 2.3 & 17.29 & 1.6 & 0.61 & 2.3 & 0.0770 & 1.7 & 0.71 & 478.4 & 7.6 & 486.4 & 9.0 & 523.8 & 35.7 & 478.4 & 8 & 91.3 \\
\hline $\begin{array}{l}\text { 12ZA13- } \\
34\end{array}$ & 167 & 38720 & 2.2 & 15.02 & 2.0 & 0.71 & 4.1 & 0.0777 & 3.6 & 0.88 & 482.6 & 16.7 & 546.9 & 17.4 & 824.8 & 41.4 & 482.6 & 17 & 58.5 \\
\hline $\begin{array}{l}\text { 12ZA13- } \\
63\end{array}$ & 121 & 23033 & 2.0 & 17.84 & 3.2 & 0.61 & 3.7 & 0.0786 & 1.8 & 0.49 & 487.5 & 8.4 & 481.8 & 14.2 & 454.9 & 71.9 & 487.5 & 8 & 107.2 \\
\hline $\begin{array}{l}\text { 12ZA13- } \\
19\end{array}$ & 247 & 7465 & 1.6 & 17.59 & 2.0 & 0.62 & 2.2 & 0.0788 & 1.0 & 0.43 & 489.2 & 4.5 & 488.7 & 8.7 & 486.0 & 44.7 & 489.2 & 4 & 100.7 \\
\hline $\begin{array}{l}\text { 12ZA13- } \\
58\end{array}$ & 247 & 13550 & 3.2 & 17.26 & 2.4 & 0.63 & 4.2 & 0.0792 & 3.5 & 0.82 & 491.2 & 16.4 & 497.7 & 16.7 & 528.0 & 53.5 & 491.2 & 16 & 93.0 \\
\hline $\begin{array}{l}\text { 12ZA13- } \\
29\end{array}$ & 231 & 28759 & 5.2 & 17.26 & 1.9 & 0.66 & 2.3 & 0.0825 & 1.3 & 0.56 & 511.0 & 6.3 & 514.0 & 9.3 & 527.5 & 41.8 & 511.0 & 6 & 96.9 \\
\hline $\begin{array}{l}\text { 12ZA13- } \\
1\end{array}$ & 226 & 115132 & 1.6 & 17.35 & 1.7 & 0.68 & 2.0 & 0.0858 & 0.9 & 0.47 & 530.8 & 4.7 & 528.0 & 8.1 & 515.9 & 38.2 & 530.8 & 5 & 102.9 \\
\hline $\begin{array}{l}\text { 12ZA13- } \\
25\end{array}$ & 175 & 80071 & 1.5 & 16.66 & 2.1 & 0.74 & 2.7 & 0.0898 & 1.6 & 0.60 & 554.2 & 8.6 & 564.1 & 11.6 & 604.0 & 46.4 & 554.2 & 9 & 91.7 \\
\hline $\begin{array}{l}\text { 12ZA13- } \\
27\end{array}$ & 327 & 59989 & 1.8 & 17.10 & 1.8 & 0.72 & 2.2 & 0.0898 & 1.3 & 0.58 & 554.3 & 6.8 & 553.1 & 9.4 & 548.3 & 39.4 & 554.3 & 7 & 101.1 \\
\hline $\begin{array}{l}\text { 12ZA13- } \\
32\end{array}$ & 241 & 9977 & 3.8 & 16.33 & 1.3 & 0.76 & 3.9 & 0.0901 & 3.6 & 0.94 & 555.9 & 19.4 & 574.4 & 16.9 & 648.2 & 27.3 & 555.9 & 19 & 85.8 \\
\hline $\begin{array}{l}\text { 12ZA13- } \\
3\end{array}$ & 574 & 46396 & 13.7 & 16.88 & 0.8 & 0.75 & 1.4 & 0.0923 & 1.1 & 0.80 & 569.0 & 6.2 & 570.3 & 6.2 & 575.8 & 18.3 & 569.0 & 6 & 98.8 \\
\hline $\begin{array}{l}\text { 12ZA13- } \\
24\end{array}$ & 350 & 8111 & 0.5 & 15.45 & 9.6 & 0.83 & 11.5 & 0.0930 & 6.4 & 0.55 & 573.0 & 34.8 & 613.3 & 53.0 & 765.0 & 202.5 & 573.0 & 35 & 74.9 \\
\hline $\begin{array}{l}\text { 12ZA13- } \\
56\end{array}$ & 184 & 6141 & 1.1 & 17.21 & 3.4 & 0.76 & 3.9 & 0.0945 & 1.8 & 0.48 & 581.9 & 10.3 & 572.1 & 16.9 & 533.4 & 74.0 & 581.9 & 10 & 109.1 \\
\hline $\begin{array}{l}\text { 12ZA13- } \\
46\end{array}$ & 111 & 32904 & 2.0 & 14.35 & 2.9 & 1.18 & 3.9 & 0.1233 & 2.6 & 0.67 & 749.5 & 18.6 & 793.6 & 21.7 & 919.3 & 60.3 & 749.5 & 19 & 81.5 \\
\hline $\begin{array}{l}\text { 12ZA13- } \\
2\end{array}$ & 199 & 28216 & 1.1 & 13.74 & 0.7 & 1.47 & 2.1 & 0.1461 & 2.0 & 0.94 & 879.1 & 16.1 & 916.5 & 12.6 & 1007.6 & 14.5 & 1007.6 & 15 & 87.2 \\
\hline $\begin{array}{l}\text { 12ZA13- } \\
14\end{array}$ & 95 & 68488 & 2.4 & 13.63 & 2.0 & 1.77 & 2.3 & 0.1753 & 1.1 & 0.48 & 1041.4 & 10.6 & 1036.0 & 14.9 & 1024.7 & 40.9 & 1024.7 & 41 & 101.6 \\
\hline $\begin{array}{l}\text { 12ZA13- } \\
44\end{array}$ & 320 & 44900 & 2.6 & 13.56 & 0.8 & 1.74 & 1.7 & 0.1715 & 1.4 & 0.86 & 1020.5 & 13.6 & 1024.9 & 10.8 & 1034.3 & 17.0 & 1034.3 & 17 & 98.7 \\
\hline $\begin{array}{l}\text { 12ZA13- } \\
37\end{array}$ & 156 & 77717 & 0.7 & 12.16 & 0.6 & 2.53 & 1.6 & 0.2236 & 1.5 & 0.92 & 1301.0 & 17.3 & 1282.1 & 11.7 & 1250.5 & 12.5 & 1250.5 & 13 & 104.0 \\
\hline $\begin{array}{l}\text { 12ZA26- } \\
38\end{array}$ & 298 & 665 & 2.5 & 16.03 & 13.3 & 0.34 & 15.5 & 0.0399 & 7.9 & 0.51 & 252.3 & 19.6 & 299.6 & 40.1 & 687.1 & 284.6 & 252.3 & 20 & NA \\
\hline $\begin{array}{l}\text { 12ZA26- } \\
12\end{array}$ & 437 & 51549 & 13.2 & 18.71 & 2.6 & 0.30 & 5.1 & 0.0412 & 4.3 & 0.85 & 260.6 & 11.0 & 269.4 & 12.0 & 347.3 & 59.9 & 260.6 & 11 & NA \\
\hline $\begin{array}{l}\text { 12ZA26- } \\
7\end{array}$ & 90 & 26554 & 0.9 & 15.95 & 13.5 & 0.36 & 13.9 & 0.0420 & 3.4 & 0.24 & 265.2 & 8.8 & 314.5 & 37.7 & 698.5 & 289.4 & 265.2 & 9 & NA \\
\hline $\begin{array}{l}\text { 12ZA26- } \\
9\end{array}$ & 522 & 3041 & 1.5 & 18.41 & 3.9 & 0.32 & 5.1 & 0.0423 & 3.3 & 0.65 & 266.9 & 8.7 & 279.3 & 12.5 & 384.4 & 86.7 & 266.9 & 9 & NA \\
\hline $\begin{array}{l}\text { 12ZA26- } \\
61\end{array}$ & 383 & 9090 & 1.4 & 18.87 & 2.7 & 0.31 & 4.4 & 0.0426 & 3.4 & 0.78 & 269.2 & 9.0 & 275.3 & 10.6 & 328.3 & 62.2 & 269.2 & 9 & NA \\
\hline $\begin{array}{l}\text { 12ZA26- } \\
3\end{array}$ & 379 & 7183 & 0.9 & 18.79 & 1.7 & 0.31 & 2.8 & 0.0427 & 2.2 & 0.79 & 269.3 & 5.9 & 276.5 & 6.8 & 338.1 & 39.1 & 269.3 & 6 & NA \\
\hline $\begin{array}{l}\text { 12ZA26- } \\
5\end{array}$ & 435 & 1594 & 1.2 & 16.97 & 12.7 & 0.35 & 13.2 & 0.0427 & 3.3 & 0.25 & 269.7 & 8.8 & 302.5 & 34.5 & 563.9 & 278.7 & 269.7 & 9 & NA \\
\hline $\begin{array}{l}\text { 12ZA26- } \\
66\end{array}$ & 369 & 5868 & 1.0 & 18.80 & 3.8 & 0.31 & 3.9 & 0.0428 & 0.8 & 0.20 & 270.4 & 2.1 & 277.4 & 9.5 & 337.2 & 86.7 & 270.4 & 2 & NA \\
\hline $\begin{array}{l}\text { 12ZA26- } \\
19\end{array}$ & 330 & 2779 & 1.2 & 18.13 & 5.9 & 0.33 & 6.1 & 0.0429 & 1.5 & 0.25 & 271.0 & 4.1 & 286.9 & 15.2 & 418.6 & 131.2 & 271.0 & 4 & NA \\
\hline $\begin{array}{l}\text { 12ZA26- } \\
28\end{array}$ & 268 & 1158 & 0.9 & 17.44 & 5.1 & 0.34 & 5.3 & 0.0432 & 1.5 & 0.29 & 272.9 & 4.1 & 298.6 & 13.7 & 504.5 & 111.3 & 272.9 & 4 & NA \\
\hline $\begin{array}{l}\text { 12ZA26- } \\
42\end{array}$ & 524 & 13065 & 1.2 & 18.83 & 2.5 & 0.32 & 4.3 & 0.0434 & 3.5 & 0.81 & 273.8 & 9.3 & 280.1 & 10.6 & 333.3 & 57.6 & 273.8 & 9 & NA \\
\hline $\begin{array}{l}\text { 12ZA26- } \\
15\end{array}$ & 297 & 22979 & 1.5 & 18.40 & 5.4 & 0.33 & 6.0 & 0.0434 & 2.5 & 0.42 & 273.9 & 6.7 & 285.9 & 14.9 & 384.9 & 122.4 & 273.9 & 7 & NA \\
\hline $\begin{array}{l}\text { 12ZA26- } \\
18\end{array}$ & 586 & 109371 & 1.7 & 19.23 & 2.0 & 0.31 & 2.4 & 0.0435 & 1.3 & 0.53 & 274.3 & 3.4 & 275.4 & 5.7 & 285.1 & 45.9 & 274.3 & 3 & NA \\
\hline $\begin{array}{l}\text { 12ZA26- } \\
44\end{array}$ & 316 & 17938 & 1.0 & 19.21 & 2.7 & 0.31 & 3.5 & 0.0435 & 2.3 & 0.65 & 274.8 & 6.2 & 276.1 & 8.5 & 287.5 & 61.5 & 274.8 & 6 & NA \\
\hline $\begin{array}{l}\text { 12ZA26- } \\
65\end{array}$ & 155 & 15146 & 1.0 & 19.91 & 6.4 & 0.30 & 6.8 & 0.0438 & 2.1 & 0.31 & 276.3 & 5.7 & 269.0 & 16.0 & 205.3 & 149.0 & 276.3 & 6 & NA \\
\hline
\end{tabular}




\begin{tabular}{|c|c|c|c|c|c|c|c|c|c|c|c|c|c|c|c|c|c|c|c|}
\hline Analysis & $\mathrm{U}$ & $206 \mathrm{~Pb}$ & $\mathrm{U} / \mathrm{Th}$ & $206 \mathrm{~Pb}^{*}$ & \pm & $207 \mathrm{~Pb}^{*}$ & \pm & $206 \mathrm{~Pb}^{*}$ & \pm & error & $206 \mathrm{~Pb}^{*}$ & \pm & $207 \mathrm{~Pb}^{*}$ & \pm & $206 \mathrm{~Pb}^{*}$ & \pm & $\begin{array}{c}\text { Best } \\
\text { age }\end{array}$ & \pm & Conc \\
\hline & (ppm) & $204 \mathrm{~Pb}$ & & $207 \mathrm{~Pb}^{*}$ & $(\%)$ & $235 \mathrm{U}^{*}$ & $(\%)$ & $238 \mathrm{U}$ & $(\%)$ & corr. & $238 \mathrm{U}^{*}$ & (Ma) & $235 \mathrm{U}$ & (Ma) & $207 \mathrm{~Pb}^{*}$ & (Ma) & (Ma) & (Ma) & $(\%)$ \\
\hline $\begin{array}{l}\text { 12ZA26- } \\
17\end{array}$ & 271 & 4151 & 1.0 & 18.13 & 6.9 & 0.33 & 7.3 & 0.0438 & 2.6 & 0.35 & 276.5 & 7.0 & 292.1 & 18.6 & 418.8 & 153.4 & 276.5 & 7 & NA \\
\hline $\begin{array}{l}\text { 12ZA26- } \\
21\end{array}$ & 377 & 2075 & 1.5 & 16.93 & 15.5 & 0.36 & 15.7 & 0.0440 & 2.4 & 0.15 & 277.3 & 6.4 & 310.7 & 42.1 & 569.7 & 339.8 & 277.3 & 6 & NA \\
\hline $\begin{array}{l}\text { 12ZA26- } \\
14\end{array}$ & 336 & 3853 & 1.2 & 17.58 & 5.5 & 0.35 & 6.5 & 0.0440 & 3.4 & 0.52 & 277.6 & 9.1 & 301.0 & 16.8 & 486.5 & 122.0 & 277.6 & 9 & NA \\
\hline $\begin{array}{l}\text { 12ZA26- } \\
47\end{array}$ & 222 & 3254 & 0.7 & 17.35 & 9.8 & 0.35 & 10.2 & 0.0440 & 2.8 & 0.28 & 277.7 & 7.7 & 304.6 & 26.8 & 516.2 & 215.4 & 277.7 & 8 & NA \\
\hline $\begin{array}{l}\text { 12ZA26- } \\
13\end{array}$ & 429 & 20134 & 1.4 & 18.36 & 3.8 & 0.33 & 3.9 & 0.0441 & 0.9 & 0.22 & 278.0 & 2.4 & 290.2 & 9.9 & 390.1 & 86.2 & 278.0 & 2 & NA \\
\hline $\begin{array}{l}\text { 12ZA26- } \\
30\end{array}$ & 234 & 26868 & 0.8 & 19.24 & 3.4 & 0.32 & 5.4 & 0.0444 & 4.2 & 0.78 & 279.8 & 11.6 & 280.2 & 13.3 & 284.0 & 76.8 & 279.8 & 12 & NA \\
\hline $\begin{array}{l}\text { 12ZA26- } \\
8\end{array}$ & 40 & 6782 & 2.1 & 25.15 & 29.3 & 0.24 & 29.4 & 0.0445 & 2.3 & 0.08 & 280.4 & 6.4 & 221.4 & 58.6 & -366.9 & 773.5 & 280.4 & 6 & NA \\
\hline $\begin{array}{l}\text { 12ZA26- } \\
11\end{array}$ & 146 & 6344 & 1.4 & 17.97 & 5.8 & 0.34 & 5.9 & 0.0446 & 1.3 & 0.22 & 281.0 & 3.6 & 298.6 & 15.4 & 438.4 & 128.8 & 281.0 & 4 & NA \\
\hline $\begin{array}{l}\text { 12ZA26- } \\
32\end{array}$ & 314 & 40669 & 1.7 & 19.33 & 3.1 & 0.32 & 3.3 & 0.0446 & 0.9 & 0.26 & 281.6 & 2.4 & 280.7 & 8.0 & 273.1 & 72.0 & 281.6 & 2 & NA \\
\hline $\begin{array}{l}\text { 12ZA26- } \\
34\end{array}$ & 380 & 2358 & 1.2 & 18.47 & 4.1 & 0.33 & 4.7 & 0.0447 & 2.3 & 0.48 & 282.1 & 6.2 & 292.5 & 12.0 & 376.5 & 92.9 & 282.1 & 6 & NA \\
\hline $\begin{array}{l}\text { 12ZA26- } \\
63\end{array}$ & 280 & 30486 & 1.5 & 19.24 & 3.5 & 0.32 & 3.6 & 0.0449 & 0.8 & 0.22 & 283.0 & 2.2 & 283.1 & 8.9 & 283.9 & 80.6 & 283.0 & 2 & NA \\
\hline $\begin{array}{l}\text { 12ZA26- } \\
68\end{array}$ & 221 & 7037 & 1.4 & 18.51 & 7.3 & 0.34 & 7.6 & 0.0455 & 2.1 & 0.28 & 286.8 & 6.0 & 296.3 & 19.5 & 371.7 & 164.3 & 286.8 & 6 & NA \\
\hline $\begin{array}{l}\text { 12ZA26- } \\
55\end{array}$ & 371 & 25159 & 1.4 & 18.89 & 3.6 & 0.34 & 5.0 & 0.0464 & 3.6 & 0.71 & 292.7 & 10.3 & 296.4 & 13.0 & 326.1 & 80.7 & 292.7 & 10 & NA \\
\hline $\begin{array}{l}\text { 12ZA26- } \\
1\end{array}$ & 275 & 10914 & 0.9 & 18.76 & 3.2 & 0.34 & 3.4 & 0.0467 & 0.9 & 0.27 & 294.2 & 2.6 & 299.6 & 8.7 & 342.4 & 73.2 & 294.2 & 3 & NA \\
\hline $\begin{array}{l}\text { 12ZA26- } \\
27 \\
\end{array}$ & 142 & 40282 & 1.0 & 19.10 & 7.7 & 0.34 & 8.7 & 0.0469 & 4.2 & 0.48 & 295.2 & 12.1 & 295.9 & 22.5 & 301.2 & 175.3 & 295.2 & 12 & NA \\
\hline $\begin{array}{l}\text { 12ZA26- } \\
46\end{array}$ & 841 & 4679 & 2.4 & 18.15 & 6.7 & 0.36 & 6.7 & 0.0474 & 1.0 & 0.15 & 298.4 & 2.9 & 312.2 & 18.1 & 416.2 & 148.9 & 298.4 & 3 & NA \\
\hline $\begin{array}{l}\text { 12ZA26- } \\
40\end{array}$ & 332 & 10260 & 1.6 & 18.85 & 6.1 & 0.35 & 8.7 & 0.0480 & 6.2 & 0.71 & 302.4 & 18.4 & 305.7 & 23.0 & 331.1 & 138.8 & 302.4 & 18 & NA \\
\hline $\begin{array}{l}\text { 12ZA26- } \\
39\end{array}$ & 153 & 34495 & 1.4 & 19.64 & 4.7 & 0.34 & 5.0 & 0.0482 & 1.5 & 0.30 & 303.5 & 4.4 & 296.0 & 12.7 & 237.1 & 109.3 & 303.5 & 4 & NA \\
\hline $\begin{array}{l}\text { 12ZA26- } \\
25\end{array}$ & 224 & 2420 & 0.6 & 17.86 & 12.2 & 0.37 & 12.5 & 0.0485 & 2.5 & 0.20 & 305.3 & 7.5 & 322.9 & 34.6 & 452.0 & 272.6 & 305.3 & 7 & NA \\
\hline $\begin{array}{l}\text { 12ZA26- } \\
53\end{array}$ & 232 & 25383 & 1.8 & 18.94 & 5.0 & 0.36 & 5.3 & 0.0491 & 1.8 & 0.33 & 308.7 & 5.3 & 310.1 & 14.1 & 320.0 & 112.9 & 308.7 & 5 & NA \\
\hline $\begin{array}{l}\text { 12ZA26- } \\
4\end{array}$ & 206 & 726 & 0.8 & 17.00 & 14.3 & 0.40 & 14.4 & 0.0492 & 1.8 & 0.13 & 309.6 & 5.5 & 341.0 & 41.8 & 560.9 & 313.5 & 309.6 & 6 & NA \\
\hline $\begin{array}{l}\text { 12ZA26- } \\
62\end{array}$ & 123 & 3782 & 0.9 & 17.27 & 12.3 & 0.40 & 12.4 & 0.0503 & 1.3 & 0.10 & 316.1 & 3.9 & 342.5 & 36.0 & 525.7 & 270.6 & 316.1 & 4 & NA \\
\hline $\begin{array}{l}\text { 12ZA26- } \\
29\end{array}$ & 97 & 27229 & 1.8 & 17.69 & 6.6 & 0.47 & 6.7 & 0.0607 & 1.2 & 0.18 & 380.0 & 4.5 & 393.5 & 21.8 & 473.5 & 145.3 & 380.0 & 5 & NA \\
\hline $\begin{array}{l}12 Z A 26- \\
59\end{array}$ & 298 & 1198 & 1.6 & 14.06 & 4.9 & 0.65 & 6.8 & 0.0660 & 4.8 & 0.69 & 412.1 & 19.0 & 506.8 & 27.3 & 960.5 & 100.6 & 412.1 & 19 & 42.9 \\
\hline $\begin{array}{l}\text { 12ZA26- } \\
49\end{array}$ & 376 & 74531 & 1.6 & 17.28 & 1.8 & 0.56 & 5.5 & 0.0703 & 5.2 & 0.94 & 438.1 & 22.2 & 452.3 & 20.2 & 524.8 & 39.9 & 438.1 & 22 & 83.5 \\
\hline $\begin{array}{l}\text { 12ZA26- } \\
41\end{array}$ & 554 & 11652 & 6.6 & 16.81 & 9.4 & 0.60 & 9.4 & 0.0731 & 1.2 & 0.13 & 454.8 & 5.4 & 477.0 & 35.9 & 585.3 & 203.5 & 454.8 & 5 & 77.7 \\
\hline $\begin{array}{l}\text { 12ZA26- } \\
37\end{array}$ & 357 & 12285 & 1.0 & 17.03 & 4.7 & 0.62 & 4.8 & 0.0763 & 0.9 & 0.18 & 473.7 & 3.9 & 488.3 & 18.6 & 557.1 & 103.0 & 473.7 & 4 & 85.0 \\
\hline $\begin{array}{l}\text { 12ZA26- } \\
45\end{array}$ & 173 & 15597 & 2.2 & 17.39 & 2.8 & 0.62 & 2.9 & 0.0786 & 0.8 & 0.27 & 487.6 & 3.7 & 491.7 & 11.3 & 510.7 & 61.2 & 487.6 & 4 & 95.5 \\
\hline $\begin{array}{l}\text { 12ZA26- } \\
20\end{array}$ & 153 & 6792 & 1.1 & 16.05 & 8.4 & 0.68 & 8.6 & 0.0794 & 1.6 & 0.19 & 492.5 & 7.6 & 528.1 & 35.3 & 685.0 & 180.0 & 492.5 & 8 & 71.9 \\
\hline $\begin{array}{l}\text { 12ZA26- } \\
26\end{array}$ & 104 & 13089 & 1.1 & 17.53 & 5.6 & 0.65 & 5.7 & 0.0820 & 1.3 & 0.24 & 508.3 & 6.6 & 505.6 & 22.8 & 493.2 & 122.9 & 508.3 & 7 & 103.1 \\
\hline $\begin{array}{l}12 Z \text { Z26- } \\
33\end{array}$ & 228 & 33389 & 1.3 & 17.31 & 2.0 & 0.66 & 2.3 & 0.0826 & 1.1 & 0.47 & 511.5 & 5.3 & 513.3 & 9.2 & 521.2 & 44.5 & 511.5 & 5 & 98.1 \\
\hline $\begin{array}{l}\text { 12ZA26- } \\
69 \\
\end{array}$ & 372 & 2857 & 0.9 & 16.20 & 6.3 & 0.70 & 6.5 & 0.0828 & 1.5 & 0.24 & 512.5 & 7.6 & 541.3 & 27.4 & 664.2 & 135.9 & 512.5 & 8 & 77.2 \\
\hline $\begin{array}{l}\text { 12ZA26- } \\
57\end{array}$ & 187 & 47909 & 1.1 & 17.24 & 2.7 & 0.67 & 3.6 & 0.0840 & 2.3 & 0.65 & 520.0 & 11.5 & 521.9 & 14.6 & 530.5 & 59.7 & 520.0 & 12 & 98.0 \\
\hline $\begin{array}{l}\text { 12ZA26- } \\
52\end{array}$ & 138 & 2724 & 2.6 & 15.63 & 11.6 & 0.76 & 11.7 & 0.0863 & 1.8 & 0.15 & 533.5 & 9.0 & 574.7 & 51.4 & 740.9 & 245.8 & 533.5 & 9 & 72.0 \\
\hline $\begin{array}{l}\text { 12ZA26- } \\
50\end{array}$ & 197 & 2764 & 3.5 & 16.62 & 4.6 & 0.72 & 5.7 & 0.0872 & 3.3 & 0.59 & 539.0 & 17.2 & 552.6 & 24.1 & 609.0 & 98.8 & 539.0 & 17 & 88.5 \\
\hline $\begin{array}{l}\text { 12ZA26- } \\
10\end{array}$ & 257 & 212156 & 51.2 & 16.96 & 0.9 & 0.76 & 1.1 & 0.0931 & 0.7 & 0.63 & 574.1 & 3.9 & 572.4 & 4.9 & 565.5 & 19.1 & 574.1 & 4 & 101.5 \\
\hline $\begin{array}{l}12 \text { ZA26- } \\
58\end{array}$ & 269 & 144496 & 1.5 & 16.74 & 1.3 & 0.80 & 1.7 & 0.0966 & 1.2 & 0.68 & 594.2 & 6.7 & 594.1 & 7.8 & 593.6 & 27.7 & 594.2 & 7 & 100.1 \\
\hline $\begin{array}{l}\text { 12ZA26- } \\
31\end{array}$ & 99 & 117858 & 1.2 & 12.23 & 1.1 & 2.48 & 1.7 & 0.2197 & 1.3 & 0.77 & 1280.0 & 14.9 & 1265.1 & 12.1 & 1239.8 & 21.1 & 1239.8 & 21 & 103.2 \\
\hline $\begin{array}{l}\text { 09BLC1- } \\
23 \\
\end{array}$ & 69 & 10354 & 1.4 & 19.86 & 19.8 & 0.29 & 20.3 & 0.0420 & 4.5 & 0.22 & 265.0 & 11.8 & 259.6 & 46.6 & 211.1 & 462.7 & 265.0 & 12 & NA \\
\hline
\end{tabular}




\begin{tabular}{|c|c|c|c|c|c|c|c|c|c|c|c|c|c|c|c|c|c|c|c|}
\hline Analysis & $\mathrm{U}$ & $206 \mathrm{~Pb}$ & $\mathrm{U} / \mathrm{Th}$ & $206 \mathrm{~Pb}^{*}$ & \pm & $207 \mathrm{~Pb}^{*}$ & \pm & $206 \mathrm{~Pb}^{*}$ & \pm & error & $206 \mathrm{~Pb}^{*}$ & \pm & $207 \mathrm{~Pb}^{*}$ & \pm & $206 \mathrm{~Pb}^{*}$ & \pm & $\begin{array}{c}\text { Best } \\
\text { age }\end{array}$ & \pm & Conc \\
\hline & (ppm) & $204 \mathrm{~Pb}$ & & $207 \mathrm{~Pb}^{*}$ & $(\%)$ & $235 \mathrm{U}^{*}$ & $(\%)$ & $238 \mathrm{U}$ & $(\%)$ & corr. & $238 \mathrm{U}^{*}$ & (Ma) & $235 \mathrm{U}$ & (Ma) & $207 \mathrm{~Pb}^{*}$ & (Ma) & (Ma) & (Ma) & $(\%)$ \\
\hline $\begin{array}{l}\text { 09BLC1- } \\
15\end{array}$ & 144 & 5236 & 1.4 & 18.60 & 8.2 & 0.32 & 8.6 & 0.0431 & 2.6 & 0.30 & 271.9 & 6.9 & 281.3 & 21.2 & 360.8 & 185.6 & 271.9 & 7 & NA \\
\hline $\begin{array}{l}\text { 09BLC1- } \\
2\end{array}$ & 532 & 3890 & 3.0 & 18.69 & 6.7 & 0.32 & 7.8 & 0.0431 & 3.9 & 0.50 & 272.2 & 10.3 & 280.5 & 19.0 & 350.5 & 152.2 & 272.2 & 10 & NA \\
\hline $\begin{array}{l}\text { 09BLC1- } \\
100\end{array}$ & 254 & 1844 & 0.8 & 19.26 & 9.3 & 0.31 & 9.5 & 0.0432 & 2.0 & 0.21 & 272.4 & 5.4 & 273.4 & 22.7 & 282.3 & 212.2 & 272.4 & 5 & NA \\
\hline $\begin{array}{l}\text { 09BLC1- } \\
7\end{array}$ & 171 & 15801 & 0.9 & 19.17 & 7.5 & 0.31 & 7.9 & 0.0433 & 2.3 & 0.30 & 273.1 & 6.3 & 275.1 & 19.0 & 292.2 & 171.7 & 273.1 & 6 & NA \\
\hline $\begin{array}{l}\text { 09BLC1- } \\
18\end{array}$ & 108 & 23625 & 1.4 & 20.07 & 8.8 & 0.30 & 9.0 & 0.0434 & 1.7 & 0.19 & 273.8 & 4.6 & 264.8 & 20.9 & 186.5 & 204.8 & 273.8 & 5 & NA \\
\hline $\begin{array}{l}\text { 09BLC1- } \\
33\end{array}$ & 89 & 10994 & 0.9 & 20.64 & 22.0 & 0.29 & 22.1 & 0.0437 & 2.5 & 0.11 & 275.9 & 6.7 & 260.2 & 50.8 & 121.1 & 523.2 & 275.9 & 7 & NA \\
\hline $\begin{array}{l}\text { 09BLC1- } \\
28\end{array}$ & 98 & 8750 & 0.7 & 20.99 & 19.1 & 0.29 & 19.2 & 0.0439 & 1.6 & 0.09 & 277.0 & 4.4 & 257.3 & 43.7 & 81.5 & 457.7 & 277.0 & 4 & NA \\
\hline $\begin{array}{l}\text { 09BLC1- } \\
67\end{array}$ & 303 & 36082 & 1.5 & 19.31 & 3.4 & 0.31 & 3.5 & 0.0440 & 1.0 & 0.29 & 277.3 & 2.8 & 277.2 & 8.6 & 276.2 & 77.9 & 277.3 & 3 & NA \\
\hline $\begin{array}{l}\text { 09BLC1- } \\
99\end{array}$ & 330 & 37308 & 1.1 & 19.72 & 3.8 & 0.31 & 5.1 & 0.0440 & 3.4 & 0.67 & 277.6 & 9.2 & 272.4 & 12.2 & 227.6 & 87.7 & 277.6 & 9 & NA \\
\hline $\begin{array}{l}\text { 09BLC1- } \\
84\end{array}$ & 143 & 17511 & 1.5 & 18.25 & 5.2 & 0.33 & 6.6 & 0.0441 & 4.1 & 0.62 & 278.5 & 11.3 & 292.3 & 16.9 & 404.4 & 116.3 & 278.5 & 11 & NA \\
\hline $\begin{array}{l}\text { 09BLC1- } \\
48\end{array}$ & 401 & 52000 & 0.9 & 19.17 & 1.7 & 0.32 & 2.0 & 0.0443 & 1.1 & 0.52 & 279.2 & 2.9 & 280.6 & 5.0 & 292.0 & 39.9 & 279.2 & 3 & NA \\
\hline $\begin{array}{l}\text { 09BLC1- } \\
76\end{array}$ & 235 & 15800 & 0.8 & 18.38 & 5.1 & 0.34 & 5.2 & 0.0447 & 1.2 & 0.23 & 281.9 & 3.2 & 293.5 & 13.2 & 387.3 & 113.8 & 281.9 & 3 & NA \\
\hline $\begin{array}{l}\text { 09BLC1- } \\
93\end{array}$ & 135 & 10803 & 1.0 & 19.19 & 6.4 & 0.33 & 6.6 & 0.0453 & 1.8 & 0.28 & 285.6 & 5.1 & 286.0 & 16.6 & 289.7 & 146.1 & 285.6 & 5 & NA \\
\hline $\begin{array}{l}\text { 09BLC1- } \\
83\end{array}$ & 115 & 10281 & 1.7 & 18.52 & 6.3 & 0.34 & 7.6 & 0.0456 & 4.3 & 0.56 & 287.3 & 12.1 & 296.7 & 19.6 & 371.3 & 142.3 & 287.3 & 12 & NA \\
\hline $\begin{array}{l}\text { 09BLC1- } \\
41\end{array}$ & 102 & 19594 & 1.2 & 19.32 & 11.5 & 0.33 & 11.7 & 0.0461 & 2.3 & 0.19 & 290.3 & 6.4 & 288.5 & 29.5 & 274.5 & 264.3 & 290.3 & 6 & NA \\
\hline $\begin{array}{l}\text { 09BLC1- } \\
50\end{array}$ & 348 & 34704 & 1.1 & 19.04 & 3.7 & 0.34 & 3.7 & 0.0466 & 0.7 & 0.19 & 293.5 & 2.0 & 295.2 & 9.6 & 308.6 & 83.6 & 293.5 & 2 & NA \\
\hline $\begin{array}{l}\text { 09BLC1- } \\
12\end{array}$ & 196 & 20906 & 1.4 & 19.21 & 7.7 & 0.34 & 7.8 & 0.0471 & 1.3 & 0.17 & 296.4 & 3.9 & 295.5 & 20.0 & 288.3 & 175.9 & 296.4 & 4 & NA \\
\hline $\begin{array}{l}\text { 09BLC1- } \\
6\end{array}$ & 233 & 52952 & 1.4 & 19.50 & 4.5 & 0.34 & 4.7 & 0.0484 & 1.2 & 0.27 & 304.5 & 3.7 & 298.6 & 12.0 & 253.0 & 103.1 & 304.5 & 4 & NA \\
\hline $\begin{array}{l}\text { 09BLC1- } \\
40\end{array}$ & 139 & 13501 & 1.4 & 19.86 & 9.9 & 0.34 & 10.1 & 0.0487 & 2.1 & 0.20 & 306.5 & 6.2 & 295.6 & 25.9 & 210.7 & 229.6 & 306.5 & 6 & NA \\
\hline $\begin{array}{l}\text { 09BLC1- } \\
96\end{array}$ & 326 & 25104 & 11.6 & 18.39 & 2.3 & 0.43 & 3.4 & 0.0573 & 2.5 & 0.75 & 359.0 & 8.8 & 362.6 & 10.4 & 386.1 & 50.9 & 359.0 & 9 & NA \\
\hline $\begin{array}{l}\text { 09BLC1- } \\
53\end{array}$ & 181 & 3219 & 1.8 & 17.75 & 9.3 & 0.46 & 9.4 & 0.0589 & 1.3 & 0.14 & 368.7 & 4.8 & 382.3 & 30.0 & 465.4 & 206.7 & 368.7 & 5 & NA \\
\hline $\begin{array}{l}\text { 09BLC1- } \\
17\end{array}$ & 338 & 8100 & 0.9 & 17.61 & 3.4 & 0.50 & 4.1 & 0.0641 & 2.3 & 0.56 & 400.5 & 9.0 & 412.9 & 14.0 & 482.7 & 75.4 & 400.5 & 9 & 83.0 \\
\hline $\begin{array}{l}\text { 09BLC1- } \\
69\end{array}$ & 101 & 25216 & 1.4 & 18.91 & 9.3 & 0.47 & 9.5 & 0.0641 & 1.7 & 0.18 & 400.5 & 6.8 & 389.3 & 30.6 & 323.4 & 211.5 & 400.5 & 7 & 123.9 \\
\hline $\begin{array}{l}\text { 09BLC1- } \\
49\end{array}$ & 285 & 3773 & 1.8 & 18.12 & 4.0 & 0.50 & 6.5 & 0.0653 & 5.2 & 0.79 & 407.6 & 20.4 & 409.3 & 21.9 & 419.3 & 89.0 & 407.6 & 20 & 97.2 \\
\hline $\begin{array}{l}\text { 09BLC1- } \\
85\end{array}$ & 298 & 73097 & 2.0 & 18.11 & 2.0 & 0.50 & 2.1 & 0.0662 & 0.8 & 0.36 & 413.1 & 3.0 & 414.4 & 7.2 & 421.5 & 44.0 & 413.1 & 3 & 98.0 \\
\hline $\begin{array}{l}\text { 09BLC1- } \\
55\end{array}$ & 275 & 42670 & 2.3 & 18.27 & 2.6 & 0.51 & 2.9 & 0.0671 & 1.4 & 0.46 & 418.9 & 5.5 & 416.2 & 10.0 & 401.4 & 58.3 & 418.9 & 5 & 104.4 \\
\hline $\begin{array}{l}\text { 09BLC1- } \\
26\end{array}$ & 82 & 17165 & 0.9 & 17.93 & 11.4 & 0.52 & 13.7 & 0.0672 & 7.6 & 0.55 & 419.2 & 30.7 & 422.9 & 47.4 & 443.1 & 254.6 & 419.2 & 31 & 94.6 \\
\hline $\begin{array}{l}\text { 09BLC1- } \\
44\end{array}$ & 355 & 56647 & 7.4 & 17.96 & 2.1 & 0.56 & 2.7 & 0.0728 & 1.7 & 0.63 & 452.9 & 7.4 & 450.7 & 9.8 & 439.2 & 46.9 & 452.9 & 7 & 103.1 \\
\hline $\begin{array}{l}\text { 09BLC1- } \\
5\end{array}$ & 486 & 4672 & 2.6 & 17.30 & 3.8 & 0.59 & 4.5 & 0.0742 & 2.5 & 0.55 & 461.6 & 11.1 & 471.9 & 17.0 & 522.1 & 82.6 & 461.6 & 11 & 88.4 \\
\hline $\begin{array}{l}\text { 09BLC1- } \\
16\end{array}$ & 122 & 17852 & 2.1 & 17.57 & 5.6 & 0.59 & 5.7 & 0.0757 & 1.3 & 0.22 & 470.4 & 5.7 & 473.6 & 21.6 & 488.7 & 123.0 & 470.4 & 6 & 96.3 \\
\hline $\begin{array}{l}\text { 09BLC1- } \\
10\end{array}$ & 150 & 11856 & 1.1 & 17.11 & 4.2 & 0.61 & 4.4 & 0.0759 & 1.2 & 0.26 & 471.5 & 5.3 & 484.5 & 17.0 & 546.7 & 92.9 & 471.5 & 5 & 86.2 \\
\hline $\begin{array}{l}\text { 09BLC1- } \\
65\end{array}$ & 32 & 4848 & 1.1 & 20.05 & 12.1 & 0.53 & 12.6 & 0.0771 & 3.4 & 0.27 & 478.6 & 15.8 & 431.9 & 44.4 & 189.6 & 283.6 & 478.6 & 16 & 252.5 \\
\hline $\begin{array}{l}\text { 09BLC1- } \\
73\end{array}$ & 88 & 12595 & 1.5 & 18.87 & 8.8 & 0.57 & 8.9 & 0.0776 & 1.3 & 0.15 & 481.9 & 6.2 & 456.2 & 32.8 & 329.0 & 200.4 & 481.9 & 6 & 146.5 \\
\hline $\begin{array}{l}\text { 09BLC1- } \\
92\end{array}$ & 278 & 58156 & 1.9 & 17.75 & 2.8 & 0.60 & 2.9 & 0.0777 & 0.9 & 0.30 & 482.2 & 4.1 & 479.3 & 11.2 & 465.6 & 61.7 & 482.2 & 4 & 103.6 \\
\hline $\begin{array}{l}\text { 09BLC1- } \\
91\end{array}$ & 162 & 43171 & 3.5 & 17.61 & 2.5 & 0.61 & 2.7 & 0.0779 & 1.0 & 0.38 & 483.7 & 4.7 & 483.6 & 10.2 & 483.6 & 54.2 & 483.7 & 5 & 100.0 \\
\hline $\begin{array}{l}\text { 09BLC1- } \\
98\end{array}$ & 151 & 34238 & 1.9 & 17.67 & 3.3 & 0.62 & 3.8 & 0.0798 & 1.9 & 0.51 & 495.0 & 9.2 & 491.5 & 14.9 & 475.7 & 72.7 & 495.0 & 9 & 104.0 \\
\hline $\begin{array}{l}\text { 09BLC1- } \\
78\end{array}$ & 250 & 41987 & 1.2 & 17.70 & 3.7 & 0.62 & 4.5 & 0.0799 & 2.7 & 0.59 & 495.2 & 12.7 & 491.1 & 17.7 & 471.8 & 81.6 & 495.2 & 13 & 105.0 \\
\hline $\begin{array}{l}\text { 09BLC1- } \\
66\end{array}$ & 166 & 36029 & 2.6 & 17.47 & 3.3 & 0.64 & 3.5 & 0.0805 & 1.2 & 0.34 & 499.1 & 5.7 & 499.5 & 13.7 & 501.1 & 72.0 & 499.1 & 6 & 99.6 \\
\hline $\begin{array}{l}\text { 09BLC1- } \\
70\end{array}$ & 163 & 29964 & 1.8 & 17.24 & 4.0 & 0.67 & 4.3 & 0.0842 & 1.6 & 0.37 & 521.4 & 8.1 & 523.0 & 17.6 & 529.8 & 87.6 & 521.4 & 8 & 98.4 \\
\hline
\end{tabular}




\begin{tabular}{|c|c|c|c|c|c|c|c|c|c|c|c|c|c|c|c|c|c|c|c|}
\hline Analysis & $\mathrm{U}$ & $206 \mathrm{~Pb}$ & $\mathrm{U} / \mathrm{Th}$ & $206 \mathrm{~Pb}^{*}$ & \pm & $207 \mathrm{~Pb}^{*}$ & \pm & $206 \mathrm{~Pb}^{*}$ & \pm & error & $206 \mathrm{~Pb}^{*}$ & \pm & $207 \mathrm{~Pb}^{*}$ & \pm & $206 \mathrm{~Pb}^{*}$ & \pm & $\begin{array}{c}\text { Best } \\
\text { age }\end{array}$ & \pm & Conc \\
\hline & (ppm) & $204 \mathrm{~Pb}$ & & $207 \mathrm{~Pb}^{*}$ & $(\%)$ & $235 \mathrm{U}^{*}$ & $(\%)$ & $238 \mathrm{U}$ & $(\%)$ & corr. & $238 \mathrm{U}^{*}$ & (Ma) & $235 \mathrm{U}$ & (Ma) & $207 \mathrm{~Pb}^{*}$ & (Ma) & (Ma) & (Ma) & $(\%)$ \\
\hline $\begin{array}{l}\text { 09BLC1- } \\
11\end{array}$ & 203 & 58037 & 1.0 & 17.26 & 2.2 & 0.67 & 2.4 & 0.0844 & 0.8 & 0.33 & 522.0 & 3.9 & 522.9 & 9.6 & 526.9 & 48.8 & 522.0 & 4 & 99.1 \\
\hline $\begin{array}{l}\text { 09BLC1- } \\
38\end{array}$ & 141 & 66642 & 6.2 & 17.55 & 3.4 & 0.67 & 3.7 & 0.0852 & 1.6 & 0.43 & 527.3 & 8.1 & 520.4 & 15.2 & 490.5 & 74.7 & 527.3 & 8 & 107.5 \\
\hline $\begin{array}{l}\text { 09BLC1- } \\
9\end{array}$ & 83 & 25873 & 1.5 & 18.09 & 7.6 & 0.65 & 7.8 & 0.0852 & 2.0 & 0.26 & 527.4 & 10.3 & 508.3 & 31.4 & 423.4 & 169.3 & 527.4 & 10 & 124.5 \\
\hline $\begin{array}{l}\text { 09BLC1- } \\
89\end{array}$ & 73 & 17545 & 1.3 & 17.58 & 9.0 & 0.67 & 9.2 & 0.0856 & 1.6 & 0.18 & 529.3 & 8.3 & 521.3 & 37.3 & 486.6 & 199.1 & 529.3 & 8 & 108.8 \\
\hline $\begin{array}{l}\text { 09BLC1- } \\
43\end{array}$ & 60 & 20237 & 0.8 & 18.76 & 11.2 & 0.63 & 11.3 & 0.0861 & 1.8 & 0.16 & 532.6 & 9.3 & 497.9 & 44.5 & 341.5 & 253.3 & 532.6 & 9 & 155.9 \\
\hline $\begin{array}{l}\text { 09BLC1- } \\
29\end{array}$ & 109 & 32434 & 1.8 & 16.90 & 5.1 & 0.70 & 5.7 & 0.0863 & 2.5 & 0.45 & 533.6 & 13.0 & 541.1 & 23.8 & 572.9 & 110.4 & 533.6 & 13 & 93.1 \\
\hline $\begin{array}{l}\text { 09BLC1- } \\
36\end{array}$ & 118 & 119594 & 1.8 & 17.35 & 2.3 & 0.70 & 3.0 & 0.0876 & 2.0 & 0.64 & 541.2 & 10.2 & 536.3 & 12.7 & 515.6 & 51.3 & 541.2 & 10 & 105.0 \\
\hline $\begin{array}{l}\text { 09BLC1- } \\
51\end{array}$ & 177 & 61658 & 1.8 & 16.99 & 2.1 & 0.72 & 2.7 & 0.0882 & 1.8 & 0.66 & 544.8 & 9.4 & 548.0 & 11.6 & 561.6 & 45.1 & 544.8 & 9 & 97.0 \\
\hline $\begin{array}{l}\text { 09BLC1- } \\
20\end{array}$ & 156 & 47745 & 2.4 & 17.39 & 3.8 & 0.70 & 4.1 & 0.0882 & 1.7 & 0.41 & 544.8 & 8.9 & 538.4 & 17.2 & 511.4 & 82.5 & 544.8 & 9 & 106.5 \\
\hline $\begin{array}{l}\text { 09BLC1- } \\
74\end{array}$ & 160 & 66020 & 4.7 & 17.27 & 2.8 & 0.71 & 2.9 & 0.0890 & 1.0 & 0.33 & 549.6 & 5.0 & 545.1 & 12.4 & 526.6 & 60.9 & 549.6 & 5 & 104.4 \\
\hline $\begin{array}{l}\text { 09BLC1- } \\
58\end{array}$ & 127 & 25490 & 1.4 & 17.40 & 4.1 & 0.71 & 4.6 & 0.0894 & 2.1 & 0.46 & 551.7 & 11.2 & 543.5 & 19.3 & 509.4 & 89.3 & 551.7 & 11 & 108.3 \\
\hline $\begin{array}{l}\text { 09BLC1- } \\
32\end{array}$ & 51 & 15433 & 1.5 & 18.01 & 12.4 & 0.69 & 12.6 & 0.0906 & 2.2 & 0.17 & 559.1 & 11.8 & 535.1 & 52.5 & 434.0 & 277.6 & 559.1 & 12 & 128.8 \\
\hline $\begin{array}{l}\text { 09BLC1- } \\
19\end{array}$ & 70 & 14602 & 1.9 & 17.73 & 5.6 & 0.71 & 5.9 & 0.0917 & 1.7 & 0.28 & 565.6 & 9.0 & 546.7 & 24.8 & 468.7 & 124.8 & 565.6 & 9 & 120.7 \\
\hline $\begin{array}{l}\text { 09BLC1- } \\
22\end{array}$ & 372 & 138875 & 2.1 & 16.88 & 1.1 & 0.76 & 1.5 & 0.0931 & 1.0 & 0.68 & 573.6 & 5.4 & 574.0 & 6.4 & 575.6 & 23.3 & 573.6 & 5 & 99.7 \\
\hline $\begin{array}{l}\text { 09BLC1- } \\
94\end{array}$ & 210 & 36388 & 1.4 & 16.75 & 1.7 & 0.77 & 3.2 & 0.0931 & 2.8 & 0.86 & 573.9 & 15.2 & 577.8 & 14.2 & 593.4 & 35.9 & 573.9 & 15 & 96.7 \\
\hline $\begin{array}{l}\text { 09BLC1- } \\
8\end{array}$ & 431 & 236994 & 2.7 & 16.31 & 1.8 & 0.79 & 4.0 & 0.0933 & 3.6 & 0.89 & 575.0 & 19.7 & 590.5 & 17.9 & 650.5 & 38.7 & 575.0 & 20 & 88.4 \\
\hline $\begin{array}{l}\text { 09BLC1- } \\
77\end{array}$ & 83 & 20284 & 3.5 & 16.84 & 4.5 & 0.77 & 9.2 & 0.0934 & 8.0 & 0.87 & 575.7 & 44.3 & 577.0 & 40.6 & 581.8 & 98.1 & 575.7 & 44 & 99.0 \\
\hline $\begin{array}{l}\text { 09BLC1- } \\
68\end{array}$ & 169 & 43569 & 1.5 & 16.59 & 1.6 & 0.78 & 3.2 & 0.0939 & 2.8 & 0.86 & 578.5 & 15.3 & 585.6 & 14.3 & 613.3 & 35.6 & 578.5 & 15 & 94.3 \\
\hline $\begin{array}{l}\text { 09BLC1- } \\
64\end{array}$ & 202 & 58164 & 4.5 & 16.87 & 2.3 & 0.78 & 2.4 & 0.0949 & 0.7 & 0.31 & 584.4 & 4.1 & 582.9 & 10.5 & 577.1 & 49.0 & 584.4 & 4 & 101.3 \\
\hline $\begin{array}{l}\text { 09BLC1- } \\
54\end{array}$ & 22 & 6696 & 4.8 & 18.07 & 13.4 & 0.73 & 14.2 & 0.0955 & 4.7 & 0.33 & 587.8 & 26.6 & 555.7 & 61.0 & 426.1 & 300.7 & 587.8 & 27 & 137.9 \\
\hline $\begin{array}{l}\text { 09BLC1- } \\
81\end{array}$ & 456 & 7036 & 6.4 & 16.22 & 3.1 & 0.82 & 5.1 & 0.0963 & 4.1 & 0.80 & 592.6 & 23.4 & 607.2 & 23.5 & 661.7 & 65.6 & 592.6 & 23 & 89.6 \\
\hline $\begin{array}{l}\text { 09BLC1- } \\
79\end{array}$ & 366 & 7787 & 2.0 & 16.19 & 1.0 & 0.86 & 1.6 & 0.1012 & 1.2 & 0.76 & 621.5 & 7.2 & 631.1 & 7.5 & 666.0 & 22.2 & 621.5 & 7 & 93.3 \\
\hline $\begin{array}{l}\text { 09BLC1- } \\
90\end{array}$ & 162 & 69878 & 2.9 & 16.56 & 3.3 & 0.85 & 3.5 & 0.1019 & 1.1 & 0.31 & 625.5 & 6.4 & 623.8 & 16.2 & 617.7 & 71.6 & 625.5 & 6 & 101.3 \\
\hline $\begin{array}{l}\text { 09BLC1- } \\
97\end{array}$ & 222 & 57526 & 4.0 & 15.97 & 1.6 & 0.89 & 2.2 & 0.1026 & 1.5 & 0.69 & 629.6 & 8.8 & 644.0 & 10.3 & 694.6 & 33.4 & 629.6 & 9 & 90.6 \\
\hline $\begin{array}{l}\text { 09BLC1- } \\
57\end{array}$ & 481 & 123520 & 48.5 & 16.28 & 0.9 & 0.90 & 4.4 & 0.1067 & 4.3 & 0.98 & 653.6 & 26.7 & 653.8 & 21.2 & 654.3 & 20.0 & 653.6 & 27 & 99.9 \\
\hline $\begin{array}{l}\text { 09BLC1- } \\
59\end{array}$ & 220 & 82156 & 3.8 & 15.12 & 2.9 & 1.05 & 6.2 & 0.1150 & 5.5 & 0.88 & 701.8 & 36.4 & 728.3 & 32.3 & 810.9 & 61.7 & 701.8 & 36 & 86.5 \\
\hline $\begin{array}{l}\text { 09BLC1- } \\
13\end{array}$ & 227 & 153436 & 5.2 & 15.60 & 1.4 & 1.04 & 5.3 & 0.1171 & 5.2 & 0.97 & 714.1 & 34.9 & 721.7 & 27.6 & 745.5 & 29.5 & 714.1 & 35 & 95.8 \\
\hline $\begin{array}{l}\text { 09BLC1- } \\
45\end{array}$ & 102 & 23224 & 1.1 & 15.73 & 3.4 & 1.05 & 3.6 & 0.1195 & 1.0 & 0.28 & 727.6 & 7.0 & 727.6 & 18.6 & 727.5 & 72.8 & 727.6 & 7 & 100.0 \\
\hline $\begin{array}{l}\text { 09BLC1- } \\
26\end{array}$ & 549 & 17023 & 1.8 & 15.33 & 0.8 & 1.14 & 1.7 & 0.1265 & 1.5 & 0.90 & 767.8 & 11.1 & 771.2 & 9.3 & 781.2 & 16.1 & 767.8 & 11 & 98.3 \\
\hline $\begin{array}{l}\text { 09BLC1- } \\
42\end{array}$ & 46 & 23726 & 4.6 & 13.97 & 2.7 & 1.64 & 3.5 & 0.1661 & 2.3 & 0.64 & 990.7 & 20.7 & 985.8 & 22.4 & 974.7 & 55.8 & 974.7 & 56 & 101.6 \\
\hline $\begin{array}{l}\text { 09BLC1- } \\
37\end{array}$ & 119 & 53361 & 2.4 & 13.74 & 1.6 & 1.66 & 2.6 & 0.1652 & 2.1 & 0.80 & 985.7 & 19.1 & 992.5 & 16.6 & 1007.7 & 32.2 & 1007.7 & 32 & 97.8 \\
\hline $\begin{array}{l}\text { 09BLC1- } \\
87\end{array}$ & 369 & 10460 & 1.6 & 13.48 & 1.0 & 1.77 & 1.5 & 0.1730 & 1.1 & 0.76 & 1028.4 & 10.7 & 1034.4 & 9.6 & 1047.2 & 19.5 & 1047.2 & 19 & 98.2 \\
\hline $\begin{array}{l}\text { 09BLC1- } \\
4\end{array}$ & 323 & 93625 & 1.2 & 13.43 & 0.3 & 1.84 & 2.1 & 0.1789 & 2.1 & 0.99 & 1061.2 & 20.4 & 1058.8 & 13.8 & 1053.9 & 5.0 & 1053.9 & 5 & 100.7 \\
\hline $\begin{array}{l}\text { 09BLC1- } \\
95\end{array}$ & 206 & 33083 & 2.4 & 13.19 & 2.1 & 1.83 & 7.3 & 0.1749 & 7.0 & 0.96 & 1039.0 & 66.7 & 1055.8 & 47.8 & 1090.8 & 42.8 & 1090.8 & 43 & 95.3 \\
\hline $\begin{array}{l}\text { 09BLC1- } \\
21\end{array}$ & 231 & 377967 & 2.3 & 13.13 & 1.1 & 1.97 & 1.8 & 0.1875 & 1.3 & 0.76 & 1107.8 & 13.5 & 1104.7 & 11.8 & 1098.7 & 22.9 & 1098.7 & 23 & 100.8 \\
\hline $\begin{array}{l}\text { 09BLC1- } \\
30\end{array}$ & 111 & 107136 & 1.5 & 13.12 & 1.4 & 1.89 & 3.0 & 0.1802 & 2.7 & 0.88 & 1067.8 & 26.3 & 1078.7 & 20.1 & 1100.7 & 28.2 & 1100.7 & 28 & 97.0 \\
\hline $\begin{array}{l}\text { 09BLC1- } \\
31\end{array}$ & 158 & 12975 & 2.5 & 13.05 & 1.6 & 1.92 & 2.0 & 0.1818 & 1.2 & 0.60 & 1076.7 & 11.8 & 1088.1 & 13.2 & 1111.1 & 31.6 & 1111.1 & 32 & 96.9 \\
\hline $\begin{array}{l}\text { 09BLC1- } \\
56\end{array}$ & 281 & 179213 & 5.0 & 13.04 & 0.9 & 2.04 & 2.3 & 0.1930 & 2.1 & 0.91 & 1137.8 & 21.9 & 1129.2 & 15.7 & 1112.7 & 18.9 & 1112.7 & 19 & 102.3 \\
\hline $\begin{array}{l}\text { 09BLC1- } \\
63\end{array}$ & 101 & 103702 & 1.6 & 12.88 & 1.9 & 2.03 & 3.8 & 0.1894 & 3.3 & 0.86 & 1118.2 & 33.4 & 1125.0 & 25.7 & 1138.1 & 38.4 & 1138.1 & 38 & 98.3 \\
\hline
\end{tabular}




\begin{tabular}{|c|c|c|c|c|c|c|c|c|c|c|c|c|c|c|c|c|c|c|c|}
\hline Analysis & $\mathrm{U}$ & $206 \mathrm{~Pb}$ & $\mathrm{U} / \mathrm{Th}$ & $206 \mathrm{~Pb}^{*}$ & \pm & $207 \mathrm{~Pb}^{*}$ & \pm & $206 \mathrm{~Pb}^{*}$ & \pm & error & $206 \mathrm{~Pb}^{*}$ & \pm & $207 \mathrm{~Pb}^{*}$ & \pm & $206 \mathrm{~Pb}^{*}$ & \pm & $\begin{array}{c}\text { Best } \\
\text { age }\end{array}$ & \pm & Conc \\
\hline & (ppm) & $204 \mathrm{~Pb}$ & & $207 \mathrm{~Pb}^{*}$ & $(\%)$ & $235 \mathrm{U}^{*}$ & $(\%)$ & $238 \mathrm{U}$ & $(\%)$ & corr. & $238 \mathrm{U}^{*}$ & (Ma) & $235 \mathrm{U}$ & (Ma) & $207 \mathrm{~Pb}^{*}$ & $(\mathrm{Ma})$ & (Ma) & (Ma) & $(\%)$ \\
\hline $\begin{array}{l}\text { 09BLC1- } \\
47\end{array}$ & 423 & 30085 & 1.6 & 9.71 & 0.3 & 4.08 & 1.3 & 0.2873 & 1.3 & 0.98 & 1628.0 & 18.7 & 1650.6 & 10.8 & 1679.4 & 4.9 & 1679.4 & 5 & 96.9 \\
\hline $\begin{array}{l}\text { 09BLC1- } \\
80\end{array}$ & 81 & 141751 & 0.9 & 9.24 & 1.2 & 4.71 & 1.8 & 0.3157 & 1.4 & 0.77 & 1768.7 & 21.7 & 1769.2 & 15.2 & 1769.9 & 21.0 & 1769.9 & 21 & 99.9 \\
\hline $\begin{array}{l}\text { 09BLC1- } \\
61\end{array}$ & 84 & 54778 & 1.7 & 5.27 & 0.6 & 12.64 & 3.8 & 0.4829 & 3.8 & 0.99 & 2539.7 & 79.9 & 2653.0 & 36.2 & 2740.6 & 9.6 & 2740.6 & 10 & 92.7 \\
\hline $\begin{array}{l}\text { 13ZA91- } \\
10\end{array}$ & 426 & 69711 & 1.1 & 19.42 & 3.1 & 0.30 & 3.7 & 0.0424 & 2.0 & 0.54 & 267.7 & 5.1 & 267.3 & 8.6 & 263.4 & 71.1 & 267.7 & 5 & NA \\
\hline $\begin{array}{l}\text { 13ZA91- } \\
14\end{array}$ & 305 & 53610 & 1.3 & 18.73 & 2.7 & 0.31 & 3.0 & 0.0425 & 1.3 & 0.43 & 268.1 & 3.4 & 276.2 & 7.3 & 346.0 & 61.8 & 268.1 & 3 & NA \\
\hline $\begin{array}{l}\text { 13ZA91- } \\
68\end{array}$ & 235 & 8786 & 1.4 & 19.25 & 2.6 & 0.31 & 3.2 & 0.0427 & 1.9 & 0.58 & 269.5 & 5.0 & 270.9 & 7.7 & 283.1 & 60.4 & 269.5 & 5 & NA \\
\hline $\begin{array}{l}\text { 13ZA91- } \\
51\end{array}$ & 207 & 20687 & 1.2 & 19.36 & 7.5 & 0.31 & 7.6 & 0.0429 & 1.3 & 0.17 & 270.8 & 3.4 & 270.8 & 18.2 & 270.2 & 172.8 & 270.8 & 3 & NA \\
\hline $\begin{array}{l}\text { 13ZA91- } \\
48\end{array}$ & 516 & 33640 & 1.2 & 19.13 & 2.5 & 0.31 & 3.8 & 0.0429 & 2.8 & 0.74 & 271.0 & 7.4 & 273.7 & 9.1 & 297.3 & 58.1 & 271.0 & 7 & NA \\
\hline $\begin{array}{l}\text { 13ZA91- } \\
87\end{array}$ & 151 & 23954 & 1.1 & 18.99 & 7.8 & 0.31 & 8.2 & 0.0430 & 2.4 & 0.30 & 271.4 & 6.5 & 275.8 & 19.8 & 313.9 & 178.1 & 271.4 & 6 & NA \\
\hline $\begin{array}{l}\text { 13ZA91- } \\
66 \\
\end{array}$ & 349 & 40483 & 1.1 & 19.58 & 3.5 & 0.30 & 3.9 & 0.0432 & 1.7 & 0.44 & 272.4 & 4.6 & 269.4 & 9.2 & 243.8 & 80.0 & 272.4 & 5 & NA \\
\hline $\begin{array}{l}\text { 13ZA91- } \\
89\end{array}$ & 301 & 20745 & 0.9 & 18.88 & 5.7 & 0.32 & 6.1 & 0.0433 & 2.2 & 0.36 & 273.4 & 5.9 & 279.1 & 14.9 & 327.1 & 128.8 & 273.4 & 6 & NA \\
\hline $\begin{array}{l}\text { 13ZA91- } \\
97\end{array}$ & 260 & 9414 & 0.9 & 19.41 & 3.6 & 0.31 & 4.3 & 0.0433 & 2.3 & 0.54 & 273.4 & 6.2 & 272.4 & 10.2 & 263.7 & 82.9 & 273.4 & 6 & NA \\
\hline $\begin{array}{l}\text { 13ZA91- } \\
80\end{array}$ & 211 & 19390 & 1.0 & 18.73 & 5.1 & 0.32 & 5.2 & 0.0434 & 1.2 & 0.22 & 273.7 & 3.1 & 281.3 & 12.8 & 344.8 & 115.4 & 273.7 & 3 & NA \\
\hline $\begin{array}{l}\text { 13ZA91- } \\
92\end{array}$ & 453 & 147542 & 0.9 & 18.87 & 2.2 & 0.32 & 3.3 & 0.0434 & 2.5 & 0.76 & 274.0 & 6.7 & 279.8 & 8.1 & 328.8 & 49.4 & 274.0 & 7 & NA \\
\hline $\begin{array}{l}\text { 13ZA91- } \\
34 \\
\end{array}$ & 525 & 15437 & 1.4 & 18.61 & 1.7 & 0.32 & 2.4 & 0.0434 & 1.7 & 0.70 & 274.0 & 4.6 & 283.1 & 6.0 & 359.4 & 39.1 & 274.0 & 5 & NA \\
\hline $\begin{array}{l}\text { 13ZA91- } \\
86\end{array}$ & 213 & 13353 & 1.2 & 19.06 & 3.6 & 0.31 & 4.1 & 0.0434 & 2.0 & 0.47 & 274.2 & 5.3 & 277.5 & 10.1 & 305.9 & 83.0 & 274.2 & 5 & NA \\
\hline $\begin{array}{l}\text { 13ZA91- } \\
41\end{array}$ & 161 & 4040 & 1.6 & 20.52 & 11.5 & 0.29 & 11.7 & 0.0435 & 1.8 & 0.15 & 274.4 & 4.8 & 260.3 & 26.8 & 135.4 & 271.7 & 274.4 & 5 & NA \\
\hline $\begin{array}{l}\text { 13ZA91- } \\
58\end{array}$ & 100 & 11826 & 1.0 & 18.66 & 9.6 & 0.32 & 9.9 & 0.0435 & 2.4 & 0.24 & 274.7 & 6.4 & 283.2 & 24.4 & 354.5 & 216.4 & 274.7 & 6 & NA \\
\hline $\begin{array}{l}\text { 13ZA91- } \\
61 \\
\end{array}$ & 279 & 72908 & 1.9 & 18.89 & 1.8 & 0.32 & 2.0 & 0.0435 & 0.9 & 0.44 & 274.7 & 2.4 & 280.3 & 4.9 & 326.6 & 41.0 & 274.7 & 2 & NA \\
\hline $\begin{array}{l}\text { 13ZA91- } \\
100\end{array}$ & 328 & 41796 & 0.9 & 19.63 & 1.9 & 0.31 & 2.4 & 0.0436 & 1.5 & 0.63 & 275.2 & 4.1 & 271.4 & 5.7 & 238.7 & 43.2 & 275.2 & 4 & NA \\
\hline $\begin{array}{l}\text { 13ZA91- } \\
70\end{array}$ & 137 & 1803 & 0.9 & 19.65 & 7.9 & 0.31 & 8.2 & 0.0437 & 2.2 & 0.26 & 275.8 & 5.8 & 271.6 & 19.5 & 235.9 & 182.5 & 275.8 & 6 & NA \\
\hline $\begin{array}{l}\text { 13ZA91- } \\
71\end{array}$ & 298 & 26825 & 1.1 & 19.45 & 6.5 & 0.31 & 6.7 & 0.0438 & 1.6 & 0.24 & 276.3 & 4.3 & 274.6 & 16.0 & 259.7 & 148.4 & 276.3 & 4 & NA \\
\hline $\begin{array}{l}\text { 13ZA91- } \\
96\end{array}$ & 216 & 28446 & 0.7 & 19.97 & 4.5 & 0.30 & 6.0 & 0.0440 & 3.9 & 0.65 & 277.4 & 10.6 & 269.2 & 14.1 & 198.8 & 105.2 & 277.4 & 11 & NA \\
\hline $\begin{array}{l}\text { 13ZA91- } \\
67\end{array}$ & 65 & 9723 & 0.9 & 19.51 & 15.9 & 0.31 & 16.6 & 0.0442 & 4.8 & 0.29 & 278.6 & 13.0 & 275.7 & 40.1 & 251.8 & 368.0 & 278.6 & 13 & NA \\
\hline $\begin{array}{l}\text { 13ZA91- } \\
50\end{array}$ & 168 & 2913 & 1.3 & 17.67 & 9.5 & 0.35 & 9.6 & 0.0445 & 1.5 & 0.15 & 280.6 & 4.0 & 302.5 & 25.1 & 475.3 & 210.5 & 280.6 & 4 & NA \\
\hline $\begin{array}{l}\text { 13ZA91- } \\
81\end{array}$ & 136 & 38045 & 1.1 & 19.92 & 10.7 & 0.31 & 11.3 & 0.0446 & 3.8 & 0.33 & 281.2 & 10.4 & 273.1 & 27.2 & 204.3 & 248.8 & 281.2 & 10 & NA \\
\hline $\begin{array}{l}\text { 13ZA91- } \\
47\end{array}$ & 245 & 18662 & 1.1 & 19.39 & 4.0 & 0.32 & 4.4 & 0.0446 & 1.7 & 0.39 & 281.3 & 4.7 & 279.7 & 10.7 & 266.3 & 92.5 & 281.3 & 5 & NA \\
\hline $\begin{array}{l}\text { 13ZA91- } \\
15\end{array}$ & 522 & 77228 & 0.9 & 19.38 & 2.6 & 0.32 & 4.2 & 0.0446 & 3.2 & 0.78 & 281.5 & 8.9 & 280.0 & 10.2 & 267.2 & 60.7 & 281.5 & 9 & NA \\
\hline $\begin{array}{l}\text { 13ZA91- } \\
90\end{array}$ & 192 & 13444 & 1.0 & 18.25 & 10.9 & 0.34 & 11.1 & 0.0454 & 2.2 & 0.20 & 286.5 & 6.3 & 299.7 & 28.9 & 403.8 & 244.6 & 286.5 & 6 & NA \\
\hline $\begin{array}{l}\text { 13ZA91- } \\
22\end{array}$ & 95 & 16410 & 1.3 & 18.16 & 12.4 & 0.35 & 12.7 & 0.0463 & 2.8 & 0.22 & 291.9 & 8.0 & 305.9 & 33.6 & 414.3 & 278.2 & 291.9 & 8 & NA \\
\hline $\begin{array}{l}\text { 13ZA91- } \\
32\end{array}$ & 133 & 25484 & 1.1 & 19.22 & 8.6 & 0.33 & 8.8 & 0.0467 & 1.7 & 0.20 & 294.2 & 5.0 & 293.3 & 22.4 & 286.5 & 197.0 & 294.2 & 5 & NA \\
\hline $\begin{array}{l}\text { 13ZA91- } \\
43\end{array}$ & 238 & 21839 & 1.4 & 19.29 & 5.1 & 0.34 & 6.3 & 0.0470 & 3.6 & 0.58 & 295.8 & 10.5 & 293.9 & 16.0 & 278.6 & 117.4 & 295.8 & 11 & NA \\
\hline $\begin{array}{l}\text { 13ZA91- } \\
91\end{array}$ & 316 & 79760 & 2.0 & 18.84 & 3.3 & 0.35 & 4.3 & 0.0484 & 2.6 & 0.62 & 304.6 & 7.8 & 307.7 & 11.3 & 331.8 & 75.8 & 304.6 & 8 & NA \\
\hline $\begin{array}{l}\text { 13ZA91- } \\
64\end{array}$ & 129 & 9853 & 0.6 & 19.55 & 5.3 & 0.35 & 6.0 & 0.0493 & 2.8 & 0.47 & 310.2 & 8.6 & 303.1 & 15.7 & 248.2 & 121.7 & 310.2 & 9 & NA \\
\hline $\begin{array}{l}\text { 13ZA91- } \\
69\end{array}$ & 178 & 14440 & 1.3 & 18.19 & 6.1 & 0.38 & 6.4 & 0.0497 & 2.0 & 0.31 & 312.4 & 6.0 & 324.4 & 17.7 & 411.6 & 135.4 & 312.4 & 6 & NA \\
\hline $\begin{array}{l}\text { 13ZA91- } \\
4\end{array}$ & 275 & 39485 & 1.1 & 18.83 & 3.2 & 0.37 & 3.9 & 0.0504 & 2.2 & 0.57 & 317.0 & 6.9 & 318.9 & 10.6 & 332.8 & 71.9 & 317.0 & 7 & NA \\
\hline $\begin{array}{l}\text { 13ZA91- } \\
6\end{array}$ & 179 & 44722 & 1.8 & 16.10 & 2.6 & 0.53 & 3.9 & 0.0613 & 2.8 & 0.73 & 383.6 & 10.5 & 428.6 & 13.5 & 678.2 & 56.2 & 383.6 & 10 & NA \\
\hline $\begin{array}{l}\text { 13ZA91- } \\
94\end{array}$ & 382 & 6628 & 2.0 & 17.88 & 3.6 & 0.48 & 4.4 & 0.0617 & 2.6 & 0.57 & 385.7 & 9.6 & 395.1 & 14.6 & 450.0 & 80.8 & 385.7 & 10 & NA \\
\hline $\begin{array}{l}\text { 13ZA91- } \\
5\end{array}$ & 302 & 61256 & 12.9 & 17.68 & 1.7 & 0.51 & 2.0 & 0.0652 & 1.1 & 0.56 & 407.3 & 4.5 & 417.5 & 7.0 & 474.5 & 37.6 & 407.3 & 4 & 85.8 \\
\hline
\end{tabular}




\begin{tabular}{|c|c|c|c|c|c|c|c|c|c|c|c|c|c|c|c|c|c|c|c|}
\hline Analysis & $\mathrm{U}$ & $206 \mathrm{~Pb}$ & $\mathrm{U} / \mathrm{Th}$ & $206 \mathrm{~Pb}^{*}$ & \pm & $207 \mathrm{~Pb}^{*}$ & \pm & $206 \mathrm{~Pb}^{*}$ & \pm & error & $206 \mathrm{~Pb}^{*}$ & \pm & $207 \mathrm{~Pb}^{*}$ & \pm & $206 \mathrm{~Pb}^{*}$ & \pm & $\begin{array}{c}\text { Best } \\
\text { age }\end{array}$ & \pm & Conc \\
\hline & (ppm) & $204 \mathrm{~Pb}$ & & $207 \mathrm{~Pb}^{*}$ & $(\%)$ & $235 \mathrm{U}^{*}$ & $(\%)$ & $238 \mathrm{U}$ & $(\%)$ & corr. & $238 \mathrm{U}^{*}$ & (Ma) & $235 \mathrm{U}$ & (Ma) & $207 \mathrm{~Pb}^{*}$ & (Ma) & (Ma) & (Ma) & (\%) \\
\hline $\begin{array}{l}\text { 13ZA91- } \\
18\end{array}$ & 115 & 16113 & 2.0 & 17.70 & 4.1 & 0.51 & 4.4 & 0.0657 & 1.7 & 0.38 & 410.0 & 6.6 & 419.4 & 15.2 & 471.8 & 90.9 & 410.0 & 7 & 86.9 \\
\hline $\begin{array}{l}\text { 13ZA91- } \\
24\end{array}$ & 317 & 3368 & 3.4 & 17.43 & 6.4 & 0.53 & 6.6 & 0.0671 & 1.5 & 0.23 & 418.8 & 6.2 & 432.5 & 23.3 & 505.7 & 141.9 & 418.8 & 6 & 82.8 \\
\hline $\begin{array}{l}\text { 13ZA91- } \\
74\end{array}$ & 350 & 62561 & 8.2 & 17.82 & 1.5 & 0.55 & 5.7 & 0.0710 & 5.5 & 0.97 & 442.1 & 23.6 & 444.5 & 20.5 & 457.2 & 32.4 & 442.1 & 24 & 96.7 \\
\hline $\begin{array}{l}\text { 13ZA91- } \\
35\end{array}$ & 145 & 33026 & 1.3 & 17.37 & 3.1 & 0.59 & 3.9 & 0.0746 & 2.4 & 0.62 & 463.7 & 10.9 & 472.2 & 14.9 & 513.8 & 68.0 & 463.7 & 11 & 90.2 \\
\hline $\begin{array}{l}\text { 13ZA91- } \\
13\end{array}$ & 331 & 46197 & 1.8 & 17.72 & 1.7 & 0.59 & 2.5 & 0.0759 & 1.8 & 0.73 & 471.7 & 8.3 & 471.4 & 9.4 & 469.9 & 37.6 & 471.7 & 8 & 100.4 \\
\hline $\begin{array}{l}\text { 13ZA91- } \\
8\end{array}$ & 204 & 43029 & 1.4 & 17.87 & 4.1 & 0.59 & 4.4 & 0.0760 & 1.6 & 0.36 & 472.1 & 7.3 & 468.6 & 16.6 & 451.4 & 91.7 & 472.1 & 7 & 104.6 \\
\hline $\begin{array}{l}\text { 13ZA91- } \\
20\end{array}$ & 661 & 119378 & 15.1 & 17.34 & 1.3 & 0.61 & 2.2 & 0.0764 & 1.7 & 0.81 & 474.8 & 8.0 & 482.1 & 8.3 & 517.0 & 27.9 & 474.8 & 8 & 91.8 \\
\hline $\begin{array}{l}\text { 13ZA91- } \\
59\end{array}$ & 176 & 18510 & 0.7 & 17.69 & 5.0 & 0.60 & 5.1 & 0.0771 & 0.9 & 0.18 & 478.7 & 4.1 & 477.7 & 19.4 & 472.8 & 111.1 & 478.7 & 4 & 101.2 \\
\hline $\begin{array}{l}\text { 13ZA91- } \\
75\end{array}$ & 295 & 48444 & 1.5 & 17.75 & 1.6 & 0.60 & 2.1 & 0.0772 & 1.3 & 0.63 & 479.4 & 6.1 & 477.1 & 7.9 & 465.9 & 35.8 & 479.4 & 6 & 102.9 \\
\hline $\begin{array}{l}\text { 13ZA91- } \\
42\end{array}$ & 240 & 45391 & 1.8 & 17.97 & 3.2 & 0.59 & 3.5 & 0.0774 & 1.3 & 0.36 & 480.9 & 5.9 & 473.6 & 13.2 & 438.6 & 72.2 & 480.9 & 6 & 109.6 \\
\hline $\begin{array}{l}\text { 13ZA91- } \\
83\end{array}$ & 84 & 12026 & 1.2 & 17.49 & 9.8 & 0.61 & 10.0 & 0.0775 & 2.3 & 0.23 & 481.1 & 10.9 & 484.0 & 38.7 & 497.9 & 215.5 & 481.1 & 11 & 96.6 \\
\hline $\begin{array}{l}\text { 13ZA91- } \\
16\end{array}$ & 140 & 32778 & 2.4 & 17.26 & 4.3 & 0.62 & 4.8 & 0.0777 & 2.2 & 0.46 & 482.4 & 10.3 & 490.3 & 18.7 & 527.5 & 93.7 & 482.4 & 10 & 91.4 \\
\hline $\begin{array}{l}\text { 13ZA91- } \\
49\end{array}$ & 305 & 9937 & 3.1 & 17.43 & 3.1 & 0.62 & 5.4 & 0.0783 & 4.4 & 0.82 & 485.8 & 20.6 & 489.4 & 20.9 & 506.3 & 67.8 & 485.8 & 21 & 95.9 \\
\hline $\begin{array}{l}\text { 13ZA91- } \\
76\end{array}$ & 148 & 13014 & 1.4 & 17.52 & 1.8 & 0.62 & 2.5 & 0.0786 & 1.8 & 0.69 & 487.9 & 8.2 & 489.1 & 9.8 & 494.7 & 40.3 & 487.9 & 8 & 98.6 \\
\hline $\begin{array}{l}\text { 13ZA91- } \\
39\end{array}$ & 201 & 10864 & 1.6 & 17.85 & 4.4 & 0.61 & 4.6 & 0.0789 & 1.1 & 0.24 & 489.4 & 5.2 & 483.2 & 17.5 & 453.9 & 98.2 & 489.4 & 5 & 107.8 \\
\hline $\begin{array}{l}\text { 13ZA91- } \\
63\end{array}$ & 112 & 10571 & 2.8 & 17.62 & 6.0 & 0.62 & 8.7 & 0.0790 & 6.3 & 0.73 & 490.1 & 29.7 & 488.6 & 33.6 & 481.8 & 131.7 & 490.1 & 30 & 101.7 \\
\hline $\begin{array}{l}\text { 13ZA91- } \\
30\end{array}$ & 164 & 23624 & 1.6 & 17.05 & 4.3 & 0.65 & 5.8 & 0.0809 & 3.9 & 0.67 & 501.2 & 18.7 & 510.9 & 23.3 & 554.3 & 94.4 & 501.2 & 19 & 90.4 \\
\hline $\begin{array}{l}\text { 13ZA91- } \\
73\end{array}$ & 132 & 27844 & 1.7 & 17.46 & 5.4 & 0.66 & 6.6 & 0.0835 & 3.7 & 0.57 & 516.8 & 18.4 & 514.1 & 26.5 & 502.4 & 119.1 & 516.8 & 18 & 102.9 \\
\hline $\begin{array}{l}\text { 13ZA91- } \\
56 \\
\end{array}$ & 197 & 3127 & 1.8 & 16.73 & 2.7 & 0.72 & 3.0 & 0.0874 & 1.4 & 0.46 & 540.2 & 7.2 & 550.8 & 12.9 & 594.9 & 58.5 & 540.2 & 7 & 90.8 \\
\hline $\begin{array}{l}\text { 13ZA91- } \\
31\end{array}$ & 62 & 18605 & 1.9 & 16.68 & 9.7 & 0.73 & 9.8 & 0.0884 & 1.4 & 0.14 & 546.0 & 7.1 & 557.0 & 42.2 & 602.5 & 211.3 & 546.0 & 7 & 90.6 \\
\hline $\begin{array}{l}\text { 13ZA91- } \\
85 \\
\end{array}$ & 263 & 50943 & 0.9 & 17.33 & 2.0 & 0.71 & 2.7 & 0.0886 & 1.9 & 0.69 & 547.4 & 9.9 & 541.8 & 11.4 & 518.0 & 43.0 & 547.4 & 10 & 105.7 \\
\hline $\begin{array}{l}\text { 13ZA91- } \\
25\end{array}$ & 211 & 9883 & 0.7 & 16.43 & 3.3 & 0.75 & 5.7 & 0.0891 & 4.6 & 0.81 & 550.2 & 24.4 & 566.8 & 24.8 & 634.1 & 72.0 & 550.2 & 24 & 86.8 \\
\hline $\begin{array}{l}\text { 13ZA91- } \\
6\end{array}$ & 558 & 166380 & 4.1 & 16.94 & 0.8 & 0.73 & 1.8 & 0.0891 & 1.6 & 0.88 & 550.4 & 8.3 & 554.0 & 7.6 & 568.7 & 18.4 & 550.4 & 8 & 96.8 \\
\hline $\begin{array}{l}\text { 13ZA91- } \\
72\end{array}$ & 340 & 2778 & 2.6 & 16.78 & 4.0 & 0.74 & 4.2 & 0.0898 & 1.2 & 0.29 & 554.3 & 6.5 & 561.2 & 18.2 & 589.0 & 87.7 & 554.3 & 7 & 94.1 \\
\hline $\begin{array}{l}\text { 13ZA91- } \\
12\end{array}$ & 250 & 66116 & 1.9 & 17.05 & 2.0 & 0.73 & 2.1 & 0.0902 & 0.7 & 0.33 & 556.9 & 3.8 & 556.4 & 9.1 & 554.3 & 43.9 & 556.9 & 4 & 100.5 \\
\hline $\begin{array}{l}\text { 13ZA91- } \\
79\end{array}$ & 170 & 33852 & 1.6 & 17.15 & 3.2 & 0.74 & 3.3 & 0.0916 & 0.9 & 0.26 & 565.1 & 4.6 & 560.3 & 14.1 & 541.2 & 69.1 & 565.1 & 5 & 104.4 \\
\hline $\begin{array}{l}\text { 13ZA91- } \\
60\end{array}$ & 126 & 28478 & 1.4 & 17.29 & 1.6 & 0.74 & 3.2 & 0.0934 & 2.8 & 0.87 & 575.6 & 15.4 & 565.3 & 14.0 & 523.9 & 35.1 & 575.6 & 15 & 109.9 \\
\hline $\begin{array}{l}\text { 13ZA91- } \\
77\end{array}$ & 350 & 93478 & 10.4 & 15.61 & 4.2 & 0.84 & 7.3 & 0.0949 & 6.0 & 0.82 & 584.6 & 33.6 & 618.3 & 33.9 & 743.7 & 88.0 & 584.6 & 34 & 78.6 \\
\hline $\begin{array}{l}\text { 13ZA91- } \\
78\end{array}$ & 137 & 51763 & 3.0 & 16.62 & 4.3 & 0.80 & 4.7 & 0.0960 & 1.8 & 0.39 & 590.8 & 10.2 & 594.7 & 21.1 & 609.7 & 93.4 & 590.8 & 10 & 96.9 \\
\hline $\begin{array}{l}\text { 13ZA91- } \\
21\end{array}$ & 366 & 153879 & 2.8 & 16.35 & 0.9 & 0.88 & 1.4 & 0.1047 & 1.1 & 0.77 & 641.9 & 6.6 & 642.6 & 6.8 & 645.1 & 19.6 & 641.9 & 7 & 99.5 \\
\hline $\begin{array}{l}\text { 13ZA91- } \\
99\end{array}$ & 195 & 20095 & 1.8 & 16.41 & 2.1 & 0.88 & 6.0 & 0.1047 & 5.7 & 0.94 & 642.0 & 34.6 & 641.1 & 28.7 & 637.7 & 45.3 & 642.0 & 35 & 100.7 \\
\hline $\begin{array}{l}\text { 13ZA91- } \\
23\end{array}$ & 209 & 91666 & 1.4 & 15.56 & 1.7 & 0.93 & 3.4 & 0.1053 & 2.9 & 0.86 & 645.1 & 18.0 & 669.0 & 16.6 & 750.0 & 36.0 & 645.1 & 18 & 86.0 \\
\hline $\begin{array}{l}\text { 13ZA91- } \\
3\end{array}$ & 113 & 35041 & 1.7 & 15.44 & 2.7 & 0.97 & 6.7 & 0.1088 & 6.1 & 0.91 & 666.0 & 38.4 & 689.4 & 33.3 & 766.2 & 57.7 & 666.0 & 38 & 86.9 \\
\hline $\begin{array}{l}\text { 13ZA91- } \\
62\end{array}$ & 143 & 98091 & 1.7 & 15.92 & 1.1 & 0.95 & 5.3 & 0.1094 & 5.2 & 0.98 & 669.0 & 32.9 & 676.7 & 26.1 & 702.3 & 23.6 & 669.0 & 33 & 95.3 \\
\hline $\begin{array}{l}\text { 13ZA91- } \\
9\end{array}$ & 336 & 38937 & 1.7 & 15.97 & 1.1 & 0.94 & 1.7 & 0.1095 & 1.3 & 0.75 & 669.7 & 8.2 & 675.5 & 8.5 & 694.9 & 24.0 & 669.7 & 8 & 96.4 \\
\hline $\begin{array}{l}\text { 13ZA91- } \\
57\end{array}$ & 285 & 5737 & 5.0 & 14.62 & 4.2 & 1.14 & 5.2 & 0.1207 & 3.0 & 0.58 & 734.3 & 20.7 & 771.4 & 28.0 & 880.2 & 87.5 & 734.3 & 21 & 83.4 \\
\hline $\begin{array}{l}\text { 13ZA91- } \\
28\end{array}$ & 242 & 53911 & 2.4 & 15.32 & 1.2 & 1.16 & 3.6 & 0.1288 & 3.4 & 0.94 & 781.0 & 25.1 & 781.6 & 19.8 & 783.3 & 26.2 & 781.0 & 25 & 99.7 \\
\hline $\begin{array}{l}\text { 13ZA91- } \\
37\end{array}$ & 144 & 49478 & 1.8 & 14.59 & 3.3 & 1.25 & 5.0 & 0.1318 & 3.7 & 0.74 & 798.0 & 27.5 & 821.2 & 27.9 & 884.7 & 69.1 & 798.0 & 28 & 90.2 \\
\hline $\begin{array}{l}\text { 13ZA91- } \\
55\end{array}$ & 188 & 151023 & 4.4 & 14.46 & 1.6 & 1.30 & 4.7 & 0.1361 & 4.4 & 0.94 & 822.4 & 34.1 & 844.6 & 26.9 & 903.4 & 32.1 & 822.4 & 34 & 91.0 \\
\hline
\end{tabular}




\begin{tabular}{|c|c|c|c|c|c|c|c|c|c|c|c|c|c|c|c|c|c|c|c|}
\hline Analysis & $\mathrm{U}$ & $206 \mathrm{~Pb}$ & $\mathrm{U} / \mathrm{Th}$ & $206 \mathrm{~Pb}^{*}$ & \pm & $207 \mathrm{~Pb}^{*}$ & \pm & $206 \mathrm{~Pb}^{*}$ & \pm & error & $206 \mathrm{~Pb}^{*}$ & \pm & $207 \mathrm{~Pb}^{*}$ & \pm & $206 \mathrm{~Pb}^{*}$ & \pm & $\begin{array}{c}\text { Best } \\
\text { age }\end{array}$ & \pm & Conc \\
\hline & (ppm) & $204 \mathrm{~Pb}$ & & $207 \mathrm{~Pb}^{*}$ & (\%) & $235 \mathrm{U}^{*}$ & (\%) & $238 \mathrm{U}$ & $(\%)$ & corr. & $238 \mathrm{U}^{*}$ & (Ma) & $235 \mathrm{U}$ & (Ma) & $207 \mathrm{~Pb}^{*}$ & (Ma) & (Ma) & (Ma) & $(\%)$ \\
\hline $\begin{array}{l}\text { 13ZA91- } \\
36\end{array}$ & 104 & 37223 & 1.1 & 14.58 & 2.5 & 1.38 & 3.1 & 0.1463 & 1.8 & 0.60 & 880.1 & 15.0 & 882.0 & 18.0 & 886.7 & 50.8 & 880.1 & 15 & 99.3 \\
\hline $\begin{array}{l}\text { 13ZA91- } \\
93\end{array}$ & 135 & 18375 & 1.9 & 13.62 & 2.8 & 1.74 & 4.7 & 0.1715 & 3.7 & 0.80 & 1020.5 & 35.2 & 1022.1 & 30.0 & 1025.3 & 56.4 & 1025.3 & 56 & 99.5 \\
\hline $\begin{array}{l}\text { 13ZA91- } \\
45\end{array}$ & 140 & 83918 & 1.9 & 13.62 & 1.5 & 1.41 & 2.8 & 0.1395 & 2.4 & 0.84 & 841.8 & 18.8 & 894.2 & 16.7 & 1026.1 & 30.5 & 1026.1 & 30 & 82.0 \\
\hline $\begin{array}{l}\text { 13ZA91- } \\
82\end{array}$ & 137 & 86216 & 1.9 & 13.51 & 1.3 & 1.81 & 1.9 & 0.1775 & 1.4 & 0.73 & 1053.2 & 13.7 & 1049.6 & 12.7 & 1042.2 & 27.0 & 1042.2 & 27 & 101.1 \\
\hline $\begin{array}{l}\text { 13ZA91- } \\
52\end{array}$ & 135 & 7034 & 0.7 & 13.29 & 1.5 & 1.84 & 2.4 & 0.1772 & 1.9 & 0.78 & 1051.9 & 18.2 & 1059.5 & 15.8 & 1075.3 & 30.1 & 1075.3 & 30 & 97.8 \\
\hline $\begin{array}{l}\text { 13ZA91- } \\
33\end{array}$ & 130 & 133472 & 3.1 & 13.26 & 1.5 & 1.91 & 3.9 & 0.1840 & 3.6 & 0.92 & 1088.6 & 35.8 & 1085.6 & 25.9 & 1079.5 & 30.3 & 1079.5 & 30 & 100.8 \\
\hline $\begin{array}{l}\text { 13ZA91- } \\
53\end{array}$ & 291 & 100068 & 4.1 & 13.23 & 0.8 & 1.88 & 1.9 & 0.1807 & 1.7 & 0.91 & 1070.6 & 17.1 & 1075.1 & 12.6 & 1084.4 & 15.9 & 1084.4 & 16 & 98.7 \\
\hline $\begin{array}{l}\text { 13ZA91- } \\
7\end{array}$ & 174 & 108331 & 2.4 & 13.13 & 1.7 & 1.93 & 4.5 & 0.1836 & 4.2 & 0.93 & 1086.6 & 42.2 & 1090.7 & 30.4 & 1098.9 & 33.7 & 1098.9 & 34 & 98.9 \\
\hline $\begin{array}{l}\text { 13ZA91- } \\
38\end{array}$ & 35 & 24184 & 1.0 & 13.10 & 5.9 & 1.99 & 6.3 & 0.1890 & 2.0 & 0.32 & 1115.8 & 20.5 & 1111.5 & 42.3 & 1103.2 & 118.6 & 1103.2 & 118 & 101.1 \\
\hline $\begin{array}{l}\text { 13ZA91- } \\
98\end{array}$ & 145 & 24031 & 1.7 & 12.83 & 1.2 & 2.05 & 2.5 & 0.1906 & 2.2 & 0.87 & 1124.7 & 23.0 & 1131.9 & 17.4 & 1145.6 & 24.6 & 1145.6 & 25 & 98.2 \\
\hline $\begin{array}{l}\text { 13ZA91- } \\
19\end{array}$ & 158 & 124408 & 2.1 & 12.67 & 2.3 & 1.96 & 6.1 & 0.1804 & 5.6 & 0.93 & 1069.4 & 55.4 & 1103.2 & 40.9 & 1170.5 & 45.5 & 1170.5 & 46 & 91.4 \\
\hline $\begin{array}{l}\text { 13ZA91- } \\
1\end{array}$ & 85 & 31445 & 1.4 & 12.51 & 1.5 & 2.26 & 2.0 & 0.2047 & 1.4 & 0.67 & 1200.4 & 14.8 & 1198.7 & 14.3 & 1195.6 & 29.8 & 1195.6 & 30 & 100.4 \\
\hline $\begin{array}{l}\text { 13ZA91- } \\
54\end{array}$ & 130 & 21515 & 1.3 & 12.40 & 0.7 & 2.33 & 2.0 & 0.2095 & 1.9 & 0.93 & 1226.2 & 20.8 & 1221.2 & 14.2 & 1212.4 & 14.6 & 1212.4 & 15 & 101.1 \\
\hline $\begin{array}{l}\text { 13ZA91- } \\
44\end{array}$ & 163 & 6129 & 1.3 & 11.93 & 3.8 & 2.41 & 5.8 & 0.2087 & 4.3 & 0.75 & 1222.0 & 48.3 & 1246.4 & 41.4 & 1288.8 & 73.9 & 1288.8 & 74 & 94.8 \\
\hline $\begin{array}{l}\text { 12ZA93- } \\
73\end{array}$ & 192 & 21671 & 0.8 & 19.35 & 7.2 & 0.29 & 7.8 & 0.0410 & 2.9 & 0.37 & 259.2 & 7.4 & 260.4 & 17.9 & 271.0 & 165.6 & 259.2 & 7.4 & NA \\
\hline $\begin{array}{l}\text { 12ZA93- } \\
90\end{array}$ & 169 & 94263 & 0.7 & 20.75 & 5.1 & 0.27 & 5.7 & 0.0412 & 2.7 & 0.47 & 260.3 & 6.8 & 245.7 & 12.5 & 109.2 & 119.5 & 260.3 & 6.8 & NA \\
\hline $\begin{array}{l}\text { 12ZA93- } \\
87\end{array}$ & 635 & 119887 & 2.4 & 19.34 & 1.7 & 0.30 & 1.8 & 0.0415 & 0.6 & 0.32 & 261.9 & 1.5 & 262.9 & 4.2 & 272.0 & 39.0 & 261.9 & 1.5 & NA \\
\hline $\begin{array}{l}\text { 12ZA93- } \\
99\end{array}$ & 576 & 2212 & 0.7 & 18.81 & 3.2 & 0.31 & 3.5 & 0.0420 & 1.3 & 0.37 & 265.1 & 3.4 & 272.4 & 8.3 & 335.4 & 73.6 & 265.1 & 3.4 & NA \\
\hline $\begin{array}{l}\text { 12ZA93- } \\
7\end{array}$ & 345 & 4771 & 0.8 & 19.18 & 2.8 & 0.30 & 2.9 & 0.0421 & 0.7 & 0.25 & 265.6 & 1.9 & 268.2 & 6.9 & 290.9 & 65.1 & 265.6 & 1.9 & NA \\
\hline $\begin{array}{l}\text { 12ZA93- } \\
31\end{array}$ & 208 & 4134 & 0.7 & 18.33 & 10.0 & 0.32 & 10.1 & 0.0422 & 1.8 & 0.18 & 266.7 & 4.8 & 280.2 & 24.8 & 394.4 & 224.3 & 266.7 & 4.8 & NA \\
\hline $\begin{array}{l}\text { 12ZA93- } \\
89\end{array}$ & 106 & 9651 & 0.7 & 20.13 & 15.4 & 0.29 & 15.7 & 0.0422 & 3.0 & 0.19 & 266.8 & 7.8 & 258.1 & 35.8 & 180.0 & 361.1 & 266.8 & 7.8 & NA \\
\hline $\begin{array}{l}\text { 12ZA93- } \\
8\end{array}$ & 156 & 22365 & 0.9 & 19.13 & 5.2 & 0.30 & 5.8 & 0.0422 & 2.5 & 0.43 & 266.8 & 6.5 & 270.0 & 13.7 & 297.8 & 119.4 & 266.8 & 6.5 & NA \\
\hline $\begin{array}{l}\text { 12ZA93- } \\
74\end{array}$ & 707 & 16580 & 2.7 & 19.15 & 2.3 & 0.31 & 2.5 & 0.0428 & 0.7 & 0.30 & 270.4 & 1.9 & 273.0 & 5.9 & 295.3 & 53.7 & 270.4 & 1.9 & NA \\
\hline $\begin{array}{l}\text { 12ZA93- } \\
42\end{array}$ & 128 & 1965 & 1.1 & 17.74 & 12.4 & 0.33 & 12.6 & 0.0429 & 2.2 & 0.18 & 270.6 & 5.9 & 292.1 & 32.1 & 467.4 & 276.4 & 270.6 & 5.9 & NA \\
\hline $\begin{array}{l}\text { 12ZA93- } \\
62 \\
\end{array}$ & 511 & 60594 & 19.4 & 18.71 & 2.1 & 0.32 & 4.8 & 0.0429 & 4.3 & 0.90 & 271.0 & 11.3 & 279.1 & 11.6 & 347.3 & 47.6 & 271.0 & 11.3 & NA \\
\hline $\begin{array}{l}\text { 12ZA93- } \\
24\end{array}$ & 352 & 10002 & 1.3 & 19.09 & 3.5 & 0.32 & 4.2 & 0.0438 & 2.3 & 0.55 & 276.1 & 6.2 & 278.8 & 10.2 & 301.8 & 79.7 & 276.1 & 6.2 & NA \\
\hline $\begin{array}{l}\text { 12ZA93- } \\
65\end{array}$ & 204 & 12318 & 0.8 & 18.74 & 4.9 & 0.32 & 5.2 & 0.0438 & 1.8 & 0.35 & 276.3 & 5.0 & 283.5 & 13.0 & 343.7 & 111.3 & 276.3 & 5.0 & NA \\
\hline $\begin{array}{l}\text { 12ZA93- } \\
77\end{array}$ & 252 & 14968 & 0.7 & 19.07 & 6.1 & 0.32 & 6.1 & 0.0439 & 0.9 & 0.14 & 276.7 & 2.3 & 279.6 & 15.0 & 304.5 & 138.6 & 276.7 & 2.3 & NA \\
\hline $\begin{array}{l}\text { 12ZA93- } \\
100\end{array}$ & 106 & 1401 & 0.7 & 19.10 & 11.5 & 0.32 & 11.8 & 0.0441 & 2.8 & 0.24 & 278.2 & 7.6 & 280.6 & 29.0 & 300.5 & 262.9 & 278.2 & 7.6 & NA \\
\hline $\begin{array}{l}\text { 12ZA93- } \\
46\end{array}$ & 243 & 23337 & 2.0 & 19.04 & 3.6 & 0.32 & 3.8 & 0.0442 & 1.3 & 0.34 & 278.6 & 3.5 & 281.8 & 9.3 & 308.4 & 81.3 & 278.6 & 3.5 & NA \\
\hline $\begin{array}{l}\text { 12ZA93- } \\
19\end{array}$ & 480 & 2119 & 0.7 & 18.76 & 5.6 & 0.33 & 6.1 & 0.0448 & 2.3 & 0.38 & 282.7 & 6.3 & 289.2 & 15.3 & 342.0 & 127.1 & 282.7 & 6.3 & NA \\
\hline $\begin{array}{l}\text { 12ZA93- } \\
88\end{array}$ & 344 & 3401 & 1.2 & 18.81 & 5.6 & 0.34 & 5.8 & 0.0459 & 1.7 & 0.30 & 289.6 & 4.9 & 294.8 & 14.9 & 336.4 & 125.9 & 289.6 & 4.9 & NA \\
\hline $\begin{array}{l}\text { 12ZA93- } \\
71\end{array}$ & 177 & 20276 & 1.2 & 19.13 & 5.5 & 0.34 & 5.7 & 0.0471 & 1.1 & 0.19 & 296.6 & 3.1 & 296.7 & 14.5 & 296.9 & 126.7 & 296.6 & 3.1 & NA \\
\hline $\begin{array}{l}\text { 12ZA93- } \\
80\end{array}$ & 66 & 2950 & 1.3 & 17.07 & 18.2 & 0.41 & 18.3 & 0.0512 & 1.6 & 0.09 & 321.7 & 4.9 & 351.2 & 54.3 & 551.2 & 400.5 & 321.7 & 4.9 & NA \\
\hline $\begin{array}{l}\text { 12ZA93- } \\
63\end{array}$ & 280 & 41750 & 7.2 & 17.20 & 3.1 & 0.51 & 4.5 & 0.0634 & 3.2 & 0.72 & 396.1 & 12.5 & 417.1 & 15.4 & 535.2 & 68.2 & 396.1 & 12.5 & NA \\
\hline $\begin{array}{l}\text { 12ZA93- } \\
20\end{array}$ & 297 & 75183 & 1.5 & 17.40 & 2.1 & 0.57 & 2.3 & 0.0717 & 1.0 & 0.41 & 446.4 & 4.2 & 456.8 & 8.6 & 509.6 & 46.9 & 446.4 & 4.2 & 87.6 \\
\hline $\begin{array}{l}\text { 12ZA93- } \\
21\end{array}$ & 117 & 31865 & 0.8 & 17.41 & 7.0 & 0.58 & 7.7 & 0.0732 & 3.3 & 0.43 & 455.2 & 14.6 & 464.2 & 28.8 & 509.0 & 153.7 & 455.2 & 14.6 & 89.4 \\
\hline $\begin{array}{l}\text { 12ZA93- } \\
41\end{array}$ & 150 & 44217 & 2.8 & 18.47 & 2.6 & 0.56 & 3.4 & 0.0748 & 2.2 & 0.65 & 464.8 & 10.0 & 450.2 & 12.5 & 376.6 & 58.7 & 464.8 & 10.0 & 123.4 \\
\hline $\begin{array}{l}\text { 12ZA93- } \\
9\end{array}$ & 271 & 91208 & 1.4 & 17.33 & 2.0 & 0.60 & 3.5 & 0.0749 & 2.9 & 0.82 & 465.6 & 13.1 & 474.7 & 13.4 & 519.0 & 44.1 & 465.6 & 13.1 & 89.7 \\
\hline
\end{tabular}




\begin{tabular}{|c|c|c|c|c|c|c|c|c|c|c|c|c|c|c|c|c|c|c|c|}
\hline Analysis & $\mathrm{U}$ & $206 \mathrm{~Pb}$ & $\mathrm{U} / \mathrm{Th}$ & $206 \mathrm{~Pb}^{*}$ & \pm & $207 \mathrm{~Pb}^{*}$ & \pm & $206 \mathrm{~Pb}^{*}$ & \pm & error & $206 \mathrm{~Pb}^{*}$ & \pm & $207 \mathrm{~Pb}^{*}$ & \pm & $206 \mathrm{~Pb}^{*}$ & \pm & $\begin{array}{c}\text { Best } \\
\text { age }\end{array}$ & \pm & Conc \\
\hline & (ppm) & $204 \mathrm{~Pb}$ & & $207 \mathrm{~Pb}^{*}$ & (\%) & $235 \mathrm{U}^{*}$ & (\%) & $238 \mathrm{U}$ & (\%) & corr. & $238 \mathrm{U}^{*}$ & (Ma) & $235 \mathrm{U}$ & (Ma) & $207 \mathrm{~Pb}^{*}$ & (Ma) & (Ma) & (Ma) & $(\%)$ \\
\hline $\begin{array}{l}\text { 12ZA93- } \\
96\end{array}$ & 56 & 11867 & 1.2 & 21.26 & 26.5 & 0.49 & 27.0 & 0.0751 & 4.9 & 0.18 & 466.6 & 22.3 & 402.8 & 90.0 & 51.4 & 643.4 & 466.6 & 22.3 & 907.3 \\
\hline $\begin{array}{l}\text { 12ZA93- } \\
56\end{array}$ & 342 & 63692 & 1.1 & 17.75 & 1.4 & 0.59 & 4.3 & 0.0757 & 4.1 & 0.95 & 470.1 & 18.6 & 469.3 & 16.2 & 465.5 & 30.5 & 470.1 & 18.6 & 101.0 \\
\hline $\begin{array}{l}12 \text { ZA93- } \\
33\end{array}$ & 273 & 5376 & 0.9 & 17.17 & 6.4 & 0.61 & 7.0 & 0.0761 & 3.0 & 0.42 & 472.8 & 13.6 & 484.1 & 27.1 & 538.2 & 139.4 & 472.8 & 13.6 & 87.8 \\
\hline $\begin{array}{l}\text { 12ZA93- } \\
48\end{array}$ & 278 & 75186 & 2.9 & 17.76 & 1.6 & 0.59 & 2.8 & 0.0763 & 2.3 & 0.82 & 473.7 & 10.4 & 472.0 & 10.4 & 463.9 & 35.0 & 473.7 & 10.4 & 102.1 \\
\hline $\begin{array}{l}12 \text { ZA93- } \\
18\end{array}$ & 140 & 23750 & 2.3 & 18.00 & 2.4 & 0.58 & 2.6 & 0.0763 & 0.9 & 0.35 & 474.2 & 4.1 & 467.4 & 9.7 & 434.1 & 54.1 & 474.2 & 4.1 & 109.2 \\
\hline $\begin{array}{l}\text { 12ZA93- } \\
47\end{array}$ & 316 & 38417 & 1.5 & 17.52 & 1.5 & 0.60 & 2.5 & 0.0764 & 2.0 & 0.80 & 474.8 & 9.1 & 478.1 & 9.5 & 494.3 & 33.3 & 474.8 & 9.1 & 96.1 \\
\hline $\begin{array}{l}\text { 12ZA93- } \\
50\end{array}$ & 339 & 98352 & 1.7 & 17.75 & 1.5 & 0.60 & 2.3 & 0.0768 & 1.7 & 0.76 & 476.7 & 8.0 & 474.7 & 8.7 & 465.1 & 33.0 & 476.7 & 8.0 & 102.5 \\
\hline $\begin{array}{l}\text { 12ZA93- } \\
94\end{array}$ & 541 & 75117 & 3.4 & 16.44 & 3.4 & 0.64 & 4.6 & 0.0769 & 3.2 & 0.69 & 477.3 & 14.6 & 505.1 & 18.5 & 632.9 & 72.7 & 477.3 & 14.6 & 75.4 \\
\hline $\begin{array}{l}\text { 12ZA93- } \\
78\end{array}$ & 124 & 14610 & 1.6 & 17.47 & 3.6 & 0.61 & 3.9 & 0.0772 & 1.5 & 0.39 & 479.2 & 7.1 & 483.0 & 15.0 & 500.9 & 79.2 & 479.2 & 7.1 & 95.7 \\
\hline $\begin{array}{l}\text { 12ZA93- } \\
61\end{array}$ & 53 & 14311 & 1.6 & 18.76 & 10.4 & 0.57 & 10.8 & 0.0772 & 2.7 & 0.25 & 479.7 & 12.5 & 456.5 & 39.7 & 341.7 & 236.8 & 479.7 & 12.5 & 140.4 \\
\hline $\begin{array}{l}\text { 12ZA93- } \\
12\end{array}$ & 261 & 59577 & 1.8 & 17.50 & 2.1 & 0.61 & 2.7 & 0.0773 & 1.6 & 0.62 & 480.1 & 7.6 & 483.0 & 10.2 & 496.7 & 46.1 & 480.1 & 7.6 & 96.6 \\
\hline $\begin{array}{l}\text { 12ZA93- } \\
52\end{array}$ & 166 & 29631 & 3.1 & 17.50 & 2.7 & 0.62 & 3.9 & 0.0789 & 2.7 & 0.71 & 489.8 & 12.8 & 491.2 & 15.0 & 497.6 & 60.4 & 489.8 & 12.8 & 98.4 \\
\hline $\begin{array}{l}\text { 12ZA93- } \\
25\end{array}$ & 395 & 103108 & 0.9 & 17.08 & 1.5 & 0.68 & 2.9 & 0.0848 & 2.5 & 0.85 & 524.8 & 12.4 & 529.6 & 11.9 & 550.4 & 33.1 & 524.8 & 12.4 & 95.4 \\
\hline $\begin{array}{l}\text { 12ZA93- } \\
32\end{array}$ & 571 & 13272 & 1.7 & 17.01 & 0.9 & 0.71 & 2.5 & 0.0873 & 2.3 & 0.93 & 539.5 & 12.1 & 543.2 & 10.6 & 558.8 & 20.1 & 539.5 & 12.1 & 96.5 \\
\hline $\begin{array}{l}\text { 12ZA93- } \\
60\end{array}$ & 194 & 15461 & 1.9 & 16.85 & 2.3 & 0.73 & 3.3 & 0.0895 & 2.4 & 0.73 & 552.7 & 12.8 & 558.0 & 14.2 & 579.8 & 48.9 & 552.7 & 12.8 & 95.3 \\
\hline $\begin{array}{l}\text { 12ZA93- } \\
15\end{array}$ & 331 & 87121 & 4.1 & 16.88 & 1.3 & 0.73 & 2.1 & 0.0899 & 1.6 & 0.77 & 555.0 & 8.4 & 559.3 & 8.8 & 576.4 & 28.4 & 555.0 & 8.4 & 96.3 \\
\hline $\begin{array}{l}\text { 12ZA93- } \\
64\end{array}$ & 253 & 55523 & 5.6 & 17.18 & 2.4 & 0.73 & 3.2 & 0.0906 & 2.2 & 0.68 & 558.9 & 11.7 & 554.8 & 13.7 & 538.0 & 51.4 & 558.9 & 11.7 & 103.9 \\
\hline $\begin{array}{l}\text { 12ZA93- } \\
58\end{array}$ & 153 & 10565 & 1.3 & 16.73 & 3.3 & 0.75 & 4.4 & 0.0910 & 2.9 & 0.66 & 561.3 & 15.8 & 568.1 & 19.4 & 595.4 & 72.5 & 561.3 & 15.8 & 94.3 \\
\hline $\begin{array}{l}\text { 12ZA93- } \\
51\end{array}$ & 414 & 184452 & 1.3 & 16.65 & 1.5 & 0.80 & 2.3 & 0.0962 & 1.7 & 0.75 & 591.9 & 9.6 & 594.9 & 10.2 & 606.3 & 32.8 & 591.9 & 9.6 & 97.6 \\
\hline $\begin{array}{l}\text { 12ZA93- } \\
35\end{array}$ & 72 & 40338 & 1.8 & 16.75 & 2.7 & 0.82 & 5.2 & 0.1000 & 4.4 & 0.85 & 614.6 & 26.0 & 609.9 & 23.8 & 592.3 & 58.3 & 614.6 & 26.0 & 103.8 \\
\hline $\begin{array}{l}\text { 12ZA93- } \\
11\end{array}$ & 364 & 181662 & 1.6 & 16.09 & 1.4 & 0.87 & 3.7 & 0.1020 & 3.4 & 0.92 & 626.0 & 20.3 & 637.6 & 17.4 & 678.8 & 30.0 & 626.0 & 20.3 & 92.2 \\
\hline $\begin{array}{l}\text { 12ZA93- } \\
76\end{array}$ & 289 & 127733 & 1.5 & 16.24 & 1.8 & 0.89 & 1.8 & 0.1053 & 0.3 & 0.17 & 645.2 & 1.9 & 648.5 & 8.8 & 660.0 & 38.6 & 645.2 & 1.9 & 97.8 \\
\hline $\begin{array}{l}\text { 12ZA93- } \\
36\end{array}$ & 75 & 45191 & 2.6 & 15.89 & 2.9 & 0.92 & 7.8 & 0.1055 & 7.2 & 0.93 & 646.5 & 44.4 & 659.9 & 37.8 & 705.8 & 61.8 & 646.5 & 44.4 & 91.6 \\
\hline $\begin{array}{l}\text { 12ZA93- } \\
75\end{array}$ & 418 & 162164 & 14.6 & 16.03 & 1.1 & 0.91 & 1.4 & 0.1057 & 0.9 & 0.60 & 647.8 & 5.2 & 656.7 & 6.9 & 687.2 & 24.4 & 647.8 & 5.2 & 94.3 \\
\hline $\begin{array}{l}\text { 12ZA93- } \\
44\end{array}$ & 346 & 6865 & 8.1 & 15.25 & 2.3 & 0.96 & 5.9 & 0.1060 & 5.4 & 0.92 & 649.7 & 33.5 & 682.7 & 29.2 & 793.3 & 47.6 & 649.7 & 33.5 & 81.9 \\
\hline $\begin{array}{l}\text { 12ZA93- } \\
54\end{array}$ & 459 & 276391 & 3.5 & 16.29 & 0.6 & 0.90 & 2.1 & 0.1063 & 2.0 & 0.96 & 651.4 & 12.4 & 651.6 & 10.0 & 652.3 & 12.8 & 651.4 & 12.4 & 99.9 \\
\hline $\begin{array}{l}\text { 12ZA93- } \\
17\end{array}$ & 577 & 146639 & 9.0 & 16.26 & 0.5 & 0.90 & 2.4 & 0.1065 & 2.4 & 0.98 & 652.5 & 14.8 & 653.6 & 11.8 & 657.3 & 11.5 & 652.5 & 14.8 & 99.3 \\
\hline $\begin{array}{l}\text { 12ZA93- } \\
95\end{array}$ & 78 & 33822 & 1.5 & 16.40 & 4.9 & 0.92 & 5.3 & 0.1093 & 1.9 & 0.37 & 668.5 & 12.3 & 661.7 & 25.6 & 638.4 & 105.1 & 668.5 & 12.3 & 104.7 \\
\hline $\begin{array}{l}\text { 12ZA93- } \\
34\end{array}$ & 304 & 238260 & 1.1 & 16.07 & 0.6 & 0.99 & 2.4 & 0.1149 & 2.4 & 0.97 & 701.1 & 15.7 & 696.7 & 12.3 & 682.3 & 12.7 & 701.1 & 15.7 & 102.8 \\
\hline $\begin{array}{l}\text { 12ZA93- } \\
72\end{array}$ & 170 & 4014 & 2.1 & 14.43 & 2.9 & 1.21 & 3.3 & 0.1264 & 1.7 & 0.50 & 767.1 & 11.9 & 804.0 & 18.3 & 907.8 & 58.8 & 767.1 & 11.9 & 84.5 \\
\hline $\begin{array}{l}\text { 12ZA93- } \\
27\end{array}$ & 184 & 114060 & 3.2 & 14.24 & 2.3 & 1.22 & 3.8 & 0.1264 & 3.0 & 0.80 & 767.6 & 21.9 & 811.7 & 21.3 & 934.8 & 47.3 & 767.6 & 21.9 & 82.1 \\
\hline $\begin{array}{l}\text { 12ZA93- } \\
2\end{array}$ & 397 & 134529 & 2.1 & 14.15 & 0.8 & 1.43 & 2.2 & 0.1471 & 2.0 & 0.92 & 884.5 & 16.4 & 902.7 & 12.9 & 947.6 & 17.3 & 947.6 & 17.3 & 93.3 \\
\hline $\begin{array}{l}\text { 12ZA93- } \\
6\end{array}$ & 129 & 61639 & 2.6 & 14.02 & 1.8 & 1.51 & 3.1 & 0.1539 & 2.5 & 0.82 & 922.5 & 21.8 & 935.8 & 19.0 & 967.0 & 36.7 & 967.0 & 36.7 & 95.4 \\
\hline $\begin{array}{l}\text { 12ZA93- } \\
13\end{array}$ & 166 & 69585 & 2.7 & 13.99 & 1.8 & 1.57 & 3.9 & 0.1593 & 3.5 & 0.89 & 953.0 & 31.0 & 958.5 & 24.3 & 971.2 & 35.9 & 971.2 & 35.9 & 98.1 \\
\hline $\begin{array}{l}\text { 12ZA93- } \\
79\end{array}$ & 120 & 12389 & 2.8 & 13.79 & 2.0 & 1.63 & 2.4 & 0.1632 & 1.3 & 0.55 & 974.6 & 11.9 & 982.7 & 15.0 & 1000.8 & 40.3 & 1000.8 & 40.3 & 97.4 \\
\hline $\begin{array}{l}\text { 12ZA93- } \\
37\end{array}$ & 198 & 66641 & 2.2 & 13.76 & 1.2 & 1.71 & 3.8 & 0.1703 & 3.6 & 0.95 & 1013.7 & 33.9 & 1010.9 & 24.3 & 1004.9 & 23.6 & 1004.9 & 23.6 & 100.9 \\
\hline $\begin{array}{l}\text { 12ZA93- } \\
84\end{array}$ & 226 & 58658 & 8.8 & 13.75 & 0.9 & 1.57 & 1.7 & 0.1562 & 1.5 & 0.85 & 935.8 & 12.8 & 957.2 & 10.8 & 1006.6 & 18.8 & 1006.6 & 18.8 & 93.0 \\
\hline $\begin{array}{l}\text { 12ZA93- } \\
10\end{array}$ & 151 & 104672 & 2.6 & 13.67 & 1.0 & 1.71 & 3.6 & 0.1696 & 3.4 & 0.96 & 1010.0 & 31.9 & 1012.8 & 22.8 & 1018.7 & 21.0 & 1018.7 & 21.0 & 99.1 \\
\hline $\begin{array}{l}\text { 12ZA93- } \\
97\end{array}$ & 152 & 110859 & 2.8 & 13.64 & 0.9 & 1.76 & 3.2 & 0.1740 & 3.1 & 0.96 & 1034.4 & 29.5 & 1030.6 & 20.9 & 1022.5 & 19.1 & 1022.5 & 19.1 & 101.2 \\
\hline
\end{tabular}




\begin{tabular}{|c|c|c|c|c|c|c|c|c|c|c|c|c|c|c|c|c|c|c|c|}
\hline Analysis & $\mathrm{U}$ & $206 \mathrm{~Pb}$ & $\mathrm{U} / \mathrm{Th}$ & $206 \mathrm{~Pb}^{*}$ & \pm & $207 \mathrm{~Pb}^{*}$ & \pm & $206 \mathrm{~Pb}^{*}$ & \pm & error & $206 \mathrm{~Pb}^{*}$ & \pm & $207 \mathrm{~Pb}^{*}$ & \pm & $206 \mathrm{~Pb}^{*}$ & \pm & $\begin{array}{l}\text { Best } \\
\text { age }\end{array}$ & \pm & Conc \\
\hline & $(\mathrm{ppm})$ & $204 \mathrm{~Pb}$ & & $207 \mathrm{~Pb}^{*}$ & $(\%)$ & $235 \mathrm{U}^{*}$ & $(\%)$ & $238 \mathrm{U}$ & $(\%)$ & corr. & $238 \mathrm{U}^{*}$ & (Ma) & $235 \mathrm{U}$ & (Ma) & $207 \mathrm{~Pb}^{*}$ & (Ma) & (Ma) & (Ma) & (\%) \\
\hline $\begin{array}{l}\text { 12ZA93- } \\
49\end{array}$ & 189 & 23047 & 2.7 & 13.62 & 2.7 & 1.60 & 5.6 & 0.1582 & 4.9 & 0.88 & 947.0 & 43.0 & 971.1 & 34.9 & 1026.2 & 54.5 & 1026.2 & 54.5 & 92.3 \\
\hline $\begin{array}{l}\text { 12ZA93- } \\
82\end{array}$ & 144 & 55834 & 1.2 & 13.53 & 1.5 & 1.81 & 1.7 & 0.1774 & 0.7 & 0.41 & 1053.0 & 6.7 & 1048.5 & 10.9 & 1039.0 & 30.5 & 1039.0 & 30.5 & 101.3 \\
\hline $\begin{array}{l}\text { 12ZA93- } \\
93\end{array}$ & 503 & 107912 & 1.9 & 13.51 & 0.7 & 1.71 & 2.3 & 0.1678 & 2.2 & 0.95 & 999.7 & 20.6 & 1013.1 & 14.9 & 1042.0 & 14.3 & 1042.0 & 14.3 & 95.9 \\
\hline $\begin{array}{l}\text { 12ZA93- } \\
28\end{array}$ & 63 & 24695 & 2.9 & 13.48 & 2.0 & 1.72 & 2.5 & 0.1684 & 1.5 & 0.59 & 1003.1 & 13.7 & 1016.7 & 16.0 & 1046.1 & 40.3 & 1046.1 & 40.3 & 95.9 \\
\hline $\begin{array}{l}\text { 12ZA93- } \\
53\end{array}$ & 282 & 199379 & 1.8 & 13.42 & 0.9 & 1.79 & 1.6 & 0.1742 & 1.3 & 0.82 & 1035.3 & 12.3 & 1041.8 & 10.2 & 1055.4 & 18.2 & 1055.4 & 18.2 & 98.1 \\
\hline $\begin{array}{l}\text { 12ZA93- } \\
29\end{array}$ & 210 & 53895 & 2.3 & 13.26 & 0.6 & 1.90 & 3.1 & 0.1822 & 3.1 & 0.98 & 1079.2 & 30.5 & 1079.6 & 20.8 & 1080.3 & 12.5 & 1080.3 & 12.5 & 99.9 \\
\hline $\begin{array}{l}\text { 12ZA93- } \\
30\end{array}$ & 326 & 157024 & 3.5 & 13.21 & 0.7 & 1.81 & 1.0 & 0.1733 & 0.7 & 0.72 & 1030.3 & 7.0 & 1048.6 & 6.7 & 1087.1 & 14.1 & 1087.1 & 14.1 & 94.8 \\
\hline $\begin{array}{l}\text { 12ZA93- } \\
86\end{array}$ & 182 & 142258 & 5.9 & 13.15 & 1.0 & 1.89 & 2.2 & 0.1799 & 2.0 & 0.90 & 1066.2 & 19.6 & 1076.1 & 14.7 & 1096.2 & 19.1 & 1096.2 & 19.1 & 97.3 \\
\hline $\begin{array}{l}\text { 12ZA93- } \\
98\end{array}$ & 307 & 92268 & 1.4 & 13.10 & 0.9 & 1.97 & 2.5 & 0.1871 & 2.3 & 0.93 & 1105.9 & 23.5 & 1105.0 & 16.7 & 1103.3 & 17.6 & 1103.3 & 17.6 & 100.2 \\
\hline $\begin{array}{l}\text { 12ZA93- } \\
81\end{array}$ & 145 & 115107 & 1.3 & 12.86 & 1.5 & 2.06 & 1.9 & 0.1925 & 1.1 & 0.57 & 1134.8 & 11.1 & 1136.9 & 12.8 & 1141.0 & 30.5 & 1141.0 & 30.5 & 99.5 \\
\hline $\begin{array}{l}\text { 12ZA93- } \\
39\end{array}$ & 141 & 61276 & 3.8 & 12.79 & 1.1 & 2.08 & 2.4 & 0.1932 & 2.1 & 0.89 & 1138.8 & 22.2 & 1143.1 & 16.5 & 1151.3 & 22.1 & 1151.3 & 22.1 & 98.9 \\
\hline $\begin{array}{l}\text { 12ZA93- } \\
45\end{array}$ & 127 & 61841 & 2.2 & 12.74 & 0.8 & 2.15 & 1.7 & 0.1990 & 1.5 & 0.87 & 1170.2 & 15.6 & 1166.2 & 11.6 & 1158.9 & 16.3 & 1158.9 & 16.3 & 101.0 \\
\hline $\begin{array}{l}\text { 12ZA93- } \\
67\end{array}$ & 296 & 158469 & 2.7 & 11.54 & 0.6 & 2.90 & 1.5 & 0.2430 & 1.4 & 0.92 & 1402.4 & 17.2 & 1382.5 & 11.2 & 1352.1 & 11.2 & 1352.1 & 11.2 & 103.7 \\
\hline $\begin{array}{l}\text { 12ZA93- } \\
38\end{array}$ & 78 & 108380 & 1.3 & 11.49 & 1.6 & 2.76 & 2.6 & 0.2303 & 2.0 & 0.79 & 1336.3 & 24.4 & 1345.6 & 19.2 & 1360.4 & 30.5 & 1360.4 & 30.5 & 98.2 \\
\hline $\begin{array}{l}\text { 12ZA93- } \\
69\end{array}$ & 77 & 28139 & 2.2 & 11.27 & 1.3 & 3.02 & 6.6 & 0.2465 & 6.5 & 0.98 & 1420.3 & 82.7 & 1411.5 & 50.5 & 1398.2 & 24.5 & 1398.2 & 24.5 & 101.6 \\
\hline $\begin{array}{l}\text { 12ZA93- } \\
70\end{array}$ & 109 & 49492 & 2.0 & 10.16 & 0.8 & 3.75 & 1.0 & 0.2764 & 0.5 & 0.54 & 1573.4 & 7.3 & 1582.2 & 7.7 & 1594.0 & 15.1 & 1594.0 & 15.1 & 98.7 \\
\hline $\begin{array}{l}\text { 12ZA93- } \\
83\end{array}$ & 127 & 76756 & 2.5 & 9.85 & 1.1 & 3.56 & 2.6 & 0.2544 & 2.4 & 0.91 & 1461.4 & 31.2 & 1540.7 & 20.8 & 1651.3 & 20.0 & 1651.3 & 20.0 & 88.5 \\
\hline $\begin{array}{l}\text { 12ZA93- } \\
66\end{array}$ & 201 & 29324 & 6.7 & 8.74 & 0.4 & 5.23 & 2.2 & 0.3314 & 2.2 & 0.98 & 1845.3 & 34.9 & 1857.8 & 18.9 & 1871.7 & 8.0 & 1871.7 & 8.0 & 98.6 \\
\hline $\begin{array}{l}\text { 12ZA93- } \\
43\end{array}$ & 236 & 45147 & 1.6 & 7.67 & 0.5 & 6.74 & 3.8 & 0.3746 & 3.7 & 0.99 & 2050.8 & 65.8 & 2077.3 & 33.4 & 2103.7 & 8.2 & 2103.7 & 8.2 & 97.5 \\
\hline $\begin{array}{l}\text { 12ZA93- } \\
40\end{array}$ & 140 & 209045 & 1.6 & 5.37 & 0.6 & 13.85 & 7.8 & 0.5393 & 7.8 & 1.00 & 2780.4 & 175 & 2739.3 & 73.8 & 2709.2 & 9.3 & 2709.2 & 9.3 & 102.6 \\
\hline
\end{tabular}




\section{Appendix B: Ecca/Beaufort Sandstone Composition}

\begin{tabular}{|c|c|c|c|c|c|c|c|c|c|c|c|}
\hline Sample & Qt & Qm & Qp & $\mathbf{F t}$ & Fpu & Fpt & Fk & Lt & Ls & $\mathbf{L v}$ & $\mathbf{L m}$ \\
\hline \multicolumn{12}{|l|}{ 12ZA13 } \\
\hline Total & 230 & 201 & 35 & 88 & 48 & 36 & 4 & 82 & 74 & 5 & 3 \\
\hline Total/400 & 0.575 & 0.5025 & 0.0875 & 0.22 & 0.12 & 0.09 & 0.01 & 0.205 & 0.185 & 0.01 & 0.008 \\
\hline Relative \% & 57.5 & 50.25 & 8.75 & 22 & 12 & 9 & 1 & 20.5 & 18.5 & 1.25 & 0.75 \\
\hline 13ZA68 & Qt & Qm & Qp & Ft & Fpu & Fpt & Fk & Lt & Ls & $\mathbf{L v}$ & $\mathbf{L m}$ \\
\hline Total & 191 & 159 & 32 & 66 & 35 & 26 & 5 & 143 & 125 & 16 & 2 \\
\hline Total $/ 400$ & 0.4775 & 0.3975 & 0.08 & 0.165 & 0.0875 & 0.065 & 0.0125 & 0.358 & 0.3125 & 0.04 & 0.005 \\
\hline Relative \% & 47.75 & 39.75 & 8 & 16.5 & 8.75 & 6.5 & 1.25 & 35.75 & 31.25 & 4 & 0.5 \\
\hline 13ZA71 & Qt & Qm & Qp & Ft & Fpu & Fpt & Fk & $\mathbf{L t}$ & Ls & $\mathbf{L v}$ & $\mathbf{L m}$ \\
\hline Total & 215 & 199 & 16 & 85 & 53 & 32 & 5 & 101 & 85 & 11 & 4 \\
\hline Total $/ 400$ & 0.5375 & 0.4975 & 0.04 & 0.2125 & 0.1325 & 0.08 & 0.0125 & 0.253 & 0.2125 & 0.03 & 0.01 \\
\hline Relative \% & 53.75 & 49.75 & 4 & 21.25 & 13.25 & 8 & 1.25 & 25.25 & 22.25 & 2.75 & 1 \\
\hline 13ZA72 & Qt & Qm & Qp & Ft & Fpu & Fpt & $\mathbf{F k}$ & Lt & Ls & Lv & $\mathbf{L m}$ \\
\hline Total & 236 & 206 & 30 & 106 & 43 & 55 & 8 & 58 & 37 & 17 & 4 \\
\hline Total $/ 400$ & 0.59 & 0.515 & 0.075 & 0.265 & 0.1075 & 0.1375 & 0.02 & 0.145 & 0.0925 & 0.04 & 0.01 \\
\hline Relative \% & 59 & 51.5 & 7.5 & 26.5 & 10.75 & 13.75 & 2 & 14.5 & 9.25 & 4.25 & 1 \\
\hline 13ZA73 & Qt & Qm & Qp & Ft & Fpu & Fpt & Fk & Lt & Ls & $\mathbf{L v}$ & Lm \\
\hline Total & 228 & 193 & 35 & 76 & 49 & 24 & 3 & 96 & 65 & 27 & 4 \\
\hline Total $/ 400$ & 0.57 & 0.4825 & 0.0875 & 0.19 & 0.1225 & 0.06 & 0.0075 & 0.24 & 0.1625 & 0.07 & 0.01 \\
\hline Relative \% & 57 & 48.25 & 8.75 & 19 & 12.25 & 6 & 0.75 & 24 & 16.25 & 6.75 & 1 \\
\hline 13ZA74 & Qt & Qm & Qp & Ft & Fpu & Fpt & $\mathbf{F k}$ & Lt & Ls & $\mathbf{L v}$ & $\mathbf{L m}$ \\
\hline Total & 188 & 165 & 23 & 117 & 54 & 60 & 3 & 95 & 71 & 22 & 2 \\
\hline Total $/ 400$ & 0.47 & 0.4125 & 0.0575 & 0.2925 & 0.135 & 0.15 & 0.0075 & 0.238 & 0.1775 & 0.06 & 0.005 \\
\hline Relative \% & 47 & 41.25 & 5.75 & 29.25 & 13.5 & 15 & 0.75 & 23.75 & 17.75 & 5.5 & 0.5 \\
\hline 13ZA78 & Qt & Qm & Qp & Ft & Fpu & Fpt & $\mathbf{F k}$ & Lt & Ls & $\mathbf{L v}$ & $\mathbf{L m}$ \\
\hline Total & 168 & 154 & 14 & 125 & 45 & 78 & 2 & 107 & 73 & 30 & 4 \\
\hline Total $/ 400$ & 0.42 & 0.385 & 0.035 & 0.3125 & 0.1125 & 0.195 & 0.005 & 0.268 & 0.1825 & 0.08 & 0.01 \\
\hline Relative \% & 42 & 38.5 & 3.5 & 31.25 & 11.25 & 19.5 & 0.5 & 26.75 & 18.25 & 7.5 & 1 \\
\hline 12ZA26 & Qt & Qm & Qp & Ft & Fpu & Fpt & Fk & Lt & Ls & $\mathbf{L v}$ & $\mathbf{L m}$ \\
\hline Total & 180 & 144 & 36 & 104 & 58 & 41 & 5 & 116 & 107 & 6 & 3 \\
\hline Total $/ 400$ & 0.45 & 0.36 & 0.09 & 0.26 & 0.145 & 0.1025 & 0.0125 & 0.29 & 0.2675 & 0.02 & 0.008 \\
\hline Relative \% & 45 & 36 & 9 & 26 & 14.5 & 10.25 & 1.25 & 29 & 26.75 & 1.5 & 0.75 \\
\hline
\end{tabular}




\begin{tabular}{|c|c|c|c|c|c|c|c|c|c|c|c|}
\hline 13ZA86 & Qt & Qm & Qp & $\mathbf{F t}$ & Fpu & Fpt & Fk & Lt & Ls & $\mathbf{L v}$ & $\mathbf{L m}$ \\
\hline Total & 157 & 145 & 12 & 126 & 65 & 59 & 2 & 117 & 81 & 30 & 6 \\
\hline Total $/ 400$ & 0.3925 & 0.3625 & 0.03 & 0.315 & 0.1625 & 0.1475 & 0.005 & 0.293 & 0.2025 & 0.08 & 0.015 \\
\hline Relative \% & 39.25 & 36.25 & 3 & 31.5 & 16.25 & 14.75 & 0.5 & 29.25 & 20.25 & 7.5 & 1.5 \\
\hline 13ZA87 & Qt & Qm & Qp & Ft & Fpu & Fpt & Fk & $\mathbf{L t}$ & Ls & Lv & $\mathbf{L m}$ \\
\hline Total & 172 & 155 & 17 & 115 & 68 & 47 & 1 & 113 & 90 & 18 & 5 \\
\hline Total $/ 400$ & 0.43 & 0.3875 & 0.0425 & 0.2875 & 0.17 & 0.1175 & 0.0025 & 0.283 & 0.225 & 0.05 & 0.013 \\
\hline Relative \% & 43 & 38.75 & 4.25 & 28.75 & 17 & 11.75 & 0.25 & 28.25 & 22.5 & 4.5 & 1.25 \\
\hline 13ZA88 & Qt & Qm & Qp & $\mathbf{F t}$ & Fpu & Fpt & Fk & Lt & Ls & $\mathbf{L v}$ & $\mathbf{L m}$ \\
\hline Total & 186 & 173 & 13 & 94 & 51 & 40 & 3 & 120 & 98 & 22 & 0 \\
\hline Total $/ 400$ & 0.465 & 0.4325 & 0.0325 & 0.235 & 0.1275 & 0.1 & 0.0075 & 0.3 & 0.245 & 0.06 & 0 \\
\hline Relative \% & 46.5 & 43.25 & 3.25 & 23.5 & 12.75 & 10 & 0.75 & 30 & 24.5 & 5.5 & 0 \\
\hline 13ZA90 & Qt & Qm & Qp & Ft & Fpu & Fpt & Fk & Lt & Ls & Lv & Lm \\
\hline Total & 183 & 162 & 21 & 137 & 54 & 80 & 3 & 80 & 71 & 8 & 1 \\
\hline Total/400 & 0.4575 & 0.405 & 0.0525 & 0.3425 & 0.135 & 0.2 & 0.0075 & 0.2 & 0.1775 & 0.02 & 0.003 \\
\hline Relative \% & 45.75 & 40.5 & 5.25 & 34.25 & 13.5 & 20 & 0.75 & 20 & 17.75 & 2 & 0.25 \\
\hline 13ZA91 & Qt & Qm & Qp & $\mathbf{F t}$ & Fpu & Fpt & Fk & Lt & Ls & Lv & $\mathbf{L m}$ \\
\hline Total & 156 & 142 & 14 & 146 & 79 & 61 & 6 & 98 & 84 & 10 & 4 \\
\hline Total/400 & 0.39 & 0.355 & 0.035 & 0.365 & 0.1975 & 0.1525 & 0.015 & 0.245 & 0.21 & 0.03 & 0.01 \\
\hline Relative \% & 39 & 35.5 & 3.5 & 36.5 & 19.75 & 15.25 & 1.5 & 24.5 & 21 & 2.5 & 1 \\
\hline 13ZA92 & Qt & Qm & Qp & Ft & Fpu & Fpt & Fk & Lt & Ls & Lv & $\mathbf{L m}$ \\
\hline Total & 168 & 151 & 17 & 123 & 73 & 45 & 5 & 109 & 88 & 20 & 1 \\
\hline Total $/ 400$ & 0.42 & 0.3775 & 0.0425 & 0.3075 & 0.1825 & 0.1125 & 0.0125 & 0.273 & 0.22 & 0.05 & 0.003 \\
\hline Relative \% & 42 & 37.75 & 4.25 & 30.75 & 18.25 & 11.25 & 1.25 & 27.25 & 22 & 5 & 0.25 \\
\hline 13ZA93 & Qt & Qm & Qp & Ft & Fpu & Fpt & Fk & Lt & Ls & $\mathbf{L v}$ & $\mathbf{L m}$ \\
\hline Total & 213 & 176 & 37 & 93 & 58 & 32 & 3 & 94 & 83 & 11 & 0 \\
\hline Total $/ 400$ & 0.5325 & 0.44 & 0.0925 & 0.2325 & 0.145 & 0.08 & 0.0075 & 0.235 & 0.2075 & 0.03 & 0 \\
\hline Relative \% & 53.25 & 44 & 9.25 & 23.25 & 14.5 & 8 & 0.75 & 23.5 & 20.75 & 2.75 & 0 \\
\hline 09-BL-A1 & Qt & Qm & Qp & Ft & Fpu & Fpt & Fk & $\mathbf{L t}$ & Ls & $\mathbf{L v}$ & $\mathbf{L m}$ \\
\hline Total & 166 & 153 & 13 & 114 & 63 & 44 & 7 & 120 & 92 & 19 & 9 \\
\hline Total $/ 400$ & 0.415 & 0.3825 & 0.0325 & 0.285 & 0.1575 & 0.11 & 0.0175 & 0.3 & 0.23 & 0.05 & 0.023 \\
\hline Relative \% & 41.5 & 38.25 & 3.25 & 28.5 & 15.75 & 11 & 1.75 & 30 & 23 & 4.75 & 2.25 \\
\hline 09-BL-C1 & Qt & Qm & Qp & $\mathbf{F t}$ & Fpu & Fpt & Fk & $\mathbf{L t}$ & Ls & $\mathbf{L v}$ & $\mathbf{L m}$ \\
\hline Total & 173 & 161 & 12 & 90 & 67 & 20 & 3 & 137 & 99 & 34 & 4 \\
\hline Total $/ 400$ & 0.4325 & 0.4025 & 0.03 & 0.225 & 0.1675 & 0.05 & 0.0075 & 0.343 & 0.2475 & 0.09 & 0.01 \\
\hline Relative \% & 43.25 & 40.25 & 3 & 22.5 & 16.75 & 5 & 0.75 & 34.25 & 24.75 & 8.5 & 1 \\
\hline
\end{tabular}




\begin{tabular}{|l|r|r|r|r|r|r|r|r|r|r|r|} 
09-BL-E1 & Qt & Qm & Qp & Ft & Fpu & Fpt & Fk & Lt & Ls & Lv & Lm \\
\hline Total & 159 & 140 & 19 & 130 & 57 & 69 & 4 & 111 & 79 & 31 & 2 \\
\hline Total/400 & 0.3975 & 0.35 & 0.0475 & 0.325 & 0.1425 & 0.1725 & 0.01 & 0.278 & 0.1975 & 0.08 & 0.005 \\
\hline Relative \% & 39.75 & 35 & 4.75 & 32.5 & 14.25 & 17.25 & 1 & 27.75 & 19.75 & 7.75 & 0.5 \\
\hline
\end{tabular}

